\title{
Unconventional Gas Pipeline Right-of-Way Influence on Wildlife
}

Samuel C. Knopka

West Virginia University, sck0011@mix.wvu.edu

Follow this and additional works at: https://researchrepository.wvu.edu/etd

Part of the Terrestrial and Aquatic Ecology Commons

\section{Recommended Citation}

Knopka, Samuel C., "Unconventional Gas Pipeline Right-of-Way Influence on Wildlife" (2021). Graduate Theses, Dissertations, and Problem Reports. 8000.

https://researchrepository.wvu.edu/etd/8000

This Thesis is protected by copyright and/or related rights. It has been brought to you by the The Research Repository @ WVU with permission from the rights-holder(s). You are free to use this Thesis in any way that is permitted by the copyright and related rights legislation that applies to your use. For other uses you must obtain permission from the rights-holder(s) directly, unless additional rights are indicated by a Creative Commons license in the record and/ or on the work itself. This Thesis has been accepted for inclusion in WVU Graduate Theses, Dissertations, and Problem Reports collection by an authorized administrator of The Research Repository @ WVU. For more information, please contact researchrepository@mail.wvu.edu. 
Graduate Theses, Dissertations, and Problem Reports

2021

Unconventional Gas Pipeline Right-of-Way Influence on Wildlife

Samuel C. Knopka

Follow this and additional works at: https://researchrepository.wvu.edu/etd

Part of the Terrestrial and Aquatic Ecology Commons 
Unconventional Gas Pipeline Right-of-Way Influence on Wildlife

Samuel C. Knopka

Thesis submitted to the

Davis College of Agriculture, Natural Resources and Design

At West Virginia University

In partial fulfillment of the requirements

For the degree of

Master of Science

In

Wildlife and Fisheries Resources

John W. Edwards, Ph.D., Co-Chair

Shawn T. Grushecky, Ph.D., Co-Chair

Sheldon F. Owen, Ph.D.

Division of Forestry and Natural Resources

Morgantown, West Virginia

2021

Keywords: Fracking, natural gas, Pennsylvania, pipeline, pollinator, reclamation, ruffed grouse salamander, snake, unconventional

Copyright 2021 Samuel C. Knopka 


\section{Abstract \\ Unconventional Gas Pipeline Right-of-Way Influence on Wildlife}

Samuel C. Knopka

The development of horizontal drilling for natural gas in the Marcellus Shale in 2004 resulted in rapid exploitation of the play in the Appalachian Basin. This "unconventional" gas well drilling accesses resources deeper beneath the surface and allows for multiple wells to be co-located on a single well pad. This results in fewer, but larger, well pads on the landscape than traditional vertical wells. Pipelines are required to transport the volumes of gas produced by unconventional wells to production facilities and market. The effects of gathering pipelines, which transport gas from well pads to larger transport pipelines, are poorly studied compared to other types of disturbance.

This study evaluated how ruffed grouse (Bonasa umbellus), salamanders and snakes, and pollinators use pipeline right-of-ways (ROW) in a forested environment. Forested areas of Appalachia have undergone forest maturation and young forest habitat has declined. This habitat modification led to declines of ruffed grouse and pollinator species. Although ROWs increase forest fragmentation in large forest patches, they must be maintained as herbaceous vegetation to protect pipeline integrity. The goals of this research were to determine how variation in ROW reclamation influences wildlife use of these ROWs. Difference in use can provide recommendations that enable ROWs to provide the most benefit to these species, and if they could act as an analogue for early successional habitat.

All research was conducted on the Tiadaghton State Forest and Game Commission Game Lands 12, two land parcels in North-Central Pennsylvania managed by the state. These areas are heavily forested and contain a network of natural gas ROW that varied in age, width, and reclamation. Surveys from ruffed grouse and pollinators were conducted on these sites from May -August 2019 and 2020. Cover boards used to sample for reptiles and amphibians were deployed in summer 2019 and surveyed from May — August 2020.

Too few ruffed grouse were observed during surveys to perform analysis, but incidental observations of white-tailed deer (Odocoileus virginianus) and eastern wild turkeys (Meleagris gallopavo) on ROWs suggests that they provide some benefits to these species. Eastern red backed salamanders (Plethodon cinereus) were used as a case study to examine the effects of the ROW on forest salamanders. Salamander occupancy increased as distance from the ROW edge increased, due to the negative effects of edge. Occupancy overall decreased as ROW age increased, and occupancy at all distances from the ROW edge decreased as ROW age increased. This suggests that edge effects degrade habitat along ROW over time, and that edge effects influence adjacent forest for at least 30m (farthest cover boards from the ROW edge). Snakes were observed on the ROW more than on the edge or in forest, and rodents were observed at most ROW sites. These suggest that snakes are more likely to utilize ROWs and that prey abundance is higher. Pollinators were more likely to be found at sites with higher percentages of flowering forbs. Butterfly species richness, butterfly density, and bee density were all positively related to the percent of flowers on the ROW. Pollinator density of each transect $(10 \mathrm{~m} \times 100 \mathrm{~m})$ was not related to total ROW width, indicating that pollinator density is a function of flower 
abundance rather than an interaction between width and flower abundance. This suggests that pollinator abundance would increase as ROW width increases assuming flower percentage remains constant.

For the species in this study, ROW width negatively impacts forest salamanders but can be beneficial to snakes and pollinators. Differences in seed mix will change available food resources and vegetative structure. The best reclamation plan will vary based upon the circumstances and most imperiled species at each location. Overall, ROWs should be located along existing disturbance in forested areas to limit additional forest fragmentation. Reclamation should include seed mixes that prioritize native plants and maximize flowering throughout the growing season. The temporary workspace of each ROW should be replanted with fruiting trees and shrubs to increase forage for wildlife and soften the forest edge to reduce edge effects on salamanders. A ROW with these characteristics provides a balance between wildlife while providing resources which would otherwise be absent. 


\section{Acknowledgments}

I would like to sincerely thank both of my co-advisers Dr. John W Edwards and Dr. Shawn T Grushecky for their assistance with all aspects of my master's degree, from class choice to research. I am grateful for this opportunity at West Virginia University, and feel that the interdisciplinary background of my co-advisers improved my learning experience. I would also like to thank the third member of my committee, Dr. Sheldon Owen, for his assistance and expertise with the pollinator portion of my research and thesis. This research would not have been possible without the help of the Pennsylvania Game Commission and Department of Conservation and Natural Resources. Dr. Linda Ordiway (formerly of the Ruffed Grouse Society, currently with the WV Department of Natural Resources) was also instrumental in providing assistance to the planning phase of the ruffed grouse portion of this project. Kevin, a fellow graduate student, helped tremendously with forestry measurements of my study sites as well. Finally, I would like to thank my family and loved ones for their support during my time at WVU. 


\section{Table of Contents}

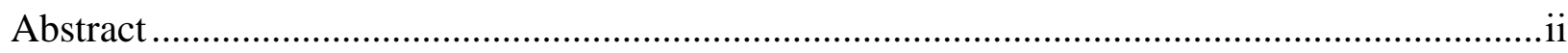

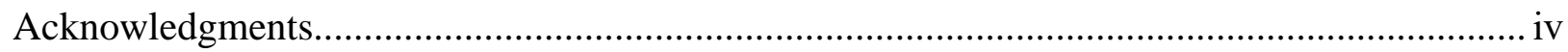

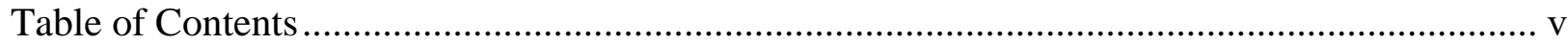

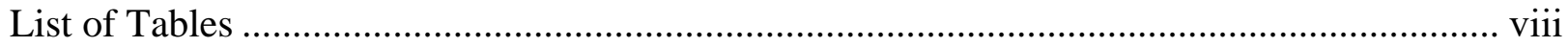

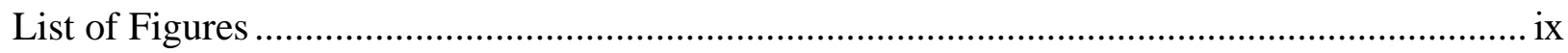

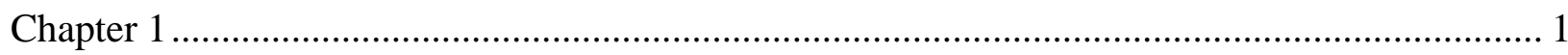

Wildlife and Natural Gas Pipeline Literature Review …….................................................... 1

Unconventional Natural Gas Development..................................................................... 2

Gas Development and Forest Fragmentation ......................................................................... 4

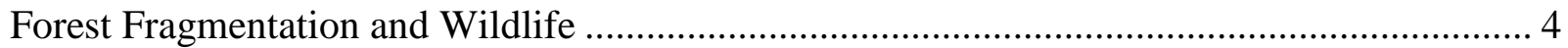

Powerline Rights of Way (A surrogate for Unconventional Natural Gas pipelines) .................. 5

Ruffed Grouse Population Cycle, Survival, and Reproduction ............................................... 7

Ruffed Grouse Habitat ......................................................................................... 10

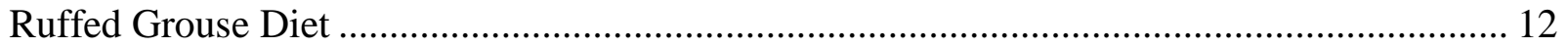

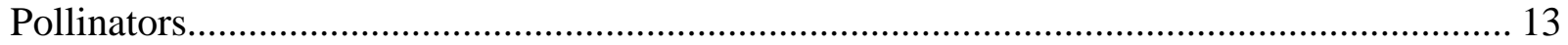

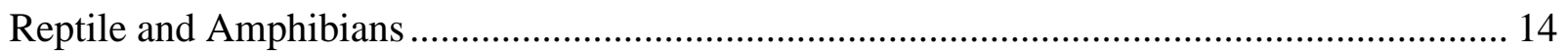

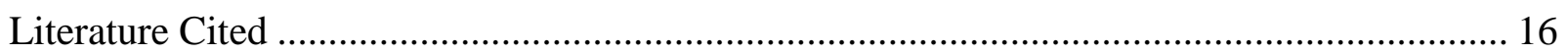

Chapter 2:_Ruffed Grouse Occupancy along Natural Gas Pipeline Right of Ways in Northern Pennsylvania ................................................................................................................... 21

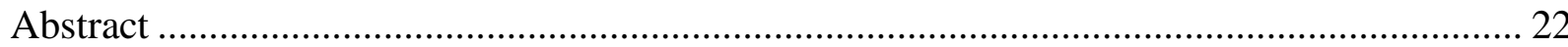

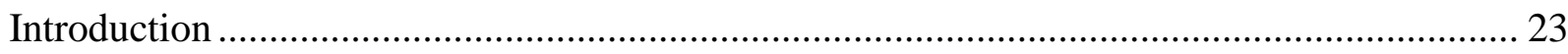

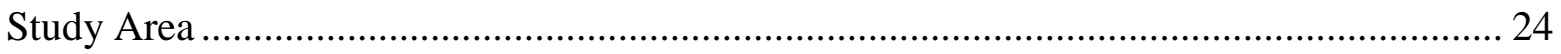

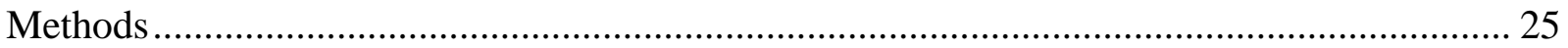

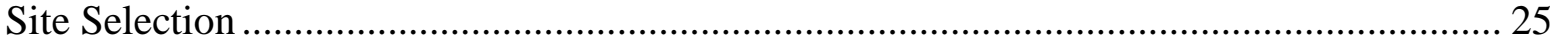

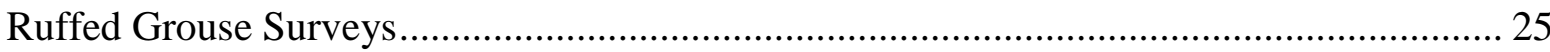

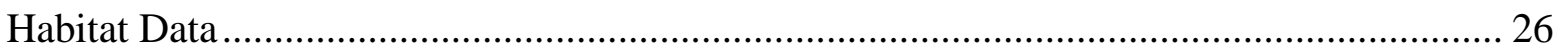

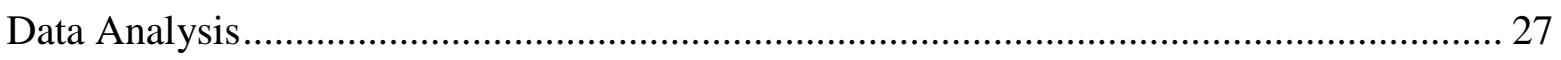

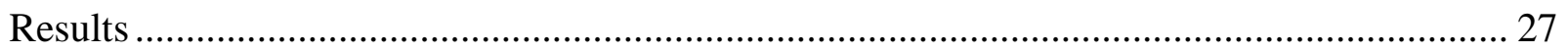

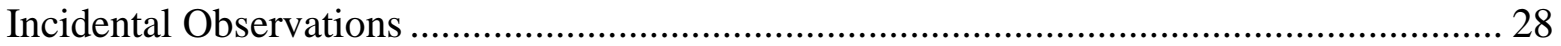

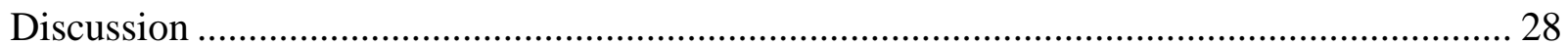

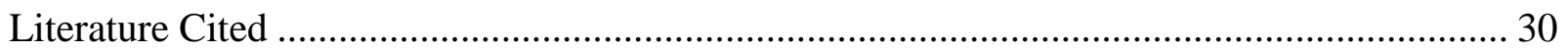




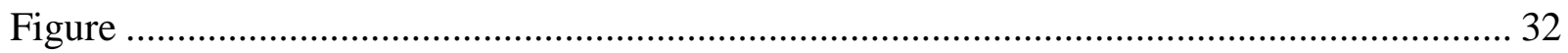

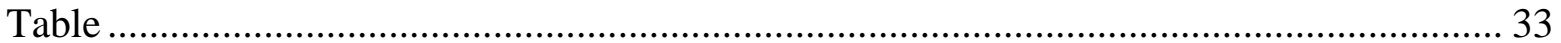

Chapter 3: Influence of natural gas pipeline right of ways on occurrence of amphibians and

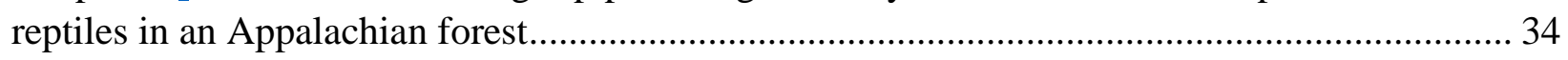

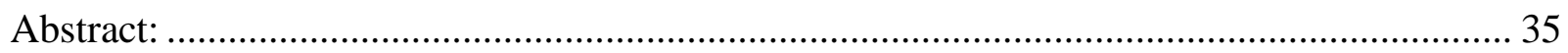

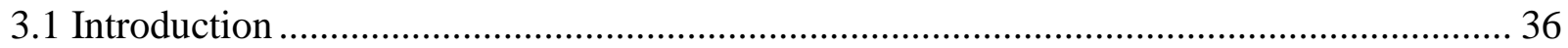

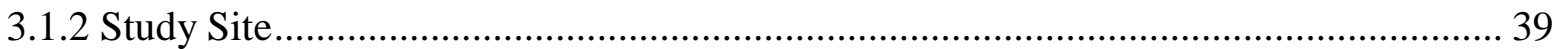

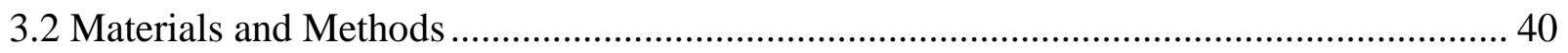

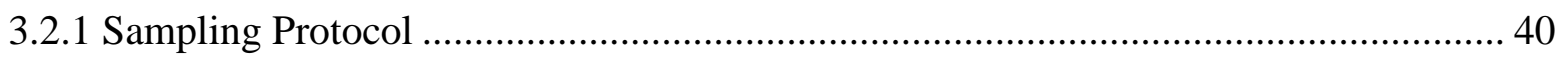

3.2.2 Site and Survey Variables.............................................................................. 42

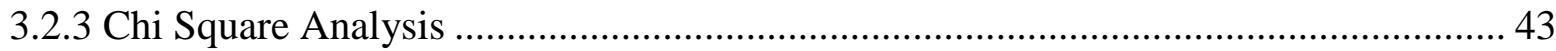

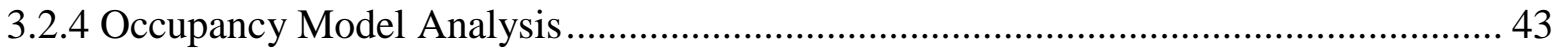

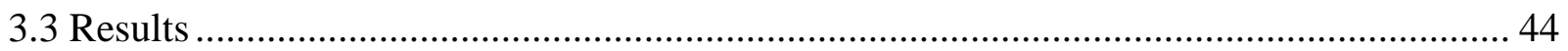

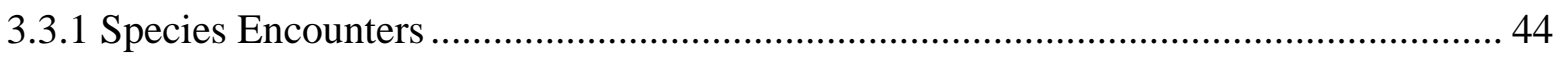

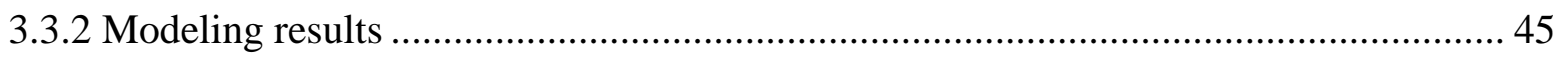

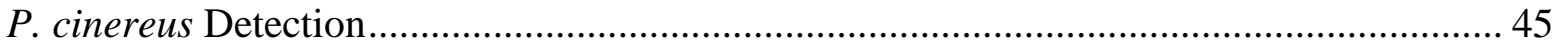

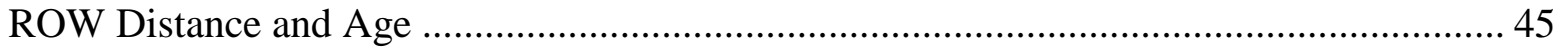

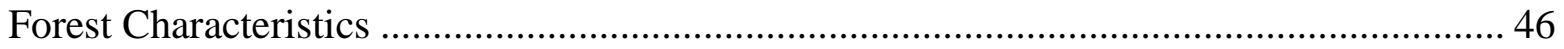

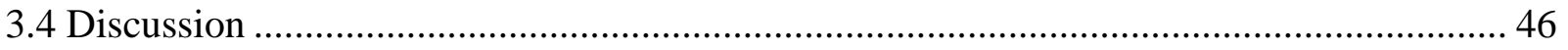

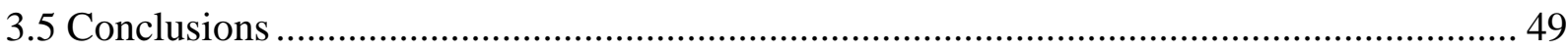

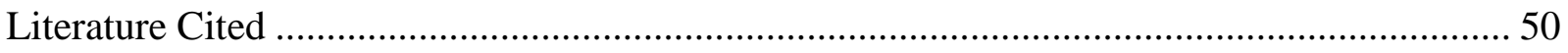

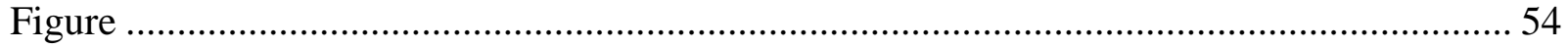

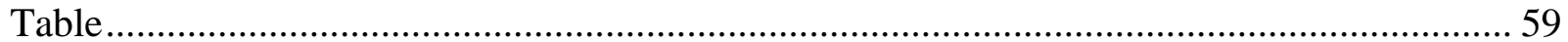

Chapter 4: Variation in Pollinator Presence Along Natural Gas Pipeline Right of Ways in

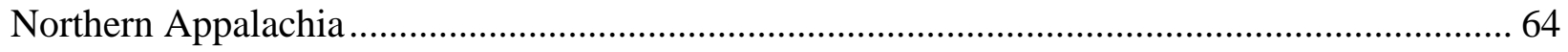

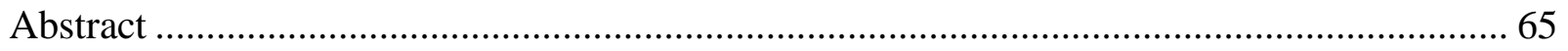

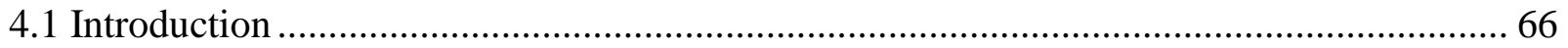

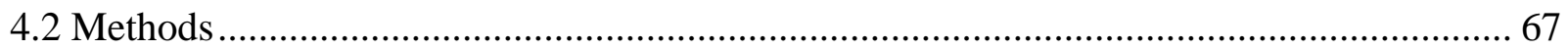

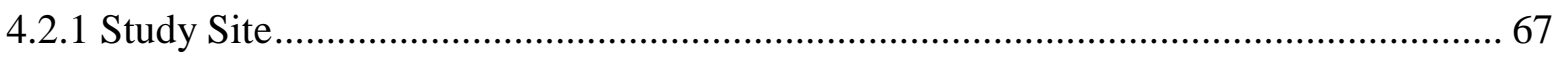

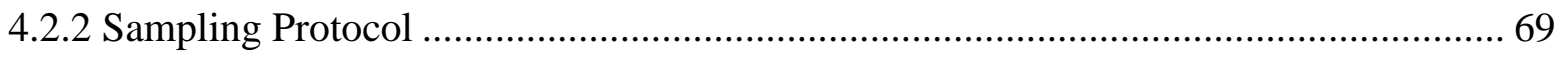

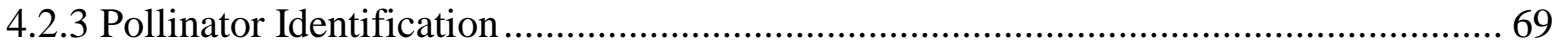

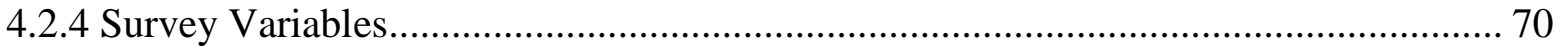

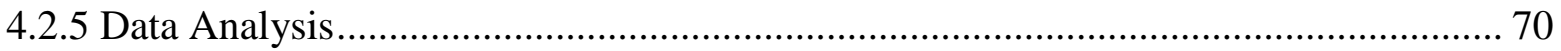




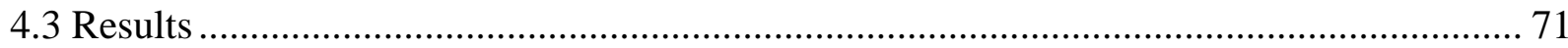

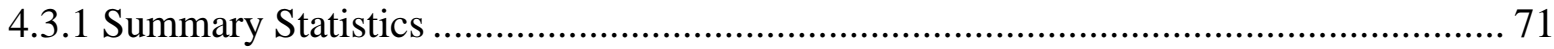

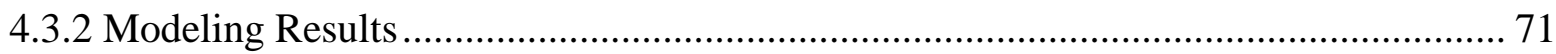

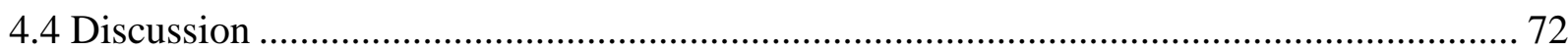

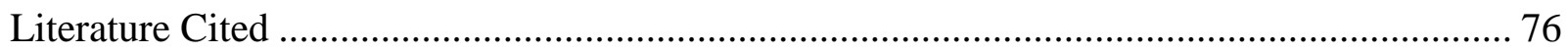

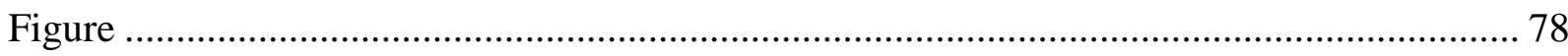

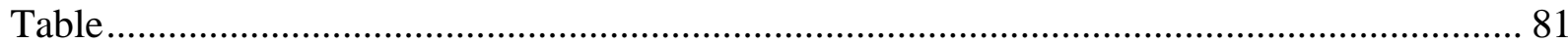

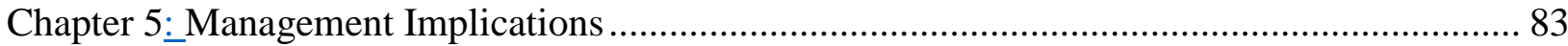

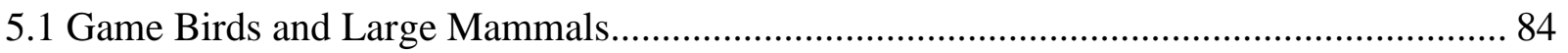

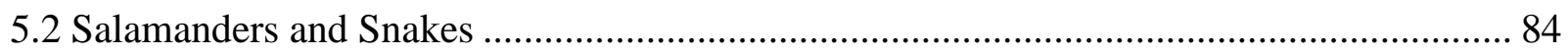

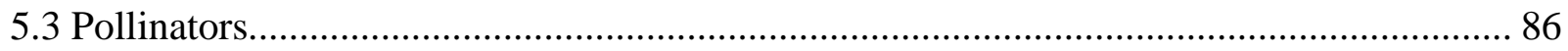

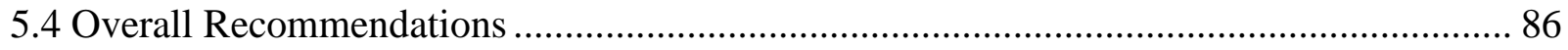

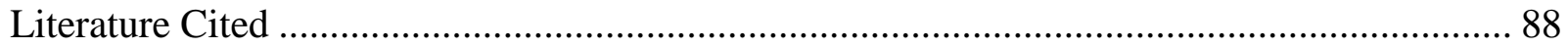

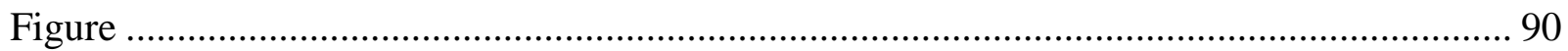

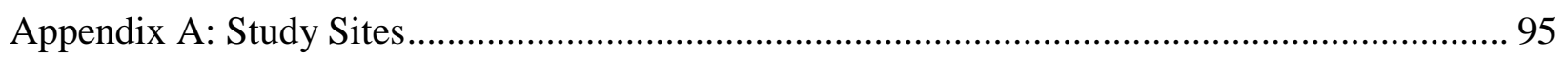

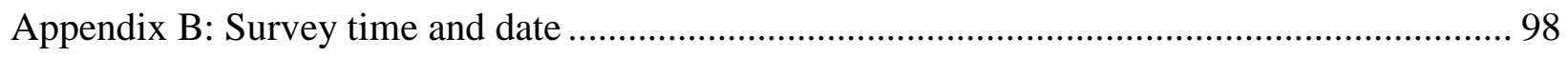

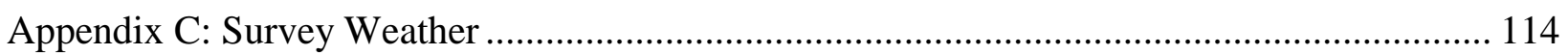

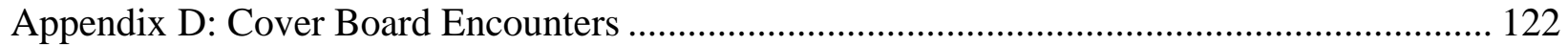

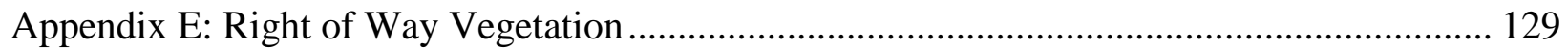

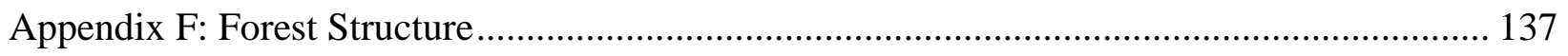

Appendix G: Seed Mix Composition.............................................................................. 145

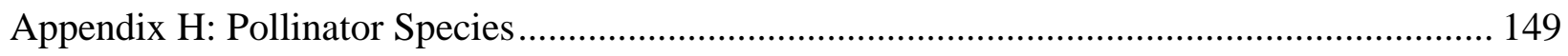

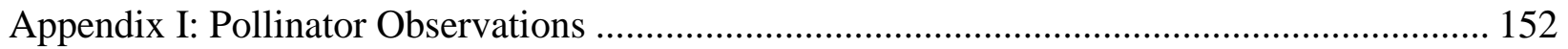




\section{List of Tables}

Table 2.1: Incidental wildlife observations along natural gas pipelines in the Tiadaghton State Forest and Game Lands 12 of Pennsylvania

Table 3.1: Covariates recorded to account for imperfect detection during cover board surveys for salamanders.

Table 3.2: Surrounding forest measurements taken at all cover board sites used for forest structure modeling.

Table 3.3: Catch per coverboard set for all salamander and snake species encountered during coverboard surveys.

Table 3.4: Model results for Phlethodon cinerues occupancy over all cover board sites ranked by AICc. Model sets for detection, ROW age and distance from ROW center, and forest structure were modeled independently.

Table 3.5: Estimated beta coefficients for ROW age and distance from ROW center from $P$. cinereus model selection.

Table 4.1: Covariates included in modeling to predict pollinator richness and density.

Table 4.2: Modeling results for butterfly richness, butterfly density, and bee density along natural gas pipeline ROWs in Pennsylvania. 


\section{List of Figures}

Figure 2.1: Relative location of study sites within the state of Pennsylvania and map representative of Tiadaghton state forest and game lands 12.

Figure 3.1: Relative location of study sites within the state of Pennsylvania and map representative of Tiadaghton state forest and game lands 12.

Figure 3.2: Cover board array placement in relation to the right of way.

Figure 3.3: Predicted $P$. cinereus detection probability related with temperature.

Figure 3.4: Predicted $P$. cinereus occupancy probability related with pipeline right of way (ROW) age and cover board distance from the ROW center.

Figure 3.5: Predicted $P$. cinereus occupancy probability related with top supported forest structure covariates: canopy cover, basal area of trees larger than $15.24 \mathrm{~cm}$ dbh within $10 \mathrm{~m}$, and the count of trees larger than $15.24 \mathrm{~cm}$ dbh within $10 \mathrm{~m}$.

Figure 4.1: Relative location of study sites within the state of Pennsylvania and map representative of Tiadaghton state forest and game lands 12.

Figure 4.2: Predicted butterfly species richness, butterfly density, and bee density based on the percentage of flowers present on a natural gas pipeline ROW.

Figure 4.3: An example of natural gas pipeline right of ways (ROW) with large differences in flower percentage due to seed mix choice during reclamation.

Figure 5.1: Eastern wild turkey (Meleagris gallopavo) hen observed on a pipeline ROW.

Figure 5.2: Pipeline right of way with high pollinator density and high flower percentage.

Figure 5.3: Pipeline right of way with low pollinator density, poor vegetation diversity, and no flower growth.

Figure 5.4: An example of a natural gas pipeline ROW temporary workspace has been replanted with trees and shrubs, and the pipeline routed along an existing road.

Figure 5.5: Example of a rock structure constructed along a natural gas pipeline ROW to provide hibernacula for snakes. 


\section{Chapter 1}

Wildlife and Natural Gas Pipeline Literature Review 


\section{Literature Review}

\section{Unconventional Natural Gas Development}

The recent development of horizontal drilling for natural gas and oil expanded fossil fuel derived resource extraction throughout the United States. This method of drilling has enabled natural gas to be produced much more cost effectively, with more wells located on each well pad and the ability to access more gas deposits per well (Carter et al. 2011). The Marcellus shale in Pennsylvania has seen widespread use of this technology since 2004 (Carter et al. 2011) and has nearly 17,000 permitted unconventional wells as of 2018 (PADEP 2018). Energy development is expanding at the most rapid pace in US history and energy sprawl within the United States is expected to impact an area the size of Texas by 2040 (Trainor et al. 2016).

Conventional wells drilled for oil and natural gas have been present in Pennsylvania for more than 150 years (Carter et al. 2011). Conventional wells are drilled vertically, and generally are not as deep as unconventional wells (Carter et al. 2011). Conventional wells are traditionally located on individual well pads, while unconventional well pads normally have multiple wells located on them (Carter et al. 2011). Unconventional well pads are larger to accommodate the additional wells and required equipment necessary for drilling and fracking (Drohan et al. 2012). Conventional development leads to increased numbers of small well pads, whereas unconventional development tends to limit overall disturbance at the cost of larger well pads.

Research has shown negative impacts or the potential for negative impacts of unconventional natural gas development on ecosystems. In the central United States, unconventional gas development is hypothesized to negatively impact ecosystem services though the reduction of net primary production (removal of vegetation for development), use of water 
for hydraulic fracking, and disruption of wildlife through fragmentation from infrastructure (Allred et al. 2015). Rapid unconventional gas well development has the potential to negatively impact freshwater organisms (brook trout (Salvelinus fontinalis) and mussels), fragmentationsensitive species (interior forest birds, forest orchids), and species with limited range (tonguetied minnow (Exoglossum laurae), Wehrle's salamander (Plethodon wehrlei) (Kiviat 2013). In Alberta, Canada grasslands, natural gas development had negative impacts on nesting success of some grassland songbirds (Sprague's pipit (Anthus spragueii) and Baird's sparrow (Ammodramus bairdii)) (Ludlow et al. 2015). This was attributed to the invasion of crested wheatgrass (Agropyron cristatum) following development and newly created access roads. Crested wheatgrass (a non-native) often becomes established after anthropomorphic disturbance (Ludlow et al. 2015). Gas development appears to have negative impacts on forest-specialist passerines, while promoting synanthropic species that are able to more effectively utilize a fragmented landscape (Fronk 2013, Barton et al. 2016).

The location of new infrastructure is dependent both on existing well pad locations and local land ownership. The location of gathering pipelines is most dependent on land ownership, and to a lesser extent on roads, topography, and land use (Donnelly 2018). There is a strong preference to locate new pipelines near edges of land parcels. More agricultural than forest land is converted for infrastructure (not including pipelines), showing a preference by gas companies. Agricultural land is cheaper to drill on and restore than forestland (Jantz et al. 2014). Conventional vertical wells and unconventional horizontal wells required similar amounts of forest clearing (Hill 2015). Wells that required hydraulic fracturing had larger pads, required more forest clearing, and additional roads (Hill 2015). Conventional oil/gas development has the 
potential to expose aquatic ecosystems to more risk than unconventional development, because of the increase in infrastructure ( Slonecker and Milheim 2015).

\section{Gas Development and Forest Fragmentation}

Shale gas development in the Appalachians (Marcellus shale) and elsewhere is known to cause increased fragmentation of forests through well pad and pipeline construction (Abrahams et al. 2015). Extensive shale gas development in areas with forest cover is causing fragmentation and habitat loss of core forest (Drohan et al. 2012). Fragmentation of core forest habitat and the associated increase in road construction also has the potential to negatively impact headwater streams in an area (Drohan et al. 2012). Based on development of the Fayetteville shale in Arkansas, forest cover decreased as development increased (Moran et al. 2015). This resulted in increased edge effects from roadways, well pads, and pipeline infrastructure. Oil and gas development in Bradford and Washington Counties, Pennsylvania resulted in increases in forest edge and forest fragmentation from 2004 to 2010, mostly attributable to pipelines (Slonecker Et al., 2012); Patch number increased and average patch size decreased due to development (Slonecker et al., 2012). Overall forest also decreased, with more interior than edge forest being lost (Slonecker et al. 2012). There is a tendency for unconventional development to occur in interior forest areas, resulting in increased fragmentation and edge effects (Slonecker and Milheim 2015). The edge effects of a large clearing in the center of a forest patch may be unique in the sense that the edge is isolated within a forest patch (Slonecker and Milheim 2015).

\section{Forest Fragmentation and Wildlife}

Habitat fragmentation often negatively impacts forest specialists and positively impacts generalist species. Fronk (2013) examined the effects of shale gas development on synanthropic (species which benefit from human development, often generalists), early-successional, and 
forest- interior bird species abundance in Pennsylvania. Synanthropic species increased in abundance in relation to development, while forest-interior species showed a decline (Fronk 2013). Early-successional species showed no relationship to development (Fronk 2013). It is expected that trends will increase in intensity as development continues (Fronk 2013). Habitat fragmentation and edge effects appear to be harmful to amphibians by decreasing habitat connectivity (Cushman 2006). Fragmentation is likely to impact amphibians at short- and longterm time scales. There is the potential for a reduction in Plethodontid salamander ranges from Marcellus shale gas development, primarily from loss of forest cover and fragmentation (Brand et al. 2014).

Some species appear to be unaffected by fragmentation, unlike forest birds and amphibians referenced above. In an Australian fragmented landscape, reptile abundance and richness remained constant despite various levels of fragmentation (Schutz and Driscoll 2008). The most common species are able to persist despite the fragmentation and loss of plant diversity, although some species were rarely found outside of a preserved area (Schutz and Driscoll, 2008). This suggests common reptiles are able to persist through landscape fragmentation, at least in Australia.

\section{Powerline Right-of-Ways (A surrogate for Unconventional Natural Gas pipelines)}

Powerline ROWs are a useful analog for pipeline ROW because they have been studied over a longer period of time. Although not identical, pipeline ROWs and powerline ROWs are functionally similar. Both pipeline ROW and powerline ROWs are maintained in an early successional state (Wagner et al. 2014). Pipeline ROWs are expected to have more soil disturbance and more comprehensive vegetation removal than powerline ROW's. Procedures can vary substantially, but generally there are no trees allowed to grow within the ROW to protect 
infrastructure. Right-of-ways in forested areas are managed through mechanical, chemical, or a combination of methods. Recent literature suggests these early-successional ROWs, if managed correctly, can provide habitat for many imperiled species such as Epeoloides pilosula in Connecticut, 2 state endangered plants in Georgia (Sarracenia purpurea, Sarracenia rubra), and 3 state endangered plants in Maryland (Juncus caesariensis, Drosera capillaris, Smilax pseudochina)( Wagner and Ascher 2008, Sheridan et al. 1999) .

Compared to adjacent woodland areas, powerline ROWs in New England had higher species richness and diversity of plant communities (Wagner et al. 2014, Eldegard et al. 2017a). This is most likely because the ROWs receive an intermediate amount of disturbance, much more than adjacent forest. Intermediate disturbance results in the highest diversity in the herbaceous layer of vegetation (Roberts and Gilliam 2014). Utility ROWs are often managed at a level of intermediate disturbance (Roberts and Gilliam 2014). Invasive species were more prevalent in ROWs, but total area covered by invasive species was low in both areas (Wagner et al. 2014). Richness was highest in areas with access roads along the ROW (Wagner et al. 2014). It is hypothesized that increased richness in ROWs is a result of increased light, heterogeneity of structure, and variation in soil microclimate (Wagner et al. 2014). Several plant species that are important food sources for pollinators are often found in these ROWs. Goldenrod (Solidago Sp.), a plant that provides a majority of late season pollen to a variety of insects, was significantly more abundant in ROWs than in adjacent woodlands (Wagner et al. 2014).

Right of ways managed at an intermediate level of disturbance to discourage tree growth provide habitat for pollinator species. Powerline ROWs provide bumblebee habitat similar to a semi-natural grassland (Hill and Bartomeus 2016). Powerline ROWs are also an important source of butterfly habitat and increase diversity and abundance in adjacent areas (Berg et al. 
2016). A rare species of bee (Epeoloides pilosula) thought to be extinct was discovered along a powerline ROW in southeastern Connecticut (Wagner and Ascher 2008). This is the only known colony of the species, and its persistence in a primarily binary landscape (forested or developed) can be attributed to early successional habitat provided by powerline ROWs. The management of powerline ROW vegetation has the potential to positively benefit bumblebee conservation and the associated ecosystem services of pollination.

Vegetation along powerline ROW can be managed to conserve a number of ecosystem services including carbon sequestration and nesting habitat for wildlife (Dupras et al. 2016). With regular clearing, Eldegard et al. (2017) suggest these areas can improve richness of insectpollinated plants and offset the loss of species associated with semi-natural grasslands. In Massachusetts, shrub-scrub birds (passerines) were found to occupy powerline ROWs (King et al. 2009). Nest success was higher in wider ROWs $(49 \mathrm{~m}+)$, and some species were only found in intermediate or larger ROWs (King et al. 2009). When managed "correctly" (to allow some growth of shrubs) there is potential for powerline ROWs to offer habitat to shrub birds that are in decline (King et al. 2009). Powerline ROWs can also offer refugia for rare disturbance-adapted plants that may be otherwise extirpated from a fire suppressed or predominately woodland environment (Sheridan et al. 1997).

\section{Ruffed Grouse Population Cycle, Survival, and Reproduction}

Ruffed grouse populations in the Appalachian region face challenges unique to that locale. Aspen (Populus tremuloides) is an abundant and high-quality winter food resource that is available to populations at northern latitudes (Tirpak et al. 2006, Devers et al. 2007). This resource is present in northern Pennsylvania but largely absent from the remainder of the Appalachian region. Lower quality food resources in the Appalachian region are thought to 
contribute to low observed reproductive rates in ruffed grouse (Devers et al. 2007). Grouse in northern latitudes rely heavily on aspen buds for winter food resources, while Appalachian grouse must rely on mountain laurel (Kalmia latifolia) and Christmas fern (Polystichum acrostichoides) (Tirpak et al. 2006). For an equal energy intake, more time must be spent foraging for these low- quality food resources compared to high- quality aspen and increased foraging time is directly related to increased predation risk (Tirpak et al. 2006). The reproductive "boom" during mast years is thought to offset the declining population in other years, thus maintaining population size (Tirpak et al. 2006). Juvenile survival is low each year, meaning female adult survival influences population size in this region (Tirpak et al. 2006). Blomberg et al. (2012) conducted population modeling on eastern ruffed grouse, which showed that survival and recruitment had the highest influence on population size.

Within the Appalachian region, there are two main forest types used by grouse, oakhickory and mixed- mesophytic (Devers et al. 2007). The reproductive rates of grouse differed between forest type; oak-hickory populations had lower reproductive rates but higher survival compared to mixed- mesophytic forest (Devers et al. 2007). Overall chick survival was lower than other regions, and this metric had the highest impact on population growth in the region (Devers et al. 2007). The survival rate of adults and juveniles differed, as did the rate between breeding and non-breeding seasons (Tirpak et al. 2006). Juvenile and breeding adult mortality is likely due to higher exposure to predators while foraging or from dispersal (Tirpak et al. 2006). No evidence of differential fertility in age classes was found (Tirpak et al. 2006). Reproduction and survival rates are low in most years, and the population is expected to slightly decline in most years before being replenished during mast "boom” years (Tirpak et al. 2006). Onehundred percent of females are thought to attempt nesting each year, and produce an average of 
10 eggs per nest (Devers et al. 2007). Hatch rate is high at $80-90 \%$ after an incubation period of 24 days, and failed eggs are not thought to influence population dynamics (Bump et al. 1947, Devers et al. 2007). Grouse have been up to 9 years old when harvested (Decker Major et al. 1981).

Food resources in the Appalachian region appear to strongly influence reproductive success (Tirpak et al. 2006, Devers et al. 2007). Observed differences in reproductive rates between oak-hickory and mixed-mesophytic sites are correlated with food production, with mixed-mesophytic forests producing more food and showing higher reproductive rates (Devers et al. 2007). Mixed-mesophytic forests produce more hard mast, generally, than oak-hickory forests (Devers et al. 2007).

Outside of chick survival, the primary factor of mortality in grouse populations is predation (Devers et al. 2007). In the Appalachian region, predation accounted for $84 \%$ of observed mortality of adults (Devers et al. 2007). The main predators of grouse are avian, which are primarily Cooper's hawks (Accipiter cooperii) and owls in the Appalachians (Northern Goshawks (Accipiter gentilis) in northern latitudes) (Bumann 2002). There is no strong evidence that spring grouse counts (based on drumming) are correlated with (gos)hawk abundance in northern latitudes (Zimmerman et al. 2013). The best support (albeit low, best model only explained $17 \%$ of the observed data) model for predicting spring grouse counts was for winter weather (Zimmerman et al. 2013). Cold and wet winters were most favorable to survival compared to warm and wet winters because soft snow is hypothesized to provide thermal insulation (i.e., snow roosting) and more cover from predators than a hard crust (Zimmerman et al. 2013). 
During spring, male ruffed grouse produce non-vocal sounds from the center of their territory (often from a "drumming log") to attract females to mate (Bump et al. 1947). They wing-beat rapidly to produce a low pitched "drumming" that can be heard from nearly $400 \mathrm{~m}$ away in woodlands (Bump et al. 1947). Drumming counts during spring have been used to estimate grouse population numbers (Zimmerman and Gutiérrez 2007). Sex ratio is usually close to 1:1 at the time of drumming, although not all males drum each year (Gullion 1981, Zimmerman and Gutiérrez 2007). There is a portion of the male population that does not partake in drumming each year, effectively a non-reproductive male (Gullion 1981). This proportion is correlated with the relative population size, based on availability of high-quality drumming sites (Gullion 1981). In years of high population, a larger proportion of non-drumming males is expected to occur, and vice versa. Survival of non-drumming males was the same or better than that of drumming males, likely a result of a lower predation risk (Gullion 1981). Drumming logs of males approximate the center of their territories and the surrounding areas are utilized throughout the year (Zimmerman and Gutiérrez 2007). Detection probability was low during surveys by Zimmerman and Gutiérrez (2007) at approximately 0.33 per day. It was found that temperature change during a survey was most correlated with detection probability (Zimmerman and Gutiérrez 2007). In this case rapid warming produced higher detection.

\section{Ruffed Grouse Habitat}

The two types of forest used by grouse in the Appalachian region are predominately oakhickory and mixed-mesophytic vegetation types (Devers et al. 2007). These two vegetation types produce different reproductive and survival rates among grouse. Grouse also utilize young forest habitat, roughly classified as $0-20$ years old (Tirpak et al. 2010). Grouse density was correlated with hardwood regeneration areas between 7 and 15 years old (Wiggers et al. 1992). Ruffed 
grouse in Connecticut were found to be more abundant in young forest stands (15-22 years old) than other forest habitats (Duguid et al. 2016). Young forest cover and roads have been documented to be important for grouse, regardless of sex or age (Tirpak et al. 2010). Forestland should be managed for approximately $3-4 \%$ young habitat to benefit grouse (Tirpak et al. 2010). Population persistence was modeled using vital rates and measures of habitat quality by Blomberg et al. (2012); persistence was highest when an equal area of high-quality habitat was located in few large patches rather than many small patches.

Maturing forest habitat in the Appalachian region has negatively impacted ruffed grouse because of a reduction in young forest habitat (Tirpak et al. 2010). High stem density young forest is used during winter and spring as predation cover due to the protection it provides compared to older woodlands (Tirpak et al. 2010). Predation risk is higher during the winter when leaves are absent and for drumming males in spring than other times of the year. The availability of denser cover that young forests provide reduces this predation risk. Males seem to occupy 1-10-year-old growth with high stem density while drumming, and breeding females occupy areas that exhibit characteristics of $10-20$-year-old growth (Tirpak et al. 2010). Young forest also provides more food resources for grouse, including soft mast, twigs, and buds (Tirpak et al. 2010). Grouse avoid agricultural areas due to the lack of cover they provide (Tirpak et al. 2010). Adults also seem to occupy higher quality habitat than juveniles (Tirpak et al. 2010).

Road edges may provide early successional habitat and also serve as travel corridors between areas of habitat (Tirpak et al. 2010). Road edges are also used for feeding, chick rearing, displaying, and dusting (Tirpak et al. 2010). Roads and forest edge were positively related to grouse numbers in a study conducted by Tirpak et al. (2010). 
Access to early successional habitat is important for chick survival, which is lower in the Appalachian region than other parts of the ruffed grouse's range. Successful broods selected

young forest habitat $<20$ years old, maintained forest openings, and the edge of roadways (Jones et al. 2008). Female ruffed grouse with broods utilized forest cover that had a highly developed canopy (over $70 \%$ cover) (Haulton et al. 2003). These areas had a higher percentage of ground cover, taller ground cover, and more arthropods than random sites (Haulton et al. 2003). In contrast with previous studies, total stem density was similar between control and experimental sites (Haulton et al. 2003). This suggests quality of ground cover is more important than stem density, or that stem density itself is a poor indicator of quality habitat for brooding females.

\section{Ruffed Grouse Diet}

In northern latitudes, aspen buds are a very important winter food resource that are absent in lower elevations in the Appalachians (Svoboda and Gullion 1974). Due to the lower quality and quantity of food resources in the southern Appalachians compared to northern latitudes, ruffed grouse have been observed to forage much longer on average during winter (Hewitt et al. 1997). It is suggested this may contribute to increased predation during that season. A diet and fat analysis on southern Appalachian (SW Virginia) ruffed grouse indicated changes in diet throughout the year (Norman and Kirkpatrick 1984). Primary diet shifted from herbaceous plant leaves in spring and summer to hard and soft fruits in autumn to soft fruits in winter (Norman and Kirkpatrick 1984). Herbaceous plants used as food resources included Christmas fern, dwarf cinquefoil (Potentilla canadensis), wintergreen (Gaultheria procumbens), and mayflower (Epigaea repens) (Norman and Kirkpatrick 1984). Greenbrier (Smilax spp.), wild grapes (Vitis spp.), viburnum (Viburnum spp.), dogwood (Cornus spp.) and wild rose (Rosa spp.) comprise soft-fruiting plants in ruffed grouse diet (Norman and Kirkpatrick 1984). Grouse diet of hard 
fruits includes acorns from white oak (Quercus alba), scrub oak (Q. ilicifolia), and red oak (Q. rubra) along with various sumac species (Rhus spp.) (Norman and Kirkpatrick 1984). White oak acorns are more nutritious and palatable to ruffed grouse than red and black oak acorns (Servello and Kirkpatrick 1989). Grouse have also been observed eating both amphibians (American toad (Anaxyrus americanus) and reptiles (garter snakes) indicating they are likely part of the diet, at least in fall (Hale and Wendt 1951). Stafford and Dimmick ( 1979) found that primary autumn and winter foods of grouse in Tennessee were greenbrier (Smilax spp.), mountain laurel, and Christmas fern.

\section{Pollinators}

There are many species of pollinating insects present in Pennsylvania, including butterflies, moths, bees, flies, and wasps, among others. There are thought to be $400+$ species of pollinating bees present in Pennsylvania alone, which include bumblebees (Bombus spp.), sweat bees (Halictus spp.), leafcutter bees (Megachile spp.), squash bees (Peponapis pruinosa), honey bees (non-native, Apis mellifera), mason bees (Osmia spp.), mining bees (Andrena spp.), and carpenter bees (Xylocopa spp.) (The Pennsylvania Pollinator Protection Plan 2019).

Pennsylvania is also home to 156 species of pollinating butterflies (The Pennsylvania Pollinator Protection Plan 2019). These range from the common cabbage white (Pieris rapae) to the federal listed karner blue (Lycaeides Melissa samuelis). Other insect pollinators that will not be a focus of this study include moths, flies, and wasps due to difficulty of identification.

Pollinators are undergoing declines nationwide due to habitat loss and degradation, forest succession, and widespread pesticide applications (The Pennsylvania Pollinator Protection Plan 2019). Less natural disturbance is occurring now in forest areas of Pennsylvania than did previously, resulting in fewer areas of young forest and the flowering plants that grow in them 
(Winfree et al. 2008). Young forest provides nesting habitat and food resources (plant nectar) for pollinators. There is also a general trend in Pennsylvania of forest maturation, reducing the amount of young forest and field ecotypes (The Pennsylvania Pollinator Protection Plan 2019). This trend does not have a positive impact on pollinator populations.

Pollinator species can benefit from unconventional natural gas development (Russell et al. 2018). ROWs are managed for grasses, forbs and shrubs to discourage tree growth near the pipeline until the infrastructure is removed. Plantings of native annuals and perennials are expected to increase pollinator habitat in areas that were previously contiguous forest (Hill and Bartomeus 2016, Russell et al. 2018). Powerline ROWs are valuable refugia for declining pollinator species (Sheridan et al. 1997, Russell et al. 2018).

\section{Reptile and Amphibians}

Pennsylvania is home to a multitude of reptiles and amphibians, of which snakes, lizards, and salamanders will be a focus of this study. The potential study species present in the northcentral Pennsylvania study area include 3 lizards and skinks, 15 snakes, and 14 salamanders (see Appendix A for full list)(Pennsylvania Native Reptile and Amphibian Species 2019). Some species, such as the eastern garter snake (Thamnophis sirtalis) and redback salamander (Phlethodon cinereus), are abundant throughout their range. Other species, such as Wehrle's salamander (Plethodon wehrlei) and the timber rattlesnake (Crotalus horridus) are declining (Pennsylvania Native Reptile and Amphibian Species 2019).

Habitat requirements are similar among Pennsylvania's woodland salamanders and lizards. These species' habitat is primarily restricted by temperature and moisture (Cushman 2006, Andrews et al. 2008). Without adequate cover, high temperatures and low moisture will 
quickly kill amphibians and reptiles. In the hardwood forests of Pennsylvania, heat and moisture protection is provided by coarse woody debris, leaf litter, mature trees, and rocks (Moseley et al. 2010). Woodland salamanders are able to remain underground when surface conditions are unsuitable. Snakes require more diverse habitat than salamanders, to include denning sites in winter and basking sites in spring and fall (Andrews et al. 2008).

Snakes, lizards, and salamanders are most likely to be impacted by unconventional gas development in a forested ecosystem. Forest salamanders are negatively affected by edge effects and road construction (Andrews et al. 2008, Moseley et al. 2010, Brand et al. 2014). Populations of redback salamanders decreased with increasing forest fragmentation due to additional sunlight and drying wind (Brand et al. 2014). Snakes and lizards are more resilient than salamanders to environmental conditions, and show similar species diversity pre/post disturbance (Schutz and Driscoll 2008). Schutz and Driscoll (2008) hypothesized that ROW disturbance may locally increase prey populations (e.g., mice, voles, etc.) for snakes. Increased road building and traffic associated with resource extraction limits connectivity and leads to increased mortality from road traffic (Andrews et al. 2008). Cleared areas may also provide basking habitat that is otherwise scarce for reptiles. The Pennsylvania Game Commission and Department of Conservation and Natural Resources have incorporated denning/ basking rock structures into pipeline ROW reclamation plans to improve timber rattlesnake habitat quality (Stauffer 2016). 


\section{Literature Cited}

Abrahams, L. S., W. M. Griffin, and H. S. Matthews. 2015. Assessment of policies to reduce core forest fragmentation from Marcellus shale development in Pennsylvania. Ecological Indicators 52:153-160. Elsevier Ltd. <http://dx.doi.org/10.1016/j.ecolind.2014.11.031>.

Allred, B. W., W. K. Smith, D. J. Twidwell, J. H. Haggerty, S. W. Running, D. E. Naugle, and S. D. Fuhlendorf. 2015. Ecosystem services lost to oil and gas in North America. Net primary production reduced in crop and rangelands. Science 348:401-402. <http://www.sciencemag.org/content/348/6233/401.full.pdf>.

Andrews, K., W. Gibbons, and D. Jochimsen. 2008. Ecological effects of roads on amphibians and reptiles: a literature review. Herpetological Conservation. Volume 3. <http://transwildalliance.org/resources/2009101416234.pdf〉.

Barton, E. P., S. E. Pabian, and M. C. Brittingham. 2016. Bird community response to Marcellus shale gas development. Journal of Wildlife Management 80:1301-1313.

Berg, Å., K. O. Bergman, J. Wissman, M. Żmihorski, and E. Öckinger. 2016. Power-line corridors as source habitat for butterflies in forest landscapes. Biological Conservation 201:320-326.

Blomberg, E. J., B. C. Tefft, J. M. Reed, and S. R. McWilliams. 2012. Evaluating spatially explicit viability of a declining ruffed grouse population. Journal of Wildlife Management 76:503-513.

Brand, A. B., A. N. M. Wiewel, and E. H. C. Grant. 2014. Potential reduction in terrestrial salamander ranges associated with Marcellus shale development. Biological Conservation 180:233-240. Elsevier Ltd. 〈http://dx.doi.org/10.1016/j.biocon.2014.10.008>.

Bumann, G. B. 2002. Factors influencing predation on ruffed grouse in the appalachians.

Bump, G., R. W. Darrow, F. C. Edminster, and W. F. Crissey. 1947. The ruffed grouse: life history, propogation, and management. Telegraph Press, Harrisburg, Pennsylvania.

Carter, K. M., J. A. Harper, K. W. Schmid, and J. Kostelnik. 2011. Unconventional natural gas resources in Pennsylvania: The backstory of the modern Marcellus Shale play. Environmental Geosciences 18:217-257.

Cushman, S. A. 2006. Effects of habitat loss and fragmentation on amphibians: A review and prospectus. Biological Conservation 128:231-240.

Decker Major, P., M. C. Reeves, and C. H. Eisfelder. 1981. A New Longevity Record for the Ruffed Grouse. Journal of Field Ornithology 52:341.

Devers, P. K., D. F. Stauffer, G. W. Norman, D. E. Steffen, D. M. Whitacker, J. D. Sole, T. J. Allen, S. L. Bittner, D. A. Buehler, J. W. Edwards, D. E. Figert, S. T. Friedhoff, W. W. Giuliano, C. A. Harper, W. K. Igo, R. L. Kirkpatrick, M. H. Seamster, H. A. Spiker, D. A. Swanson, and B. C. Tefft. 2007. Ruffed Grouse Population Ecology in the Appalachian Region. Wildlife Monographs 168:1-36. 〈http://doi.wiley.com/10.2193/0084-0173.168>.

Donnelly, S. 2018. Factors Influencing the Location of Gathering Pipelines in Utica and 
Marcellus Shale Gas Development. Journal of Geography and Earth Sciences 6:1-10. <http://jgesnet.com/vol-6-no-1-june-2018-abstract-1-jges>.

Drohan, P. J., M. Brittingham, J. Bishop, and K. Yoder. 2012. Early trends in landcover change and forest fragmentation due to shale-gas development in Pennsylvania: A potential outcome for the northcentral appalachians. Environmental Management 49:1061-1075.

Duguid, M. C., E. H. Morrell, E. Goodale, and M. S. Ashton. 2016. Changes in breeding bird abundance and species composition over a 20 year chronosequence following shelterwood harvests in oak-hardwood forests. Forest Ecology and Management 376:221-230. Elsevier B.V. <http://dx.doi.org/10.1016/j.foreco.2016.06.010>.

Dupras, J., C. Patry, R. Tittler, A. Gonzalez, M. Alam, and C. Messier. 2016. Management of vegetation under electric distribution lines will affect the supply of multiple ecosystem services. Land Use Policy 51:66-75. Elsevier Ltd.

Eldegard, K., D. L. Eyitayo, M. H. Lie, and S. R. Moe. 2017. Can powerline clearings be managed to promote insect-pollinated plants and species associated with semi-natural grasslands? Landscape and Urban Planning 167:419-428. Elsevier. <http://dx.doi.org/10.1016/j.landurbplan.2017.07.017>.

Fronk, N. R. 2013. Initial Response of Birds to Shale Gas Development in a Forested Landscape. Pennsylvania State University.

Gullion, G. W. 1981. Non-Drumming Males in a Ruffed Grouse Population. The Wilson Bulletin 93:372-382.

Hale, J. B., and R. F. Wendt. 1951. Amphibians and Snakes as Ruffed Grouse Food. The Wilson Bulletin 63:200-201.

Haulton, G. S., F. Stauffer, R. L. Kirkpatrick, and G. W. Norman. 2003. Ruffed Grouse ( Bonasa umbellus ) Brood Microhabitat Selection in the Southern Appalachians. The American Midland Naturalist 150:95-103.

Hewitt, D. G., R. L. Kirkpatrick, and D. G. Hewitt1. 1997. Daily Activity Times of Ruffed Grouse in Southwestern Virginia. Journal of Field Ornithology 68:413-420. <http://www.jstor.org/stable/4514244\%0Ahttp://about.jstor.org/terms>.

Hill, B., and I. Bartomeus. 2016. The potential of electricity transmission corridors in forested areas as bumble bee habitat. bioRxiv 027078. <https://www.biorxiv.org/content/early/2016/10/04/027078>.

Hill, D. T. 2015. Land Use Effects of Natural Gas Wells : a Comparison of Conventional Wells in New York To Unconventional Wells in Pennsylvania. Middle States Geographer 48:1-9.

Jantz, C. A., H. K. Kubach, J. R. Ward, S. Wiley, and D. Heston. 2014. Assessing Land Use Changes Due to Natural Gas Drilling Operations in the Marcellus Shale in Bradford County, PA. The Geographical Bulletin 55:18-35.

Jones, B. C., J. L. Kleitch, C. A. Harper, and D. A. Buehler. 2008. Ruffed grouse brood habitat use in a mixed hardwood forest: Implications for forest management in the Appalachians. Forest Ecology and Management 255:3580-3588. 
King, D. I., R. B. Chandler, J. M. Collins, W. R. Petersen, and T. E. Lautzenheiser. 2009. Effects of width, edge and habitat on the abundance and nesting success of scrub-shrub birds in powerline corridors. Biological Conservation 142:2672-2680.

Kiviat, E. 2013. Risks to biodiversity from hydraulic fracturing for natural gas in the Marcellus and Utica shales. Annals of the New York Academy of Sciences 1286:1-14.

Ludlow, S. M., R. M. Brigham, and S. K. Davis. 2015. Oil and natural gas development has mixed effects on the density and reproductive success of grassland songbirds. The Condor 117:64-75. <http://www.bioone.org/doi/10.1650/CONDOR-14-79.1>.

Moran, M. D., A. B. Cox, R. L. Wells, C. C. Benichou, and M. R. McClung. 2015. Habitat Loss and Modification Due to Gas Development in the Fayetteville Shale. Environmental Management 55:1276-1284. Springer US. <http://dx.doi.org/10.1007/s00267-014-0440-6>.

Moseley, K. R., W. M. Ford, J. W. Edwards, and M. B. Adams. 2010. Reptile, amphibian, and small mammal species associated with natural gas development in the Monongahela National Forest, West Virginia. U S Forest Service Research Paper NRS 10:1-14.

Norman, G. W., and R. L. Kirkpatrick. 1984. Foods , Nutrition , and Condition of Ruffed Grouse in Southwestern Virginia. The Journal of Wildlife Management 48:183-187.

PADEP. 2018. Issued Gas Well Permits. Pennsylvania Department of Environmental Protection. <http://www.depreportingservices.state.pa.us/ReportServer/Pages/ReportViewer.aspx?/Oil_ Gas/Permits_Issued_Detail>.

Pennsylvania Native Reptile and Amphibian Species. 2019. Pennsylvania Fish \& Boat Commission. <https://pfbc.pa.gov/nativeAmpRep.htm〉. Accessed 9 Jun 2019.

Roberts, M. R., and F. S. Gilliam. 2014. Response of the Herbaceous Layer to Disturbance in Eastern Forests. The Herbaceous Layer in Forests of Eastern North America 1283:12731283.

Russell, K. N., G. J. Russell, K. L. Kaplan, S. Mian, and S. Kornbluth. 2018. Increasing the conservation value of powerline corridors for wild bees through vegetation management: an experimental approach. Biodiversity and Conservation 27:2541-2565. Springer Netherlands. <https://doi.org/10.1007/s10531-018-1552-8>.

Schutz, A. J., and D. A. Driscoll. 2008. Common reptiles unaffected by connectivity or condition in a fragmented farming landscape. Austral Ecology 33:641-652.

Servello, F. A., and R. L. Kirkpatrick. 1989. Nutritional Value of Acorns for Ruffed Grouse. The Journal of Wildlife Management 53:26-29.

Sheridan, P. M., S. L. Orzell, and E. L. Bridges. 1997. Powerline easements as refugia for state rare seepage and pineland plant taxa. Sixth International Symposium on Environmental Concerns in Rights-of-Way Management. JR Williams, JW Goodrich-Mahoney, JR Wisniewski, and J. Wisniewski, editors. Elsevier Science, Oxford, England 451-460. <http://www.pitcherplant.org/Papers/powerlineeasements.htm>.

Slonecker, E., and L. Milheim. 2015. Landscape Disturbance from Unconventional and Conventional Oil and Gas Development in the Marcellus Shale Region of Pennsylvania, 
USA. Environments 2:200-220. <http://www.mdpi.com/2076-3298/2/2/200/>.

Slonecker, E., L. Milheim, and C. Roig-Silva. 2012. Landscape Consequences of Natural Gas Extraction in Bradford and Washington Counties, Pennsylvania, 2004-2010. US Geological Survey Open ... 2004-2010.

<http://scholar.google.com/scholar?hl=en\&btnG=Search\&q=intitle:Landscape+Consequenc es+of+Natural+Gas+Extraction+in+Bradford+and+Washington+Counties+,+Pennsylvania+ ,$+2004+?+2010 \# 0>$.

Stafford, S. K., and R. W. Dimmick. 1979. Autumn and Winter Foods of Ruffed Grouse in the Southern Appalachians. The Journal of Wildlife Management 43:121-127.

Stauffer, A. 2016. Timber Rattlesnake Conservation Strategy for Pennsylvania State Forest Lands.

Svoboda, F. J., and G. W. Gullion. 1974. Techniques for Monitoring Ruffed Grouse Food Resources. 2:195-197.

The Pennsylvania Pollinator Protection Plan. 2019. <https://ento.psu.edu/pollinators/publications/p4-introduction>.

Tirpak, J. M., W. M. Giuliano, T. J. Allen, S. Bittner, J. W. Edwards, S. Friedhof, C. A. Harper, W. K. Igo, D. F. Stauffer, and G. W. Norman. 2010. Ruffed grouse-habitat preference in the central and southern Appalachians. Forest Ecology and Management 260:1525-1538. Elsevier B.V. 〈http://dx.doi.org/10.1016/j.foreco.2010.07.051〉.

Tirpak, J. M., W. M. Giuliano, C. A. Miller, T. H. Allen, S. Bittner, D. A. Buehler, J. W. Edwards, C. A. Harper, W. K. Igo, G. W. Norman, M. Seamster, and D. F. Stauffer. 2006. Ruffed grouse population dynamics in the central and southern Appalachians. Biological Conservation 133:364-378.

Trainor, A. M., R. I. McDonald, and J. Fargione. 2016. Energy sprawl is the largest driver of land use change in United States. PLoS ONE 11:1-16.

Wagner, D. L., and J. S. Ascher. 2008. Rediscovery of Epeoloides pilosula (Cresson) (Hymenoptera: Apidae) in New England. Journal of the Kansas Entomological Society 81:81-83. <http://www.bioone.org/doi/full/10.2317/JKES703.19.1\%5Cnhttp://www.bioone.org/doi/pdf/10.2317/JKES-703.19.1>.

Wagner, D. L., K. J. Metzler, S. A. Leicht-Young, and G. Motzkin. 2014. Vegetation composition along a New England transmission line corridor and its implications for other trophic levels. Forest Ecology and Management 327:231-239. Elsevier B.V. <http://dx.doi.org/10.1016/j.foreco.2014.04.026>.

Wiggers, E. P., M. K. Laubhan, and D. A. Hamilton. 1992. Forest structure associated with ruffed grouse abundance. Forest Ecology and Management 49:211-218. <http://www.ncbi.nlm.nih.gov/pubmed/8822306>.

Winfree, R., N. M. Williams, H. Gaines, J. S. Ascher, and C. Kremen. 2008. Wild bee pollinators provide the majority of crop visitation across land-use gradients in New Jersey and Pennsylvania, USA. Journal of Applied Ecology 45:793-802. 
Zimmerman, G. S., and R. J. Gutiérrez. 2007. The Influence of Ecological Factors on Detecting Drumming Ruffed Grouse. Journal of Wildlife Management 71:1765-1772. <http://www.bioone.org/doi/abs/10.2193/2006-184>.

Zimmerman, G. S., Ri. R. Horton, D. R. Dessecker, and R. J. Gutiérrez. 2013. New Insight to Old Hypotheses : Ruffed Grouse Population Cycles. THe Wilson Journal of Ornithology 120:239-247. 


\section{Chapter 2}

Ruffed Grouse Occupancy along Natural Gas Pipeline Right of Ways in Northern Pennsylvania

Formatted in the style of the Journal of Wildlife Management 


\title{
Ruffed Grouse Occupancy along Natural Gas Pipeline Right of Ways in Northern Pennsylvania
}

\begin{abstract}
Ruffed grouse (Bonasa umbellus) has seen populations declines in the Appalachian region due to loss of young forest habitat, which is necessary for cover and food resources. The region has also seen expansive development of the Marcellus shale for natural gas. Utilization of horizontal drilling necessitates pipeline construction for gas transport, which creates linear strips of herbaceous vegetation in otherwise forested areas. This study examined B. umbellus use of these pipeline right-of-ways (ROW) to identify beneficial attributes. Surveys for grouse were performed over the 2019 and 2020 field season at 80 sites, with transects perpendicular to each ROW. Too few grouse were observed to perform analysis. Incidental wildlife sightings of wild turkey (Meleagris gallopavo) and white-tailed deer (Odocoileus virginianus) on ROWs occurred more often than grouse, and indicate that ROWs can be beneficial to some wildlife species.
\end{abstract}

Keywords: Bonasa umbellus, natural gas, reclamation, ROW, ruffed grouse 


\section{Introduction}

Ruffed grouse (Bonasa umbellus) is a medium sized game bird common across the northern mountainous regions of North America (Bump et al. 1947). Grouse are predominantly forest birds, utilizing various age classes of forest for breeding, chick rearing, roosting, and foraging (Bump et al. 1947, Jones et al. 2008, Hansen et al. 2011). Previous studies have identified young forest habitat as a limiting factor for grouse populations that have declined in recent decades (Whitaker and Stauffer 2004, Tirpak et al. 2006, Jones et al. 2008). A lack of young forest habitat can be attributed to maturing forests, declines in timber harvest, and a reduction in small scale farming (Haulton 1999, Tirpak et al. 2010).

Natural gas development in the Appalachian region may provide an analogue for young forest habitat that grouse require. Following the first utilization of horizontal well drilling in Pennsylvania in 2004, the Marcellus and Utica shales have been drilled and hydraulically fractured to capture natural gas (Carter et al. 2011). Compared to conventional vertical wells, 216 unconventional horizontal wells can be co-located on a single well pad and can collect gas from a larger land area (Drohan et al. 2012, Zinkhan Jr. 2016). Underground pipelines are necessary to transport the large quantity of produced gas from well pads to storage and production facilities. Pipeline ROWs routed through agricultural areas are often replanted with crops, but those in forested areas cannot be replanted with trees until the pipeline is removed (Slonecker and Milheim 2015). To ensure pipeline integrity, Right of Way (ROW) vegetation is managed through chemical or mechanical means to exclude woody plants. ROW size will vary based on pipeline diameter and environmental permits, but is commonly between $10 \mathrm{~m}$ and $30 \mathrm{~m}$ (Zinkhan Jr. 2016). Because these ROWs must be maintained in an herbaceous sere, there is potential for these ROWs to benefit wildlife conservation. 
This study examined the extent to which ruffed grouse use natural gas pipeline ROWs and determined which attributes were associated with higher use. If ROWs can provide early successional habitat for ruffed grouse nesting or foraging areas for brood rearing, they may positively influence population growth. Use of ROW was assessed by walking transects and recording presence of grouse both on ROWs and in adjacent forest. I hypothesized that ruffed grouse use of reclaimed pipeline ROWs would be higher where ROW vegetation was taller and denser. Although a ROW alone is unlikely to provide a full range of habitat requirements, it may provide brood habitat near areas with young forest nesting habitat. I also predicted that ruffed grouse use of older pipelines would be higher than younger pipelines due to denser vegetation on the ROW and forest edges providing better brood cover and brood foraging habitat.

\section{Study Area}

Research was conducted on two land parcels managed by the State of Pennsylvania: the Tiadaghton State Forest and Game lands 12. These state-managed land parcels are within 100 $\mathrm{km}$ of the city of Williamsport, Pennsylvania and heavily forested (Fig. 2.1). North-Central Pennsylvania has seen extensive natural gas development following the development of horizontal drilling and hydraulic fracturing. These sites were chosen based on the quantity of gathering pipelines present and forest cover.

The Tiadaghton State Forest is administered by the Pennsylvania Department of Conservation and Natural Resources (DCNR) and encompasses 59,300 hectares (figure 2.2). This forest is located primarily in Lycoming County with some parcels extending into surrounding counties. Terrain includes steep mountains with cold mountain streams between them. Much of the ground cover is forest, and regular timber harvest does occur. The ridge-tops within the forest were 
primarily developed in 2012 and 2013 for natural gas extraction. Approximately $76 \mathrm{~km}$ of pipeline are present on the state forest to support 42 well pads and 254 wells as of 2018.

Game lands 12 (GL12) is approximately 10,350 hectares and administered by the Pennsylvania State Game Commission (Fig. 2.3). It is located Northwest of the Tiadaghton State Forest and is more contiguous than Tiadaghton State Forest. Natural gas development did not start until 2016 within the game lands, with the most recent pipeline completed in 2019. The southern trunk line is approximately $11 \mathrm{~km}$ long and was completed in 2016. The Northern pipeline is approximately $18 \mathrm{~km}$ long and was completed in 2019. The southern line supports 5 well pads and 32 permitted wells and the northern line supports 3 pads and 3 wells as of 2018 .

\section{Methods}

Site Selection

Pipelines on each site were hand digitized using publicly available National Agriculture Imagery Program (NAIP) imagery from 2007 to 2016 and well permit locations from the Pennsylvania DEP (PADEP 2018). The width, age, and reclamation plan for pipelines varied within and among sites. Eighty sites were located randomly along pipelines within the study areas (40 each on the Game lands and State Forest, respectively) at least 500 meters apart.

\section{Ruffed Grouse Surveys}

Flush count surveys were conducted for ruffed grouse four times between May and August 2019 and repeated in 2020 (eight total surveys) at each site. Flush counts were conducted along the same transect at each site, but direction of travel was random. Transects were $200 \mathrm{~m}$ in length, and oriented perpendicular to the pipeline ROW. Transects were centered on the ROW, 
with 100 meters on each side. Flush counts were performed without a dog, and one or two surveyors present. The GPS location of each flushed bird was recorded. All 80 sites were surveyed over four 2-week periods, with each site at least 10 days apart. Surveys were conducted between 07:30 and 16:00 in any weather except medium to heavy rain. Date, time of day, length of survey, temperature, wind speed, cloud level, and surveyor were recorded as detection variables for each survey.

Wildlife observed incidentally (not on a transect) were recorded separately. Incidental encounters included animals seen while driving to study sites along a pipeline and while walking to study sites. Animals were identified to the species level, sexed if possible, the number of individuals counted, and the presence of young recorded.

\section{Habitat Data}

Habitat metrics were measured on the ROW and in the surrounding forest. The width of the ROW and presence of a road adjacent to the ROW was recorded. Forestry measurements were taken at seven sampling locations along each transect: ROW center, each ROW edge, 20 meters from each edge, and both ends of the transect (100 m from ROW center). At each location, woody stems were counted within two mil-acre plots (approx. $4.05 \mathrm{~m}^{2}$ ) and placed into size classes based on diameter at breast height: $<24 \mathrm{~mm}, 25 \mathrm{~mm}-76 \mathrm{~mm}, 77 \mathrm{~mm}-152 \mathrm{~mm}$, and $>153 \mathrm{~mm}$. All trees within $10 \mathrm{~m}$ of plot center at each sampling location were identified to species and the diameter at breast height measured using a Biltmore Stick. Canopy height and canopy cover were measured using a Bushnell laser rangefinder and spherical densiometer, respectively. 


\section{Data Analysis}

Ruffed grouse use of ROWs was quantified by modeling occupancy at the study sites. Weather variables recorded at the start of each survey were used to account for imperfect detection, and habitat metrics were used as covariates to predict occupancy.

\section{Results}

A total of five grouse were observed during transect surveys in 2019 and 2020. Four were recorded in 2019 at 3 separate field sites and 1 in 2020 at 1 field site. The site in which a grouse was observed in 2020 was also a site where a grouse was observed in 2019. In total, grouse were observed at 3 field sites, 2 of which were on the Game Lands 12 and one was on the Tiadaghton State Forest. All grouse observed were single individuals without broods in wooded areas off the ROW $(30 \mathrm{~m}+)$. All the sites where grouse were observed had been clear-cut within the previous 10 years and show characteristics of a young forest. Ruffed grouse occupancy was not analyzed due to insufficient data. Lack of standardization between travel among sites precluded the analysis of incidental observations.

Eastern wild turkeys (Meleagris gallopavo) were observed more frequently on transects than ruffed grouse. They were observed 4 times in 2019 and 2 times in 2020 during surveys. In 2019, 3 of the sites where turkeys were found were on the game lands and one on the state forest site. One of the turkeys was observed with polts during the $4^{\text {th }}$ survey in late July. Two turkeys were observed during 2020 surveys, both on the state forest site. One female was observed with polts foraging on the ROW. Turkeys observed during surveys were never seen multiple times at the same site. 
Incidental observations

Seven different species were observed on 131 occassions on ROWs while traveling to survey sites or otherwise not actively surveying, with a total of 241 individuals observed. Recorded species included eastern wild turkey, white tailed deer (Odocoileus virginianus), American black bear (Ursus americanus), mallard duck (Anas platyrhynchos), striped skunk (Mephitis mephitis), North American porcupine (Erethizon dorsatum), and timber rattlesnake (Crotalus horridus) (Table 2.1). The ducks were observed in artificial wetlands adjacent to the ROW, which were constructed as part of the ROW reclamation. Turkey and deer were observed more often on the game lands site than the Tiadaghton State Forest. Other small mammals (squirrels) and songbirds were also observed but not recorded.

\section{Discussion}

The low grouse encounter frequency - five grouse during 640 surveys -- precluded any meaningful statistical analysis on their use of pipeline ROW. Low detection rates are an acknowledged issue with ruffed grouse due to a lack of vocalizations, cryptic coloring, and small size (Devers et al. 2007, Whitaker et al. 2007, Zimmerman and Gutiérrez 2007). Sampling protocol could be adjusted to improve the number of encounters by incorporating dogs, surveying more often, surveying longer distances, or surveying at different times of the year. There is evidence to suggest that ruffed grouse densities in the study area have recently declined due to habitat degradation and disease. West Nile Virus has been suspected to suppress ruffed grouse populations in Pennsylvania irrespective of local habitat quality (Stauffer et al. 2018). The Pennsylvania Game Commission conducts annual drumming counts to estimate of grouse abundance as part of a long-term study. Drumming count data for the Game Lands 12 from April 
2019 reported no drumming males, whereas they had been in previous years (PA Game

Commission, personal comm.). This provides further evidence that the local population may be small and difficult to detect.

Assuming a very limited number of grouse occupy the study sites, our design lacked the necessary rigor to assess their use of ROW. There are areas of mature forest on both study sites that have been recently clear cut to create young forest habitat for grouse adjacent to the ROW. All grouse observed during surveys were seen in these young forest areas with high stem densities. Some of these harvests were recent - within 2 years of the survey, which is too young to create the young forest conditions often selected by grouse (Jones et al. 2008). The data collected do not provide evidence to support the assertion that pipeline ROWs can provide young forest habitat for ruffed grouse. There is, however, some evidence that ROWs can be planted to provide food resources for a variety of wildlife.

The high number of incidental wildlife encounters is evidence that some types of wildlife use ROWs for foraging. Deer and turkeys were often observed foraging on ROWs. The nonstandardized way that these encounters occurred precludes any meaningful analysis on differences between ROWs and encounter rates. There was no effort to ensure road travel was consistent throughout the field season, or that each road was surveyed an equal number of times or at a variety of times of the day. These factors incorporate potential bias into the data and fail the assumptions of random sampling necessary for statistical analysis. In some areas, there was heavy truck traffic present along ROW roads because of ongoing well drilling and maintenance. From our recorded encounters, all types of wildlife quickly moved away from vehicles on the road. There is no way to account for how many animals were flushed from the ROW due to truck traffic before they were encountered or how many trucks traveled on the ROWs each day. 


\section{Literature Cited}

Bump, G., R. W. Darrow, F. C. Edminster, and W. F. Crissey. 1947. The ruffed grouse: life history, propogation, and management. Telegraph Press, Harrisburg, Pennsylvania.

Carter, K. M., J. A. Harper, K. W. Schmid, and J. Kostelnik. 2011. Unconventional natural gas resources in Pennsylvania: The backstory of the modern Marcellus Shale play. Environmental Geosciences 18:217-257.

Devers, P. K., D. F. Stauffer, G. W. Norman, D. E. Steffen, D. M. Whitacker, J. D. Sole, T. J. Allen, S. L. Bittner, D. A. Buehler, J. W. Edwards, D. E. Figert, S. T. Friedhoff, W. W. Giuliano, C. A. Harper, W. K. Igo, R. L. Kirkpatrick, M. H. Seamster, H. A. Spiker, D. A. Swanson, and B. C. Tefft. 2007. Ruffed Grouse Population Ecology in the Appalachian Region. Wildlife Monographs 168:1-36. <http://doi.wiley.com/10.2193/0084-0173.168>.

Drohan, P. J., M. Brittingham, J. Bishop, and K. Yoder. 2012. Early trends in landcover change and forest fragmentation due to shale-gas development in Pennsylvania: A potential outcome for the northcentral appalachians. Environmental Management 49:1061-1075.

Hansen, C. P., J. J. Millspaugh, and M. A. Rumble. 2011. Occupancy modeling of ruffed grouse in the Black Hills National Forest. Journal of Wildlife Management 75:71-77.

Haulton, G. S. 1999. Ruffed Grouse Natality, Chick Survival, and Brood Micro-Habitat Selection in the Southern Appalachians. Virginia Polytechnic Institute and State University.

Jones, B. C., J. L. Kleitch, C. A. Harper, and D. A. Buehler. 2008. Ruffed grouse brood habitat use in a mixed hardwood forest: Implications for forest management in the Appalachians. Forest Ecology and Management 255:3580-3588.

PADEP. 2018. Issued Gas Well Permits. Pennsylvania Department of Environmental Protection. <http://www.depreportingservices.state.pa.us/ReportServer/Pages/ReportViewer.aspx?/Oil_ Gas/Permits_Issued_Detail>.

Slonecker, E., and L. Milheim. 2015. Landscape Disturbance from Unconventional and Conventional Oil and Gas Development in the Marcellus Shale Region of Pennsylvania, USA. Environments 2:200-220. <http://www.mdpi.com/2076-3298/2/2/200/>.

Stauffer, G. E., D. A. W. Miller, L. M. Williams, and J. Brown. 2018. Ruffed grouse population declines after introduction of West Nile virus. Journal of Wildlife Management 82:165-172.

Tirpak, J. M., W. M. Giuliano, T. J. Allen, S. Bittner, J. W. Edwards, S. Friedhof, C. A. Harper, W. K. Igo, D. F. Stauffer, and G. W. Norman. 2010. Ruffed grouse-habitat preference in the central and southern Appalachians. Forest Ecology and Management 260:1525-1538. Elsevier B.V. <http://dx.doi.org/10.1016/j.foreco.2010.07.051>.

Tirpak, J. M., W. M. Giuliano, C. A. Miller, T. H. Allen, S. Bittner, D. A. Buehler, J. W. Edwards, C. A. Harper, W. K. Igo, G. W. Norman, M. Seamster, and D. F. Stauffer. 2006. Ruffed grouse population dynamics in the central and southern Appalachians. Biological Conservation 133:364-378.

Whitaker, D. M., and D. F. Stauffer. 2004. Ruffed grouse (Bonasa umbellus) habitat ecology in the central and southern Appalachians. ProQuest Dissertations and Theses 220 p. 
<http://ezproxy.usherbrooke.ca/login?url=http://search.proquest.com/docview/305105487?a ccountid=13835 L2 - http://sfxhosted.exlibrisgroup.com/sherbrooke?url_ver=Z39.88-

2004\&rft_val_fmt=info:ofi/fmt:kev:mtx:dissertation\&genre=dissertations+\%26+theses\&sid $=\mathrm{P}>$.

Whitaker, D. M., D. F. Stauffer, G. W. Norman, P. K. Deversa, J. Edwards, W. M. Giuliano, C. Harper, W. Igo, J. Sole, H. Spiker, and B. Tefft. 2007. Factors associated with variation in home-range size of appalachian ruffed grouse (bonasa umbellus). The Auk 124:1407-1424.

Zimmerman, G. S., and R. J. Gutiérrez. 2007. The Influence of Ecological Factors on Detecting Drumming Ruffed Grouse. Journal of Wildlife Management 71:1765-1772. <http://www.bioone.org/doi/abs/10.2193/2006-184>.

Zinkhan Jr., F. 2016. Site Characteristics Associated with Conventional and Unconventional Petroleum Development in West Virginia. West Virginia University. 


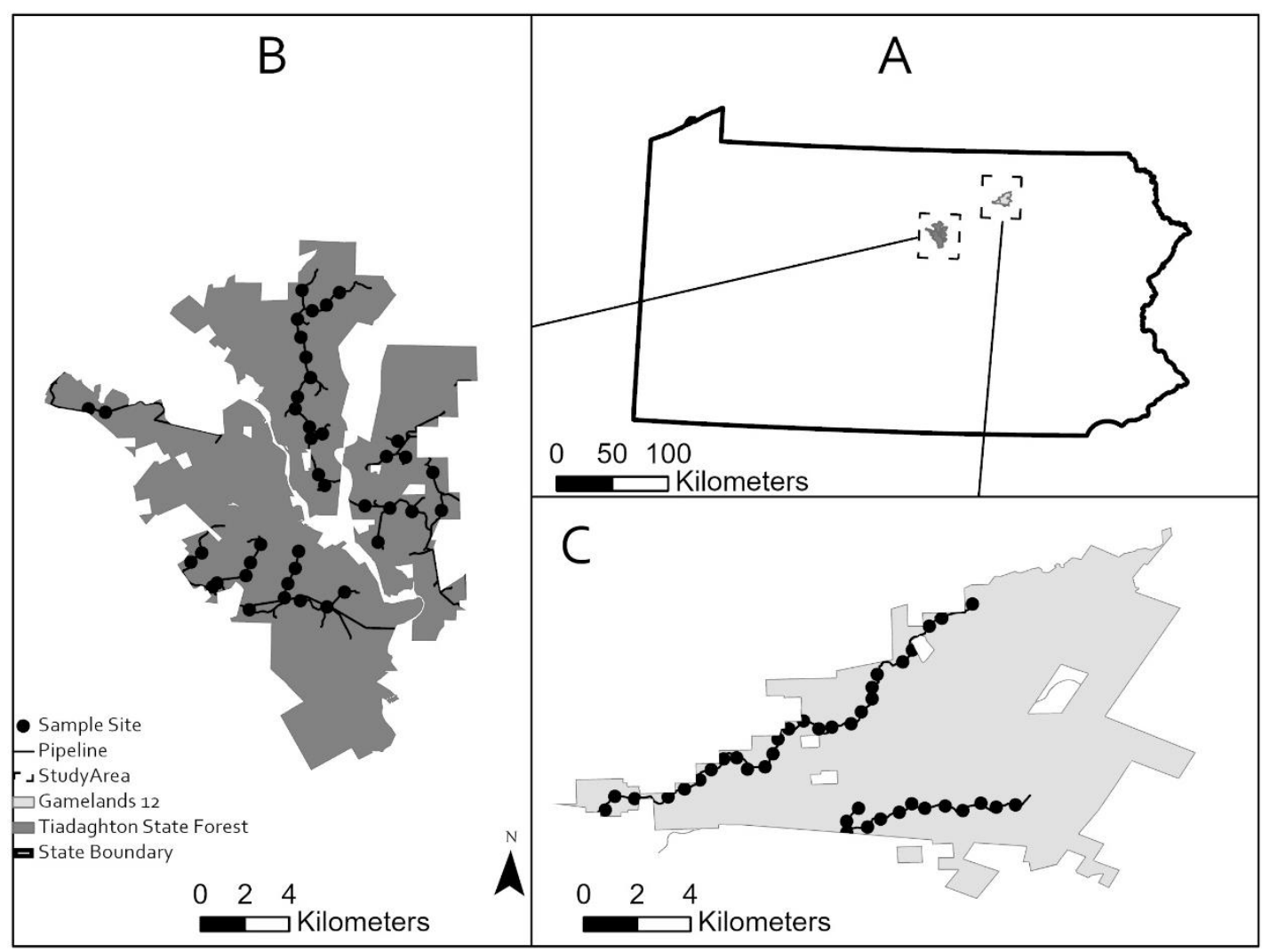

Figure 2.1: Location of main study sites in Pennsylvania (A). Site B is the Tiadaghton State Forest while C is PA state game lands 12. Study sites located on Pennsylvania Game Commission game lands 12.80 sample sites are evenly distributed between A and B. All pipelines in the Tiadaghton State Forest were constructed in 2013. There are 2 pipelines within the game lands site, the North-Western line completed in 2019 and the South-Eastern line completed in 2017. 
Table 2.1: Incidental wildlife observations along natural gas ROWs in the Tiadaghton State Forest and Game Lands 12 of Pennsylvania. Observations were recorded while driving or walking along ROWs but not actively surveying. Data are combined from 2019 and 2020 surveys (May-August).

\begin{tabular}{|c|c|c|c|c|}
\hline Species & Total Observations & Broods/ Young & Game lands 12 & Tiadaghton State Forest \\
\hline Eastern Wild Turkey (Meleagris gallopavo) & 133 & 8 & 90 & 43 \\
\hline White Tailed Deer (Odocoileus virginianus) & 91 & 6 & 70 & 21 \\
\hline Mallard Duck (Anas platyrhynchos) & 4 & 0 & 4 & 0 \\
\hline Striped Skunk (Mephitis mephitis) & 1 & 0 & 0 & 1 \\
\hline North American Porcupine (Erethizon dorsatum) & 1 & 0 & 1 & 0 \\
\hline
\end{tabular}




\section{Chapter 3:}

Influence of natural gas pipeline right of ways on occurrence of amphibians and reptiles in an Appalachian forest 
Formatted for submission to the journal of Forest Ecology and Management

\title{
Title: Influence of natural gas pipeline right of ways on occurrence of amphibians and reptiles in an Appalachian forest
}

\begin{abstract}
:
Increased exploitation of the Marcellus Shale in the Appalachian region for natural gas extraction has highlighted concerns about the effects of the associated pipeline infrastructure on wildlife in forested areas. Previous studies have shown that roads and other linear infrastructure negatively affects amphibians through edge effects yet can improve habitat quality for snakes. I investigated occurrence dynamics of amphibians and reptiles in relation to natural gas pipeline right of ways (ROW) in northern Pennsylvania, focusing on the influence of pipeline age, distance from a ROW, and habitat structure. I sampled amphibians and reptiles using cover boards placed along a gradient from ROW to interior forest. I detected 3 salamander species and 6 snake species during the study. Snakes were found on ROWs with higher frequency than salamanders, likely due to increased ability to thermoregulate or more abundant food resources. For the eastern red-backed salamander (Plethodon cinereus), occupancy probability increased as distance from the ROW increased and decreased as pipeline age increased. Canopy cover was the most supported habitat structure predictor for $P$. cinereus, with occupancy increasing as canopy cover increased. These findings suggest that pipelines should be located along existing disturbance or in young forest areas to limit impacts to terrestrial salamanders, while still providing benefits for snakes.
\end{abstract}

Keywords: Natural gas, pipeline, Plethodon cinereus, right of way, ROW, salamander, snake 


\subsection{Introduction}

Natural gas extraction in the Appalachian region changed dramatically with the development of horizontal drilling and hydraulic fracturing in 2004 (Carter et al. 2011, Slonecker et al. 2012). Energy producers were able to extract a larger volume of gas from drilled wells and could access shale deposits farther under the surface compared with vertical wells (Carter et al. 2011). Pipelines are the primary method of conveyance for extracted gas from source to market, and necessitate land clearing through forested areas. Pipelines routed through agricultural areas can be replanted with crops, but in forested areas the right of way (ROW) must be maintained as herbaceous ground cover. Pipelines in forested areas are often co-located with existing roads to make construction easier, although existing roads are expanded and improved to handle large truck traffic necessary for hydraulic fracturing (Langlois et al. 2017). A pipeline routed through forested areas thus decreases forest cover, and has been found to contribute to forest fragmentation (Drohan et al. 2012, Slonecker et al. 2012).

Forest fragmentation due to roads, pipelines, and powerlines has varying influence on wildlife. Wildlife is primarily influenced by sensitivity to microclimatic conditions (Murcia 1995a, Fischer and Lindenmayer 2007). Compared to interior forest understory, edges have higher temperatures and drier soils from increased sun exposure and wind (Phillips and Shure 1990, Murcia 1995a, Chen et al. 1999). These impacts vary in intensity based on aspect and opening width, with southwestern slopes showing the highest effect and northeast the least (Marsh 2007, Moseley et al. 2009). As opening width increases, the duration of exposure to direct solar radiation increases, leading to higher temperatures and drier soil conditions (Phillips and Shure 1990). The extent to which these microclimatic changes effect a wildlife species depend on the physiological constraints of that species. 
Forest fragmentation negatively impacts forest salamanders by reducing habitat quality, limiting population connectivity, and increasing mortality events (Demaynadier and Hunter 1998, Marsh et al. 2005, Marsh 2007) Edge effects along forest openings decrease habitat quality by increasing desiccation risk at the surface (Demaynadier and Hunter 1998, Semlitsch et al. 2007). Salamanders have lower occupancy along forest edges as a result of these effects, with occupancy decreasing in the years following edge creation (Gibbs 1998, Knapp et al. 2003, Macneil and Williams 2014). It can take upwards of 30 years following a clear-cut for salamander populations to return to pre-harvest levels (Macneil and Williams 2014). Linear fragmentation from roads and ROWs also creates barriers to dispersal for individuals due to inhospitable microclimatic conditions (Marsh et al. 2005, 2008, Marsh 2007). Populations in isolated forest patches with poor connectivity become more susceptible to local extinction events (Andrews et al. 2008). Forest roads open to traffic had lower occupancy than gated roads, suggesting that road traffic may also increase mortality in addition to creating a dispersal barrier (Marsh 2007). In all cases, the magnitude of negative effects increases as the width of forest opening increases (Demaynadier and Hunter 1998, Marsh 2007, Macneil and Williams 2014). There are no documented benefits from linear forest disturbance for terrestrial forest salamanders such as the eastern red back salamander (Plethodon cinereus).

Snakes have higher tolerances to temperature and lack of moisture, making them less susceptible than salamanders to the microclimatic changes caused by edge effects (Reinert 1993). Surveys along a 50-year old powerline ROW in Pennsylvania showed higher snake species richness on the ROW than in surrounding forests (Yahner 2004). Generalist snake species use edges more often than interior forests, with increased prey abundance and improved 
thermoregulation being hypothesized mechanisms (Weatherhead and Charland 1985, Patrick and Gibbs 2009). For timber rattlesnakes (Crotalus horridus), meadow voles (Microtus pennsylvanicus) are a prey species that is more abundant in field habitat than forest habitats, suggesting that prey abundance on ROWs would be higher for this species (Manson et al. 1999, Clark 2002). In contrast to salamanders, increased solar radiation in forest openings enable snakes to thermoregulate more effectively than on the forest floor (Reinert 1993).

This study surveyed for salamanders and snakes along natural gas pipeline ROWs, focusing on how ROW age and the distance from a ROW influence occupancy. Although previous research has looked at the effects of clear cuts and roads on salamanders and snakes, there are few data available for pipeline ROWs specifically. Although pipeline ROWs with cutback borders have been shown to minimize negative effects on forest salamanders, they were not used on ROWs in this study (Margenau 2020). While powerline corridors are similar, differences in vegetation management suggest that microclimatic conditions, and their corresponding effects on wildlife, may differ between them. With pipelines expected to have lifetimes up to 30 years before restoration, it is important to know how these relatively new types of disturbance impact forest snakes and salamanders (Carter et al. 2011). Comparing pipeline ROWs of varying ages highlighted how effects may differ throughout time. Forest structure surrounding cover boards was also measured to identify areas of low occupancy, which would be preferable for pipeline routing in a least-harm scenario. Plethodon cinereus was used as a case study to represent woodland salamanders in the study area due to its abundance. I expected that salamander occupancy would increase as both age and distance from the ROW increased due to diminishing edge effects (Demaynadier and Hunter 1998, Gibbs 1998, Marsh and Beckman 2004). Snake occupancy is expected to have an inverse relationship with distance from ROW edge, since 
ROWs are expected to provide solar radiation for temperature regulation and prey resources (Weatherhead and Charland 1985, Yahner 2004, Carfagno and Weatherhead 2006, Reinert et al. 2011). As ROW age increases, I expect vegetation on the ROW and edges to be larger and denser than newly reclaimed ROWs. This is expected to both shield the ground surface from solar radiation and provide better cover for prey than new ROWs. Areas with forest structure representative of mature forest (high canopy cover and large trees present) are expected to have higher occupancy than recently harvested areas due to differences in temperature and moisture at the ground surface.

\subsubsection{Study Site}

The study area included two land parcels managed by the State of Pennsylvania: the Tiadaghton State Forest and Game Commission Game lands 12 (figure 3.1). These statemanaged land parcels are within $100 \mathrm{~km}$ of the city of Williamsport and heavily forested. Average annual temperatures range from $1-13^{\circ} \mathrm{C}$, and annual precipitation is $305 \mathrm{~cm}$ including snowfall. The dominant forest type is northern hardwood, with American beech (Fagus grandifolia), red maple (Acer rubrum), black cherry (Prunus serotina), white oak (Quercus alba), chestnut oak (Quercus montana), white pine (Pinus strobus), and eastern hemlock (Tsuga canadensis) being most common. Study sites were chosen based on the quantity of gathering pipelines present and forest cover. Pipelines were hand digitized using publicly available National Agriculture Imagery Program (NAIP) Imagery from 2007 to 2016 and well permit locations from the Pennsylvania Department of Environmental Protection (PADEP 2018). The width, age, and reclamation plan for pipelines varied within and among sites. Eighty sites were located randomly along pipelines within the study areas (40 each on the Game lands and State Forest, respectively) and at least 500 meters apart. 
The Tiadaghton State Forest is administered by the Pennsylvania Department of Conservation and Natural Resources (DCNR) and encompasses 59,300 hectares (Figure 3.1). This forest is located primarily in Lycoming County with some parcels extending into surrounding counties. Terrain includes steep mountains with cold mountain streams between them. Much of the ground cover is forest, and regular timber harvest does occur. The ridge-tops within the forest were primarily developed in 2012 and 2013 for natural gas extraction. Approximately $76 \mathrm{~km}$ of pipeline are present on the state forest to support 42 well pads and 254 wells as of 2018.

Game lands 12 (GL12) is approximately 10,350 hectares and administered by the Pennsylvania State Game Commission (Figure 3.1). It is located Northwest of the Tiadaghton State Forest, and is a more contiguous patch of land. Natural Gas development did not start until 2016 within the game lands, with the most recent pipeline completed in 2019. The southern trunk line is approximately $11 \mathrm{~km}$ long and was completed in 2016 . The Northern pipeline is approximately $18 \mathrm{~km}$ long and was completed in 2019. The southern line supports 5 well pads and 32 permitted wells and the northern line supports 3 pads and 3 wells as of 2018 .

\subsection{Materials and Methods}

\subsubsection{Sampling protocol}

Reptiles and amphibians have historically been surveyed using natural cover object searches, artificial cover boards (of various materials), and drift fences with pitfall or funnel traps (Grant et al. 1992). Natural cover object searches are dependent on the presence of cover objects, which were absent along the pipeline sites. Within the study areas, all coarse woody debris from 
tree clearing was removed from the site during construction. Using cover boards eliminated the issue of finding natural cover objects, allowed search effort to remain constant among sites and surveys, and have been used successfully in previous studies (Moore 2005, Hesed 2012). Cover boards were deployed during June and July 2019, and surveyed four times from May to August 2020 with at least 10 days between surveys. Boards that were found to be missing in 2020 were not be replaced, as there was be no way to replicate the "seasoning time" required for animals to find and begin using them. It is assumed that missing boards did not affect occupancy at the site level. Encountered animals were identified to the species level.

I deployed two types of cover boards to sample for reptiles and amphibians independently. Untreated $60^{\times} 60^{\times} 1.27-\mathrm{cm}$ plywood boards were placed to survey for reptiles

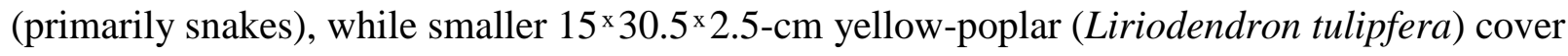
boards were used to survey for salamanders and other amphibians. A 6-board array of $15^{\times} 30.5^{\mathrm{x}}$ 2.5-cm untreated poplar boards was placed adjacent to the larger $60 \times 60 \times 1.27-\mathrm{cm}$ plywood to survey the same location for both types of wildlife. Boards were placed at the center of each ROW, at the edge of the ROW, and perpendicular to the ROW at distances of $10 \mathrm{~m}$ past the edge of the ROW and 30m past the edge of the ROW at each study site (Figure 3.2). These distances were chosen to allow comparison between the ROW (converted habitat) and a forest free of edge effects (30m from edge). The edge and 10-m cover boards, in conjunction with the ROW and 30$\mathrm{m}$ boards, provide data along a forest edge gradient from non-forest through to "unfragmented forest" that is free from edge effects. If a road was present adjacent to the ROW, boards were always placed on the opposite side of the ROW from the road. Placement of boards off the ROW will be perpendicular to the ROW. At each of these 4 placement locations, one $60 \times 60 \times 1.27-\mathrm{cm}$ plywood board and $615^{\times} 30.5 \times 2.5$-cm boards were set out $2 \mathrm{~m}$ apart, parallel to the ROW itself 
(Figure 3.2). For each study site, there were 4 plywood and 24 poplar boards deployed in total. Accounting for all survey sites, a grand total of $32060^{\times} 60^{\times} 1.27-\mathrm{cm}$ plywood boards and 1920 $15^{\times} 30.5 \times 2.5-\mathrm{cm}$ poplar boards will be deployed, resulting in a survey area of $208 \mathrm{~m}^{2}$.

\subsubsection{Site and survey variables}

Site variables included ROW- level characteristics that were recorded in 2019 at the time cover boards were deployed (Table 3.2). At each sampling site, I identified the age of the associated pipeline using environmental plans obtained from the Pennsylvania Game Commission and Department of Conservation and Natural Resources. Publicly available NAIP imagery was used to verify these dates. For each coverboard set, I recorded distance to ROW center and collected several habitat structure measurements. The quantity of woody stems in size classes of $<2.54 \mathrm{~cm}, 2.55-7.62 \mathrm{~cm}$, and $7.63 \mathrm{~cm}-15.24 \mathrm{~cm}$ was recorded within two $4.04 \mathrm{~m}^{2}$ plots, and the counts averaged for a single count of each size class at each cover board location. Canopy cover was recorded at each cover board site using a spherical densitometer, and canopy height was measured using a Bushnell laser rangefinder. Within 10m of each cover board location, the number and basal area of trees with a diameter at breast height larger than $15.24 \mathrm{~cm}$ was also recorded.

Survey variables were recorded at the start of each survey, including: temperature $\left({ }^{\circ} \mathrm{C}\right)$, time of day, date, windspeed (m/s), survey duration (min), and precipitation (Table 3.1). Temperature and windspeed were recorded in the shade at breast height, and averaged over a 2 minute period. A kestrel 2000 weather station was used to record temperature and windspeed. Weather conditions were recorded as a categorical value, with no surveys performed in heavy rain (0 - full sun, 1 - partly cloudy, 2 - overcast, 3 - light rain, 4 - medium rain). 


\subsubsection{Chi Square Analysis}

Frequency of observations for snakes and non- $P$. cinereus salamanders were too low to perform advanced statistical analyses. Chi square analysis was performed on pooled data for all snakes observed and all non- $P$. cinereus salamanders to test the independence of observations on different age classes to coverboard distance from the ROW.

\subsubsection{Occupancy Model Analysis}

A single-season occupancy model was used to model $P$. cinereus occupancy at each cover board site, assuming a closed population for the duration of sampling (Bailey et al. 2004). An a-priori model set including all detection variables individually, a model including all time related variables, a model including all weather-related variables, and a full model with all variables was tested to account for the imperfect detection of terrestrial salamanders. Model support was ranked using Akaike's Information Criterion corrected for small sample size (AICc), and models within $2 \Delta \mathrm{AIC}$ of the top model were considered to have considerable support, and models within $7 \Delta$ AIC to have moderate support (Akaike 1973, Burnham et al. 2011). Beta coefficients from top models whose $85 \%$ confidence levels did not overlap zero are characterized as having strong effects on detection (Arnold 2010). Top supported detection models were carried through the remainder of occupancy modeling of $P$. cinereus.

The effect of cover board distance from the ROW and ROW age on $P$. cinereus occupancy was modeled independently of other site level covariates to isolate the effects of these factors. A model set composed of four models was ranked using AICc: ROW age alone, distance from ROW, age + distance, and age * distance. Model support was ranked using AICc, and models within $2 \Delta \mathrm{AIC}$ of the top model were considered to have considerable support, and 
models within $5 \Delta \mathrm{AIC}$ to have moderate support. Model averaged beta coefficients whose $95 \%$ confidence levels did not overlap zero are characterized as having strong effects on occupancy.

Site level forest characteristics were modeled to identify variation in occupancy based on forest structure. Due to high correlation between all covariates, model selection was performed with each covariate modeled individually. Model support was ranked using AICc, and models within $2 \triangle \mathrm{AIC}$ of the top model were considered to have considerable support, and models within $5 \Delta \mathrm{AIC}$ to have moderate support. Model averaged beta coefficients whose $85 \%$ confidence levels did not overlap zero are characterized as having strong effects on occupancy (Arnold 2010).

\subsection{Results}

\subsubsection{Species encounters}

Three species of salamanders were encountered: eastern red-back salamander (Plethodon cinereus), eastern newt eft stage (Notophthalmus viridescens), and northern slimy Salamander (Plethodon glutinosus). Captures per unit effort (CPUE) of $P$. cinereus were much higher than the other salamander species (Table 3.3). A chi square analysis of non- $P$. cinereus salamander testing the independence of ROW age and cover board distance from the ROW showed no evidence of variable dependence $\left(\chi^{2}=2.3906, \mathrm{df}=6, \mathrm{p}=0.885\right)$.

The small number of snakes encountered prevented occupancy modeling, even when all species were pooled. Six species of snake were observed 28 times during cover board searches: Eastern garter snake (Thamnophis sirtalis), ringed-neck snake (Diadophis punctatus), Northern brown snake (Storeria dekayi), Eastern milk snake (Lampropeltis trangulum), Northern redbelly 
snake (Storeria occipitomaculata), and the Smooth green snake (Opheodrys vernalis). Snakes were found under plywood more commonly than poplar arrays, and more often in ROWs than interior forest. Capture per unit effort was lower for snakes than P. cinereus (Table 3.3). A chi square test of independence between ROW age and cover board distance from the ROW did not show evidence of dependence between these factors $\left(\chi^{2}=6.981, \mathrm{df}=6, \mathrm{p}=0.3219\right)$.

\subsubsection{Modeling results}

P. cinereus detection

Air temperature was the best supported predictor of $P$. cinereus detection $(\beta=-0.145$, $85 \%$ CI (-0.19132, -0.09952)). Detection probability decreased as temperature increased (Figure 3.3). The $\triangle$ AIC between the top models (temperature, temperature ${ }^{2}$ ) was 1.18 , with models having an Akaike weight of 0.64 and 0.36, respectively. Occupancy model sets were ranked using both top models, although models using temperature ${ }^{2}$ were never ranked higher than the same model using temperature alone. Only the temperature model was carried through to the remaining modeling based on the support it had relative to other detection models.

ROW distance and Age

Modeling results of ROW distance and ROW age show that distance is a better supported predictor than age when modeled alone. The top model, however, included both covariates with an interactive effect (Table 3.5). Predicted from the top model, occupancy probability decreased as age increased and increased as distance from the ROW increased (Figure 3.4). Confidence intervals for the beta coefficient of age did overlap 0 , however. The effect of distance from the ROW edge on predicted occupancy did differ with ROW age. As age increased, predicted occupancy probability at all distances from the ROW edge decreased (Figure 3.4). 
Forest Characteristics

Canopy cover at each coverboard site was the top supported model, although models including stem count $2.54-7.62 \mathrm{~cm}$, tree count, and tree basal area also had moderate support (within $5 \triangle \mathrm{AIC}$ ) (Table 3.4). Predicted occupancy probability increased $(\beta=0.021, \mathrm{SE}=0.01$, 85\% CI 0.011, 0.031) as the percent of canopy cover increased (Figure 3.5). Predicted occupancy increased $(\beta=14.39, \mathrm{SE}=23.71,85 \% \mathrm{CI}-32.09,60.87)$ as stem count $2.54-7.62 \mathrm{~cm}$ increased, although the standard error was large, and confidence intervals overlapped zero. Tree basal area was positively related to occupancy probability $(\beta=0.02, \mathrm{SE}=0.01,85 \% \mathrm{CI} 0.01,0.03$ ) (Figure 3.5). Predicted occupancy probability was expected to increase $(\beta=0.22, \mathrm{SE}=0.08,85 \% \mathrm{CI}$ $0.05,0.38)$ as tree count increased (Figure 3.5).

\subsection{Discussion}

$P$. cinereus occupancy increasing as the distance from the ROW edge increased is consistent with other salamander studies examining forest fragmentation (Silva et al. 2003, Bailey et al. 2004, Marsh and Beckman 2004, Semlitsch et al. 2007, Brannon et al. 2014, O'Donnell et al. 2014). The edge effects of increased sunlight penetration and wind that create a warmer and more arid forest floor are diminished as distance from a forest edge increases (Wright et al. 2010). ROW age having a negative relationship with occupancy suggests that these edge effects along ROWs may decrease habitat quality such that occupancy decreases over time. Changes in predicted occupancy at all distances from the forest edge as age increases is evidence of this degradation. Additionally, these results suggest that edge effects at the study site are influencing adjacent forest for at least 30m from each edge. In an interior forest free of edge effects, there should be no change in occupancy with respect to the age of nearby disturbance 
(DeGraaf and Yamasaki 2002, Semlitsch et al. 2007). I hypothesize that the youngest pipeline ROW (aged 1 year at time of survey) has higher occupancy because edge effects have not yet degraded $P$. cinereus habitat along the ROW to the extent of the older ROWs. As found in studies examining occupancy near clear cuts, predicted occupancy decreased over time following timber harvest rather than decreasing immediately and remaining constant (Demaynadier and Hunter 1998, Macneil and Williams 2014). I hypothesize that occupancy persists along recent edges due to remnant individuals, but no recolonization occurs after they perish. These impacts suggest that locating future pipelines along existing roads is a best management practice, as linear disturbance in the region has been found to negatively impact terrestrial salamanders (Kiviat 2013, Brand et al. 2014, Moran et al. 2015). Siting in both study areas followed this practice, and these results support that as worthwhile. Expanding the width of an existing road is preferable to creating additional clearings through interior forest patches free of edge effects, because new disturbance will degrade the quality of interior forest, decrease forest cover, and increase forest fragmentation (Murcia 1995b, Moran et al. 2015).

Forest structure covariates canopy cover, tree basal area, and tree count as the best supported predictors of occupancy is consistent with previous studies modeling $P$. cinereus occupancy in forested areas (DeGraaf and Yamasaki 2002, Marsh 2007, Moseley et al. 2009). These factors are indicative of a mature forest, and based on these results and the literature, mature forests with high percent canopy cover should be avoided where possible during pipeline planning. Areas of young forest already have lower $P$. cinereus occupancy than mature forests, and therefore locating pipelines through these areas would limit impacts to populations in less fragmented patches of mature forest. 
Counter to the results of the salamander surveys, snakes were more commonly found on ROWs than far from it. One mechanism for this difference is lower susceptibility to desiccation from increased temperature and lower moisture on the ROW than Plethodontids (O’Donnell et al. 2014). Another hypothesis is increased food availability on the ROW in the form of invertebrates and small mammals (Yahner 2004). A study on reptile and amphibian presence on a 50-year -old powerline ROW in Pennsylvania found that snake species richness was higher on the ROW than in surrounding forest (Yahner 2004). A timber rattlesnake skin was found under a ROW plywood board, but no live timber rattlesnakes were observed under cover boards. Evidence of meadow vole (Microtus pennsylvanicus) nests or live individuals were observed under 63 of 80 ROW plywood cover boards. That large numbers of ROW cover boards were used by meadow voles along the study area ROWs is evidence of an abundant food resource for $C$. horridus that was not observed beneath interior cover boards. Incidental sightings of $C$. horridus were common in the study area, indicating their presence on the landscape despite no observations during surveys. Rock structures were built on ROW edges during reclamation in the study area to provide hibernacula habitat for C. horridus and other species (Stauffer 2016). Additional research specifically targeted at large snakes and these structures may provide better evidence of ROW benefits for snake populations than what was found here.

In addition to providing rock structures to ROWs for snakes, there are opportunities to examine construction techniques that may limit the negative effects of ROW fragmentation on salamander populations. On all the ROWs that I surveyed, all woody debris or timber was removed from the work area. This was most likely done for ease of construction and pipeline maintenance, but woody debris could be added to the temporary workspace post-reclamation. Coarse woody debris has been found to improve salamander habitat quality when canopy cover 
is removed and surveys of powerline ROWs with coarse woody debris have found salamanders utilizing these objects (Brannon et al. 2014, O’Donnell et al. 2014). This debris would act as cover and refugia for amphibians and reptiles that may be traveling across the ROW, and may increase travel across what are sometimes population barriers (Marsh et al. 2005). The technology also exists to drill holes horizontally and install a pipeline underneath a land feature without disrupting the surface, called horizontal directional drilling (Allouche et al. 2000). This is most often done near water features and major roads to minimize surface disturbance. This method is much more costly than traditional pipeline trenching, but if used sparingly could preserve connectivity between amphibian populations across ROWs (Allouche et al. 2000). Much like travel corridors built above highways for ungulates and other mammals, portions of the ROW where the surface was not disturbed could promote connectivity of populations between forest patches.

\subsection{Conclusions}

P. cinereus occupancy along pipeline ROWs was most influenced by the distance from a ROW edge, following results of previous research about the negative impacts of forest edge effects on terrestrial salamanders. Snakes were found more often on ROWs than off, and high prey abundance (M. pennsylvanicus) suggests these areas may provide foraging opportunities for snakes. To minimize effects of pipeline construction in forested areas on salamander populations, routes should be sited along existing linear disturbance where possible to limit additional fragmentation. Where no disturbance is present, young forest stands (small basal area, low canopy cover) should be prioritized over mature forest stands (high basal area, high canopy cover). 


\section{Literature Cited}

Akaike, H. 1973. Information theory as an extension of the maximum likelihood principle. Pages 267-281 in. Second International Symposium on Informantion Theory, Akademiai Kiado, Budapest.

Allouche, E. N., S. T. Araratnam, and J. S. Lueke. 2000. Horizontal Directional Drilling: Profile of an Emerging Industry. Journal of Construction Engineering and Management 126:68-76.

Andrews, K., W. Gibbons, and D. Jochimsen. 2008. Ecological effects of roads on amphibians and reptiles: a literature review. Herpetological Conservation. Volume 3. <http://transwildalliance.org/resources/2009101416234.pdf>.

Arnold, T. W. 2010. Uninformative Parameters and Model Selection Using Akaike's Information Criterion. Journal of Wildlife Management 74:1175-1178.

Bailey, L. L., T. R. Simons, and K. H. Pollock. 2004. Estimating site occupancy and species detection probability parameters for terrestrial salamanders. Ecological Applications 14:692-702.

Brand, A. B., A. N. M. Wiewel, and E. H. C. Grant. 2014. Potential reduction in terrestrial salamander ranges associated with Marcellus shale development. Biological Conservation 180:233-240. Elsevier Ltd. <http://dx.doi.org/10.1016/j.biocon.2014.10.008>.

Brannon, P., E. C. Allan, and M. C. Silinski. 2014. Terrestrial Salamander Abundances Along and Within an Electric Power Line Right-of-Way. Journal of the North Carolina Academy of Science 132:40-45.

Burnham, K. P., D. R. Anderson, and K. P. Huyvaert. 2011. AIC model selection and multimodel inference in behavioral ecology: Some background, observations, and comparisons. Behavioral Ecology and Sociobiology 65:23-35.

Carfagno, G. L. F., and P. J. Weatherhead. 2006. Intraspecific and interspecific variation in use of forest-edge habitat by snakes. Canadian Journal of Zoology 84:1440-1452.

Carter, K. M., J. A. Harper, K. W. Schmid, and J. Kostelnik. 2011. Unconventional natural gas resources in Pennsylvania: The backstory of the modern Marcellus Shale play. Environmental Geosciences 18:217-257.

Chen, J., S. C. Saunders, T. R. Crow, R. J. Naiman, K. D. Brosofske, G. D. Mroz, B. L. Brookshire, and J. F. Franklin. 1999. Microclimate in forest ecosystem and landscape ecology: Variations in local climate can be used to monitor and compare the effects of different management regimes. BioScience 49:288-297.

Clark, R. W. 2002. Diet of the Timber Rattlesnake ,. Society for the Stusy of Amphibians and Reptiles 36:494-499.

DeGraaf, R. M., and M. Yamasaki. 2002. Erratum: Effects of edge contrasts on redback salamander distribution in even-aged northern hardwoods. (Forest Science 48:2 (351-363)). Forest Science 48:625.

Demaynadier, P. G., and M. L. Hunter. 1998. Effects of silvicultural edges on the distribution 
and abundance of amphibians in maine. Conservation Biology 12:340-352.

Drohan, P. J., M. Brittingham, J. Bishop, and K. Yoder. 2012. Early trends in landcover change and forest fragmentation due to shale-gas development in Pennsylvania: A potential outcome for the northcentral appalachians. Environmental Management 49:1061-1075.

Fischer, J., and D. B. Lindenmayer. 2007. Landscape modification and habitat fragmentation: A synthesis. Global Ecology and Biogeography 16:265-280.

Gibbs, J. P. 1998. Distribution of woodland amphibians along a forest fragmentation gradient. Landscape Ecology 13:263-268.

Grant, B. W., A. D. Tucker, J. E. Lovich, A. M. Mills, P. M. Dixon, and J. W. Gibbons. 1992. Wildlife 2001. Elsevier Science Publishing, Inc., London, England.

Hesed, K. M. 2012. Uncovering Salamander Ecology : A Review of Coverboard Design. Journal of Herpetology 46:442-450.

Kiviat, E. 2013. Risks to biodiversity from hydraulic fracturing for natural gas in the Marcellus and Utica shales. Annals of the New York Academy of Sciences 1286:1-14.

Knapp, S. M., C. A. Haas, D. N. Harpole, and R. L. Kirkpatrick. 2003. Initial effects of clearcutting and alternative silvicultural practices on terrestrial salamander abundance. Conservation Biology 17:752-762.

Langlois, L. A., P. J. Drohan, and M. C. Brittingham. 2017. Linear infrastructure drives habitat conversion and forest fragmentation associated with Marcellus shale gas development in a forested landscape. Journal of Environmental Management 197:167-176. Elsevier Ltd. <http://dx.doi.org/10.1016/j.jenvman.2017.03.045>.

Macneil, J. E., and R. N. Williams. 2014. Effects of timber harvests and silvicultural edges on terrestrial salamanders. PLoS ONE 9:1-27.

Manson, R. H., R. S. Ostfeld, and C. D. Canham. 1999. Responses of a small mammal community to heterogeneity along forest-old-field edges. Landscape Ecology 14:355-367.

Margenau, E. L. 2020. Avian and salamander response to young forest management in West Virginia. West Virginia University.

Marsh, D. M. 2007. Edge Effects of Gated and Ungated Roads on Terrestrial Salamanders. Journal of Wildlife Management 71:389-394.

Marsh, D. M., and N. G. Beckman. 2004. Effects of forest roads on the abundance and activity of terrestrial salamanders. Ecological Applications 14:1882-1891.

Marsh, D. M., G. S. Milam, N. P. Gorham, and N. G. Beckman. 2005. Forest roads as partial barriers to terrestrial salamander movement. Conservation Biology 19:2004-2008.

Marsh, D. M., R. B. Page, T. J. Hanlon, R. Corritone, E. C. Little, D. E. Seifert, and P. R. Cabe. 2008. Effects of roads on patterns of genetic differentiation in red-backed salamanders, Plethodon cinereus. Conservation Genetics 9:603-613.

Moore, J. D. 2005. Use of native dominant wood as a new coverboard type for monitoring 
eastern red-backed salamanders. Herpetological Review 36:268-271.

Moran, M. D., A. B. Cox, R. L. Wells, C. C. Benichou, and M. R. McClung. 2015. Habitat Loss and Modification Due to Gas Development in the Fayetteville Shale. Environmental Management 55:1276-1284. Springer US. <http://dx.doi.org/10.1007/s00267-014-0440-6>.

Moseley, K. R., W. M. Ford, and J. W. Edwards. 2009. Local and landscape scale factors influencing edge effects on woodland salamanders. Environmental Monitoring and Assessment 151:425-435.

Murcia, C. 1995a. Edge effects in fragmented forests: implications for conservation. Trends in Ecology \& Evolution 10:58-62.

Murcia, C. 1995b. Edge effects in fragmented forests: implications for conservation. Trends in Ecology \& Evolution 10:58-62.

O’Donnell, K. M., F. R. Thompson, and R. D. Semlitsch. 2014. Predicting variation in microhabitat utilization of terrestrial salamanders. Herpetologica 70:259-265.

PADEP. 2018. Issued Gas Well Permits. Pennsylvania Department of Environmental Protection. $<\mathrm{http} / / /$ www.depreportingservices.state.pa.us/ReportServer/Pages/ReportViewer.aspx?/Oil_ Gas/Permits_Issued_Detail>.

Patrick, D. A., and J. P. Gibbs. 2009. Snake Occurrences in Grassland Associated with Road versus Forest Edges. Journal of Herpetology 43:716-720.

Phillips, D. L., and D. J. Shure. 1990. Patch-size effects on early succession in Southern Appalachian forests. Ecology 71:204-212.

Reinert, H. K. 1993. Snakes: ecology and behavior. R. A. Seigel and J. T. Collins, editors. McGraw-Hill, New York.

Reinert, H. K., W. F. Munroe, C. E. Brennan, M. N. Rach, S. Pelesky, and L. M. Bushar. 2011. Response of timber rattlesnakes to commercial logging operations. Journal of Wildlife Management 75:19-29.

Semlitsch, R. D., T. J. Ryan, K. Hamed, M. Chatfield, B. Drehman, N. Pekarek, M. Spath, and A. Watland. 2007. Salamander abundance along road edges and within abandoned logging roads in Appalachian Forests. Conservation Biology 21:159-167.

Silva, M., L. A. Hartling, S. A. Field, and K. Teather. 2003. The effects of habitat fragmentation on amphibian species richness of Prince Edward Island. Canadian Journal of Zoology 81:563-573.

Slonecker, E., L. Milheim, and C. Roig-Silva. 2012. Landscape Consequences of Natural Gas Extraction in Bradford and Washington Counties, Pennsylvania, 2004-2010. US Geological Survey Open ... 2004-2010.

<http://scholar.google.com/scholar?hl=en\&btnG=Search\&q=intitle:Landscape+Consequenc es+of+Natural+Gas+Extraction+in+Bradford+and+Washington+Counties+,+Pennsylvania+ ,+2004+?+2010\#0>.

Stauffer, A. 2016. Timber Rattlesnake Conservation Strategy for Pennsylvania State Forest 
Lands.

Weatherhead, P. J., and M. B. Charland. 1985. Habitat Selection in an Ontario Population of the Snake. Jounral of Herpetology 19:12-19.

Wright, T. E., S. Kasel, M. Tausz, and L. T. Bennett. 2010. Edge microclimate of temperate woodlands as affected by adjoining land use. Agricultural and Forest Meteorology 150:1138-1146. Elsevier B.V. <http://dx.doi.org/10.1016/j.agrformet.2010.04.016>.

Yahner, R. H. 2004. Wildlife Response to More Than 50 Years of Vegetation Maintenance on a Pennsylvania, U.S., Right-of-Way. Journal of Arboriculture 30:123-126. 


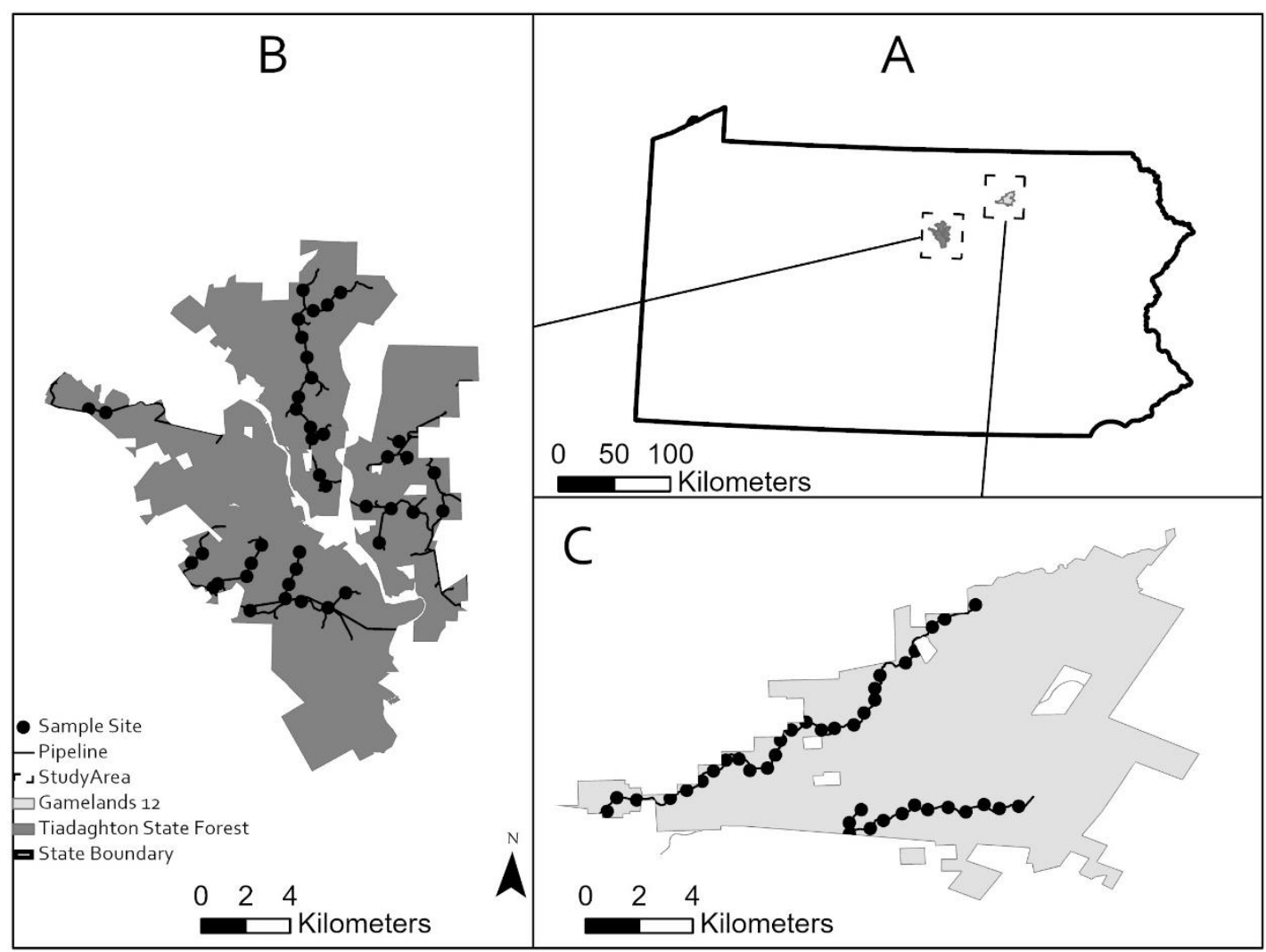

Figure 3.1: Location of main study sites in Pennsylvania (A). Site B is the Tiadaghton State Forest while C is PA state Game Lands 12. Study sites located on Pennsylvania Game Commission game lands 12.80 sample sites are evenly distributed between A and B. All pipelines in the Tiadaghton State Forest were constructed in 2013. There are 2 pipelines within the game lands site, the northern line completed in 2019 and the southern line completed in 2017. 


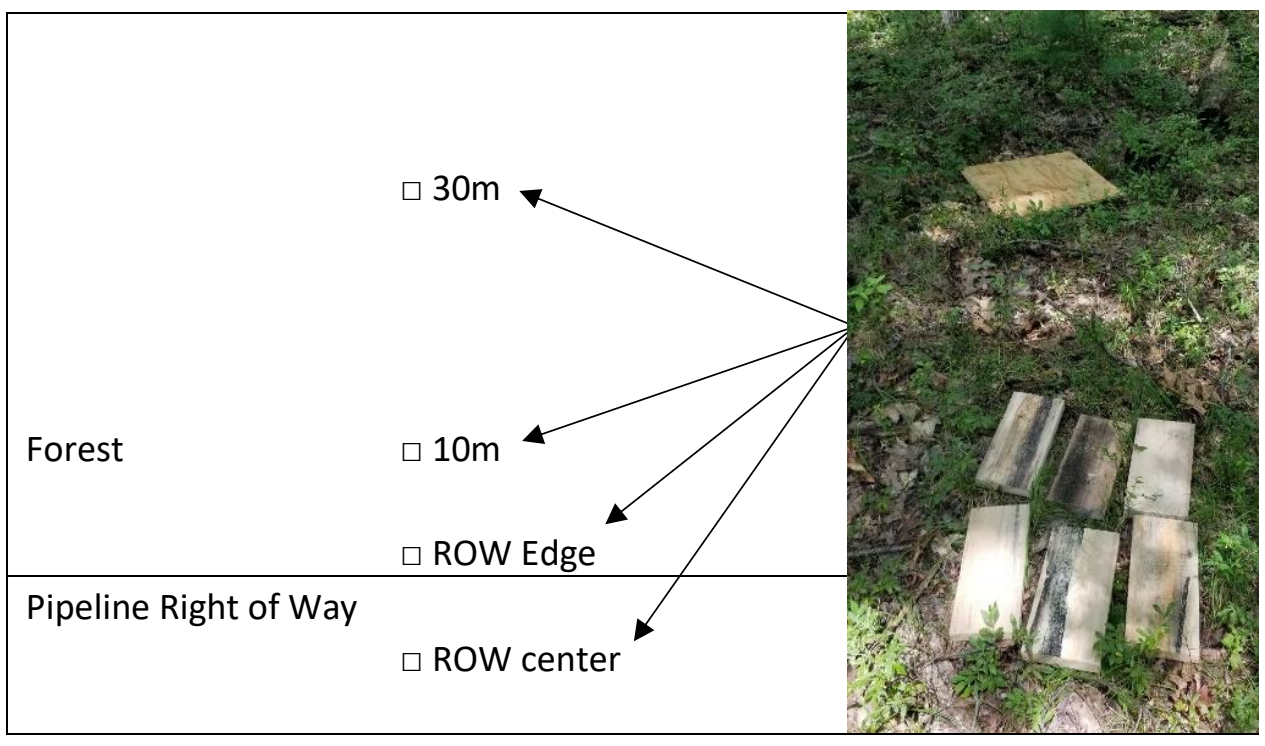

Figure 3.2 Cover board array placement in relation to the right of way. $60 \times 60 \times 1.27-\mathrm{cm}$ untreated plywood and 6 board arrays of $15^{\times} 30.5 \times 2.5-\mathrm{cm}$ untreated poplar were placed at the center of the right of way, the edge of the right of way, and $10 \mathrm{~m}$ and $30 \mathrm{~m}$ past the edge of the right of way. These cover boards sets were placed at 80 locations along pipelines with the Tiadaghton State Forest and game lands 12 study sites. 


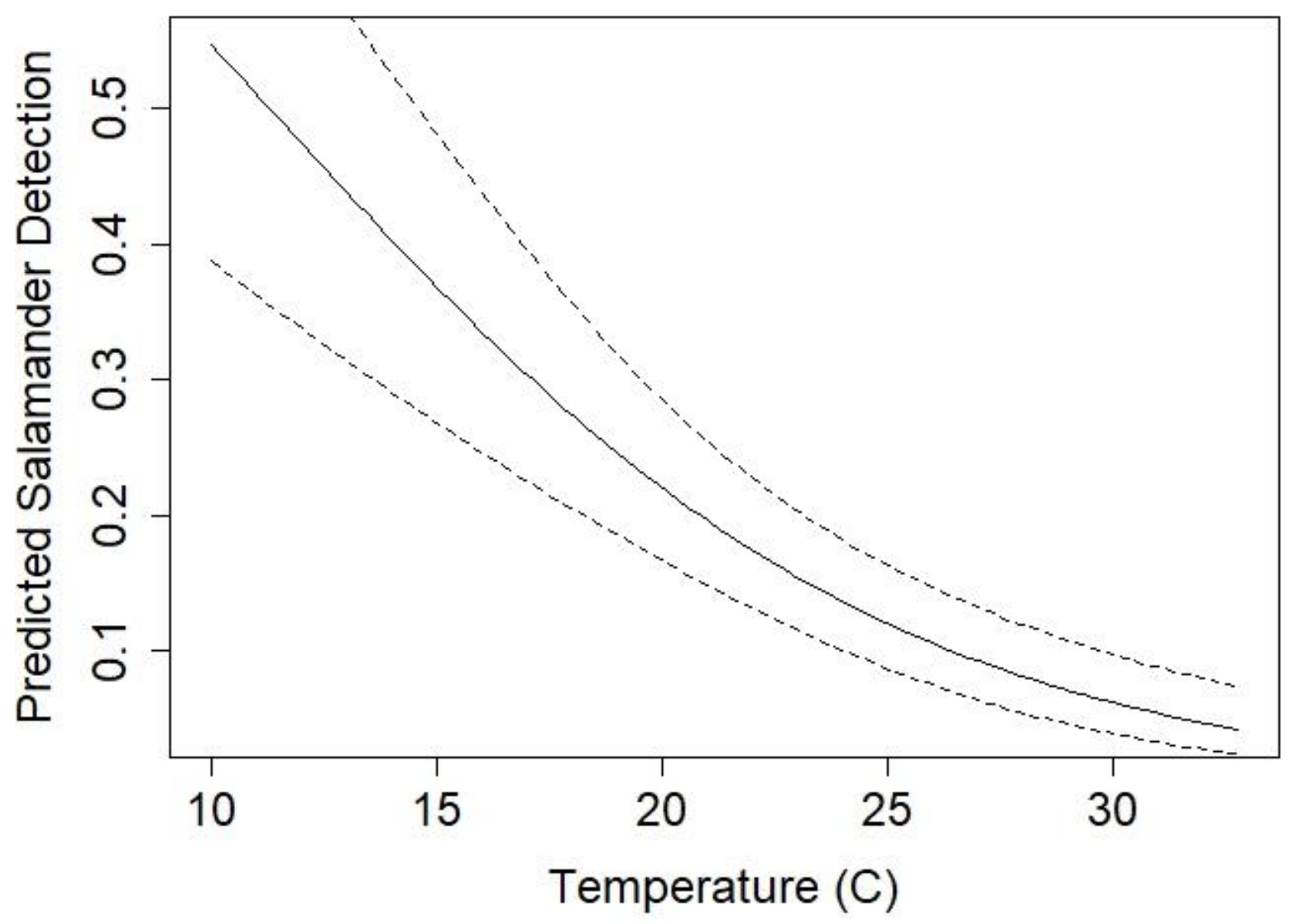

Figure 3.3: Predicted $P$. cinereus detection probability related with temperature. 320 cover board

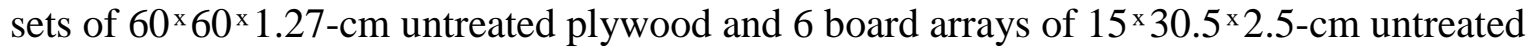
poplar were deployed in Northern Pennsylvania along natural gas pipelines. Temperature was the top supported model of all detection variables and carried through remaining analysis (temperature, search duration, precipitation, time of day, wind, date, and wind). Model support was ranked using Akaike's information criterion corrected for small sample size. The solid line represents the mean detection prediction and the dashed lines represent upper and lower $85 \%$ confidence intervals. 

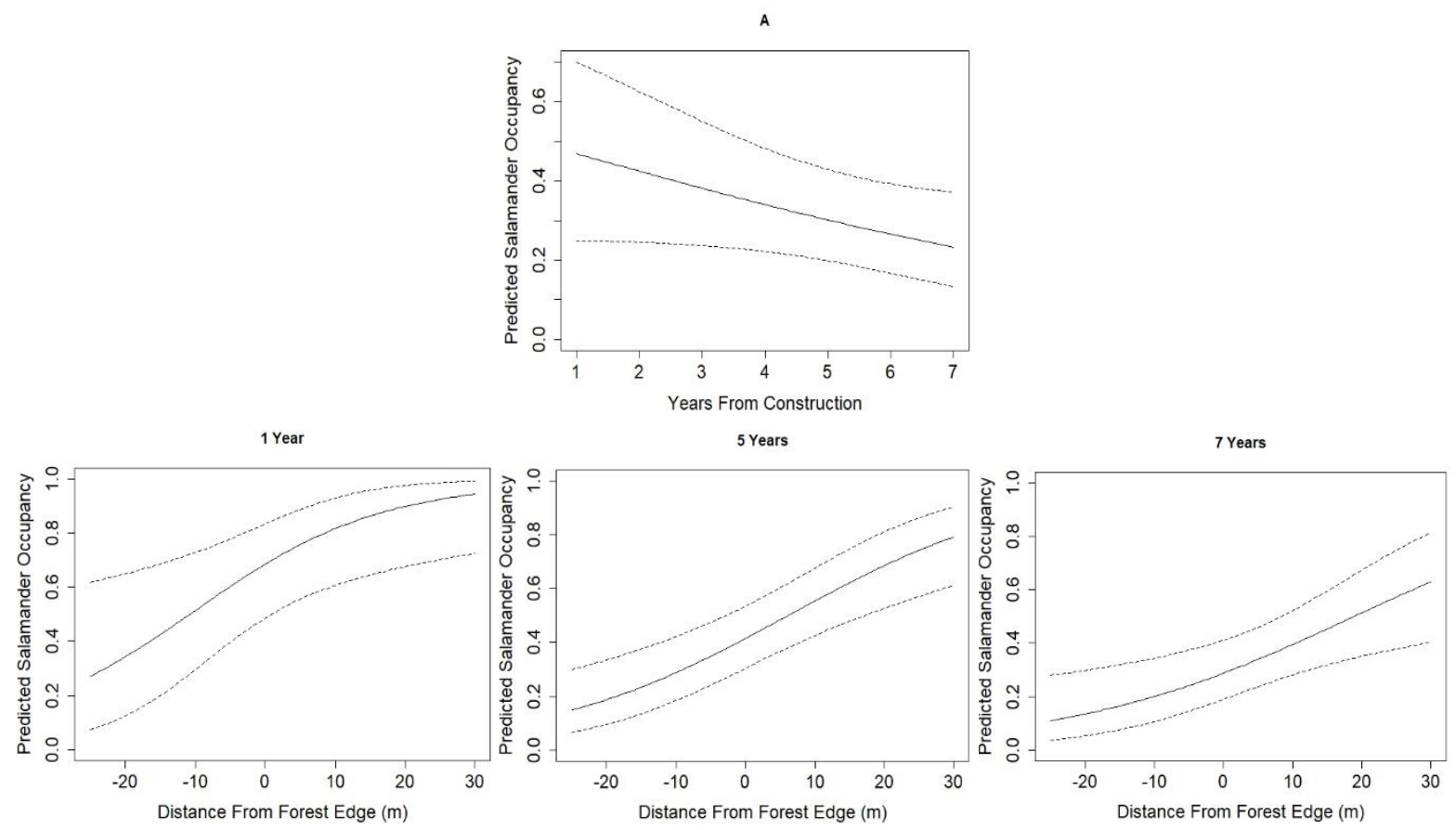

Figure 3.4: Predicted $P$. cinereus occupancy probability related with pipeline right of way (ROW) age and cover board distance from the forest edge. 320 cover board sets of $60^{\times} 60^{\times} 1.27$ $\mathrm{cm}$ untreated plywood and 6 board arrays of $15^{\times} 30.5 \times 2.5-\mathrm{cm}$ untreated poplar were set out in Northern Pennsylvania along natural gas pipelines. Temperature was the top supported model of all detection variables and carried through remaining analysis. Model support was ranked using Akaike's information criterion corrected for small sample size. The solid line represents the mean occupancy prediction and the dashed lines represent upper and lower $85 \%$ confidence intervals. 
A

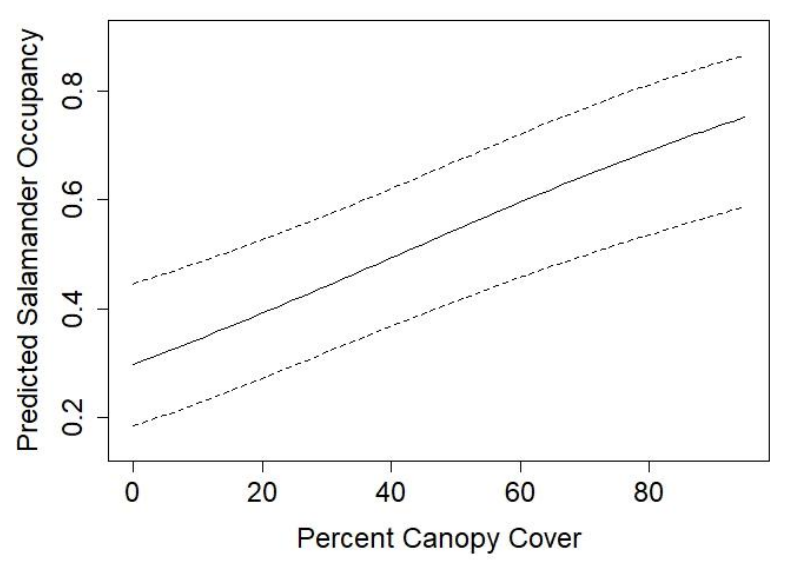

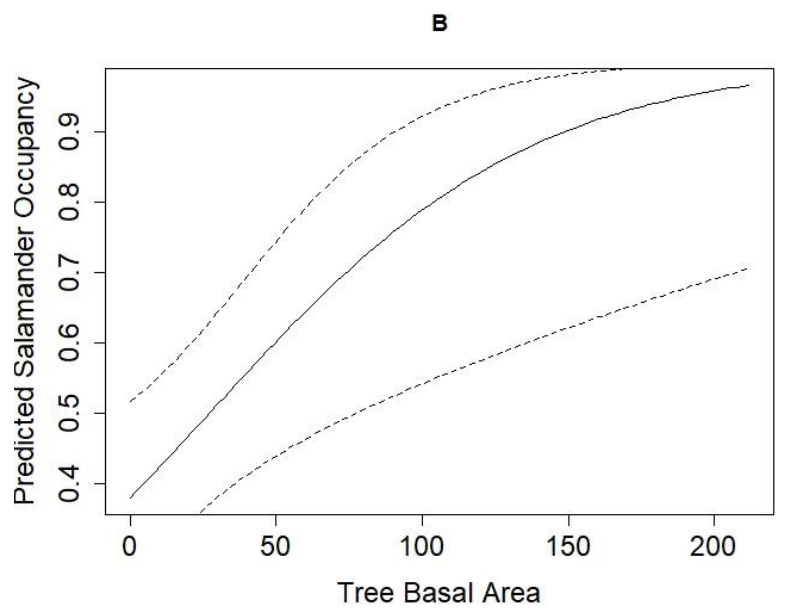

C

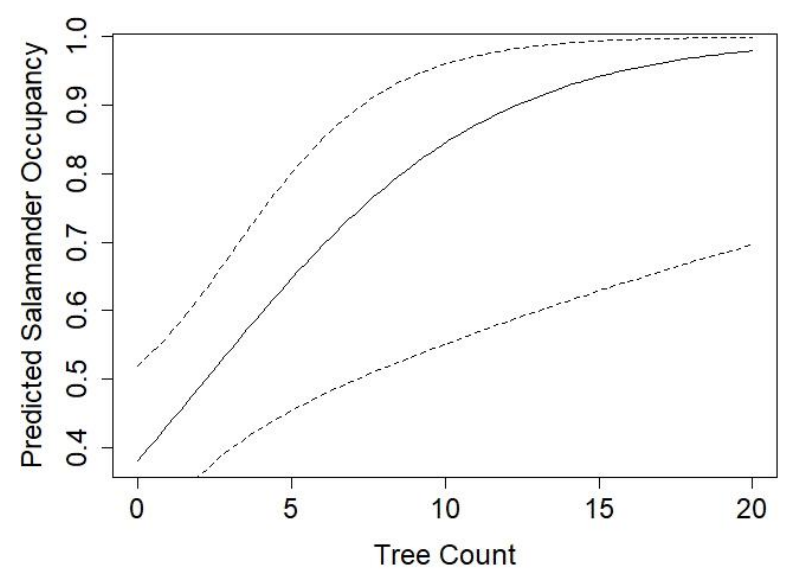

Figure 3.5: Predicted $P$. cinereus occupancy probability related with top supported forest structure covariates: canopy cover, basal area of trees larger than $15.24 \mathrm{~cm}$ dbh within $10 \mathrm{~m}$, and the count of trees larger than $15.24 \mathrm{~cm}$ dbh within $10 \mathrm{~m} .320$ cover board sets of $60 \times 60 \times 1.27-\mathrm{cm}$ untreated plywood and 6 board arrays of $15 \times 30.5 \times 2.5-\mathrm{cm}$ untreated poplar were set out in Northern Pennsylvania along natural gas pipelines. Temperature was the top supported model of all detection variables and carried through remaining analysis. Model support was ranked using Akaike's information criterion corrected for small sample size. The solid line represents the mean occupancy prediction and the dashed lines represent upper and lower $85 \%$ confidence intervals. 
Table 3.1: Covariates recorded to account for imperfect detection during cover board surveys. Detection covariates were chosen based on their impact to temperature or soil moisture, which influences terrestrial salamander surface activity. All covariates were measured at the beginning of cover board searches

\begin{tabular}{ll}
\hline Detection covariates & Description \\
\hline Date & Julian date of survey \\
Time Start & $\begin{array}{l}\text { start of survey in minute of the day } \\
\text { elapsed time of survey in minutes } \\
\text { Duration }\end{array}$ \\
$\begin{array}{l}\text { Temperature }(\mathrm{C}) \\
\text { temperature at time of survey } \\
\text { (quadratic) }\end{array}$ & $\begin{array}{l}\text { temperature quadratic } \\
\text { Wind speed in mph }\end{array}$ \\
Wind Speed & $\begin{array}{l}\text { categorical weather - Full sun, partly cloudy, } \\
\text { overcast, light precipitation, medium precipitation, high precipitation }\end{array}$ \\
\hline
\end{tabular}


Table 3.2: Surrounding forest measurements taken at all cover board sites surveyed for salamanders and snakes. Variables which indicate forest structure and age were chosen based on their relationship with soil moisture and ground temperature.

\begin{tabular}{|c|c|}
\hline Covariates & Description/ Justification \\
\hline ROW distance & Distance from ROW edge, closer sites should see more edge effects \\
\hline Canopy Height & Taller canopy is indicative of mature forest, lowers ground temperature \\
\hline Canopy Cover & Higher canopy cover should block sunlight and reduce surface temperatures \\
\hline Tree count & $\begin{array}{l}\text { number of trees with a diameter larger than } 15.24 \mathrm{~cm} \text { at breast height within } 10 \mathrm{~m} \text {, indicative of } \\
\text { mature forest }\end{array}$ \\
\hline Tree Basal Area & $\begin{array}{l}\text { Basal area of trees with a diameter larger than } 15.24 \mathrm{~cm} \text { at breast height within } 10 \mathrm{~m} \text {, indicative } \\
\text { of mature forest }\end{array}$ \\
\hline Stems $<2.54 \mathrm{~cm}$ & Number of stems with a diameter smaller than $2.54 \mathrm{~cm}$ within $8 \mathrm{~m}^{2}$ plot adjacent to cover boards \\
\hline Stems $2.55-7.62 \mathrm{~cm}$ & $\begin{array}{l}\text { Number of stems with a diameter between } 2.54 \text { and } 7.62 \mathrm{~cm} \text { within } 8 \mathrm{~m}^{2} \text { plot adjacent to cover } \\
\text { boards }\end{array}$ \\
\hline Stems $7.63-15.24 \mathrm{~cm}$ & $\begin{array}{l}\text { Number of stems with a diameter smaller than } 7.62 \text { and } 15.24 \mathrm{~cm} \text { within } 8 \mathrm{~m}^{2} \text { plot adjacent to } \\
\text { cover boards }\end{array}$ \\
\hline
\end{tabular}


Table 3.3: Catch per coverboard set of all salamander and snake species observed during surveys. Catch per unit effort (CPUE) is divided between study sites at game lands 12 (GL12) and Tiadaghton State Forest (TDSF) as well as distance from the pipeline right of way (ROW). Coverboards were placed in the center of the ROW, at the ROW edge, $10 \mathrm{~m}$ from the edge, and $30 \mathrm{~m}$ from the edge at 80 sites evenly distributed between both study sites.

\begin{tabular}{l|rr|rrrrr}
\hline \multicolumn{1}{c}{ Catch Per Unit Effort } \\
\hline Species & \multicolumn{1}{c}{ GL12 } & \multicolumn{1}{c}{ TDSF } & \multicolumn{1}{c}{ ROW } & Edge & $10 \mathrm{~m}$ & $30 \mathrm{~m}$ & \multicolumn{1}{c}{ Total } \\
\hline Plethodon cinereus & 0.375 & 0.143 & 0.05 & 0.081 & 0.146 & 0.240 & 0.518 \\
Nopthalmus viridescens & 0.025 & 0.012 & 0.025 & 0.006 & 0 & 0.006 & 0.037 \\
Plethodon glutinosus & 0.003 & 0.012 & 0 & 0 & 0.003 & 0.012 & 0.006 \\
Thamnophis sirtalis & 0.009 & 0.028 & 0.025 & 0.006 & 0 & 0.015 \\
Diadophis punctatus & 0.006 & 0.018 & 0.009 & 0.009 & 0.003 & 0.003 & 0 \\
Storeria dekavi & 0.006 & 0.003 & 0.006 & 0.003 & 0 & 0.025 \\
Lampropeltis trangulum & 0 & 0.003 & 0 & 0.003 & 0 & 0.009 \\
Storeria occipitomaculata & 0.006 & 0.003 & 0.009 & 0 & 0 & 0 \\
Opheodrys vernalis & 0.003 & 0 & 0.003 & 0 & 0 & 0.003 \\
\end{tabular}


Table 3.4: P. cinereus modeling results for detection and beta coefficients of temperature from the top model. Models within $2 \Delta \mathrm{AIC}$ of the top model were assumed to have strong support, and models within $5 \Delta \mathrm{AIC}$ to have moderate support.

\begin{tabular}{|c|c|c|c|c|c|c|c|}
\hline Detection & & & & Age \& Distance & & & \\
\hline Model covariates & $\mathrm{AICc}$ & $\Delta \mathrm{AIC}$ & $\omega$ & Model covariates & $\mathrm{AICc}$ & $\Delta \mathrm{AIC}$ & $\omega$ \\
\hline Temperature & 853.29 & 0 & 0.64 & Age : Distance & 818.8 & 0 & 0.5 \\
\hline Temperature (quadratic) & 854.46 & 1.18 & 0.36 & Age + Distance & 818.96 & 0.06 & 0.49 \\
\hline Temperature + Wind + Precipitation & 876.64 & 23.35 & 0 & Distance & 827.87 & 8.38 & 0.01 \\
\hline Search Duration & 888.38 & 35.09 & 0 & Age & 836.61 & 17.55 & 0 \\
\hline Precipitation & 892.49 & 39.2 & 0 & Null & 853.29 & 33.45 & 0 \\
\hline Null & 895.64 & 42.35 & 0 & & & & \\
\hline Time of Day & 897.21 & 43.92 & 0 & Forest Structure & & & \\
\hline Wind & 914.45 & 61.16 & 0 & Canopy Cover & 835.65 & 0 & 0.59 \\
\hline Julian Date & 1037.09 & 183.8 & 0 & stem $2.55-7.62 \mathrm{~cm}$ & 837.99 & 2.34 & 0.18 \\
\hline Julian Date + Time of Day + Search Duration & 1041.21 & 187.92 & 0 & Tree Basal Area & 839.12 & 3.47 & 0.1 \\
\hline \multirow[t]{5}{*}{ Full Model } & 1087.81 & 234.52 & 0 & Tree Count & 839.29 & 3.64 & 0.1 \\
\hline & & & & Stem $7.63-15.24 \mathrm{~cm}$ & 841.53 & 5.88 & 0.03 \\
\hline & & & & Canopy Height & 851.95 & 16.3 & 0 \\
\hline & & & & Stem $<2.54 \mathrm{~cm}$ & 852.92 & 17.27 & 0 \\
\hline & & & & Null & 853.29 & 17.64 & 0 \\
\hline
\end{tabular}


Table 3.5: Plethodon cinereus occupancy modeling results of age and distance from the ROW. Models within $2 \Delta$ AIC of the top model were assumed to have strong support, and models within $5 \triangle \mathrm{AIC}$ to have moderate support. Coefficients in bold had confidence intervals which did not overlap zero.

\begin{tabular}{lrrrr}
\hline Model Covariate & $\beta$ from top model & \multicolumn{1}{c}{ SE } & 85\% CI Lower & 85\% CI Upper \\
\hline Intercept & 0.05226938 & 0.583066 & -1.09052 & 1.195058 \\
Age & -0.1788102 & 0.100778 & -0.37633 & 0.01871 \\
Distance & $\mathbf{0 . 0 7 5 4 9 0 5 7}$ & $\mathbf{0 . 0 3 4 5 7 9}$ & $\mathbf{0 . 0 0 7 7 1 7}$ & $\mathbf{0 . 1 4 3 2 6 5}$ \\
Age:Distance & -0.004179809 & 0.005966 & -0.01587 & 0.007513 \\
\hline
\end{tabular}


Chapter 4:

Variation in Pollinator Presence Along Natural Gas Pipeline Right of Ways in Northern Appalachia 
Formatted for submission to the Journal Biodiversity and Conservation

\title{
Variation in pollinator presence along natural gas pipeline right of ways in northern
}

\section{Appalachia}

\begin{abstract}
Recent global decline of pollinators has been attributed to many factors, including loss of habitat, pollution, and agricultural use of herbicides and pesticides. The Appalachian region of the United States has undergone forest maturation on a large scale, with few areas of grassland and young forest habitat present on the landscape. Powerline corridors have previously been found to positively impact pollinator populations, and I predicted that natural gas pipeline right of ways (ROW) could serve a similar role. I examined butterfly and bee density and species richness along natural gas pipelines that varied in age, width, vegetation structure and composition, and seed mix used. The best predictor of butterfly richness, and bee and butterfly density was the percentage of flowering plants. These results suggest that ROW, similar to powerline corridors, can provide benefits to local pollinators if they are reclaimed with diverse mixes of native plants that prioritize flower density over a grass monoculture.
\end{abstract}

Keywords: bee, butterfly, Marcellus, natural gas, pollinator, right of way, ROW 


\subsection{Introduction}

Pollinator populations have shown marked declines globally over the previous decades (Kluser and Peduzzi 2007, Rhodes 2018). Potential causes are varied, including habitat loss, use of herbicides and pesticides in agriculture, increasing homogeneity on large-scale farms, disease, and invasive species (Cane and Tepedino 2001). Although ecological services of pollinators are largely focused on the non-native honey bee (Apis Spp.) and agricultural pollination, there are many types of native pollinator insects that also provide this ecological service, among others. In the Appalachian region of the United States, early successional habitat that provides forage habitat for pollinators has been declining due to changes in agricultural practices, forest maturation, and the abandonment of small-scale farms (Stauffer et al. 2018).

The Appalachian region has also seen extensive development of natural gas resources within the last 15 years (Carter et al. 2011). Horizontal drilling technology enabled more efficient extraction of gas from the Marcellus Shale, a deeper geologic layer than had been previously developed (Carter et al. 2011, Zinkhan Jr. 2016). Compared with conventional vertical wells, multiple unconventional horizontal wells can be co-located on a single well pad (Zinkhan Jr. 2016). Along with an increase in production when utilizing hydraulic fracturing, an unconventional well pad can produce larger volumes of natural gas than a vertical well (Carter et al. 2011). Large gas volumes necessitate connecting wells and storage and production facilities using pipelines.

Natural gas pipeline right of ways (ROW) must be managed to preclude the growth of large tree roots that could negatively impact pipeline integrity. A larger body of research exists for powerline corridors, which is a similar analogue to a pipeline ROW. Vegetation is commonly controlled using mechanical or chemical methods to eliminate woody growth (Wagner et al. 
2014). When these ROWs are routed through forested areas, they act as narrow corridors of early successional habitat. While these linear ROWs can increase forest fragmentation, they can also create habitat for pollinators and other insect species (Sheridan et al. 1997, Langlois et al. 2017, Wagner et al. 2019). Powerline ROWs have been found to support populations of rare and threatened pollinator species in an otherwise forested landscape (Sheridan et al. 1997). Similarities between powerline ROWs and natural gas pipeline ROWs suggest that reclaimed ROWs may benefit pollinators in predominately forested habitats.

This study examined pollinator diversity and density along natural gas pipeline ROWs in Northern Pennsylvania. Pipeline ROWs varied in width, age, and seed mix used during reclamation. I predicted that foraging habitat of butterflies is most influenced by flower diversity and vegetation structure, and that differences in seed mixes planted during ROW reclamation would influence pollinator presence. I also predicted that butterfly species richness would increase as the proportion of flowering plants increased. Older ROWs should have higher butterfly species richness than younger ROWs due to taller, denser vegetation that provides cover and forage habitat. Variation in pollinator presence among sites informs best management practices for creating forage habitat for pollinators on pipeline ROWs.

\subsection{Methods}

\subsubsection{Study Site}

The study area included two land parcels managed by the State of Pennsylvania: the Tiadaghton State Forest and Game lands 12 (Figure 4.1). These state-managed land parcels are within $100 \mathrm{~km}$ of the city of Williamsport and heavily forested. Average annual temperatures 
range from $1-13^{\circ} \mathrm{C}$, and annual precipitation is $305 \mathrm{~cm}$ including snowfall. The dominant forest type is northern hardwood, with American beech (Fagus grandifolia), red maple (Acer rubrum), black cherry (Prunus serotina), white oak (Quercus alba), chestnut oak (Quercus montana), white pine (Pinus strobus), and eastern hemlock (Tsuga canadensis) being common. Study sites were chosen based on the quantity of gathering pipelines present and forest cover. Pipelines were hand digitized using publicly available National Agriculture Imagery Program (NAIP) Imagery from 2007 to 2016 and well permit locations from the Pennsylvania Department of Environmental Protection (PADEP 2018). The width, age, and reclamation plan for pipelines varied within and among sites. Eighty sites were located randomly along pipelines within the study areas (40 each on the Game lands and State Forest, respectively) and at least 500 meters apart.

The Tiadaghton State Forest is administered by the Pennsylvania Department of Conservation and Natural Resources (DCNR) and encompasses 59,300 hectares (Figure 4.1). This forest is located primarily in Lycoming County with some parcels extending into surrounding counties. Terrain includes steep mountains with cold mountain streams between them. Much of the ground cover is forest, and regular timber harvest does occur. The ridge-tops within the forest were primarily developed in 2012 and 2013 for natural gas extraction. Approximately $76 \mathrm{~km}$ of pipeline are present on the state forest to support 42 well pads and 254 wells as of 2018.

Game lands 12 (GL12) is approximately 10,350 hectares and administered by the Pennsylvania State Game Commission (Figure 3.1). It is located Northwest of the Tiadaghton State Forest, and is a more contiguous patch of land. Natural Gas development did not start until 2016 within the game lands, with the most recent pipeline completed in 2019. The southern trunk 
line is approximately $11 \mathrm{~km}$ long and was completed in 2016. The Northern pipeline is approximately $18 \mathrm{~km}$ long and was completed in 2019. This pipeline was reclaimed with 16 different seed mixes, all of which used a diverse assemblage of native plants.

\subsubsection{Sampling Protocol}

Eighty survey sites were randomly located along ROWs within the study areas, divided equally between the state forest and game lands. A modified Pollard walk was used to survey for butterflies and other pollinators at each study site along a 100m section of ROW (Pollard and Yates 1993). Transects were in the center of each ROW with a width of $5 \mathrm{~m}$ on each side. Surveys were conducted at a consistent walking pace, and all observed butterflies and bees photographed in a passive manner without netting or handling. If species were observed but are unable to be photographed, they were identified to the lowest level possible. Four total surveys were conducted between May and August during 2019 and 2020 to capture heterogeneity over time. All 80 sites were surveyed over four 2-week periods during each year, with each site at least 10 days apart. Surveys were conducted between the hours of 09:00 and 16:00 while weather was fair and vegetation was dry. Butterfly species richness was calculated for each site, along with the density of butterflies and bees observed (count per transect area).

\subsubsection{Pollinator Identification}

Butterflies were identified to the lowest taxonomic level possible given based on photographs. Butterflies of Pennsylvania (Monroe and Wright 2017)was the primary source for identifying to the species level. Some species exhibit high levels of visual similarity, (e.g.,. family Hesperiidae) and are difficult to identify without the use of a microscope. Visually similar species were counted as a single species because of these difficulties (see Appendix $\mathrm{H}$ for species groupings). Similar methods were used when photographs were of poor quality or did not 
show distinguishing identification characteristics. Bee species, many of which exhibit intraspecific visual heterogeneity, were not identified due to difficulties using photographs alone.

\subsubsection{Survey variables}

Vegetation and abiotic characteristics of the ROW were measured at each site. Vegetation was measured during each survey within 3 randomly placed $1-\mathrm{m}^{2}$ plots. Maximum vegetation height, the percentage of ground covered by vegetation, and the percentage of flowering plants were measured. Measurements from each plot were averaged for each survey, and the results of all surveys averaged for a single number for each site. ROW width and total opening width (including a road if present) were measured using a Bushnell laser rangefinder. ROW age obtained from pipeline environmental plans from the Pennsylvania Game Commission and Department of Conservation and Natural Resources, and verified using National Agriculture Imagery Program data.

\subsubsection{Data Analysis}

Butterfly density, butterfly species richness, and bee density were modeled separately using a general linear model assuming a Poisson or negative binomial distribution. A Poisson distribution was used for modeling butterfly species richness, and butterfly and bee density were modeled using a negative binomial distribution due to overdispersion. All analyses were performed using the program R (ver. 4.0.2) and the unmarked, AICmodAVG, and MASS packages. Biotic and abiotic covariates were measured at each site, and the relative importance of each tested within a model set. Models were created a priori and ranked using Akaike's Information Criterion for small sample sizes (AICc) (Akaike 1973). Models within $2 \Delta$ AIC of the top model are assumed to have considerable support, and models within $7 \Delta \mathrm{AIC}$ of the top model to have moderate support (Burnham et al. 2011). Models included in analysis were all 
covariates alone, an additive vegetation model with vegetation height, ground cover, and flower percentage, and a full model. Modeling occupancy would have provided better resolution of sitelevel changes over time, but it cannot be assumed that there is a closed population and that every species or individual is able to be detected during each survey. The hatch dates of butterfly species vary, and thus cannot be assumed that they are always present to be detected.

\subsection{Results}

\subsubsection{Summary statistics}

Twenty-five different species of butterfly were observed on ROWs during both field seasons. On average, butterfly richness per site was lower in 2020 than 2019 (3.36 and 4.48, respectively). Butterflies were observed at all sites, and bees observed at 74 of 80 . The highest butterfly species richness for a single site was 11 and the lowest 1 with a mean 2.42 , while the highest density during a survey was 18 with the lowest 0 and mean 3.38 . The highest bee density recorded from a survey was 53 with the lowest 0 and mean 5.39.

Right of Way vegetation height measurements ranged from 20.67 to $117.68 \mathrm{~cm}$ (avg $62.2 \mathrm{~cm}$ ). Average vegetation ground cover ranged from 25 to $97.08 \%$ (avg 81.15\%), and average flower percentage ranged from 0 to $36.67 \%$ (avg. 11.78\%). Flower percentage was the only measurement that decreased over time, as some areas did not have species that flowered throughout the field season.

\subsubsection{Modeling results}

Flower percentage was in all the top models when modeling butterfly species richness (Table 4.2). Richness was predicted to increase $(\beta=0.028, \mathrm{SE}=0.007,95 \% \mathrm{CI}(0.014,0.042))$ 
as flower percentage increased (Figure 4.2). Other models with support were the vegetation model and full model, although flower percentage was the only covariate in the top models which did not overlap zero within $95 \%$ confidence intervals.

The top model for butterfly density included flower percentage alone (Table 4.2). Predicted density increased $(\beta=0.04663244, \mathrm{SE}=0.006418,95 \% \mathrm{CI}(0.03405318,0.059212))$ as flower percentage increased (Figure 4.2). The vegetation and full models had some support (within $3 \Delta \mathrm{AIC}$ ), but all coefficients for variables apart from flower percentage overlapped zero within confidence intervals.

Bee density modeling followed similar trends to butterfly richness and density. Flower percentage was the top model, with the vegetation and full models having some support (Table 4.2). Density was predicted to increase $(\beta=0.106423, \mathrm{SE}=0.009901,95 \% \mathrm{CI}(0.08701704$, 0.125829)) as flower percentage increased (Figure 4.2). Flower percent was the only covariate within models with support whose estimated beta coefficient did not overlap zero within confidence intervals.

\subsection{Discussion}

The most important factor that predicted pollinator richness and density in every case was the percentage of actively flowering vegetation. This is a logical outcome and multiple studies have found similar results (Yahner 2004, Russell et al. 2018, Wagner et al. 2019, Russo et al. 2021). Food availability of nectar provides incentive for pollinators to forage in an area. For some species such as the monarch butterfly (Danaus plexippus) that require specific host plants, there is no alternative location in an otherwise forested setting for those host plants to exist 
besides areas of timber harvest or ROWs (Thogmartin et al. 2017). ROWs have been found to increase butterfly diversity and abundance in forested landscapes regardless of surrounding landcover type, likely due to specialist needs of some species (Berg et al. 2016).

Contrary to my predictions, neither ROW age nor width were supported predictors of density during modeling, although it is expected that pollinator numbers would increase as width increases. Since surveys on transects did not record all pollinators seen on the ROW, but only those within the $10 \mathrm{~m}$ width of the transect. Consequently, the total number of pollinators on a ROW is based on the total number of flowers present, regardless of other factors. Pollinator species richness and abundance have been found to be positively related with flower abundance (Russell et al. 2005, Eldegard et al. 2017b, Roberts et al. 2017). Poor support for age is most likely a result of large variation of flower percent along ROWs. Many older ROWs were nearly grass monocultures, which failed to produce food resources of nectar that would attract pollinators (Figure 4.3). Vegetation structure was on average taller and denser on older ROWs, and bee abundance has been linked to vegetation height (Roberts et al. 2017). The type of vegetation management was not examined in this study, but more frequent management has been found to promote diversity over non-managed fields (Eldegard et al. 2017b).

A factor that was not investigated in this study was change in flower cover over time. Anecdotally, there were sites where flower percentage changed drastically between visits. At sites where clover was the dominant species, flowers were only present during one or two surveys per year, but no flowers were present during the final survey. Sites that are planted to produce flowers throughout the growing season have been found to increase pollinator numbers (Eldegard et al. 2017b, Wagner et al. 2019). 
The results of this study show that the percentage of flowering plants on a ROW is the most influential factor in predicting pollinator density. The seed mixes planted on the youngest ROW (north-western most pipeline on the Game Lands 12 site) featured a diverse mix of annual and perennial forbs and grasses (Appendix G). The majority of these mixes were comprised of species that flowered in the mid or late season, which may be why pollinator observations were higher during those time periods. Sample sizes of sites were too small for comparison of effectiveness of each seed mix, and vegetation composition of each site will likely change over time as the perennial species become more established and mature. Additional study of these seed mixes over time and a more thorough examination of diversity is recommended. Overall, seed mixes should be chosen to provide as many flowers as possible for the longest duration of time. Choosing plant species that have asynchronous flowering cycles will extend the time that pollen and nectar food resources are available to pollinators. When there is the option, native plants should be prioritized over ornamentals and non-natives, as linear infrastructure has been found to increase invasive plant expansion (Barlow et al. 2017).

The only negative associated with a diverse and robust seed mix planting during reclamation is cost. It is easier for reclamation to only use one type of grass seed (the most commonly encountered monoculture on sites in this study) than to deal with 17 different mixes and worry about potential germination and soil erosion issues. Specialty native seeds and producing mixes are also much more expensive. In an ecological sense, there is no downside to creating a field analogue with a diverse mix of native flowering plants on a pipeline ROW. A ROW that is a grass monoculture provides no benefit to most types of wildlife or pollinators (Wagner et al. 2019). In forested areas that are already being negatively impacted by pipeline 
infrastructure (fragmentation and edge effects), reclaiming ROWs with high quality seed mixes provides a benefit for pollinators at no additional ecological cost. 


\section{Literature cited}

Akaike, H. 1973. Information theory as an extension of the maximum likelihood principle. Pages 267-281 in. Second International Symposium on Informantion Theory, Akademiai Kiado, Budapest.

Barlow, K. M., D. A. Mortensen, P. J. Drohan, and K. M. Averill. 2017. Unconventional gas development facilitates plant invasions. Journal of Environmental Management 202:208216. Elsevier Ltd. <http://dx.doi.org/10.1016/j.jenvman.2017.07.005>.

Berg, Å., K. O. Bergman, J. Wissman, M. Żmihorski, and E. Öckinger. 2016. Power-line corridors as source habitat for butterflies in forest landscapes. Biological Conservation 201:320-326.

Burnham, K. P., D. R. Anderson, and K. P. Huyvaert. 2011. AIC model selection and multimodel inference in behavioral ecology: Some background, observations, and comparisons. Behavioral Ecology and Sociobiology 65:23-35.

Cane, J. H., and V. J. Tepedino. 2001. Causes and extent of declines among native North American invertebrate pollinators: Detection, evidence, and consequences. Ecology and Society 5.

Carter, K. M., J. A. Harper, K. W. Schmid, and J. Kostelnik. 2011. Unconventional natural gas resources in Pennsylvania: The backstory of the modern Marcellus Shale play. Environmental Geosciences 18:217-257.

Eldegard, K., D. L. Eyitayo, M. H. Lie, and S. R. Moe. 2017. Can powerline clearings be managed to promote insect-pollinated plants and species associated with semi-natural grasslands? Landscape and Urban Planning 167:419-428. Elsevier. <http://dx.doi.org/10.1016/j.landurbplan.2017.07.017>.

Kluser, S., and P. Peduzzi. 2007. Global Pollinator Decline : A Literature Review'.

Langlois, L. A., P. J. Drohan, and M. C. Brittingham. 2017. Linear infrastructure drives habitat conversion and forest fragmentation associated with Marcellus shale gas development in a forested landscape. Journal of Environmental Management 197:167-176. Elsevier Ltd. <http://dx.doi.org/10.1016/j.jenvman.2017.03.045>.

Monroe, J. L., and D. M. Wright. 2017. Butterflies of Pennsylvania: a field guide. University of Pittsburgh Press, Pittsburgh.

PADEP. 2018. Issued Gas Well Permits. Pennsylvania Department of Environmental Protection. <http://www.depreportingservices.state.pa.us/ReportServer/Pages/ReportViewer.aspx?/Oil_ Gas/Permits_Issued_Detail>.

Pollard, E., and T. Yates. 1993. Monitoring Butterflies for Ecology and Conservation. Chapman \& Hall, London, UK.

Rhodes, C. J. 2018. Pollinator decline - An ecological calamity in the making? Science Progress 101:121-160.

Roberts, H. P., D. I. King, and J. Milam. 2017. Factors affecting bee communities in forest 
openings and adjacent mature forest. Forest Ecology and Management 394:111-122.

Elsevier B.V. <http://dx.doi.org/10.1016/j.foreco.2017.03.027>.

Russell, K. N., H. Ikerd, and S. Droege. 2005. The potential conservation value of unmowed powerline strips for native bees. Biological Conservation 124:133-148.

Russell, K. N., G. J. Russell, K. L. Kaplan, S. Mian, and S. Kornbluth. 2018. Increasing the conservation value of powerline corridors for wild bees through vegetation management: an experimental approach. Biodiversity and Conservation 27:2541-2565. Springer Netherlands. <https://doi.org/10.1007/s10531-018-1552-8>.

Russo, L., H. Stout, D. Roberts, B. D. Ross, and C. G. Mahan. 2021. Powerline right-of-way management and flower-visiting insects : How vegetation management can promote pollinator diversity. PLoS ONE 1-17. <http://dx.doi.org/10.1371/journal.pone.0245146>.

Sheridan, P. M., S. L. Orzell, and E. L. Bridges. 1997. Powerline easements as refugia for state rare seepage and pineland plant taxa. Sixth International Symposium on Environmental Concerns in Rights-of-Way Management. JR Williams, JW Goodrich-Mahoney, JR Wisniewski, and J. Wisniewski, editors. Elsevier Science, Oxford, England 451-460. <http://www.pitcherplant.org/Papers/powerlineeasements.htm>.

Stauffer, G. E., D. A. W. Miller, L. M. Williams, and J. Brown. 2018. Ruffed grouse population declines after introduction of West Nile virus. Journal of Wildlife Management 82:165-172.

Thogmartin, W. E., R. Wiederholt, K. Oberhauser, R. G. Drum, J. E. Diffendorfer, S. Altizer, O. R. Taylor, J. Pleasants, D. Semmens, B. Semmens, R. Erickson, K. Libby, and L. LopezHoffman. 2017. Monarch butterfly population decline in north america: Identifying the threatening processes. Royal Society Open Science 4.

Wagner, D. L., K. J. Metzler, and H. Frye. 2019. Importance of transmission line corridors for conservation of native bees and other wildlife. Biological Conservation 235:147-156. Elsevier. <https://doi.org/10.1016/j.biocon.2019.03.042>.

Wagner, D. L., K. J. Metzler, S. A. Leicht-Young, and G. Motzkin. 2014. Vegetation composition along a New England transmission line corridor and its implications for other trophic levels. Forest Ecology and Management 327:231-239. Elsevier B.V. <http://dx.doi.org/10.1016/j.foreco.2014.04.026>.

Yahner, R. H. 2004. Wildlife Response to More Than 50 Years of Vegetation Maintenance on a Pennsylvania, U.S., Right-of-Way. Journal of Arboriculture 30:123-126.

Zinkhan Jr., F. 2016. Site Characteristics Associated with Conventional and Unconventional Petroleum Development in West Virginia. West Virginia University. 


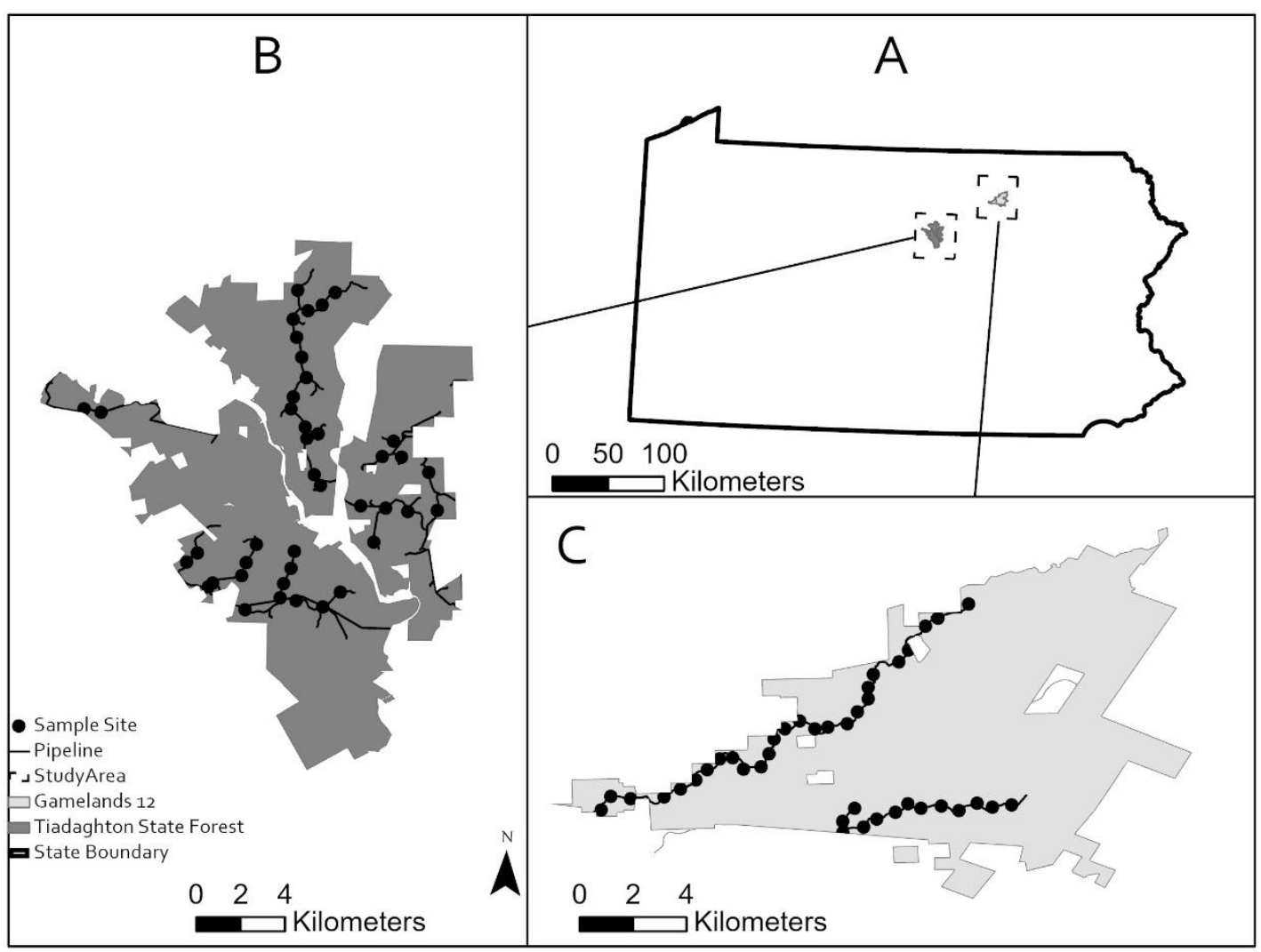

Figure 4.1: Location of main study sites in Pennsylvania (A). Site B is the Tiadaghton State Forest while C is PA state game lands 12. Study sites located on Pennsylvania Game Commission game lands 12.80 sample sites are evenly distributed between A and B. All pipelines in the Tiadaghton State Forest were constructed in 2013. There are 2 pipelines within the game lands site, the northern line completed in 2019 and the southern line completed in 2017 

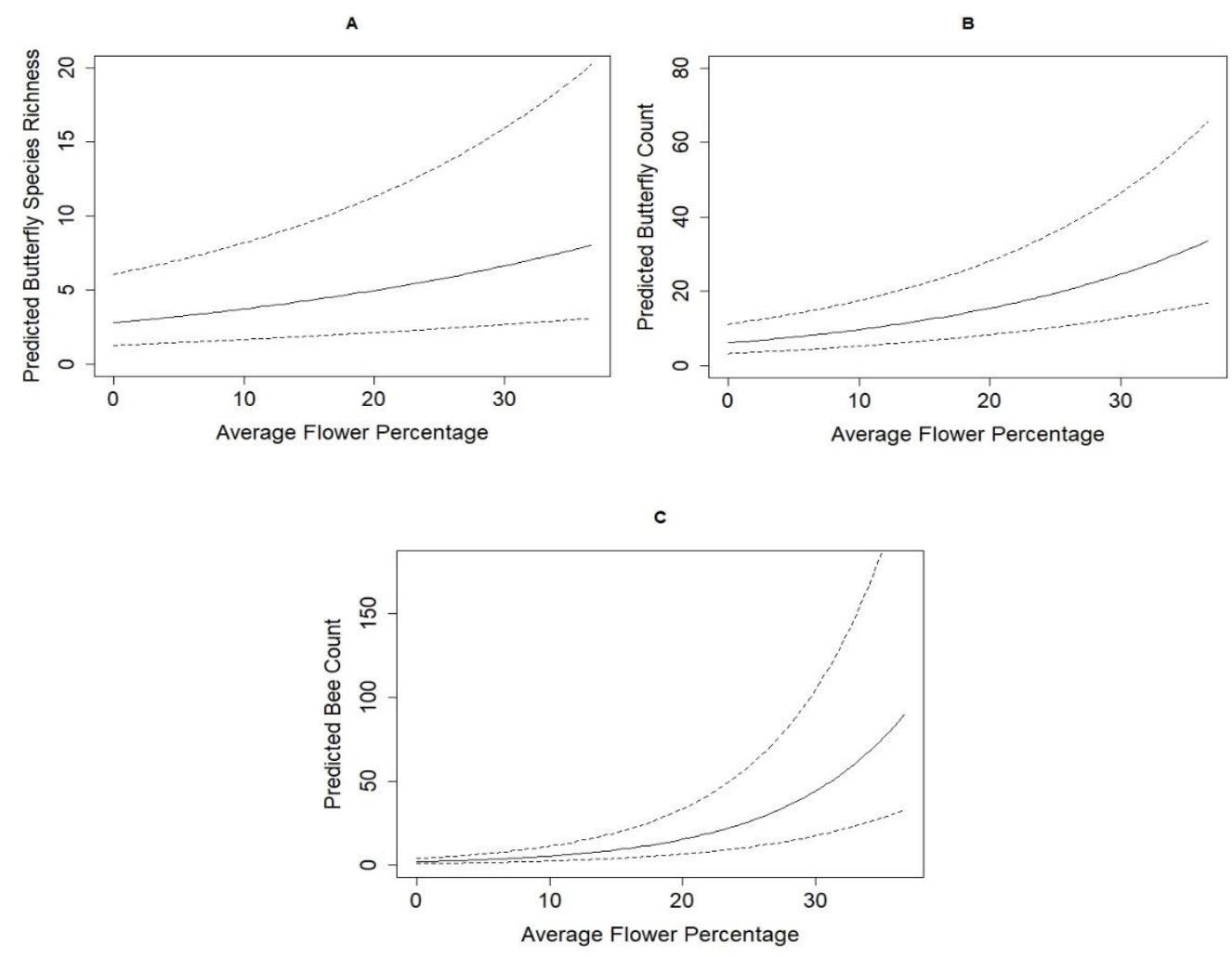

Figure 4.2 Predicted butterfly species richness, butterfly density, and bee density based on the percentage of flowers present on a natural gas pipeline ROW. Flower percentage was the best supported predictor for all pollinator metrics when modeled against ground cover, vegetation height, ROW age, and ROW width. 

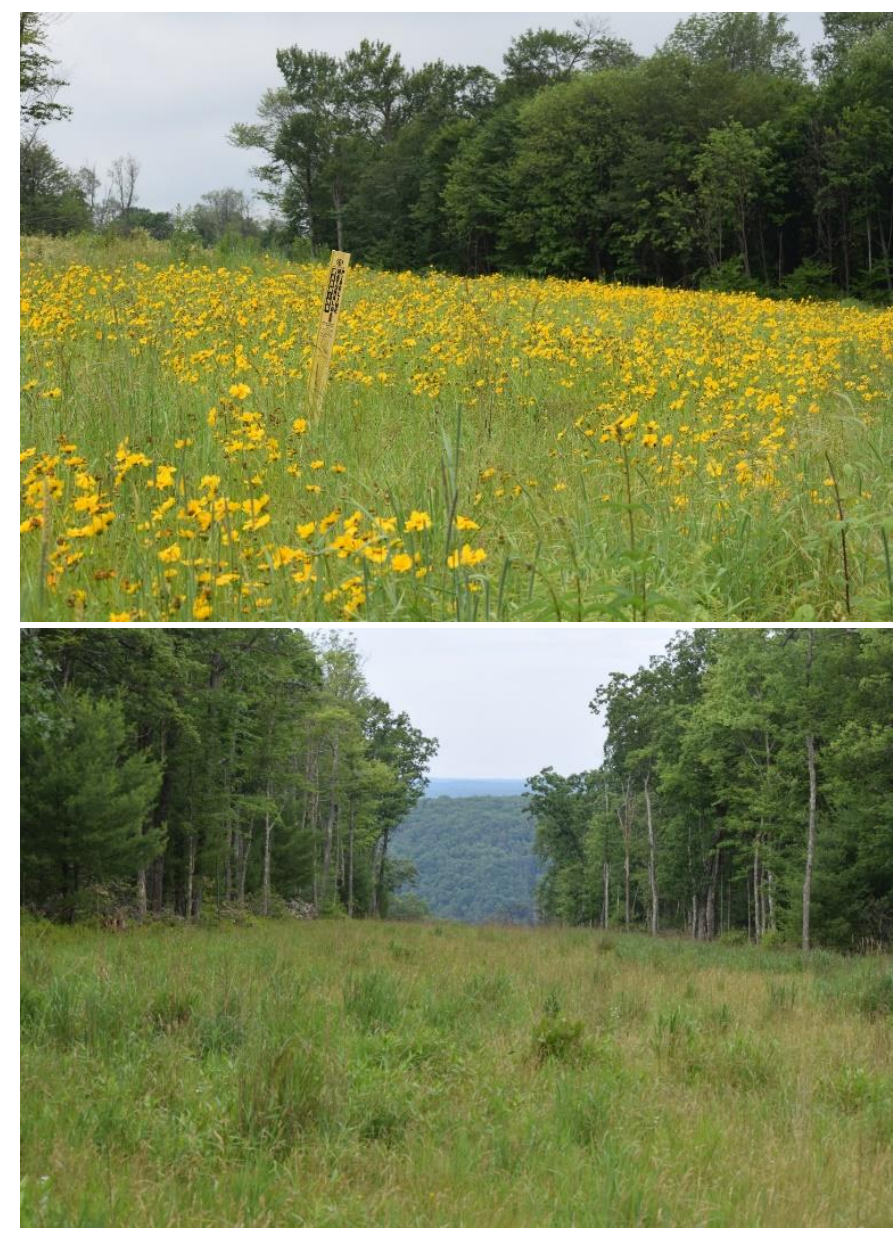

Figure 4.3: An example of natural gas pipeline right of ways (ROW) with large differences in flower percentage due to seed mix choice during reclamation. The ROW above had higher pollinator richness and density than the ROW below. 
Table 4.1: Covariates included in modeling to predict pollinator richness and density on a pipeline right of way (ROW) in Pennsylvania. Model sets tested included all covariates individually, a vegetation model with vegetation height, ground cover, and flower percentage, and a full model.

\begin{tabular}{lc}
\hline \multicolumn{1}{c}{ Covariate } & Description \\
\hline Vegetation Height & Maximum height of vegetation along ROW \\
Ground Cover & Percent of ROW covered with vegetation \\
Flower & Percentage of plants flowering at time of survey \\
Age & Years since ROW reclamation \\
ROW Width & Width of ROW \\
\hline
\end{tabular}


Table 4.2 Modeling results for butterfly richness, butterfly density, and bee density along natural gas pipeline ROWs in Pennsylvania. Model support was ranked using AICc, with top models assumed to be within $2 \triangle \mathrm{AICc}$ of the top model. Models within $7 \Delta \mathrm{AICc}$ are assumed to have some support. A Poisson distribution was used for butterfly richness, and a negative binomial distribution used for butterfly and bee density due to overdispersion.

Butterfly richness

\begin{tabular}{|c|c|c|c|}
\hline Model covariates & $\mathrm{AICc}$ & $\Delta \mathrm{AIC}$ & $\omega$ \\
\hline Veg Height + Ground Cover + Flower & 288.97 & 0 & 0.48 \\
\hline Flower & 289.75 & 0.78 & 0.32 \\
\hline Full Model & 290.77 & 1.8 & 0.19 \\
\hline Null & 302.93 & 13.96 & 0 \\
\hline Vegetation Height & 303.13 & 14.16 & 0 \\
\hline Age & 304.66 & 15.69 & 0 \\
\hline Ground Cover & 304.94 & 15.97 & 0 \\
\hline ROW Width & 305.01 & 16.05 & 0 \\
\hline Age + ROW Width & 306.64 & 17.67 & 0 \\
\hline \multicolumn{4}{|l|}{ Butterfly count } \\
\hline Model covariates & $\mathrm{AICc}$ & $\triangle \mathrm{AICc}$ & $\omega$ \\
\hline Flower & 499.43 & 0 & 0.61 \\
\hline Veg Height + Ground Cover + Flower & 501.88 & 2.08 & 0.21 \\
\hline Full & 537.8 & 2.45 & 0.18 \\
\hline Age & 538.01 & 38.36 & 0 \\
\hline Null & 538.06 & 38.57 & 0 \\
\hline Ground Cover & 538.91 & 38.63 & 0 \\
\hline ROW Width & 539.69 & 39.48 & 0 \\
\hline Vegetation Height & 539.69 & 40.26 & 0 \\
\hline Age + ROW Width & 539.76 & 40.33 & 0 \\
\hline \multicolumn{4}{|l|}{ Bee count } \\
\hline Model covariates & AIC & $\triangle \mathrm{AIC}$ & $\omega$ \\
\hline Flower & 475.53 & 0 & 0.83 \\
\hline Veg Height + Ground Cover + Flower & 478.93 & 3.4 & 0.15 \\
\hline Full & 482.93 & 7.4 & 0.02 \\
\hline Ground Cover & 537.14 & 61.61 & 0 \\
\hline Null & 543.22 & 67.69 & 0 \\
\hline Vegetation Height & 543.28 & 67.75 & 0 \\
\hline ROW Width & 544.77 & 69.24 & 0 \\
\hline Age & 545.37 & 69.84 & 0 \\
\hline Age + ROW Width & 546.69 & 71.16 & 0 \\
\hline
\end{tabular}




\section{Chapter 5}

Management Implications 


\section{Management Implications}

\subsection{Game birds and large mammals}

The low number of ruffed grouse (Bonasa umbellus) observed during surveys make it difficult to make any meaningful recommendations for pipeline ROW reclamation. In both study sites (Tiadaghton State Forest and Game Lands 12), actions were being performed to improve nesting habitat and cover for ruffed grouse. In Game Lands 12, multiple areas of 4-5 acres had been clear cut with the intention of improving grouse habitat, and this was done using funds received for the most recent pipeline construction on the property. I expect that these areas will provide better nesting habitat and vertical cover for grouse (Whitaker and Stauffer 2004, FelixLocher and Campa 2010). I also predict that ROWs can provide foraging habitat for broods, as grassland-type vegetation has been found to have larger insect and arthropod populations than open forest (Haulton 1999, Haulton et al. 2003). The number of eastern wild turkeys (Meleagris gallopavo) observed while traveling along pipelines can act as some evidence that they are useful to ground birds for foraging habitat (see figure 1). White-tailed deer (Odocoileus virginianus) were also seen foraging often while traveling along pipelines, and variation existed between study sites. Higher quality seed mixes on the Game Lands may be contributing to this difference, but further research is required to fully test this hypothesis. Previous work has been done on using warm season grasses in food plots, and the potential benefits for areas over-browsed by deer (Hehman and Fulbright 1997, Lashley et al. 2011).

\subsection{Salamanders and Snakes}

Eastern red backed salamanders (Plethodon cinereus) were less likely to be found on ROWs than in interior forest, which is consistent with previous work done on forest-dwelling terrestrial salamanders and forest fragmentation (Marsh and Beckman 2004, Marsh et al. 2005). 
The best predictor of salamander presence was the distance of cover boards from the center of the ROW, with occupancy probability increasing as distance increased. It is unlikely that the loss of habitat from a pipeline will have lasting effects on local populations, but there is a potential to segregate populations with new road construction. There is literature that shows roads as a barrier to population connectivity, but also shows terrestrial salamanders are capable of dispersing across open fields larger than the ROWs in this study (Marsh et al. 2004, 2005). Reintroducing coarse woody debris to ROWs following reclamation would benefit local salamander populations and other amphibians by providing cover. Salamanders were found to utilize coarse woody debris on powerline sites (Brannon et al. 2014).

Snakes were much more likely to occupy sites on the ROW than off it, in contrast to salamanders. Snakes often utilize edge habitat, and likely prefer ROWs for increased food density and higher solar radiation for improved thermoregulation. High prevalence of meadow voles (Microtus pennsylvanicus) and nests under coverboards on the ROW suggests that these areas provide ample food resources for larger rattlesnakes. Combined with rock structure creation, I anticipate that ROWs in the study area may be beneficial to local timber rattlesnake populations by providing food resources and hibernacula. It is possible, however, that increased heavy truck traffic and recreational traffic (due to improved roads during pipeline construction) may lead to higher road mortality and human-caused persecution of this species, but this would need to be studied in more detail to provide a definitive answer. In one study, human caused mortality and vehicle strikes were the second and third most common cause of death for timber rattlesnakes behind predation (Olson et al. 2015). 


\subsection{Pollinators}

Pollinator density and species richness was positively correlated with the percentage of flowering plants present. These findings are consistent with previous work measuring pollinators on utility ROWs (Berg et al. 2016, Eldegard et al. 2017a, Russo et al. 2021). Choosing seed mixes that prioritize flowering plants with different flowering schedules to maximize the extent of flower presence throughout the growing season will provide the best benefits to local pollinator populations. There was no interactive effect found between pollinator density and overall ROW width, suggesting that there is a linear relationship between pollinator abundance and habitat size. I expect that pollinator abundance will increase as the amount of flowers increases, meaning that pollinator abundance will be higher on wider ROWs assuming the percentage of flowering plants is the same.

\subsection{Overall Recommendations}

To provide the best benefit to wildlife, the results of this study indicate that prioritizing ROW siting along existing roads, along established early successional vegetation or within areas of young forest habitat. Natural gas pipeline ROWs in a forested setting will negatively impact terrestrial salamanders, but limiting new pipelines to existing roads or young forest will minimize these effects. A more costly approach would be to utilize horizontal directional drilling to created alternating patches of grassland and undisturbed forest over the pipeline (Allouche et al. 2000). Seed mixes used during reclamation should be chosen to maximize the number of flowers present throughout the growing season with warm and cool season grasses to provide structure and forage for larval pollinators (Figures 5.2, 5.3). Seed mixes should also include only native species, and care taken to deter the introduction or expansion of any invasive plant species. The temporary workspace of the ROW can be replanted with fruiting native trees and 
shrubs which will provide food resources for wildlife species and reduce edge effects on (Figure 5.4). Rock structures located along ROW edges can also be created to provide hibernacula for snakes (Figure 5.5). Siting and reclamation of pipelines that follow these recommendations will provide benefits to wildlife and limit the negative effects that forest fragmentation has on others. Right of way width negatively effects salamanders, but is beneficial to pollinators assuming a quality seed mix is used. This highlights the anachronism of a ROW in a forested landscape; some species will benefit and others suffer regardless of ROW location or reclamation. It is up to the local land manager to determine prioritization of species' needs. 


\section{Literature cited}

Allouche, E. N., S. T. Araratnam, and J. S. Lueke. 2000. Horizontal Directional Drilling: Profile of an Emerging Industry. Journal of Construction Engineering and Management 126:68-76.

Berg, Å., K. O. Bergman, J. Wissman, M. Żmihorski, and E. Öckinger. 2016. Power-line corridors as source habitat for butterflies in forest landscapes. Biological Conservation 201:320-326.

Brannon, P., E. C. Allan, and M. C. Silinski. 2014. Terrestrial Salamander Abundances Along and Within an Electric Power Line Right-of-Way. Journal of the North Carolina Academy of Science 132:40-45.

Eldegard, K., D. L. Eyitayo, M. H. Lie, and S. R. Moe. 2017. Can powerline clearings be managed to promote insect-pollinated plants and species associated with semi-natural grasslands? Landscape and Urban Planning 167:419-428. Elsevier. <http://dx.doi.org/10.1016/j.landurbplan.2017.07.017>.

Felix-Locher, A., and H. Campa. 2010. Importance of habitat type classifications for predicting ruffed grouse use of areas for drumming. Forest Ecology and Management 259:1464-1471. Elsevier B.V. 〈http://dx.doi.org/10.1016/j.foreco.2010.01.020>.

Haulton, G. S. 1999. Ruffed Grouse Natality, Chick Survival, and Brood Micro-Habitat Selection in the Southern Appalachians. Virginia Polytechnic Institute and State University.

Haulton, G. S., F. Stauffer, R. L. Kirkpatrick, and G. W. Norman. 2003. Ruffed Grouse ( Bonasa umbellus ) Brood Microhabitat Selection in the Southern Appalachians. The American Midland Naturalist 150:95-103.

Hehman, M. W., and T. E. Fulbright. 1997. Use of Warm-Season Food Plots by White-Tailed Deer. The Journal of Wildlife Management 61:1108-1115.

Lashley, M. A., C. A. Harper, G. E. Bates, and P. D. Keyser. 2011. Forage availability for whitetailed deer following silvicultural treatments in hardwood forests. Journal of Wildlife Management 75:1467-1476.

Marsh, D. M., and N. G. Beckman. 2004. Effects of forest roads on the abundance and activity of terrestrial salamanders. Ecological Applications 14:1882-1891.

Marsh, D. M., G. S. Milam, N. P. Gorham, and N. G. Beckman. 2005. Forest roads as partial barriers to terrestrial salamander movement. Conservation Biology 19:2004-2008.

Marsh, D. M., K. A. Thakur, K. C. Bulka, and L. B. Clarke. 2004. Dispersal and colonization through open fields by a terrestrial, woodland salamander. Ecology 85:3396-3405.

Olson, Z. H., B. J. MacGowan, M. T. Hamilton, A. F. T. Currylow, and R. N. Williams. 2015. Survival of Timber Rattlesnakes (Crotalus horridus): Investigating Individual, Environmental, and Ecological Effects. Herpetologica 71:274-279.

Russo, L., H. Stout, D. Roberts, B. D. Ross, and C. G. Mahan. 2021. Powerline right-of-way management and flower-visiting insects : How vegetation management can promote pollinator diversity. PLoS ONE 1-17. <http://dx.doi.org/10.1371/journal.pone.0245146>. 
Whitaker, D. M., and D. F. Stauffer. 2004. Ruffed grouse (Bonasa umbellus) habitat ecology in the central and southern Appalachians. ProQuest Dissertations and Theses $220 \mathrm{p}$. <http://ezproxy.usherbrooke.ca/login?url=http://search.proquest.com/docview/305105487?a ccountid=13835 L2 - http://sfxhosted.exlibrisgroup.com/sherbrooke?url_ver=Z39.88-

2004\&rft_val_fmt=info:ofi/fmt:kev:mtx:dissertation\&genre=dissertations+\%26+theses\&sid $=\mathrm{P}>$. 


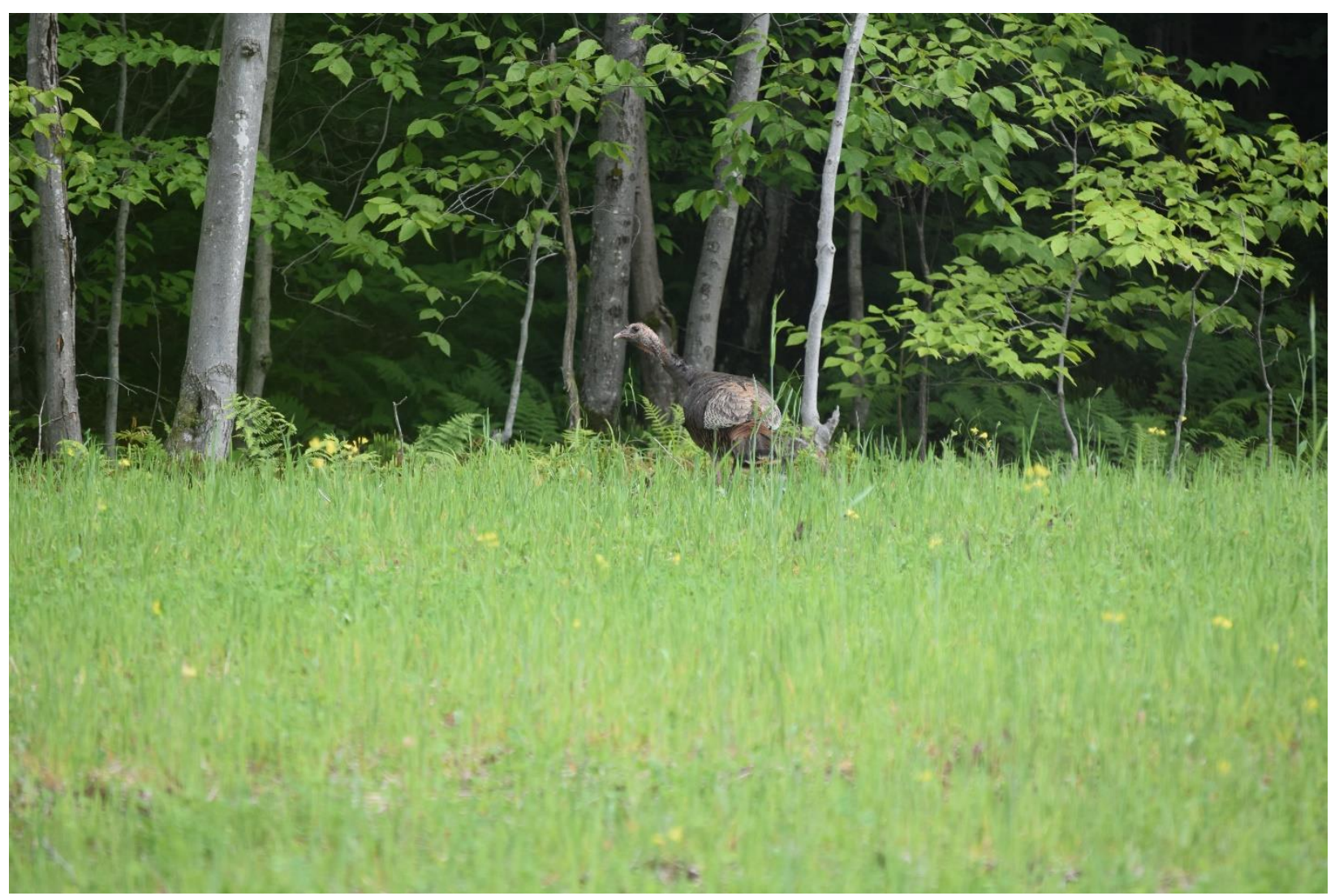

Figure 5.1: Eastern wild turkey (Meleagris gallopavo) hen observed on a pipeline ROW. 


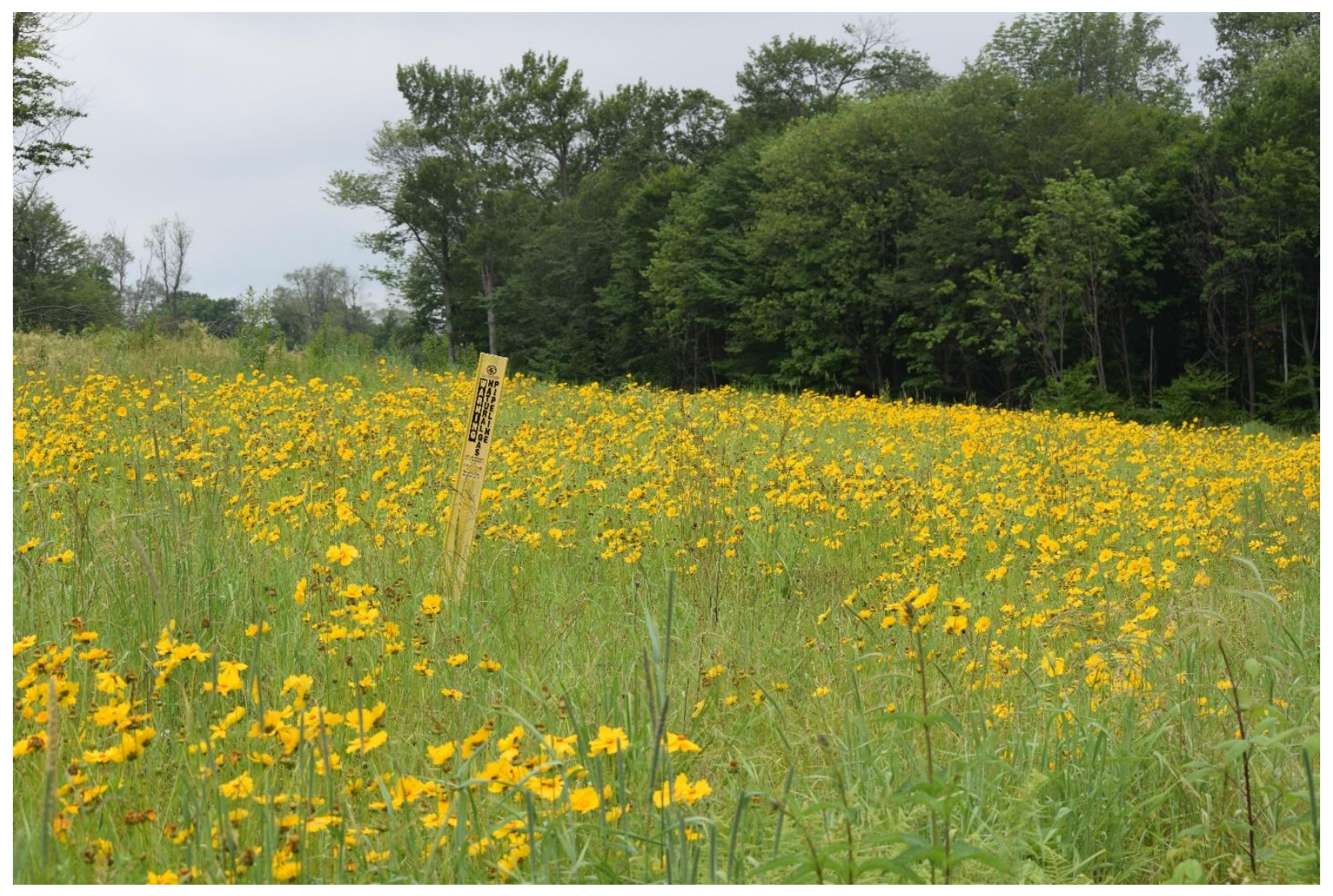

Figure 5.2: Pipeline right of way with high pollinator density and high flower percentage. 


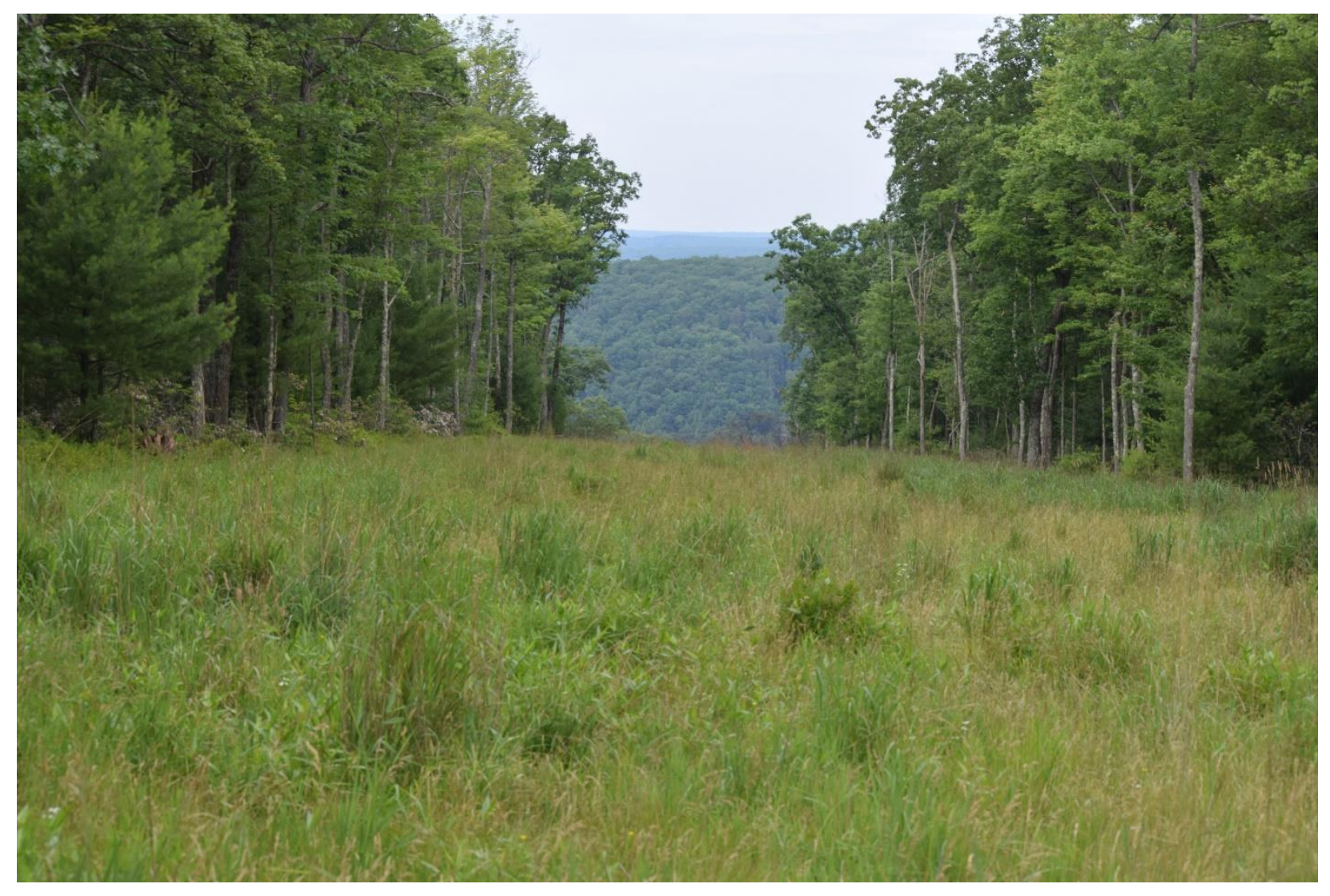

Figure 5.3 Pipeline right of way on the Tiadaghton State Forest with low pollinator density, poor vegetation diversity, and no flower growth. 


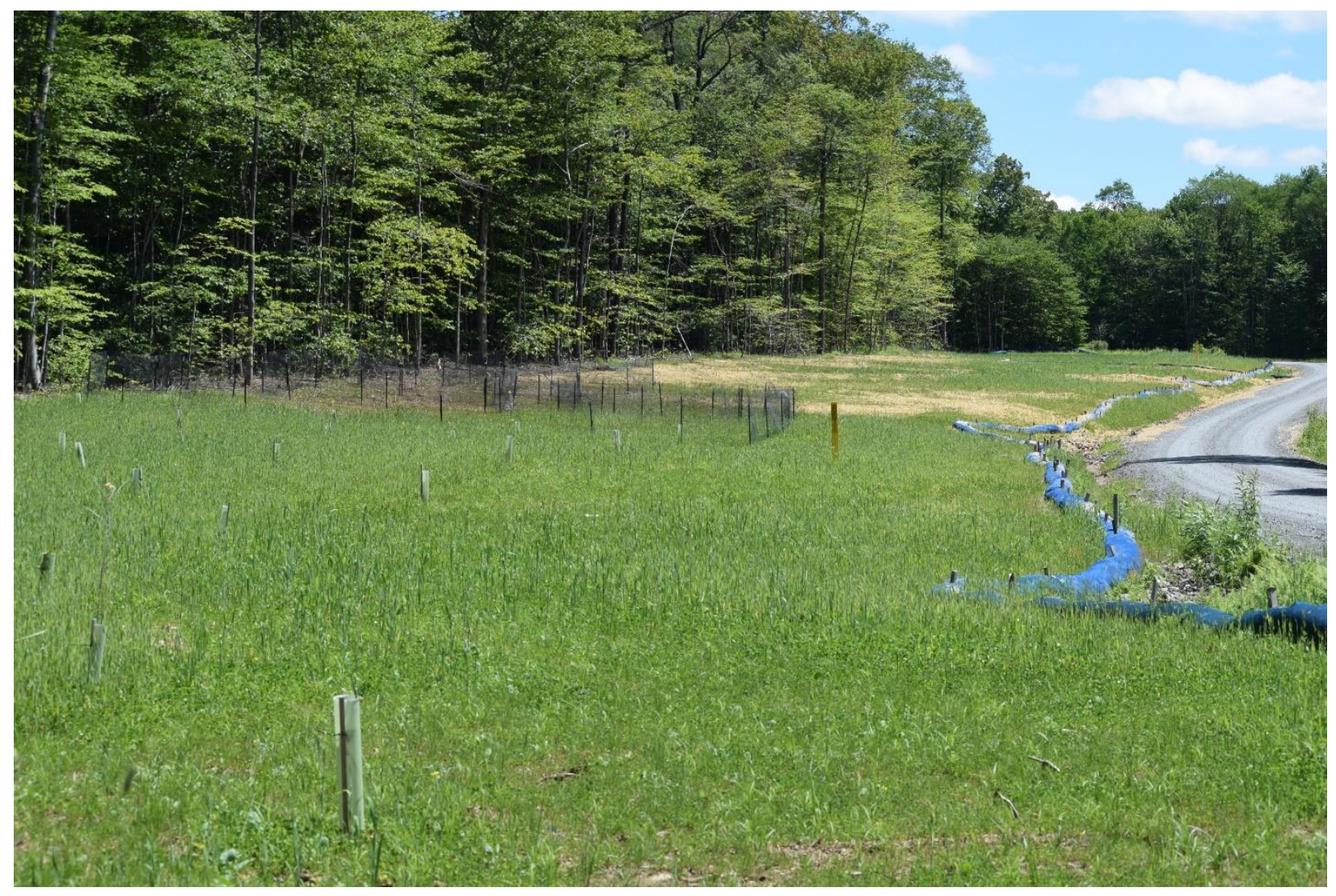

Figure 5.4: An example of a natural gas pipeline ROW temporary workspace that has been replanted with trees and shrubs, and the pipeline routed along an existing road. The pipeline is positioned in line with the yellow marker, visible in the center right portion of the photograph. 


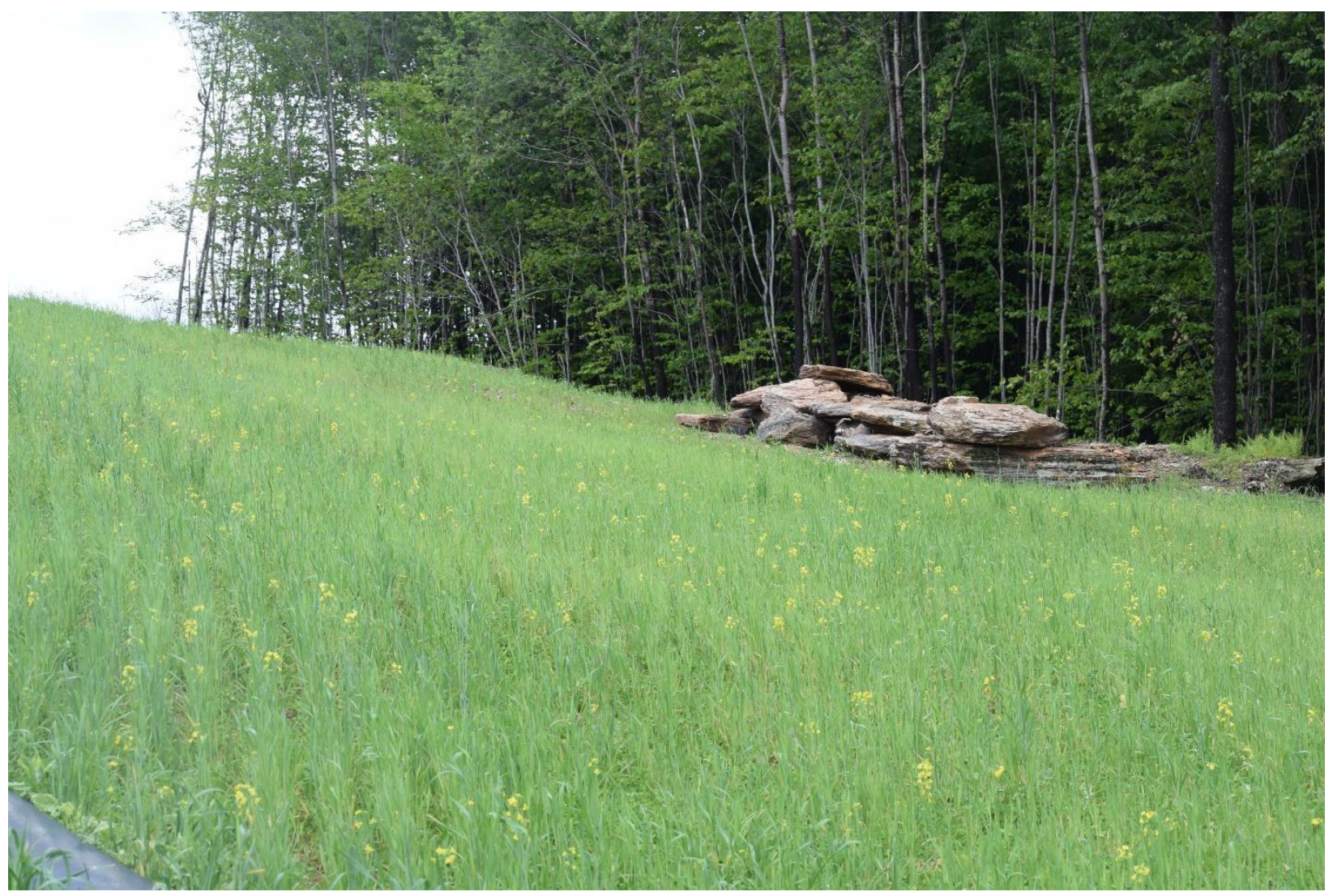

Figure 5.5 Example of a rock structure constructed along a natural gas pipeline ROW to provide hibernacula for snakes. 
Appendix A: Study site locations, ROW Age (years, ROW width (in metes, with and without a road), and seed mix of each site (sites $4 \mathrm{~A}-30 \mathrm{~A})$.

\begin{tabular}{|c|c|c|c|c|c|c|c|}
\hline ID & UTME & UTMN & Age & $\begin{array}{l}\text { Total ROW } \\
\text { width }\end{array}$ & $\begin{array}{l}\text { ROW } \\
\text { Width }\end{array}$ & Road & $\begin{array}{l}\text { seed } \\
\text { mix }\end{array}$ \\
\hline $1 \mathrm{~A}$ & 356428 & 4604740 & 3 & 30 & 30 & 0 & \\
\hline $2 \mathrm{~A}$ & 356422 & 4605152 & 3 & 33 & 12 & 1 & \\
\hline $3 \mathrm{~A}$ & 356741 & 4605596 & 3 & 26 & 11 & 1 & \\
\hline $4 \mathrm{~A}$ & 349660 & 4605727 & 1 & 32 & 32 & 0 & 1 \\
\hline $5 \mathrm{~A}$ & 349869 & 4606190 & 1 & 30 & 30 & 0 & 1 \\
\hline $6 \mathrm{~A}$ & 350507 & 4606131 & 1 & 41 & 25 & 1 & 1 \\
\hline $7 \mathrm{~A}$ & 351436 & 4606172 & 1 & 35 & 28 & 1 & 3 \\
\hline $8 \mathrm{~A}$ & 351912 & 4606467 & 1 & 35 & 26 & 1 & 5 \\
\hline $9 \mathrm{~A}$ & 352335 & 4606800 & 1 & 35 & 18 & 1 & 13 \\
\hline $10 \mathrm{~A}$ & 352672 & 4607171 & 1 & 32 & 23 & 1 & 9 \\
\hline $11 \mathrm{~A}$ & 353033 & 4607568 & 1 & 40 & 16 & 1 & 15 \\
\hline $12 \mathrm{~A}$ & 353398 & 4607588 & 1 & 28 & 19 & 1 & 15 \\
\hline $13 \mathrm{~A}$ & 353686 & 4607176 & 1 & 38 & 38 & 0 & 16 \\
\hline $14 \mathrm{~A}$ & 354183 & 4607236 & 1 & 28 & 16 & 1 & 6 \\
\hline $15 \mathrm{~A}$ & 354419 & 4607720 & 1 & 42 & 24 & 1 & 15 \\
\hline $16 \mathrm{~A}$ & 354571 & 4608269 & 1 & 34 & 26 & 1 & 15 \\
\hline $17 \mathrm{~A}$ & 354872 & 4608640 & 1 & 38 & 26 & 1 & 3 \\
\hline $18 \mathrm{~A}$ & 355292 & 4608945 & 1 & 33 & 17 & 1 & 9 \\
\hline $19 \mathrm{~A}$ & 355721 & 4608627 & 1 & 38 & 25 & 1 & 3 \\
\hline $20 \mathrm{~A}$ & 356081 & 4608689 & 1 & 34 & 18 & 1 & 6 \\
\hline $21 \mathrm{~A}$ & 356636 & 4608803 & 1 & 36 & 25 & 1 & 5 \\
\hline $22 \mathrm{~A}$ & 356926 & 4609246 & 1 & 35 & 22 & 1 & 6 \\
\hline $23 \mathrm{~A}$ & 357230 & 4609733 & 1 & 41 & 21 & 1 & 2 \\
\hline $24 \mathrm{~A}$ & 357238 & 4610151 & 1 & 25 & 10 & 1 & 6 \\
\hline $25 \mathrm{~A}$ & 357393 & 4610620 & 1 & 115 & 115 & 0 & 2 \\
\hline $26 \mathrm{~A}$ & 358117 & 4611077 & 1 & 30 & 30 & 0 & 16 \\
\hline $27 \mathrm{~A}$ & 358398 & 4611525 & 1 & 44 & 29 & 1 & 3 \\
\hline $28 \mathrm{~A}$ & 358889 & 4612409 & 1 & 33 & 33 & 0 & 7 \\
\hline $29 \mathrm{~A}$ & 359252 & 4612699 & 1 & 37 & 37 & 0 & 2 \\
\hline $30 \mathrm{~A}$ & 360116 & 4613211 & 1 & 46 & 32 & 1 & 10 \\
\hline $31 \mathrm{~A}$ & 357907 & 4605468 & 3 & 27 & 11 & 1 & \\
\hline $32 \mathrm{~A}$ & 357385 & 4605223 & 3 & 26 & 12 & 1 & \\
\hline $33 \mathrm{~A}$ & 357007 & 4604933 & 3 & 25 & 13 & 1 & \\
\hline $34 \mathrm{~A}$ & 358275 & 4605777 & 3 & 28 & 16 & 1 & \\
\hline $35 \mathrm{~A}$ & 358638 & 4605611 & 3 & 29 & 11 & 1 & \\
\hline $36 \mathrm{~A}$ & 359210 & 4605677 & 3 & 25 & 11 & 1 & \\
\hline
\end{tabular}




\begin{tabular}{|c|c|c|c|c|c|c|}
\hline $37 \mathrm{~A}$ & 359692 & 4605510 & 3 & 35 & 20 & 1 \\
\hline $38 \mathrm{~A}$ & 360209 & 4605762 & 3 & 30 & 20 & 1 \\
\hline $39 \mathrm{~A}$ & 360639 & 4605599 & 3 & 27 & 18 & 1 \\
\hline $40 \mathrm{~A}$ & 361182 & 4605679 & 3 & 28 & 18 & 1 \\
\hline 1B & 298097 & 4572270 & 7 & 30 & 11 & 1 \\
\hline $2 \mathrm{~B}$ & 299732 & 4573050 & 7 & 26 & 12 & 1 \\
\hline $3 \mathrm{~B}$ & 299839 & 4573440 & 7 & 17 & 13 & 1 \\
\hline $4 \mathrm{~B}$ & 301582 & 4572370 & 7 & 16 & 10 & 1 \\
\hline $5 B$ & 300393 & 4572670 & 7 & 16 & 10 & 1 \\
\hline $6 B$ & 302391 & 4573040 & 7 & 22 & 10 & 1 \\
\hline $7 \mathrm{~B}$ & 296642 & 4573450 & 7 & 20 & 13 & 1 \\
\hline $8 B$ & 297949 & 4573790 & 7 & 32 & 12 & 1 \\
\hline $9 \mathrm{~B}$ & 298141 & 4574360 & 7 & 27 & 15 & 1 \\
\hline 10B & 295483 & 4574400 & 7 & 23 & 13 & 1 \\
\hline $11 \mathrm{~B}$ & 295945 & 4574790 & 7 & 30 & 18 & 1 \\
\hline $12 \mathrm{~B}$ & 300153 & 4574110 & 7 & 17 & 11 & 1 \\
\hline $13 \mathrm{~B}$ & 300309 & 4574880 & 7 & 18 & 10 & 1 \\
\hline 14B & 298562 & 4575520 & 7 & 24 & 14 & 1 \\
\hline 17B & 304330 & 4576785 & 7 & 35 & 24 & 1 \\
\hline $18 \mathrm{~B}$ & 303886 & 4575300 & 7 & 25 & 14 & 1 \\
\hline 19B & 305415 & 4576660 & 7 & 21 & 12 & 1 \\
\hline $20 \mathrm{~B}$ & 303296 & 4576920 & 7 & 20 & 20 & 0 \\
\hline $21 \mathrm{~B}$ & 306736 & 4576720 & 7 & 25 & 16 & 1 \\
\hline $22 B$ & 301313 & 4577665 & 7 & 34 & 13 & 1 \\
\hline $23 B$ & 301215 & 4578320 & 7 & 45 & 45 & 0 \\
\hline $24 \mathrm{~B}$ & 304259 & 4579140 & 7 & 24 & 10 & 1 \\
\hline $25 \mathrm{~B}$ & 305124 & 4579120 & 7 & 25 & 10 & 1 \\
\hline $26 \mathrm{~B}$ & 306364 & 4578420 & 7 & 24 & 17 & 1 \\
\hline $27 \mathrm{~B}$ & 300880 & 4579960 & 7 & 25 & 17 & 1 \\
\hline $28 \mathrm{~B}$ & 291613 & 4581120 & 7 & 34 & 18 & 1 \\
\hline 29B & 290853 & 4581270 & 7 & 20 & 20 & 0 \\
\hline 30B & 304770 & 4579830 & 7 & 25 & 10 & 1 \\
\hline $31 \mathrm{~B}$ & 301379 & 4580170 & 7 & 22 & 13 & 1 \\
\hline $32 \mathrm{~B}$ & 300817 & 4580412 & 7 & 26 & 14 & 1 \\
\hline $33 \mathrm{~B}$ & 300368 & 4581057 & 7 & 28 & 15 & 1 \\
\hline $34 \mathrm{~B}$ & 300252 & 4581820 & 7 & 26 & 21 & 1 \\
\hline $35 \mathrm{~B}$ & 300844 & 4582680 & 7 & 33 & 16 & 1 \\
\hline $36 \mathrm{~B}$ & 300640 & 4583590 & 7 & 33 & 18 & 1 \\
\hline $37 \mathrm{~B}$ & 300412 & 4584480 & 7 & 24 & 14 & 1 \\
\hline $38 \mathrm{~B}$ & 300265 & 4585300 & 7 & 26 & 15 & 1 \\
\hline $39 \mathrm{~B}$ & 300924 & 4585680 & 7 & 38 & 12 & 1 \\
\hline
\end{tabular}




\begin{tabular}{lllllll}
\hline 40B & 301563 & 4585930 & 7 & 25 & 13 & 1 \\
41B & 302140 & 4586510 & 7 & 26 & 16 & 1 \\
42B & 300459 & 4586600 & 7 & 26 & 15 & 1 \\
\hline
\end{tabular}


Appendix B: Survey date and time for ruffed grouse, cover board searches for salamanders and snakes, and pollinators. Ruffed grouse observations are also included for each survey $(0-$ not observed, $1-$ observed). Start time of surveys is using a 24 hour clock, and duration is in minutes.

\begin{tabular}{|c|c|c|c|c|c|c|c|c|c|}
\hline & & & Grouse & Survey & & Herp & Survey & Pollinator & Survey \\
\hline Site & Survey & Date & Start & Duration & Grouse Obs & Start & Duration & Start & Duration \\
\hline \multirow[t]{4}{*}{$1 \mathrm{a}$} & 1 & $5 / 21 / 2019$ & $9: 05$ & 7 & 0 & & & $9: 12$ & 8 \\
\hline & 2 & $6 / 21 / 2019$ & $9: 20$ & 8 & 0 & & & $9: 28$ & 12 \\
\hline & 3 & $7 / 5 / 2019$ & $9: 23$ & 7 & 0 & & & $9: 30$ & 13 \\
\hline & 4 & $7 / 22 / 2019$ & $14: 45$ & 9 & 0 & & & 9:06 & 17 \\
\hline \multirow[t]{4}{*}{$2 \mathrm{a}$} & 1 & $5 / 23 / 2019$ & $9: 25$ & 9 & 0 & & & $9: 34$ & 7 \\
\hline & 2 & $6 / 19 / 2019$ & 10:08 & 7 & 0 & & & $10: 15$ & 15 \\
\hline & 3 & $7 / 8 / 2019$ & $9: 50$ & 9 & 0 & & & $9: 59$ & 12 \\
\hline & 4 & $7 / 29 / 2019$ & $9: 30$ & 8 & 0 & & & $9: 38$ & 13 \\
\hline \multirow[t]{4}{*}{$3 a$} & 1 & $5 / 23 / 2019$ & $9: 43$ & 6 & 0 & & & $9: 49$ & 13 \\
\hline & 2 & $6 / 10 / 2019$ & 9:01 & 8 & 0 & & & 9:09 & 14 \\
\hline & 3 & $7 / 5 / 2019$ & $9: 54$ & 8 & 0 & & & $10: 02$ & 16 \\
\hline & 4 & $7 / 25 / 2019$ & 10:00 & 8 & 0 & & & 10:08 & 17 \\
\hline \multirow[t]{4}{*}{$4 a$} & 1 & $5 / 21 / 2019$ & $11: 10$ & 6 & 0 & & & $11: 16$ & 15 \\
\hline & 2 & $6 / 20 / 2019$ & $9: 10$ & 8 & 0 & & & $9: 18$ & 12 \\
\hline & 3 & 7/8/2019 & $12: 31$ & 7 & 0 & & & $12: 38$ & 13 \\
\hline & 4 & $7 / 29 / 2019$ & $13: 30$ & 7 & 0 & & & $13: 37$ & 14 \\
\hline \multirow[t]{4}{*}{$5 a$} & 1 & $5 / 23 / 2019$ & 11:01 & 10 & 0 & & & 11:11 & 13 \\
\hline & 2 & $6 / 19 / 2019$ & $11: 40$ & 5 & 0 & & & $11: 45$ & 15 \\
\hline & 3 & 7/1/2019 & 9:10 & 8 & 0 & & & $9: 18$ & 12 \\
\hline & 4 & $7 / 22 / 2019$ & $12: 30$ & 9 & 0 & & & $14: 00$ & 15 \\
\hline \multirow[t]{4}{*}{$6 a$} & 1 & $5 / 22 / 2019$ & $8: 19$ & 6 & 0 & & & $11: 20$ & 12 \\
\hline & 2 & $6 / 10 / 2019$ & $10: 01$ & 7 & 0 & & & $10: 08$ & 12 \\
\hline & 3 & 7/3/2019 & $10: 45$ & 7 & 0 & & & $10: 52$ & 14 \\
\hline & 4 & $7 / 25 / 2019$ & $11: 40$ & 8 & 0 & & & $11: 48$ & 15 \\
\hline \multirow[t]{4}{*}{$7 \mathrm{a}$} & 1 & $5 / 31 / 2019$ & $11: 59$ & 9 & 0 & & & $12: 08$ & 20 \\
\hline & 2 & $6 / 19 / 2019$ & $12: 14$ & 6 & 0 & & & $12: 20$ & 15 \\
\hline & 3 & $7 / 5 / 2019$ & $13: 58$ & 8 & 0 & & & 14:06 & 16 \\
\hline & 4 & $7 / 26 / 2019$ & $7: 46$ & 9 & 0 & & & 9:59 & 11 \\
\hline \multirow[t]{4}{*}{$8 \mathrm{a}$} & 1 & $5 / 24 / 2019$ & $7: 55$ & 10 & 0 & & & $11: 35$ & 15 \\
\hline & 2 & $6 / 10 / 2019$ & $8: 53$ & 9 & 0 & & & 9:02 & 12 \\
\hline & 3 & 7/3/2019 & $11: 21$ & 8 & 0 & & & $11: 29$ & 14 \\
\hline & 4 & $7 / 26 / 2019$ & $8: 33$ & 9 & 0 & & & 9:46 & 13 \\
\hline \multirow[t]{3}{*}{$9 a$} & 1 & $5 / 31 / 2019$ & $11: 10$ & 10 & 0 & & & $11: 20$ & 14 \\
\hline & 2 & $6 / 20 / 2019$ & $10: 10$ & 8 & 0 & & & $10: 18$ & 12 \\
\hline & 3 & 7/8/2019 & $15: 39$ & 7 & 0 & & & $15: 46$ & 14 \\
\hline
\end{tabular}




\begin{tabular}{|c|c|c|c|c|c|c|c|}
\hline & 4 & $7 / 30 / 2019$ & $9: 10$ & 6 & 0 & $9: 16$ & 15 \\
\hline \multirow[t]{4}{*}{$10 \mathrm{a}$} & 1 & $5 / 31 / 2019$ & $10: 35$ & 7 & 0 & $10: 42$ & 16 \\
\hline & 2 & $6 / 20 / 2019$ & $10: 40$ & 6 & 0 & $10: 46$ & 14 \\
\hline & 3 & 7/1/2019 & $9: 49$ & 10 & 0 & $9: 59$ & 14 \\
\hline & 4 & $7 / 25 / 2019$ & $12: 23$ & 7 & 0 & $12: 30$ & 15 \\
\hline \multirow[t]{4}{*}{$11 \mathrm{a}$} & 1 & $5 / 21 / 2019$ & $10: 18$ & 10 & 0 & $10: 30$ & 12 \\
\hline & 2 & $6 / 28 / 2019$ & $16: 35$ & 7 & 0 & $16: 42$ & 18 \\
\hline & 3 & 7/5/2019 & $13: 21$ & 6 & 1 & $13: 27$ & 13 \\
\hline & 4 & $7 / 25 / 2019$ & $13: 21$ & 8 & 0 & $13: 29$ & 17 \\
\hline \multirow[t]{4}{*}{$12 \mathrm{a}$} & 1 & $5 / 24 / 2019$ & $8: 18$ & 8 & 0 & $11: 20$ & 15 \\
\hline & 2 & $6 / 20 / 2019$ & $11: 12$ & 8 & 0 & $11: 20$ & 14 \\
\hline & 3 & 7/3/2019 & $12: 34$ & 6 & 0 & $12: 40$ & 13 \\
\hline & 4 & $7 / 26 / 2019$ & $8: 58$ & 7 & 0 & 9:05 & 18 \\
\hline \multirow[t]{4}{*}{$13 a$} & 1 & $5 / 23 / 2019$ & $11: 35$ & 6 & 0 & $11: 41$ & 9 \\
\hline & 2 & $6 / 20 / 2019$ & $12: 00$ & 7 & 0 & 12:07 & 13 \\
\hline & 3 & $7 / 1 / 2019$ & $10: 34$ & 7 & 0 & $10: 41$ & 17 \\
\hline & 4 & $7 / 22 / 2019$ & $8: 10$ & 9 & 0 & $9: 40$ & 12 \\
\hline \multirow[t]{4}{*}{$14 \mathrm{a}$} & 1 & $5 / 23 / 2019$ & $12: 05$ & 7 & 0 & $12: 12$ & 9 \\
\hline & 2 & $6 / 20 / 2019$ & $12: 32$ & 6 & 0 & $12: 38$ & 14 \\
\hline & 3 & $7 / 5 / 2019$ & $12: 52$ & 6 & 0 & $12: 58$ & 12 \\
\hline & 4 & $7 / 22 / 2019$ & $8: 37$ & 10 & 0 & $9: 56$ & 9 \\
\hline \multirow[t]{4}{*}{$15 \mathrm{a}$} & 1 & $5 / 24 / 2019$ & $8: 44$ & 8 & 0 & $8: 55$ & 15 \\
\hline & 2 & $6 / 19 / 2019$ & $12: 58$ & 7 & 0 & 13:05 & 12 \\
\hline & 3 & 7/3/2019 & 13:06 & 6 & 0 & $13: 12$ & 9 \\
\hline & 4 & $7 / 25 / 2019$ & $14: 06$ & 10 & 0 & $14: 16$ & 16 \\
\hline \multirow[t]{4}{*}{$16 \mathrm{a}$} & 1 & $5 / 22 / 2019$ & 9:05 & 10 & 0 & $9: 15$ & 14 \\
\hline & 2 & $6 / 19 / 2019$ & $13: 30$ & 8 & 0 & $13: 38$ & 14 \\
\hline & 3 & 7/8/2019 & $14: 58$ & 5 & 0 & $15: 03$ & 12 \\
\hline & 4 & $7 / 30 / 2019$ & $10: 10$ & 5 & 0 & $10: 15$ & 15 \\
\hline \multirow[t]{4}{*}{$17 \mathrm{a}$} & 1 & $5 / 21 / 2019$ & $9: 43$ & 8 & 0 & $11: 48$ & 18 \\
\hline & 2 & $6 / 19 / 2019$ & $14: 10$ & 6 & 0 & $14: 16$ & 14 \\
\hline & 3 & 7/3/2019 & $13: 40$ & 6 & 0 & $13: 46$ & 14 \\
\hline & 4 & $7 / 25 / 2019$ & $14: 39$ & 7 & 0 & $14: 46$ & 12 \\
\hline \multirow[t]{4}{*}{$18 \mathrm{a}$} & 1 & $5 / 24 / 2019$ & $9: 30$ & 8 & 0 & $9: 38$ & 13 \\
\hline & 2 & $6 / 10 / 2019$ & $10: 34$ & 8 & 0 & $10: 42$ & 18 \\
\hline & 3 & $7 / 10 / 2019$ & $8: 21$ & 8 & 0 & $11: 38$ & 16 \\
\hline & 4 & $7 / 30 / 2019$ & $10: 40$ & 7 & 0 & $10: 47$ & 13 \\
\hline \multirow[t]{4}{*}{$19 a$} & 1 & $5 / 31 / 2019$ & $9: 58$ & 10 & 0 & 10:08 & 14 \\
\hline & 2 & $6 / 20 / 2019$ & 13:08 & 6 & 0 & $13: 14$ & 16 \\
\hline & 3 & $7 / 10 / 2019$ & $8: 58$ & 12 & 0 & $11: 16$ & 13 \\
\hline & 4 & $7 / 30 / 2019$ & $11: 05$ & 6 & 0 & $11: 11$ & 16 \\
\hline
\end{tabular}




\begin{tabular}{|c|c|c|c|c|c|c|c|}
\hline \multirow[t]{4}{*}{$20 \mathrm{a}$} & 1 & $5 / 21 / 2019$ & $8: 25$ & 6 & 0 & $12: 14$ & 16 \\
\hline & 2 & $6 / 18 / 2019$ & 16:01 & 5 & 0 & $16: 06$ & 14 \\
\hline & 3 & $7 / 1 / 2019$ & $11: 24$ & 6 & 0 & $11: 30$ & 13 \\
\hline & 4 & $7 / 22 / 2019$ & $10: 46$ & 8 & 0 & $11: 31$ & 9 \\
\hline \multirow[t]{4}{*}{$21 \mathrm{a}$} & 1 & $5 / 24 / 2019$ & $10: 05$ & 7 & 0 & $10: 12$ & 10 \\
\hline & 2 & $6 / 10 / 2019$ & $12: 34$ & 7 & 0 & $12: 41$ & 10 \\
\hline & 3 & $7 / 8 / 2019$ & $14: 20$ & 6 & 0 & $14: 26$ & 14 \\
\hline & 4 & $7 / 30 / 2019$ & $11: 43$ & 7 & 0 & $11: 50$ & 13 \\
\hline \multirow[t]{4}{*}{$22 \mathrm{a}$} & 1 & $5 / 22 / 2019$ & $9: 50$ & 8 & 0 & $9: 58$ & 11 \\
\hline & 2 & $6 / 18 / 2019$ & $15: 29$ & 6 & 0 & $15: 35$ & 15 \\
\hline & 3 & 7/3/2019 & $14: 20$ & 8 & 0 & $14: 28$ & 14 \\
\hline & 4 & $7 / 26 / 2019$ & $11: 38$ & 8 & 0 & $11: 46$ & 14 \\
\hline \multirow[t]{4}{*}{$23 a$} & 1 & $5 / 22 / 2019$ & $10: 20$ & 5 & 0 & $10: 25$ & 9 \\
\hline & 2 & $6 / 10 / 2019$ & $9: 26$ & 6 & 0 & $9: 34$ & 11 \\
\hline & 3 & $7 / 5 / 2019$ & $12: 21$ & 7 & 0 & $12: 28$ & 12 \\
\hline & 4 & $7 / 22 / 2019$ & $11: 21$ & 9 & 0 & 12:08 & 15 \\
\hline \multirow[t]{4}{*}{$24 \mathrm{a}$} & 1 & $5 / 24 / 2019$ & $10: 35$ & 7 & 0 & $10: 45$ & 15 \\
\hline & 2 & $6 / 20 / 2019$ & $13: 58$ & 8 & 0 & $14: 06$ & 18 \\
\hline & 3 & 7/8/2019 & $13: 40$ & 6 & 0 & $13: 46$ & 14 \\
\hline & 4 & $7 / 30 / 2019$ & $12: 30$ & 8 & 0 & $12: 38$ & 13 \\
\hline \multirow[t]{4}{*}{$25 \mathrm{a}$} & 1 & $5 / 23 / 2019$ & $12: 35$ & 7 & 0 & $12: 42$ & 9 \\
\hline & 2 & $6 / 18 / 2019$ & $15: 00$ & 6 & 0 & $15: 06$ & 13 \\
\hline & 3 & $7 / 1 / 2019$ & $12: 00$ & 8 & 0 & 12:08 & 12 \\
\hline & 4 & $7 / 26 / 2019$ & 11:03 & 9 & 1 & $11: 12$ & 15 \\
\hline \multirow[t]{4}{*}{$26 a$} & 1 & $5 / 23 / 2019$ & $14: 50$ & 6 & 0 & $14: 56$ & 15 \\
\hline & 2 & $6 / 18 / 2019$ & $14: 30$ & 6 & 0 & $14: 36$ & 14 \\
\hline & 3 & $7 / 1 / 2019$ & $12: 42$ & 8 & 0 & $12: 50$ & 15 \\
\hline & 4 & $7 / 26 / 2019$ & $10: 34$ & 7 & 0 & $10: 41$ & 17 \\
\hline \multirow[t]{4}{*}{$27 \mathrm{a}$} & 1 & $5 / 21 / 2019$ & $8: 59$ & 6 & 0 & $12: 40$ & 13 \\
\hline & 2 & $6 / 18 / 2019$ & $14: 00$ & 5 & 0 & 14:05 & 12 \\
\hline & 3 & $7 / 10 / 2019$ & $9: 34$ & 8 & 0 & $9: 42$ & 14 \\
\hline & 4 & $7 / 30 / 2019$ & 13:04 & 6 & 0 & $13: 10$ & 12 \\
\hline \multirow[t]{4}{*}{$28 \mathrm{a}$} & 1 & $5 / 22 / 2019$ & $10: 50$ & 11 & 0 & 11:01 & 9 \\
\hline & 2 & $6 / 10 / 2019$ & $11: 26$ & 9 & 0 & $11: 35$ & 15 \\
\hline & 3 & $7 / 10 / 2019$ & $10: 21$ & 8 & 0 & $10: 29$ & 15 \\
\hline & 4 & $7 / 30 / 2019$ & $13: 34$ & 7 & 0 & $13: 41$ & 15 \\
\hline \multirow[t]{4}{*}{$29 a$} & 1 & $5 / 23 / 2019$ & $15: 30$ & 8 & 0 & $15: 40$ & 13 \\
\hline & 2 & $6 / 18 / 2019$ & $13: 28$ & 6 & 0 & $13: 34$ & 16 \\
\hline & 3 & 7/1/2019 & $13: 26$ & 8 & 0 & $13: 34$ & 16 \\
\hline & 4 & $7 / 25 / 2019$ & $15: 27$ & 7 & 0 & $15: 34$ & 15 \\
\hline $30 a$ & 1 & $5 / 31 / 2019$ & $9: 11$ & 7 & 0 & $9: 18$ & 12 \\
\hline
\end{tabular}




\begin{tabular}{|c|c|c|c|c|c|c|c|}
\hline & 2 & $6 / 18 / 2019$ & 13:00 & 8 & 0 & 13:08 & 12 \\
\hline & 3 & $7 / 1 / 2019$ & $14: 12$ & 8 & 0 & $14: 20$ & 14 \\
\hline & 4 & $7 / 25 / 2019$ & $16: 03$ & 8 & 0 & $16: 11$ & 14 \\
\hline \multirow[t]{4}{*}{$31 \mathrm{a}$} & 1 & $5 / 21 / 2019$ & $14: 25$ & 9 & 0 & $14: 34$ & 16 \\
\hline & 2 & $6 / 21 / 2019$ & $9: 50$ & 7 & 0 & $9: 57$ & 13 \\
\hline & 3 & $7 / 10 / 2019$ & $12: 49$ & 7 & 0 & $12: 56$ & 16 \\
\hline & 4 & $7 / 29 / 2019$ & $10: 42$ & 6 & 0 & $12: 42$ & 11 \\
\hline \multirow[t]{4}{*}{$32 \mathrm{a}$} & 1 & $5 / 31 / 2019$ & $14: 20$ & 6 & 0 & $14: 26$ & 15 \\
\hline & 2 & $6 / 19 / 2019$ & 9:01 & 9 & 0 & 9:10 & 14 \\
\hline & 3 & 7/8/2019 & $10: 49$ & 9 & 0 & $10: 58$ & 18 \\
\hline & 4 & $7 / 29 / 2019$ & $10: 05$ & 6 & 0 & $10: 11$ & 17 \\
\hline \multirow[t]{4}{*}{$33 a$} & 1 & $5 / 21 / 2019$ & $15: 10$ & 9 & 0 & $15: 19$ & 11 \\
\hline & 2 & $6 / 19 / 2019$ & $9: 36$ & 6 & 0 & $9: 42$ & 14 \\
\hline & 3 & 7/3/2019 & $9: 52$ & 8 & 0 & 10:00 & 12 \\
\hline & 4 & $7 / 25 / 2019$ & $9: 27$ & 8 & 0 & $9: 35$ & 15 \\
\hline \multirow[t]{4}{*}{$34 \mathrm{a}$} & 1 & $5 / 22 / 2019$ & $12: 30$ & 8 & 0 & $12: 38$ & 17 \\
\hline & 2 & $6 / 21 / 2019$ & $10: 18$ & 6 & 0 & $10: 24$ & 16 \\
\hline & 3 & 7/8/2019 & $11: 31$ & 7 & 0 & $11: 38$ & 14 \\
\hline & 4 & $7 / 29 / 2019$ & $10: 34$ & 6 & 0 & $10: 40$ & 16 \\
\hline \multirow[t]{4}{*}{$35 \mathrm{a}$} & 1 & $5 / 21 / 2019$ & $13: 48$ & 7 & 0 & $13: 55$ & 14 \\
\hline & 2 & $6 / 21 / 2019$ & $10: 52$ & 8 & 0 & 11:00 & 15 \\
\hline & 3 & $7 / 5 / 2019$ & $10: 36$ & 7 & 0 & $10: 43$ & 17 \\
\hline & 4 & $7 / 22 / 2019$ & $14: 05$ & 10 & 0 & $11: 11$ & 14 \\
\hline \multirow[t]{4}{*}{$36 a$} & 1 & $5 / 31 / 2019$ & $13: 42$ & 7 & 0 & $13: 49$ & 17 \\
\hline & 2 & $6 / 21 / 2019$ & $11: 30$ & 8 & 0 & $11: 38$ & 14 \\
\hline & 3 & $7 / 10 / 2019$ & $13: 21$ & 8 & 0 & $13: 29$ & 17 \\
\hline & 4 & $7 / 29 / 2019$ & $11: 22$ & 6 & 0 & $11: 28$ & 16 \\
\hline \multirow[t]{4}{*}{$37 \mathrm{a}$} & 1 & $5 / 23 / 2019$ & $8: 35$ & 8 & 0 & $10: 11$ & 12 \\
\hline & 2 & $6 / 21 / 2019$ & $12: 06$ & 8 & 0 & $12: 14$ & 16 \\
\hline & 3 & 7/10/2019 & $14: 06$ & 6 & 0 & $14: 12$ & 14 \\
\hline & 4 & $7 / 29 / 2019$ & $11: 54$ & 6 & 0 & $12: 00$ & 16 \\
\hline \multirow[t]{4}{*}{$38 \mathrm{a}$} & 1 & $5 / 31 / 2019$ & 13:09 & 8 & 0 & $13: 17$ & 13 \\
\hline & 2 & $6 / 21 / 2019$ & 13:02 & 6 & 0 & 13:08 & 16 \\
\hline & 3 & 7/5/2019 & $11: 16$ & 7 & 0 & $11: 23$ & 12 \\
\hline & 4 & $7 / 22 / 2019$ & $13: 36$ & 9 & 0 & $12: 19$ & 13 \\
\hline \multirow[t]{4}{*}{$39 a$} & 1 & $5 / 22 / 2019$ & $13: 20$ & 6 & 0 & $13: 26$ & 12 \\
\hline & 2 & $6 / 10 / 2019$ & $9: 41$ & 6 & 0 & $9: 47$ & 13 \\
\hline & 3 & 7/3/2019 & 9:02 & 10 & 0 & $9: 12$ & 12 \\
\hline & 4 & $7 / 25 / 2019$ & $8: 46$ & 9 & 0 & $10: 33$ & 15 \\
\hline \multirow[t]{2}{*}{$40 \mathrm{a}$} & 1 & $5 / 22 / 2019$ & $13: 52$ & 7 & 0 & $13: 59$ & 13 \\
\hline & 2 & $6 / 21 / 2019$ & $13: 48$ & 9 & 0 & $13: 57$ & 19 \\
\hline
\end{tabular}




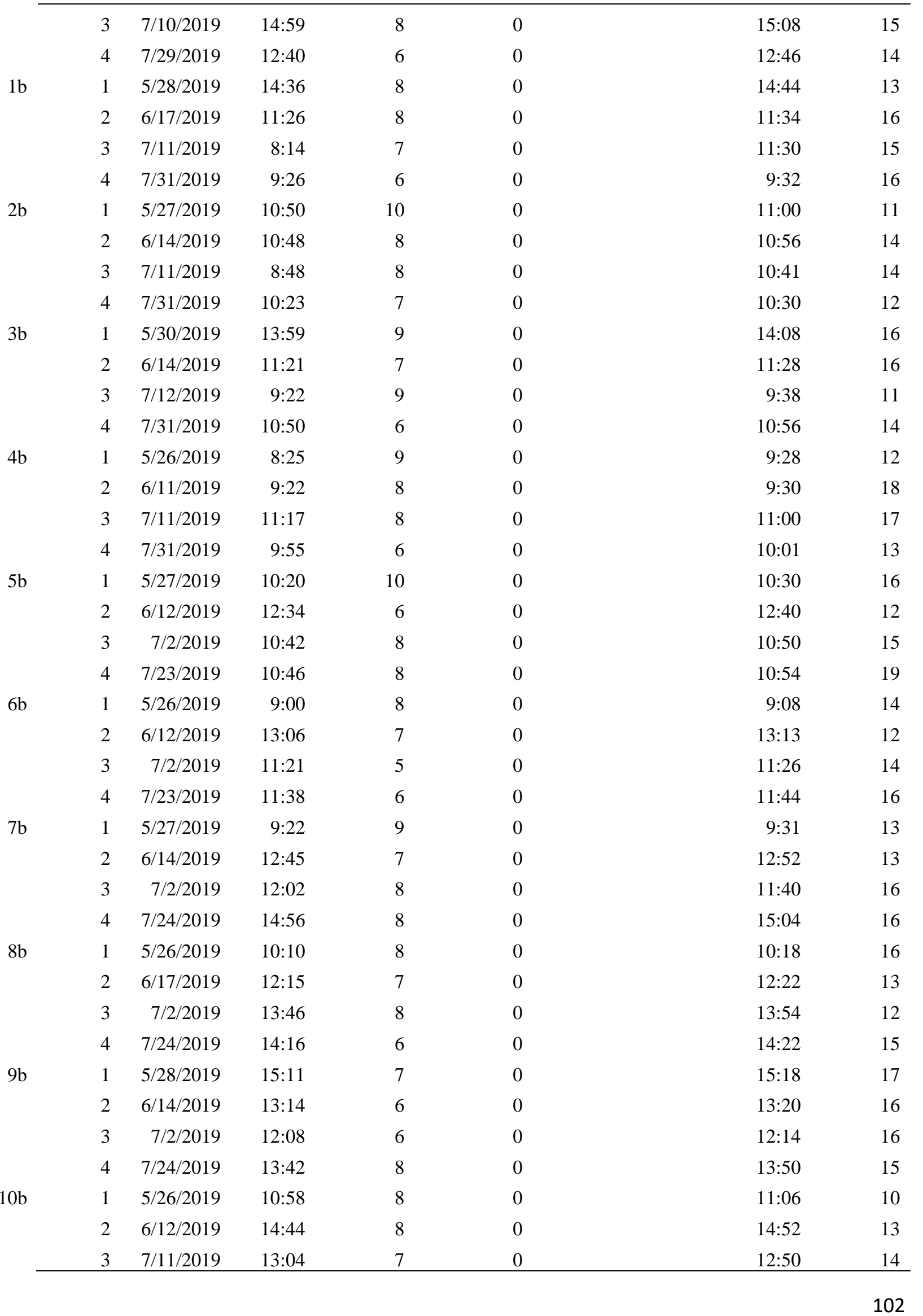




\begin{tabular}{|c|c|c|c|c|c|c|c|}
\hline & 4 & 7/31/2019 & $12: 21$ & 7 & 0 & $12: 28$ & 12 \\
\hline \multirow[t]{4}{*}{$11 b$} & 1 & $5 / 28 / 2019$ & $12: 06$ & 7 & 0 & $12: 13$ & 13 \\
\hline & 2 & $6 / 12 / 2019$ & $14: 02$ & 8 & 0 & $14: 10$ & 18 \\
\hline & 3 & $7 / 11 / 2019$ & $12: 01$ & 8 & 0 & 12:09 & 17 \\
\hline & 4 & $7 / 31 / 2019$ & $12: 46$ & 6 & 0 & $12: 52$ & 12 \\
\hline \multirow[t]{4}{*}{$12 b$} & 1 & $5 / 30 / 2019$ & $13: 21$ & 8 & 0 & $13: 29$ & 17 \\
\hline & 2 & $6 / 14 / 2019$ & $12: 08$ & 12 & 0 & $12: 20$ & 20 \\
\hline & 3 & $7 / 11 / 2019$ & $10: 10$ & 9 & 0 & $10: 19$ & 19 \\
\hline & 4 & $7 / 31 / 2019$ & $11: 16$ & 7 & 0 & $11: 23$ & 14 \\
\hline \multirow[t]{4}{*}{$13 b$} & 1 & $5 / 26 / 2019$ & $11: 52$ & 7 & 0 & $11: 59$ & 14 \\
\hline & 2 & $6 / 12 / 2019$ & $12: 03$ & 7 & 0 & $12: 10$ & 11 \\
\hline & 3 & $7 / 11 / 2019$ & $14: 04$ & 7 & 0 & $14: 11$ & 19 \\
\hline & 4 & $7 / 31 / 2019$ & $11: 45$ & 6 & 0 & $11: 51$ & 14 \\
\hline \multirow[t]{4}{*}{$14 b$} & 1 & $5 / 28 / 2019$ & $11: 41$ & 5 & 0 & $11: 46$ & 11 \\
\hline & 2 & $6 / 14 / 2019$ & $14: 21$ & 8 & 0 & $14: 29$ & 15 \\
\hline & 3 & $7 / 2 / 2019$ & $12: 58$ & 8 & 0 & 13:06 & 14 \\
\hline & 4 & $7 / 24 / 2019$ & $13: 14$ & 6 & 0 & $13: 20$ & 18 \\
\hline \multirow[t]{4}{*}{$17 b$} & 1 & $5 / 30 / 2019$ & $10: 31$ & 6 & 0 & $10: 37$ & 12 \\
\hline & 2 & $6 / 13 / 2019$ & 13:00 & 7 & 0 & 13:07 & 13 \\
\hline & 3 & 7/2/2019 & $9: 58$ & 8 & 0 & $9: 32$ & 14 \\
\hline & 4 & $7 / 23 / 2019$ & $8: 32$ & 7 & 0 & $9: 42$ & 18 \\
\hline \multirow[t]{4}{*}{$18 b$} & 1 & $5 / 26 / 2019$ & $12: 56$ & 8 & 0 & 13:01 & 14 \\
\hline & 2 & $6 / 17 / 2019$ & $8: 52$ & 8 & 0 & 9:00 & 12 \\
\hline & 3 & 7/9/2019 & $10: 38$ & 8 & 0 & $10: 14$ & 24 \\
\hline & 4 & $8 / 1 / 2019$ & $10: 19$ & 6 & 0 & $10: 25$ & 15 \\
\hline \multirow[t]{4}{*}{$19 b$} & 1 & $5 / 26 / 2019$ & $14: 22$ & 8 & 0 & $14: 30$ & 11 \\
\hline & 2 & $6 / 12 / 2019$ & $9: 41$ & 7 & 0 & $9: 48$ & 13 \\
\hline & 3 & $7 / 4 / 2019$ & $9: 24$ & 6 & 0 & $9: 30$ & 12 \\
\hline & 4 & $7 / 23 / 2019$ & $8: 52$ & 8 & 0 & 9:00 & 15 \\
\hline \multirow[t]{4}{*}{$20 b$} & 1 & $5 / 26 / 2019$ & $13: 42$ & 8 & 0 & $13: 50$ & 13 \\
\hline & 2 & $6 / 12 / 2019$ & $10: 26$ & 8 & 0 & $10: 34$ & 14 \\
\hline & 3 & 7/2/2019 & $9: 10$ & 8 & 0 & $9: 18$ & 14 \\
\hline & 4 & $7 / 24 / 2019$ & $12: 02$ & 8 & 0 & $12: 10$ & 21 \\
\hline \multirow[t]{4}{*}{$21 b$} & 1 & $5 / 30 / 2019$ & $9: 59$ & 9 & 0 & $10: 08$ & 14 \\
\hline & 2 & $6 / 12 / 2019$ & 11:04 & 8 & 0 & $11: 12$ & 14 \\
\hline & 3 & $7 / 12 / 2019$ & $11: 31$ & 9 & 0 & $11: 40$ & 16 \\
\hline & 4 & $8 / 1 / 2019$ & $10: 58$ & 7 & 0 & 11:05 & 12 \\
\hline \multirow[t]{4}{*}{$22 b$} & 1 & $5 / 27 / 2019$ & $12: 00$ & 10 & 0 & $12: 10$ & 16 \\
\hline & 2 & $6 / 13 / 2019$ & $11: 52$ & 8 & 0 & $12: 00$ & 15 \\
\hline & 3 & 7/4/2019 & $10: 12$ & 8 & 0 & $10: 20$ & 12 \\
\hline & 4 & $7 / 23 / 2019$ & $13: 10$ & 6 & 0 & $13: 16$ & 14 \\
\hline
\end{tabular}




\begin{tabular}{|c|c|c|c|c|c|c|c|}
\hline \multirow[t]{4}{*}{$23 b$} & 1 & $5 / 27 / 2019$ & $12: 32$ & 7 & 0 & $12: 39$ & 14 \\
\hline & 2 & $6 / 13 / 2019$ & $13: 42$ & 8 & 0 & $13: 50$ & 14 \\
\hline & 3 & 7/4/2019 & $10: 42$ & 8 & 0 & $10: 50$ & 13 \\
\hline & 4 & $7 / 23 / 2019$ & $13: 40$ & 8 & 0 & $13: 48$ & 12 \\
\hline \multirow[t]{4}{*}{$24 b$} & 1 & $5 / 30 / 2019$ & $9: 19$ & 9 & 0 & $9: 28$ & 15 \\
\hline & 2 & $6 / 17 / 2019$ & $9: 48$ & 8 & 0 & $9: 56$ & 14 \\
\hline & 3 & 7/9/2019 & $9: 26$ & 9 & 0 & $9: 35$ & 15 \\
\hline & 4 & $8 / 1 / 2019$ & $9: 24$ & 6 & 0 & $9: 30$ & 9 \\
\hline \multirow[t]{4}{*}{$25 b$} & 1 & $5 / 28 / 2019$ & 9:59 & 7 & 0 & $10: 06$ & 14 \\
\hline & 2 & $6 / 17 / 2019$ & $9: 20$ & 6 & 0 & $9: 26$ & 14 \\
\hline & 3 & 7/9/2019 & $8: 16$ & 10 & 0 & $10: 00$ & 14 \\
\hline & 4 & $8 / 1 / 2019$ & $8: 58$ & 8 & 0 & 9:06 & 12 \\
\hline \multirow[t]{4}{*}{$26 b$} & 1 & $5 / 28 / 2019$ & 9:01 & 7 & 0 & 9:08 & 12 \\
\hline & 2 & $6 / 14 / 2019$ & $9: 53$ & 7 & 0 & 10:00 & 13 \\
\hline & 3 & $7 / 12 / 2019$ & $10: 46$ & 8 & 0 & $10: 54$ & 19 \\
\hline & 4 & $8 / 1 / 2019$ & $11: 26$ & 6 & 0 & $11: 32$ & 12 \\
\hline \multirow[t]{4}{*}{$27 b$} & 1 & $5 / 29 / 2019$ & $13: 46$ & 13 & 0 & $14: 00$ & 16 \\
\hline & 2 & $6 / 11 / 2019$ & $10: 41$ & 7 & 0 & $10: 48$ & 11 \\
\hline & 3 & $7 / 12 / 2019$ & $8: 48$ & 8 & 0 & 10:01 & 15 \\
\hline & 4 & $8 / 2 / 2019$ & $10: 15$ & 9 & 0 & $10: 00$ & 16 \\
\hline \multirow[t]{4}{*}{$28 b$} & 1 & $5 / 28 / 2019$ & 10:56 & 8 & 0 & 11:04 & 16 \\
\hline & 2 & $6 / 17 / 2019$ & $12: 50$ & 9 & 0 & $12: 59$ & 13 \\
\hline & 3 & $7 / 11 / 2019$ & $15: 30$ & 10 & 0 & $15: 40$ & 15 \\
\hline & 4 & $7 / 31 / 2019$ & $13: 24$ & 6 & 0 & $13: 30$ & 16 \\
\hline \multirow[t]{4}{*}{$29 b$} & 1 & $5 / 27 / 2019$ & $8: 52$ & 8 & 0 & 9:00 & 11 \\
\hline & 2 & $6 / 17 / 2019$ & $13: 26$ & 8 & 0 & $13: 34$ & 16 \\
\hline & 3 & $7 / 11 / 2019$ & $16: 02$ & 9 & 0 & $16: 11$ & 22 \\
\hline & 4 & $7 / 31 / 2019$ & 14:01 & 5 & 0 & $14: 06$ & 14 \\
\hline \multirow[t]{4}{*}{$30 \mathrm{~b}$} & 1 & $5 / 28 / 2019$ & $9: 31$ & 6 & 0 & $9: 37$ & 13 \\
\hline & 2 & $6 / 14 / 2019$ & $9: 10$ & 9 & 0 & $9: 19$ & 14 \\
\hline & 3 & 7/9/2019 & $8: 48$ & 6 & 0 & $8: 54$ & 18 \\
\hline & 4 & $8 / 1 / 2019$ & $9: 48$ & 6 & 0 & $9: 54$ & 14 \\
\hline \multirow[t]{4}{*}{$31 \mathrm{~b}$} & 1 & $5 / 29 / 2019$ & $13: 12$ & 8 & 0 & $13: 20$ & 14 \\
\hline & 2 & $6 / 11 / 2019$ & 11:08 & 6 & 0 & $11: 14$ & 10 \\
\hline & 3 & $7 / 12 / 2019$ & $9: 32$ & 8 & 0 & $9: 40$ & 15 \\
\hline & 4 & $8 / 2 / 2019$ & $9: 52$ & 8 & 0 & $10: 00$ & 15 \\
\hline \multirow[t]{4}{*}{$32 b$} & 1 & $5 / 27 / 2019$ & 13:00 & 12 & 0 & $13: 12$ & 13 \\
\hline & 2 & $6 / 11 / 2019$ & $11: 35$ & 9 & 0 & $11: 44$ & 16 \\
\hline & 3 & 7/4/2019 & 12:06 & 6 & 0 & $11: 26$ & 14 \\
\hline & 4 & $7 / 23 / 2019$ & $14: 21$ & 5 & 0 & $14: 26$ & 14 \\
\hline $33 \mathrm{~b}$ & 1 & $5 / 29 / 2019$ & 12:08 & 8 & 0 & $12: 16$ & 15 \\
\hline
\end{tabular}




\begin{tabular}{|c|c|c|c|c|c|c|c|c|c|}
\hline & 2 & $6 / 11 / 2019$ & $12: 08$ & 8 & 0 & & & $12: 16$ & 14 \\
\hline & 3 & 7/9/2019 & $15: 56$ & 8 & 0 & & & 16:04 & 16 \\
\hline & 4 & $8 / 2 / 2019$ & $9: 22$ & 7 & 0 & & & $9: 29$ & 13 \\
\hline \multirow[t]{4}{*}{$34 b$} & 1 & $5 / 29 / 2019$ & $11: 26$ & 9 & 0 & & & $11: 35$ & 14 \\
\hline & 2 & $6 / 17 / 2019$ & $10: 39$ & 9 & 0 & & & $10: 48$ & 12 \\
\hline & 3 & 7/9/2019 & $15: 21$ & 8 & 0 & & & $15: 29$ & 17 \\
\hline & 4 & $8 / 2 / 2019$ & $8: 53$ & 7 & 0 & & & $9: 00$ & 12 \\
\hline \multirow[t]{4}{*}{$35 b$} & 1 & $5 / 29 / 2019$ & $10: 48$ & 12 & 0 & & & $11: 00$ & 13 \\
\hline & 2 & $6 / 11 / 2019$ & $13: 41$ & 8 & 0 & & & $13: 49$ & 15 \\
\hline & 3 & 7/4/2019 & $12: 06$ & 6 & 0 & & & $12: 12$ & 18 \\
\hline & 4 & $7 / 23 / 2019$ & $14: 53$ & 7 & 0 & & & $15: 00$ & 16 \\
\hline \multirow[t]{4}{*}{$36 b$} & 1 & $5 / 30 / 2019$ & $12: 31$ & 8 & 0 & & & $12: 39$ & 10 \\
\hline & 2 & $6 / 13 / 2019$ & $11: 13$ & 7 & 0 & & & $11: 20$ & 16 \\
\hline & 3 & 7/9/2019 & $14: 26$ & 8 & 0 & & & $14: 34$ & 16 \\
\hline & 4 & $8 / 1 / 2019$ & $14: 10$ & 7 & 0 & & & $14: 17$ & 15 \\
\hline \multirow[t]{4}{*}{$37 b$} & 1 & $5 / 30 / 2019$ & $11: 52$ & 7 & 0 & & & $11: 59$ & 15 \\
\hline & 2 & $6 / 13 / 2019$ & $10: 36$ & 7 & 0 & & & $10: 43$ & 12 \\
\hline & 3 & $7 / 4 / 2019$ & $12: 49$ & 7 & 0 & & & $12: 56$ & 12 \\
\hline & 4 & $7 / 24 / 2019$ & $9: 32$ & 6 & 0 & & & $9: 38$ & 14 \\
\hline \multirow[t]{4}{*}{$38 b$} & 1 & $5 / 29 / 2019$ & $10: 16$ & 7 & 0 & & & $10: 23$ & 13 \\
\hline & 2 & $6 / 11 / 2019$ & $12: 34$ & 6 & 1 & & & $12: 40$ & 12 \\
\hline & 3 & $7 / 4 / 2019$ & $13: 21$ & 8 & 0 & & & $13: 29$ & 12 \\
\hline & 4 & $7 / 24 / 2019$ & $10: 24$ & 8 & 1 & & & $10: 32$ & 14 \\
\hline \multirow[t]{4}{*}{$39 b$} & 1 & $5 / 27 / 2019$ & $13: 40$ & 9 & 0 & & & $13: 49$ & 16 \\
\hline & 2 & $6 / 11 / 2019$ & 13:02 & 6 & 0 & & & 13:08 & 12 \\
\hline & 3 & 7/9/2019 & $13: 41$ & 8 & 0 & & & $13: 49$ & 19 \\
\hline & 4 & $8 / 1 / 2019$ & $13: 40$ & 5 & 0 & & & $13: 45$ & 15 \\
\hline \multirow[t]{4}{*}{$40 \mathrm{~b}$} & 1 & $5 / 30 / 2019$ & $11: 20$ & 6 & 0 & & & $11: 26$ & 14 \\
\hline & 2 & $6 / 13 / 2019$ & $9: 34$ & 6 & 0 & & & $9: 40$ & 12 \\
\hline & 3 & 7/9/2019 & $13: 00$ & 7 & 0 & & & 13:07 & 15 \\
\hline & 4 & $8 / 1 / 2019$ & 13:07 & 6 & 0 & & & $13: 13$ & 13 \\
\hline \multirow[t]{4}{*}{$41 b$} & 1 & $5 / 29 / 2019$ & $9: 21$ & 7 & 0 & & & $9: 28$ & 12 \\
\hline & 2 & $6 / 13 / 2019$ & 9:02 & 8 & 0 & & & $9: 10$ & 12 \\
\hline & 3 & 7/9/2019 & $12: 21$ & 8 & 0 & & & $12: 29$ & 15 \\
\hline & 4 & $8 / 1 / 2019$ & $12: 36$ & 6 & 0 & & & $12: 42$ & 14 \\
\hline \multirow[t]{4}{*}{$42 b$} & 1 & $5 / 29 / 2019$ & $9: 51$ & 7 & 0 & & & $9: 58$ & 12 \\
\hline & 2 & $6 / 13 / 2019$ & 10:04 & 6 & 0 & & & $10: 10$ & 13 \\
\hline & 3 & 7/4/2019 & 14:09 & 8 & 0 & & & $14: 17$ & 13 \\
\hline & 4 & $7 / 24 / 2019$ & $8: 39$ & 6 & 0 & & & $11: 00$ & 9 \\
\hline \multirow[t]{2}{*}{$1 \mathrm{a}$} & 1 & $5 / 22 / 2020$ & $9: 15$ & 6 & 0 & $9: 23$ & 7 & $9: 31$ & 6 \\
\hline & 2 & $6 / 11 / 2020$ & $8: 54$ & 7 & 0 & $9: 02$ & 8 & $9: 10$ & 6 \\
\hline
\end{tabular}




\begin{tabular}{|c|c|c|c|c|c|c|c|c|c|}
\hline & 3 & $7 / 13 / 2020$ & $8: 46$ & 6 & 0 & $8: 54$ & 6 & 9:02 & 6 \\
\hline & 4 & $7 / 29 / 2020$ & $11: 21$ & 8 & 0 & $11: 29$ & 5 & $11: 34$ & 6 \\
\hline \multirow[t]{4}{*}{$2 \mathrm{a}$} & 1 & $5 / 18 / 2020$ & $11: 50$ & 10 & 0 & $12: 02$ & 10 & $12: 15$ & 6 \\
\hline & 2 & $6 / 11 / 2020$ & $9: 24$ & 6 & 0 & $9: 32$ & 5 & $9: 38$ & 5 \\
\hline & 3 & $7 / 13 / 2020$ & $9: 16$ & 5 & 0 & $9: 21$ & 5 & $9: 26$ & 5 \\
\hline & 4 & $7 / 29 / 2020$ & $11: 55$ & 5 & 0 & $12: 00$ & 5 & $12: 05$ & 7 \\
\hline \multirow[t]{4}{*}{$3 a$} & 1 & $5 / 22 / 2020$ & $8: 39$ & 7 & 0 & $8: 47$ & 7 & 9:01 & 9 \\
\hline & 2 & $6 / 11 / 2020$ & $9: 50$ & 5 & 0 & $9: 55$ & 5 & $10: 00$ & 6 \\
\hline & 3 & $7 / 13 / 2020$ & $9: 38$ & 6 & 0 & $9: 44$ & 6 & $9: 51$ & 7 \\
\hline & 4 & $7 / 24 / 2020$ & $12: 21$ & 7 & 0 & $12: 28$ & 5 & $12: 33$ & 7 \\
\hline \multirow[t]{4}{*}{$4 a$} & 1 & $5 / 24 / 2020$ & 14:09 & 9 & 0 & $14: 19$ & 7 & $14: 28$ & 7 \\
\hline & 2 & $6 / 9 / 2020$ & $14: 21$ & 8 & 0 & $14: 30$ & 6 & $14: 40$ & 9 \\
\hline & 3 & $7 / 12 / 2020$ & $9: 47$ & 6 & 0 & 9:53 & 7 & $10: 00$ & 8 \\
\hline & 4 & $7 / 31 / 2020$ & $15: 21$ & 4 & 0 & $15: 25$ & 5 & $15: 30$ & 5 \\
\hline \multirow[t]{4}{*}{$5 a$} & 1 & $5 / 22 / 2020$ & $14: 12$ & 5 & 0 & $14: 18$ & 8 & $14: 28$ & 8 \\
\hline & 2 & $6 / 13 / 2020$ & $12: 54$ & 6 & 0 & $13: 00$ & 6 & 13:07 & 7 \\
\hline & 3 & $7 / 12 / 2020$ & $9: 13$ & 5 & 0 & $9: 18$ & 5 & $9: 23$ & 6 \\
\hline & 4 & $7 / 31 / 2020$ & $15: 48$ & 4 & 0 & $15: 52$ & 6 & $15: 59$ & 6 \\
\hline \multirow[t]{4}{*}{$6 a$} & 1 & $5 / 20 / 2020$ & $13: 20$ & 7 & 0 & $13: 29$ & 8 & $13: 38$ & 11 \\
\hline & 2 & $6 / 8 / 2020$ & $13: 42$ & 6 & 0 & $13: 49$ & 7 & $13: 58$ & 10 \\
\hline & 3 & $7 / 12 / 2020$ & $8: 50$ & 6 & 0 & $8: 56$ & 5 & 9:01 & 6 \\
\hline & 4 & $7 / 29 / 2020$ & $15: 42$ & 5 & 0 & $15: 47$ & 4 & $15: 47$ & 4 \\
\hline \multirow[t]{4}{*}{$7 \mathrm{a}$} & 1 & $5 / 20 / 2020$ & $8: 29$ & 7 & 0 & $8: 37$ & 7 & 13:04 & 7 \\
\hline & 2 & $6 / 9 / 2020$ & $8: 50$ & 5 & 0 & $8: 55$ & 5 & 9:00 & 8 \\
\hline & 3 & $7 / 12 / 2020$ & $10: 23$ & 7 & 0 & $10: 30$ & 5 & $10: 35$ & 5 \\
\hline & 4 & $7 / 31 / 2020$ & $8: 54$ & 5 & 0 & 9:00 & 6 & 9:06 & 5 \\
\hline \multirow[t]{4}{*}{$8 a$} & 1 & $5 / 22 / 2020$ & $13: 30$ & 5 & 0 & $13: 37$ & 6 & $13: 44$ & 6 \\
\hline & 2 & $6 / 13 / 2020$ & $12: 16$ & 7 & 0 & $12: 23$ & 7 & $12: 32$ & 8 \\
\hline & 3 & $7 / 9 / 2020$ & $8: 52$ & 5 & 0 & $8: 57$ & 6 & 9:03 & 7 \\
\hline & 4 & $7 / 31 / 2020$ & $14: 29$ & 7 & 0 & $14: 36$ & 6 & $14: 42$ & 8 \\
\hline \multirow[t]{4}{*}{$9 \mathrm{a}$} & 1 & $5 / 24 / 2020$ & $8: 42$ & 8 & 0 & $8: 52$ & 7 & 9:01 & 6 \\
\hline & 2 & $6 / 13 / 2020$ & $11: 44$ & 6 & 0 & $11: 51$ & 7 & $12: 00$ & 7 \\
\hline & 3 & $7 / 9 / 2020$ & $9: 16$ & 5 & 0 & $9: 21$ & 5 & $9: 26$ & 5 \\
\hline & 4 & $7 / 31 / 2020$ & $9: 20$ & 5 & 0 & $9: 25$ & 5 & $9: 30$ & 6 \\
\hline \multirow[t]{4}{*}{$10 \mathrm{a}$} & 1 & $5 / 22 / 2020$ & $12: 58$ & 6 & 0 & $13: 05$ & 5 & $13: 10$ & 6 \\
\hline & 2 & $6 / 9 / 2020$ & $9: 11$ & 5 & 0 & $9: 16$ & 5 & $9: 22$ & 6 \\
\hline & 3 & $7 / 9 / 2020$ & $9: 36$ & 4 & 0 & $9: 40$ & 4 & $9: 44$ & 6 \\
\hline & 4 & $7 / 31 / 2020$ & $9: 45$ & 5 & 0 & $9: 50$ & 5 & $9: 55$ & 5 \\
\hline \multirow[t]{3}{*}{$11 \mathrm{a}$} & 1 & $5 / 18 / 2020$ & $8: 12$ & 12 & 0 & $8: 24$ & 12 & $10: 39$ & 7 \\
\hline & 2 & $6 / 13 / 2020$ & $11: 13$ & 7 & 0 & $11: 20$ & 6 & $11: 27$ & 8 \\
\hline & 3 & $7 / 12 / 2020$ & $10: 49$ & 5 & 0 & $10: 54$ & 6 & $11: 00$ & 6 \\
\hline
\end{tabular}




\begin{tabular}{|c|c|c|c|c|c|c|c|c|c|}
\hline & 4 & $7 / 27 / 2020$ & $9: 16$ & 9 & 0 & $9: 25$ & 7 & $9: 32$ & 8 \\
\hline \multirow[t]{4}{*}{$12 \mathrm{a}$} & 1 & $5 / 20 / 2020$ & 9:02 & 10 & 0 & $9: 13$ & 7 & $9: 21$ & 7 \\
\hline & 2 & $6 / 8 / 2020$ & $8: 47$ & 7 & 0 & 8:56 & 8 & 9:04 & 6 \\
\hline & 3 & $7 / 12 / 2020$ & $11: 11$ & 4 & 0 & $11: 15$ & 5 & $11: 20$ & 6 \\
\hline & 4 & $7 / 31 / 2020$ & 10:09 & 5 & 0 & 10:14 & 6 & $10: 20$ & 5 \\
\hline \multirow[t]{4}{*}{$13 a$} & 1 & $5 / 24 / 2020$ & $9: 12$ & 5 & 0 & $9: 17$ & 6 & $9: 24$ & 6 \\
\hline & 2 & $6 / 8 / 2020$ & $9: 20$ & 6 & 0 & $9: 26$ & 7 & $9: 34$ & 6 \\
\hline & 3 & $7 / 9 / 2020$ & $9: 58$ & 6 & 0 & 10:04 & 5 & 10:09 & 4 \\
\hline & 4 & $7 / 27 / 2020$ & $9: 55$ & 8 & 0 & 10:03 & 7 & $10: 10$ & 6 \\
\hline \multirow[t]{4}{*}{$14 \mathrm{a}$} & 1 & $5 / 24 / 2020$ & $9: 36$ & 7 & 0 & $9: 44$ & 6 & 9:51 & 7 \\
\hline & 2 & $6 / 8 / 2020$ & $9: 50$ & 5 & 0 & $9: 55$ & 7 & 10:03 & 7 \\
\hline & 3 & $7 / 9 / 2020$ & $10: 22$ & 5 & 0 & 10:27 & 4 & 10:31 & 4 \\
\hline & 4 & $7 / 31 / 2020$ & $10: 40$ & 5 & 0 & 10:45 & 6 & $10: 51$ & 5 \\
\hline \multirow[t]{4}{*}{$15 \mathrm{a}$} & 1 & $5 / 24 / 2020$ & 10:06 & 6 & 0 & 10:14 & 6 & $10: 21$ & 5 \\
\hline & 2 & $6 / 8 / 2020$ & $10: 19$ & 6 & 0 & $10: 25$ & 6 & $10: 31$ & 6 \\
\hline & 3 & $7 / 12 / 2020$ & $11: 33$ & 6 & 0 & $11: 40$ & 5 & $11: 45$ & 5 \\
\hline & 4 & $7 / 27 / 2020$ & $10: 24$ & 7 & 0 & 10:31 & 7 & $10: 38$ & 7 \\
\hline \multirow[t]{4}{*}{$16 a$} & 1 & $5 / 20 / 2020$ & $9: 30$ & 7 & 0 & $9: 38$ & 6 & $9: 45$ & 9 \\
\hline & 2 & $6 / 13 / 2020$ & $10: 36$ & 6 & 0 & 10:42 & 7 & $10: 50$ & 6 \\
\hline & 3 & $7 / 12 / 2020$ & $12: 00$ & 6 & 0 & 12:06 & 5 & $12: 11$ & 5 \\
\hline & 4 & $7 / 27 / 2020$ & $10: 54$ & 6 & 0 & 11:00 & 7 & 11:07 & 7 \\
\hline \multirow[t]{4}{*}{$17 \mathrm{a}$} & 1 & $5 / 18 / 2020$ & $8: 46$ & 8 & 0 & $8: 54$ & 8 & $10: 31$ & 8 \\
\hline & 2 & $6 / 10 / 2020$ & $10: 46$ & 4 & 0 & $10: 51$ & 6 & $10: 57$ & 7 \\
\hline & 3 & $7 / 9 / 2020$ & $10: 46$ & 6 & 0 & 10:52 & 5 & $10: 57$ & 5 \\
\hline & 4 & $7 / 27 / 2020$ & $11: 21$ & 6 & 0 & $11: 27$ & 7 & $11: 34$ & 6 \\
\hline \multirow[t]{4}{*}{$18 \mathrm{a}$} & 1 & $5 / 18 / 2020$ & $9: 59$ & 9 & 0 & 10:09 & 7 & 10:19 & 8 \\
\hline & 2 & $6 / 10 / 2020$ & $11: 10$ & 6 & 0 & 11:16 & 7 & $11: 23$ & 7 \\
\hline & 3 & $7 / 9 / 2020$ & $11: 10$ & 4 & 0 & 11:14 & 5 & 11:19 & 5 \\
\hline & 4 & $7 / 31 / 2020$ & 11:08 & 6 & 0 & $11: 14$ & 5 & $11: 19$ & 5 \\
\hline \multirow[t]{4}{*}{$19 a$} & 1 & $5 / 18 / 2020$ & $9: 10$ & 10 & 0 & $9: 22$ & 8 & $9: 37$ & 8 \\
\hline & 2 & $6 / 10 / 2020$ & $11: 50$ & 6 & 0 & 11:56 & 6 & $12: 03$ & 7 \\
\hline & 3 & $7 / 12 / 2020$ & $12: 24$ & 5 & 0 & $12: 29$ & 6 & $12: 35$ & 5 \\
\hline & 4 & $7 / 27 / 2020$ & $11: 55$ & 7 & 0 & 12:02 & 8 & $12: 10$ & 8 \\
\hline \multirow[t]{4}{*}{$20 \mathrm{a}$} & 1 & $5 / 24 / 2020$ & $10: 41$ & 6 & 0 & 10:47 & 5 & $10: 52$ & 8 \\
\hline & 2 & $6 / 9 / 2020$ & $9: 37$ & 6 & 0 & $9: 43$ & 7 & $9: 50$ & 8 \\
\hline & 3 & $7 / 12 / 2020$ & $12: 52$ & 5 & 0 & $12: 57$ & 4 & 13:01 & 5 \\
\hline & 4 & $7 / 31 / 2020$ & $11: 32$ & 6 & 0 & $11: 38$ & 5 & $11: 43$ & 7 \\
\hline \multirow[t]{4}{*}{$21 \mathrm{a}$} & 1 & $5 / 20 / 2020$ & $10: 00$ & 6 & 0 & 10:07 & 5 & $10: 13$ & 7 \\
\hline & 2 & $6 / 9 / 2020$ & $10: 08$ & 6 & 0 & 10:14 & 6 & $10: 21$ & 9 \\
\hline & 3 & $7 / 12 / 2020$ & $13: 15$ & 6 & 0 & $13: 21$ & 5 & $13: 26$ & 6 \\
\hline & 4 & $7 / 31 / 2020$ & $11: 58$ & 5 & 0 & 12:03 & 7 & $12: 10$ & 5 \\
\hline
\end{tabular}




\begin{tabular}{|c|c|c|c|c|c|c|c|c|c|}
\hline \multirow[t]{4}{*}{$22 \mathrm{a}$} & 1 & $5 / 24 / 2020$ & 11:06 & 5 & 0 & $11: 12$ & 7 & 11:20 & 6 \\
\hline & 2 & $6 / 13 / 2020$ & $9: 21$ & 7 & 0 & $9: 29$ & 8 & $9: 39$ & 7 \\
\hline & 3 & $7 / 9 / 2020$ & $11: 38$ & 5 & 0 & $11: 43$ & 6 & $11: 50$ & 6 \\
\hline & 4 & $7 / 31 / 2020$ & $12: 32$ & 4 & 0 & $12: 36$ & 7 & $12: 43$ & 7 \\
\hline \multirow[t]{4}{*}{$23 a$} & 1 & $5 / 24 / 2020$ & $11: 35$ & 7 & 0 & $11: 43$ & 5 & $11: 48$ & 6 \\
\hline & 2 & $6 / 13 / 2020$ & 9:56 & 6 & 0 & 10:06 & 5 & $10: 12$ & 8 \\
\hline & 3 & $7 / 9 / 2020$ & $12: 07$ & 6 & 0 & $12: 13$ & 5 & $12: 18$ & 5 \\
\hline & 4 & $7 / 31 / 2020$ & $13: 21$ & 8 & 0 & $13: 29$ & 5 & $13: 34$ & 6 \\
\hline \multirow[t]{4}{*}{$24 a$} & 1 & $5 / 24 / 2020$ & $13: 21$ & 7 & 0 & $13: 30$ & 6 & $13: 37$ & 6 \\
\hline & 2 & $6 / 8 / 2020$ & $12: 20$ & 8 & 0 & $12: 28$ & 8 & $12: 36$ & 6 \\
\hline & 3 & $7 / 12 / 2020$ & $13: 43$ & 7 & 0 & $13: 50$ & 5 & $13: 55$ & 8 \\
\hline & 4 & $7 / 27 / 2020$ & $12: 29$ & 7 & 0 & $12: 36$ & 6 & $12: 42$ & 5 \\
\hline \multirow[t]{4}{*}{$25 \mathrm{a}$} & 1 & $5 / 24 / 2020$ & $12: 39$ & 5 & 0 & $12: 45$ & 8 & $12: 55$ & 8 \\
\hline & 2 & $6 / 8 / 2020$ & $12: 41$ & 7 & 0 & $12: 49$ & 8 & $12: 58$ & 7 \\
\hline & 3 & $7 / 9 / 2020$ & $12: 49$ & 6 & 1 & $12: 56$ & 6 & 13:02 & 5 \\
\hline & 4 & $7 / 27 / 2020$ & $12: 59$ & 9 & 0 & 13:08 & 6 & $13: 14$ & 6 \\
\hline \multirow[t]{4}{*}{$26 a$} & 1 & $5 / 20 / 2020$ & $12: 45$ & 8 & 0 & $12: 54$ & 8 & 13:05 & 7 \\
\hline & 2 & $6 / 9 / 2020$ & $10: 45$ & 8 & 0 & $10: 55$ & 8 & 11:03 & 7 \\
\hline & 3 & $7 / 12 / 2020$ & $14: 24$ & 7 & 0 & $14: 31$ & 7 & $14: 38$ & 5 \\
\hline & 4 & $7 / 27 / 2020$ & $13: 29$ & 5 & 0 & $13: 34$ & 6 & $13: 41$ & 6 \\
\hline \multirow[t]{4}{*}{$27 \mathrm{a}$} & 1 & $5 / 20 / 2020$ & $10: 56$ & 8 & 0 & 11:05 & 6 & $11: 12$ & 8 \\
\hline & 2 & $6 / 9 / 2020$ & $11: 31$ & 8 & 0 & $11: 40$ & 6 & $11: 46$ & 7 \\
\hline & 3 & $7 / 12 / 2020$ & $14: 59$ & 10 & 0 & 15:09 & 7 & $15: 16$ & 5 \\
\hline & 4 & $7 / 27 / 2020$ & $13: 56$ & 6 & 0 & $14: 02$ & 8 & $14: 10$ & 6 \\
\hline \multirow[t]{4}{*}{$28 \mathrm{a}$} & 1 & $5 / 20 / 2020$ & $11: 21$ & 8 & 0 & $11: 30$ & 5 & $11: 36$ & 8 \\
\hline & 2 & $6 / 9 / 2020$ & 12:09 & 7 & 0 & $12: 18$ & 7 & $12: 25$ & 8 \\
\hline & 3 & 7/9/2020 & $13: 17$ & 7 & 0 & $13: 24$ & 6 & $13: 31$ & 5 \\
\hline & 4 & $7 / 27 / 2020$ & $14: 24$ & 8 & 0 & $14: 32$ & 5 & $14: 37$ & 6 \\
\hline \multirow[t]{4}{*}{$29 a$} & 1 & $5 / 20 / 2020$ & $11: 50$ & 6 & 0 & $11: 57$ & 7 & $12: 06$ & 5 \\
\hline & 2 & $6 / 9 / 2020$ & $12: 46$ & 6 & 0 & $12: 54$ & 6 & 13:00 & 7 \\
\hline & 3 & $7 / 9 / 2020$ & $13: 47$ & 5 & 0 & $13: 52$ & 7 & $14: 01$ & 6 \\
\hline & 4 & $7 / 27 / 2020$ & $14: 59$ & 8 & 0 & 15:07 & 6 & $15: 13$ & 8 \\
\hline \multirow[t]{4}{*}{$30 a$} & 1 & $5 / 20 / 2020$ & $12: 17$ & 7 & 0 & $12: 24$ & 6 & $12: 31$ & 5 \\
\hline & 2 & $6 / 9 / 2020$ & $13: 20$ & 6 & 0 & $13: 28$ & 7 & $13: 35$ & 7 \\
\hline & 3 & $7 / 9 / 2020$ & $14: 19$ & 7 & 0 & $14: 27$ & 9 & $14: 37$ & 6 \\
\hline & 4 & $7 / 31 / 2020$ & $13: 59$ & 6 & 0 & 14:05 & 5 & $14: 10$ & 6 \\
\hline \multirow[t]{4}{*}{$31 \mathrm{a}$} & 1 & $5 / 18 / 2020$ & $12: 56$ & 8 & 0 & 13:06 & 8 & $13: 14$ & 6 \\
\hline & 2 & $6 / 11 / 2020$ & 11:06 & 5 & 0 & $11: 12$ & 7 & $11: 20$ & 5 \\
\hline & 3 & $7 / 13 / 2020$ & 11:00 & 6 & 0 & 11:06 & 6 & $11: 12$ & 7 \\
\hline & 4 & $7 / 29 / 2020$ & $13: 46$ & 5 & 0 & $13: 51$ & 7 & $14: 00$ & 7 \\
\hline $32 a$ & 1 & $5 / 18 / 2020$ & $12: 24$ & 8 & 0 & $12: 33$ & 8 & $12: 42$ & 6 \\
\hline
\end{tabular}




\begin{tabular}{|c|c|c|c|c|c|c|c|c|c|}
\hline & 2 & $6 / 11 / 2020$ & $10: 40$ & 5 & 0 & $10: 45$ & 5 & $10: 51$ & 6 \\
\hline & 3 & $7 / 13 / 2020$ & $10: 32$ & 5 & 0 & $10: 37$ & 5 & $10: 42$ & 6 \\
\hline & 4 & $7 / 29 / 2020$ & $13: 19$ & 5 & 0 & $13: 24$ & 5 & $13: 29$ & 5 \\
\hline \multirow[t]{4}{*}{$33 a$} & 1 & $5 / 22 / 2020$ & $9: 45$ & 8 & 0 & $9: 53$ & 7 & 10:00 & 5 \\
\hline & 2 & $6 / 11 / 2020$ & $10: 16$ & 4 & 0 & $10: 21$ & 5 & $10: 26$ & 5 \\
\hline & 3 & $7 / 13 / 2020$ & $10: 07$ & 5 & 0 & $10: 12$ & 6 & $10: 18$ & 6 \\
\hline & 4 & $7 / 29 / 2020$ & $12: 58$ & 6 & 0 & 13:04 & 6 & $13: 10$ & 5 \\
\hline \multirow[t]{4}{*}{$34 a$} & 1 & $5 / 22 / 2020$ & $10: 10$ & 5 & 0 & $10: 16$ & 4 & $10: 20$ & 4 \\
\hline & 2 & $6 / 11 / 2020$ & $11: 40$ & 6 & 0 & $11: 46$ & 5 & 11:51 & 6 \\
\hline & 3 & $7 / 13 / 2020$ & $11: 33$ & 7 & 0 & $11: 40$ & 5 & $11: 45$ & 5 \\
\hline & 4 & $7 / 29 / 2020$ & $14: 18$ & 5 & 0 & $14: 23$ & 7 & $14: 30$ & 5 \\
\hline \multirow[t]{4}{*}{$35 a$} & 1 & $5 / 18 / 2020$ & $13: 20$ & 9 & 0 & $13: 30$ & 10 & $13: 42$ & 6 \\
\hline & 2 & $6 / 11 / 2020$ & $12: 09$ & 8 & 0 & $12: 17$ & 5 & $12: 23$ & 7 \\
\hline & 3 & $7 / 13 / 2020$ & $12: 01$ & 7 & 0 & 12:08 & 5 & $12: 13$ & 5 \\
\hline & 4 & $7 / 29 / 2020$ & $14: 44$ & 6 & 0 & $14: 50$ & 5 & $14: 55$ & 6 \\
\hline \multirow[t]{4}{*}{$36 a$} & 1 & $5 / 22 / 2020$ & $10: 36$ & 6 & 0 & $10: 43$ & 7 & $10: 51$ & 6 \\
\hline & 2 & $6 / 11 / 2020$ & $12: 49$ & 7 & 0 & $12: 56$ & 9 & 13:06 & 5 \\
\hline & 3 & $7 / 13 / 2020$ & $12: 29$ & 6 & 0 & $12: 35$ & 5 & $12: 42$ & 5 \\
\hline & 4 & $7 / 29 / 2020$ & $10: 34$ & 6 & 0 & $10: 40$ & 5 & $10: 45$ & 6 \\
\hline \multirow[t]{4}{*}{$37 a$} & 1 & $5 / 22 / 2020$ & $11: 15$ & 6 & 0 & $11: 22$ & 7 & $11: 29$ & 6 \\
\hline & 2 & $6 / 11 / 2020$ & $13: 12$ & 7 & 0 & $13: 21$ & 5 & $13: 27$ & 5 \\
\hline & 3 & $7 / 13 / 2020$ & 13:06 & 6 & 0 & $13: 12$ & 7 & $13: 20$ & 6 \\
\hline & 4 & $7 / 29 / 2020$ & $10: 04$ & 6 & 0 & $10: 10$ & 6 & $10: 16$ & 8 \\
\hline \multirow[t]{4}{*}{$38 \mathrm{a}$} & 1 & $5 / 18 / 2020$ & $13: 56$ & 8 & 0 & $14: 12$ & 8 & $14: 20$ & 8 \\
\hline & 2 & $6 / 11 / 2020$ & $13: 44$ & 6 & 0 & $13: 51$ & 5 & $13: 56$ & 7 \\
\hline & 3 & $7 / 13 / 2020$ & $13: 39$ & 6 & 0 & $13: 45$ & 5 & $13: 50$ & 6 \\
\hline & 4 & $7 / 29 / 2020$ & $9: 39$ & 4 & 0 & $9: 43$ & 7 & $9: 50$ & 5 \\
\hline \multirow[t]{4}{*}{$39 a$} & 1 & $5 / 18 / 2020$ & $14: 20$ & 11 & 0 & $14: 32$ & 8 & $14: 40$ & 11 \\
\hline & 2 & $6 / 11 / 2020$ & $14: 17$ & 6 & 0 & $14: 23$ & 6 & $14: 31$ & 6 \\
\hline & 3 & $7 / 13 / 2020$ & $14: 07$ & 7 & 0 & $14: 14$ & 6 & $14: 20$ & 5 \\
\hline & 4 & $7 / 29 / 2020$ & $9: 17$ & 4 & 0 & $9: 21$ & 5 & $9: 26$ & 5 \\
\hline \multirow[t]{4}{*}{$40 a$} & 1 & $5 / 22 / 2020$ & $11: 45$ & 7 & 0 & $11: 53$ & 7 & $12: 02$ & 8 \\
\hline & 2 & $6 / 11 / 2020$ & $14: 49$ & 6 & 0 & $14: 55$ & 6 & $15: 03$ & 7 \\
\hline & 3 & $7 / 13 / 2020$ & $14: 43$ & 7 & 0 & $14: 50$ & 6 & $14: 59$ & 7 \\
\hline & 4 & $7 / 29 / 2020$ & $8: 51$ & 7 & 0 & $8: 58$ & 5 & 9:03 & 6 \\
\hline \multirow[t]{4}{*}{$1 b$} & 1 & $5 / 25 / 2020$ & $9: 39$ & 6 & 0 & $9: 46$ & 5 & $9: 51$ & 5 \\
\hline & 2 & $6 / 12 / 2020$ & $10: 54$ & 5 & 0 & $10: 59$ & 5 & 11:05 & 5 \\
\hline & 3 & $7 / 14 / 2020$ & $10: 02$ & 7 & 0 & 10:09 & 4 & $10: 13$ & 5 \\
\hline & 4 & $8 / 1 / 2020$ & $8: 02$ & 8 & 0 & $8: 10$ & 6 & $9: 52$ & 8 \\
\hline \multirow[t]{2}{*}{$2 b$} & 1 & $5 / 21 / 2020$ & $8: 46$ & 7 & 0 & $8: 54$ & 6 & 9:02 & 8 \\
\hline & 2 & $6 / 12 / 2020$ & $10: 19$ & 8 & 0 & $10: 28$ & 5 & $10: 35$ & 5 \\
\hline
\end{tabular}




\begin{tabular}{|c|c|c|c|c|c|c|c|c|}
\hline 3 & $7 / 14 / 2020$ & $8: 27$ & 7 & 0 & $8: 34$ & 7 & $9: 49$ & 4 \\
\hline 4 & $8 / 1 / 2020$ & $8: 24$ & 6 & 0 & $8: 30$ & 6 & $9: 41$ & 5 \\
\hline $3 b$ & $5 / 25 / 2020$ & $8: 46$ & 7 & 0 & $8: 54$ & 6 & 9:01 & 6 \\
\hline 2 & $6 / 14 / 2020$ & $9: 41$ & 5 & 0 & $9: 46$ & 5 & $9: 51$ & 7 \\
\hline 3 & $7 / 14 / 2020$ & $8: 50$ & 6 & 0 & $8: 56$ & 6 & $9: 36$ & 6 \\
\hline 4 & $8 / 1 / 2020$ & $8: 46$ & 5 & 0 & $8: 51$ & 5 & $9: 31$ & 5 \\
\hline \multirow[t]{4}{*}{$4 b$} & $5 / 19 / 2020$ & $8: 59$ & 9 & 0 & 9:09 & 5 & $9: 14$ & 7 \\
\hline & $6 / 14 / 2020$ & $8: 48$ & 6 & 0 & $8: 55$ & 6 & 9:01 & 6 \\
\hline & $7 / 10 / 2020$ & $13: 50$ & 4 & 0 & $13: 54$ & 5 & $14: 00$ & 5 \\
\hline & $7 / 28 / 2020$ & $9: 13$ & 6 & 0 & 9:19 & 6 & $9: 25$ & 5 \\
\hline \multirow[t]{4}{*}{$5 b$} & $5 / 19 / 2020$ & $8: 29$ & 7 & 0 & $8: 36$ & 6 & $9: 25$ & 7 \\
\hline & $6 / 12 / 2020$ & $9: 22$ & 7 & 0 & $9: 30$ & 6 & $9: 36$ & 5 \\
\hline & $7 / 10 / 2020$ & $14: 16$ & 5 & 0 & $14: 21$ & 4 & $14: 25$ & 5 \\
\hline & $7 / 28 / 2020$ & $9: 38$ & 6 & 0 & $9: 44$ & 6 & 9:50 & 5 \\
\hline \multirow[t]{4}{*}{$6 b$} & $5 / 25 / 2020$ & $9: 15$ & 6 & 0 & $9: 23$ & 3 & $9: 27$ & 6 \\
\hline & $6 / 12 / 2020$ & 9:01 & 6 & 0 & 9:07 & 4 & 9:11 & 4 \\
\hline & $7 / 10 / 2020$ & $13: 20$ & 5 & 0 & $13: 25$ & 4 & $13: 30$ & 5 \\
\hline & $7 / 28 / 2020$ & $8: 48$ & 5 & 0 & $8: 53$ & 7 & 9:00 & 7 \\
\hline \multirow[t]{4}{*}{$7 b$} & $5 / 25 / 2020$ & $10: 13$ & 7 & 0 & $10: 21$ & 5 & $10: 28$ & 7 \\
\hline & $6 / 12 / 2020$ & $11: 50$ & 8 & 0 & $12: 00$ & 6 & 12:08 & 6 \\
\hline & $7 / 14 / 2020$ & $10: 30$ & 5 & 0 & $10: 35$ & 5 & $10: 40$ & 6 \\
\hline & $8 / 1 / 2020$ & 10:08 & 5 & 0 & $10: 13$ & 4 & $10: 17$ & 4 \\
\hline \multirow[t]{4}{*}{$8 b$} & $5 / 25 / 2020$ & $10: 45$ & 4 & 0 & $10: 51$ & 6 & $10: 59$ & 7 \\
\hline & $6 / 14 / 2020$ & $10: 16$ & 5 & 0 & $10: 21$ & 5 & $10: 26$ & 5 \\
\hline & $7 / 14 / 2020$ & $10: 56$ & 4 & 0 & $11: 00$ & 5 & 11:05 & 5 \\
\hline & $8 / 1 / 2020$ & $10: 30$ & 5 & 0 & $10: 35$ & 5 & $10: 40$ & 6 \\
\hline $9 b$ & $5 / 21 / 2020$ & $9: 31$ & 8 & 0 & $9: 40$ & 5 & $9: 45$ & 8 \\
\hline 2 & $6 / 14 / 2020$ & $10: 46$ & 5 & 0 & $10: 51$ & 4 & $10: 55$ & 5 \\
\hline 3 & $7 / 14 / 2020$ & $11: 17$ & 6 & 0 & $11: 23$ & 7 & $11: 30$ & 7 \\
\hline 4 & $8 / 1 / 2020$ & $10: 53$ & 7 & 0 & $11: 00$ & 5 & 11:05 & 6 \\
\hline $0 \mathrm{~b}$ & $5 / 21 / 2020$ & $10: 42$ & 5 & 0 & $10: 47$ & 5 & $10: 53$ & 7 \\
\hline 2 & $6 / 12 / 2020$ & $12: 28$ & 6 & 0 & $12: 34$ & 6 & $12: 41$ & 5 \\
\hline 3 & $7 / 14 / 2020$ & $12: 29$ & 5 & 0 & $12: 34$ & 6 & $12: 40$ & 5 \\
\hline 4 & $8 / 1 / 2020$ & $12: 00$ & 7 & 0 & $12: 07$ & 5 & $12: 12$ & 5 \\
\hline $1 b$ & $5 / 21 / 2020$ & 11:06 & 6 & 0 & $11: 12$ & 6 & $11: 19$ & 4 \\
\hline 2 & $6 / 14 / 2020$ & $11: 19$ & 6 & 0 & $11: 25$ & 5 & $11: 30$ & 5 \\
\hline 3 & $7 / 14 / 2020$ & $12: 59$ & 6 & 0 & $13: 05$ & 7 & $13: 12$ & 8 \\
\hline 4 & $8 / 1 / 2020$ & $12: 31$ & 6 & 0 & $12: 37$ & 5 & $12: 42$ & 5 \\
\hline \multirow[t]{3}{*}{$12 \mathrm{~b}$} & $5 / 19 / 2020$ & $9: 39$ & 7 & 0 & $9: 47$ & 7 & $9: 56$ & 8 \\
\hline & $6 / 14 / 2020$ & $9: 16$ & 6 & 0 & $9: 22$ & 4 & $9: 26$ & 6 \\
\hline & $7 / 14 / 2020$ & $9: 12$ & 6 & 0 & $9: 18$ & 5 & $9: 23$ & 7 \\
\hline
\end{tabular}




\begin{tabular}{|c|c|c|c|c|c|c|c|c|c|}
\hline & 4 & $8 / 1 / 2020$ & 9:04 & 6 & 0 & $9: 10$ & 5 & $9: 15$ & 5 \\
\hline \multirow[t]{4}{*}{$13 b$} & 1 & $5 / 19 / 2020$ & $10: 00$ & 9 & 0 & 10:11 & 8 & $10: 20$ & 8 \\
\hline & 2 & $6 / 12 / 2020$ & $9: 54$ & 6 & 0 & 10:00 & 5 & 10:06 & 5 \\
\hline & 3 & $7 / 10 / 2020$ & $12: 42$ & 6 & 0 & $12: 48$ & 6 & $12: 54$ & 6 \\
\hline & 4 & $7 / 28 / 2020$ & $10: 08$ & 6 & 0 & $10: 14$ & 4 & $10: 18$ & 5 \\
\hline \multirow[t]{4}{*}{$14 b$} & 1 & $5 / 21 / 2020$ & 10:09 & 6 & 0 & $10: 15$ & 5 & $10: 21$ & 5 \\
\hline & 2 & $6 / 12 / 2020$ & $11: 21$ & 7 & 0 & $11: 29$ & 5 & $11: 34$ & 6 \\
\hline & 3 & $7 / 14 / 2020$ & $11: 49$ & 8 & 0 & $11: 57$ & 7 & 12:04 & 6 \\
\hline & 4 & $8 / 1 / 2020$ & $11: 24$ & 6 & 0 & $11: 30$ & 7 & $11: 37$ & 6 \\
\hline \multirow[t]{4}{*}{$17 \mathrm{~b}$} & 1 & $5 / 23 / 2020$ & $14: 34$ & 5 & 0 & $14: 40$ & 5 & $14: 45$ & 6 \\
\hline & 2 & $6 / 10 / 2020$ & $11: 59$ & 6 & 0 & $12: 07$ & 5 & $12: 12$ & 7 \\
\hline & 3 & $7 / 11 / 2020$ & $10: 17$ & 7 & 0 & $10: 24$ & 5 & $10: 29$ & 9 \\
\hline & 4 & $7 / 30 / 2020$ & $11: 26$ & 5 & 0 & $11: 31$ & 6 & $11: 37$ & 5 \\
\hline \multirow[t]{4}{*}{$18 \mathrm{~b}$} & 1 & $5 / 23 / 2020$ & $15: 00$ & 5 & 0 & $15: 06$ & 7 & $15: 13$ & 7 \\
\hline & 2 & $6 / 10 / 2020$ & $12: 31$ & 5 & 0 & $12: 36$ & 5 & $12: 42$ & 6 \\
\hline & 3 & $7 / 11 / 2020$ & 11:08 & 5 & 0 & $11: 13$ & 7 & $11: 20$ & 6 \\
\hline & 4 & $7 / 30 / 2020$ & $11: 52$ & 6 & 0 & $11: 58$ & 6 & 12:04 & 6 \\
\hline \multirow[t]{4}{*}{$19 b$} & 1 & $5 / 23 / 2020$ & $14: 10$ & 5 & 0 & $13: 56$ & 5 & $14: 22$ & 4 \\
\hline & 2 & $6 / 10 / 2020$ & $11: 00$ & 5 & 0 & 11:06 & 5 & $11: 12$ & 7 \\
\hline & 3 & $7 / 11 / 2020$ & $9: 51$ & 5 & 0 & $9: 56$ & 5 & 10:01 & 7 \\
\hline & 4 & $7 / 30 / 2020$ & 11:01 & 7 & 0 & 11:08 & 4 & $11: 12$ & 5 \\
\hline \multirow[t]{4}{*}{$20 \mathrm{~b}$} & 1 & $5 / 23 / 2020$ & $15: 38$ & 7 & 0 & $15: 45$ & 7 & $15: 53$ & 8 \\
\hline & 2 & $6 / 10 / 2020$ & $11: 28$ & 6 & 0 & $11: 34$ & 6 & $11: 40$ & 5 \\
\hline & 3 & $7 / 11 / 2020$ & $10: 49$ & 5 & 0 & $10: 38$ & 5 & $10: 43$ & 7 \\
\hline & 4 & $7 / 30 / 2020$ & $12: 35$ & 6 & 0 & $12: 41$ & 6 & $12: 47$ & 4 \\
\hline \multirow[t]{4}{*}{$21 b$} & 1 & $5 / 23 / 2020$ & $13: 51$ & 5 & 0 & $14: 16$ & 5 & $14: 02$ & 5 \\
\hline & 2 & $6 / 10 / 2020$ & $10: 19$ & 6 & 0 & $10: 25$ & 5 & $10: 30$ & 4 \\
\hline & 3 & $7 / 11 / 2020$ & $8: 51$ & 6 & 0 & $8: 58$ & 6 & 9:04 & 6 \\
\hline & 4 & $7 / 30 / 2020$ & $10: 34$ & 4 & 0 & $10: 38$ & 5 & $10: 43$ & 7 \\
\hline \multirow[t]{4}{*}{$22 b$} & 1 & $5 / 23 / 2020$ & $10: 30$ & 5 & 0 & $10: 30$ & 5 & $10: 35$ & 4 \\
\hline & 2 & $6 / 12 / 2020$ & $15: 16$ & 4 & 0 & $15: 22$ & 8 & $15: 31$ & 6 \\
\hline & 3 & $7 / 11 / 2020$ & $14: 11$ & 5 & 0 & $14: 16$ & 4 & $14: 20$ & 5 \\
\hline & 4 & $7 / 30 / 2020$ & $14: 44$ & 7 & 0 & $14: 51$ & 5 & $14: 56$ & 7 \\
\hline \multirow[t]{4}{*}{$23 b$} & 1 & $5 / 21 / 2020$ & $11: 46$ & 7 & 0 & $11: 54$ & 6 & $12: 02$ & 8 \\
\hline & 2 & $6 / 12 / 2020$ & $14: 37$ & 5 & 0 & $14: 45$ & 7 & $14: 53$ & 7 \\
\hline & 3 & $7 / 11 / 2020$ & $13: 48$ & 5 & 0 & $13: 53$ & 5 & $13: 58$ & 5 \\
\hline & 4 & $7 / 30 / 2020$ & $14: 27$ & 5 & 0 & $14: 32$ & 5 & $14: 37$ & 5 \\
\hline \multirow[t]{4}{*}{$24 b$} & 1 & $5 / 23 / 2020$ & $12: 55$ & 6 & 0 & 13:01 & 6 & 13:07 & 5 \\
\hline & 2 & $6 / 10 / 2020$ & $9: 16$ & 6 & 0 & $9: 23$ & 7 & $9: 30$ & 5 \\
\hline & 3 & $7 / 11 / 2020$ & $12: 38$ & 5 & 0 & $12: 43$ & 5 & $12: 48$ & 5 \\
\hline & 4 & $7 / 30 / 2020$ & $9: 16$ & 5 & 0 & $9: 21$ & 5 & $9: 26$ & 5 \\
\hline
\end{tabular}




\begin{tabular}{|c|c|c|c|c|c|c|c|c|c|}
\hline \multirow[t]{4}{*}{$25 b$} & 1 & $5 / 23 / 2020$ & $13: 20$ & 6 & 0 & $13: 26$ & 4 & $13: 32$ & 5 \\
\hline & 2 & $6 / 10 / 2020$ & $9: 46$ & 6 & 0 & $9: 53$ & 7 & 10:01 & 7 \\
\hline & 3 & $7 / 11 / 2020$ & $12: 10$ & 6 & 0 & $12: 16$ & 5 & $12: 21$ & 5 \\
\hline & 4 & $7 / 30 / 2020$ & $9: 42$ & 5 & 0 & $9: 47$ & 5 & $9: 52$ & 7 \\
\hline \multirow[t]{4}{*}{$26 b$} & 1 & $5 / 23 / 2020$ & $13: 42$ & 5 & 0 & $13: 47$ & 5 & $13: 52$ & 5 \\
\hline & 2 & $6 / 10 / 2020$ & $10: 41$ & 4 & 0 & $10: 45$ & 4 & $10: 49$ & 5 \\
\hline & 3 & $7 / 11 / 2020$ & $9: 18$ & 5 & 0 & $9: 23$ & 6 & $9: 29$ & 6 \\
\hline & 4 & $7 / 30 / 2020$ & $10: 10$ & 5 & 0 & $10: 15$ & 5 & $10: 20$ & 6 \\
\hline \multirow[t]{4}{*}{$27 b$} & 1 & $5 / 23 / 2020$ & $10: 55$ & 5 & 0 & 11:01 & 6 & 11:08 & 5 \\
\hline & 2 & $6 / 12 / 2020$ & $14: 09$ & 4 & 0 & $14: 14$ & 5 & $14: 21$ & 7 \\
\hline & 3 & $7 / 11 / 2020$ & $14: 34$ & 4 & 0 & $14: 38$ & 5 & $14: 43$ & 6 \\
\hline & 4 & $7 / 30 / 2020$ & $14: 00$ & 5 & 0 & $14: 05$ & 5 & $14: 10$ & 6 \\
\hline \multirow[t]{4}{*}{$28 b$} & 1 & $5 / 19 / 2020$ & $11: 26$ & 9 & 0 & $11: 35$ & 5 & $11: 41$ & 8 \\
\hline & 2 & $6 / 12 / 2020$ & $13: 36$ & 5 & 0 & $13: 42$ & 5 & $13: 48$ & 6 \\
\hline & 3 & $7 / 10 / 2020$ & $15: 36$ & 6 & 0 & $15: 42$ & 7 & $15: 49$ & 6 \\
\hline & 4 & $7 / 28 / 2020$ & $10: 58$ & 8 & 0 & 11:06 & 6 & $10: 37$ & 5 \\
\hline \multirow[t]{4}{*}{$29 b$} & 1 & $5 / 19 / 2020$ & $10: 44$ & 7 & 0 & $10: 51$ & 9 & 11:01 & 9 \\
\hline & 2 & $6 / 12 / 2020$ & 13:09 & 6 & 0 & $13: 16$ & 5 & $13: 21$ & 5 \\
\hline & 3 & $7 / 10 / 2020$ & $14: 58$ & 6 & 0 & $15: 04$ & 6 & $15: 10$ & 5 \\
\hline & 4 & $7 / 28 / 2020$ & $10: 25$ & 6 & 0 & $10: 31$ & 6 & $10: 37$ & 5 \\
\hline \multirow[t]{4}{*}{$30 \mathrm{~b}$} & 1 & $5 / 23 / 2020$ & $12: 20$ & 5 & 0 & $12: 25$ & 7 & $12: 33$ & 7 \\
\hline & 2 & $6 / 10 / 2020$ & $8: 44$ & 7 & 0 & $8: 52$ & 6 & 9:00 & 6 \\
\hline & 3 & $7 / 11 / 2020$ & $13: 00$ & 4 & 0 & 13:04 & 5 & 13:09 & 6 \\
\hline & 4 & $7 / 20 / 2020$ & $8: 48$ & 8 & 0 & $8: 56$ & 6 & $9: 02$ & 6 \\
\hline \multirow[t]{4}{*}{$31 b$} & 1 & $5 / 23 / 2020$ & $11: 26$ & 8 & 0 & $11: 35$ & 7 & $11: 42$ & 8 \\
\hline & 2 & $6 / 14 / 2020$ & $11: 59$ & 7 & 0 & $12: 07$ & 5 & 12:12 & 5 \\
\hline & 3 & $7 / 10 / 2020$ & $9: 20$ & 4 & 0 & $9: 24$ & 4 & $9: 28$ & 7 \\
\hline & 4 & $7 / 30 / 2020$ & $15: 31$ & 7 & 0 & $15: 38$ & 4 & $15: 42$ & 7 \\
\hline \multirow[t]{4}{*}{$32 b$} & 1 & $5 / 19 / 2020$ & $12: 21$ & 7 & 0 & $12: 29$ & 5 & $12: 35$ & 7 \\
\hline & 2 & $6 / 14 / 2020$ & $12: 28$ & 4 & 0 & $12: 32$ & 5 & $12: 37$ & 5 \\
\hline & 3 & $7 / 11 / 2020$ & $15: 00$ & 5 & 0 & $15: 05$ & 4 & 15:09 & 5 \\
\hline & 4 & $7 / 30 / 2020$ & $13: 32$ & 5 & 0 & $13: 37$ & 6 & $13: 43$ & 7 \\
\hline \multirow[t]{4}{*}{$33 b$} & 1 & $5 / 19 / 2020$ & $12: 50$ & 7 & 0 & $12: 57$ & 6 & 13:03 & 7 \\
\hline & 2 & $6 / 10 / 2020$ & $13: 29$ & 5 & 0 & $13: 34$ & 6 & $13: 40$ & 5 \\
\hline & 3 & $7 / 10 / 2020$ & $8: 52$ & 6 & 0 & $8: 58$ & 8 & 9:06 & 5 \\
\hline & 4 & $7 / 28 / 2020$ & $11: 13$ & 7 & 0 & $11: 20$ & 6 & $11: 26$ & 8 \\
\hline \multirow[t]{4}{*}{$34 b$} & 1 & $5 / 19 / 2020$ & $13: 15$ & 6 & 0 & $13: 21$ & 6 & $13: 27$ & 5 \\
\hline & 2 & $6 / 10 / 2020$ & $13: 55$ & 6 & 0 & $14: 01$ & 8 & 14:09 & 5 \\
\hline & 3 & $7 / 10 / 2020$ & $9: 42$ & 4 & 0 & $9: 46$ & 4 & $9: 50$ & 5 \\
\hline & 4 & $7 / 27 / 2020$ & $11: 42$ & 5 & 0 & $11: 47$ & 5 & $11: 52$ & 7 \\
\hline $35 b$ & 1 & $5 / 21 / 2020$ & $12: 49$ & 7 & 0 & $12: 57$ & 6 & 13:05 & 5 \\
\hline
\end{tabular}




\begin{tabular}{|c|c|c|c|c|c|c|c|c|c|}
\hline & 2 & $6 / 14 / 2020$ & $13: 34$ & 6 & 0 & $13: 40$ & 5 & $13: 45$ & 5 \\
\hline & 3 & $7 / 11 / 2020$ & $15: 23$ & 5 & 0 & $15: 28$ & 6 & $15: 34$ & 4 \\
\hline & 4 & $7 / 28 / 2020$ & $12: 08$ & 6 & 0 & $12: 14$ & 6 & $12: 20$ & 5 \\
\hline \multirow[t]{4}{*}{$36 b$} & 1 & $5 / 21 / 2020$ & $12: 21$ & 6 & 0 & $12: 27$ & 8 & $12: 36$ & 6 \\
\hline & 2 & $6 / 14 / 2020$ & 13:01 & 7 & 0 & 13:08 & 6 & $13: 14$ & 6 \\
\hline & 3 & $7 / 10 / 2020$ & 10:01 & 5 & 0 & 10:06 & 5 & $10: 11$ & 5 \\
\hline & 4 & $7 / 28 / 2020$ & $12: 36$ & 5 & 0 & $12: 41$ & 5 & $12: 46$ & 5 \\
\hline \multirow[t]{4}{*}{$37 b$} & 1 & $5 / 23 / 2020$ & $9: 40$ & 5 & 0 & 9:46 & 5 & $9: 52$ & 8 \\
\hline & 2 & $6 / 10 / 2020$ & $14: 25$ & 5 & 0 & $14: 30$ & 4 & $14: 35$ & 5 \\
\hline & 3 & $7 / 10 / 2020$ & $10: 23$ & 6 & 0 & $10: 30$ & 5 & $10: 35$ & 5 \\
\hline & 4 & $7 / 28 / 2020$ & 13:02 & 6 & 0 & 13:08 & 6 & $13: 14$ & 6 \\
\hline \multirow[t]{4}{*}{$38 b$} & 1 & $5 / 19 / 2020$ & $14: 16$ & 8 & 0 & $14: 27$ & 10 & $14: 41$ & 8 \\
\hline & 2 & $6 / 10 / 2020$ & $14: 51$ & 5 & 0 & $14: 57$ & 6 & 15:04 & 6 \\
\hline & 3 & $7 / 10 / 2020$ & $10: 47$ & 6 & 0 & $10: 53$ & 7 & 11:01 & 4 \\
\hline & 4 & $7 / 28 / 2020$ & $13: 31$ & 7 & 0 & $13: 38$ & 5 & $13: 43$ & 5 \\
\hline \multirow[t]{4}{*}{$39 b$} & 1 & $5 / 21 / 2020$ & $14: 09$ & 8 & 0 & $14: 18$ & 7 & $14: 27$ & 7 \\
\hline & 2 & $6 / 13 / 2020$ & $14: 55$ & 5 & 0 & $15: 00$ & 7 & 15:08 & 6 \\
\hline & 3 & $7 / 11 / 2020$ & $15: 45$ & 5 & 0 & $15: 50$ & 4 & $15: 54$ & 6 \\
\hline & 4 & $7 / 28 / 2020$ & $13: 59$ & 8 & 0 & 14:07 & 5 & $14: 12$ & 5 \\
\hline \multirow[t]{4}{*}{$40 \mathrm{~b}$} & 1 & $5 / 23 / 2020$ & $9: 15$ & 5 & 0 & $9: 21$ & 5 & $9: 26$ & 5 \\
\hline & 2 & $6 / 10 / 2020$ & $15: 20$ & 6 & 0 & $15: 27$ & 7 & $15: 35$ & 6 \\
\hline & 3 & $7 / 10 / 2020$ & $11: 38$ & 4 & 0 & $11: 42$ & 5 & $11: 47$ & 5 \\
\hline & 4 & $7 / 28 / 2020$ & $14: 31$ & 5 & 0 & $14: 36$ & 5 & $14: 41$ & 7 \\
\hline \multirow[t]{4}{*}{$41 b$} & 1 & $5 / 23 / 2020$ & $8: 46$ & 6 & 0 & $8: 53$ & 7 & $9: 01$ & 7 \\
\hline & 2 & $6 / 13 / 2020$ & $14: 21$ & 7 & 0 & $14: 28$ & 6 & $14: 35$ & 5 \\
\hline & 3 & $7 / 10 / 2020$ & $12: 01$ & 4 & 0 & 12:05 & 5 & $12: 10$ & 6 \\
\hline & 4 & $7 / 28 / 2020$ & $14: 59$ & 7 & 0 & $15: 06$ & 5 & $15: 11$ & 5 \\
\hline \multirow[t]{4}{*}{$42 b$} & 1 & $5 / 21 / 2020$ & $13: 30$ & 8 & 0 & $13: 40$ & 7 & $13: 48$ & 7 \\
\hline & 2 & $6 / 13 / 2020$ & $15: 22$ & 5 & 0 & $15: 28$ & 7 & $15: 37$ & 7 \\
\hline & 3 & $7 / 10 / 2020$ & $11: 12$ & 5 & 0 & $11: 17$ & 5 & $11: 22$ & 5 \\
\hline & 4 & $7 / 28 / 2020$ & $15: 34$ & 6 & 0 & $15: 40$ & 6 & $15: 46$ & 5 \\
\hline
\end{tabular}


Appendix C: Recorded weather at the time of each survey. Temperature is in degrees Celsius, wind in $\mathrm{mph}$, and weather a categorical $(0=$ full sun, $1=$ partly cloudy, $2=$ overcast, $3=$ light rain, $4=$ medium rain).

\begin{tabular}{|c|c|c|c|c|c|c|c|c|c|c|c|}
\hline Site & Survey & Date & Temp & Wind & Weather & Site & Survey & Date & Temp & Wind & Weather \\
\hline \multirow[t]{4}{*}{$1 \mathrm{a}$} & 1 & $5 / 21 / 2019$ & 13.9 & 4.5 & 1 & $11 \mathrm{a}$ & 1 & $5 / 21 / 2019$ & 14.0 & 4.8 & 1 \\
\hline & 2 & $6 / 21 / 2019$ & 16.1 & 3.9 & 1 & & 2 & $6 / 28 / 2019$ & 22.8 & 1 & 1 \\
\hline & 3 & $7 / 5 / 2019$ & 22.2 & 0.2 & 2 & & 3 & $7 / 5 / 2019$ & 27.8 & 1.1 & 1 \\
\hline & 4 & $7 / 22 / 2019$ & 16.7 & 0.3 & 3 & & 4 & $7 / 25 / 2019$ & 25.6 & 1.5 & 1 \\
\hline \multirow[t]{4}{*}{$2 a$} & 1 & $5 / 23 / 2019$ & 16.1 & 4.5 & 1 & $12 \mathrm{a}$ & 1 & $5 / 24 / 2019$ & 13.3 & 5.2 & 1 \\
\hline & 2 & $6 / 19 / 2019$ & 22.8 & 1 & 1 & & 2 & 6/20/2019 & 19.4 & 0.4 & 2 \\
\hline & 3 & $7 / 8 / 2019$ & 21.1 & 0.2 & 2 & & 3 & $7 / 3 / 2019$ & 23.3 & 0.7 & 3 \\
\hline & 4 & $7 / 29 / 2019$ & 22.2 & 1.4 & 0 & & 4 & $7 / 26 / 2019$ & 24.4 & 0.5 & 0 \\
\hline \multirow[t]{4}{*}{$3 a$} & 1 & $5 / 23 / 2019$ & 16.1 & 5 & 1 & $13 a$ & 1 & $5 / 23 / 2019$ & 18.9 & 5 & 2 \\
\hline & 2 & $6 / 10 / 2019$ & 14.4 & 2.2 & 3 & & 2 & $6 / 20 / 2019$ & 20.0 & 0 & 2 \\
\hline & 3 & $7 / 5 / 2019$ & 23.9 & 0.3 & 2 & & 3 & $7 / 1 / 2019$ & 24.4 & 1.2 & 0 \\
\hline & 4 & $7 / 25 / 2019$ & 22.8 & 1.3 & 0 & & 4 & $7 / 22 / 2019$ & 20.0 & 0.2 & 2 \\
\hline \multirow[t]{4}{*}{$4 a$} & 1 & $5 / 21 / 2019$ & 19.0 & 5.2 & 1 & $14 \mathrm{a}$ & 1 & $5 / 23 / 2019$ & 19.4 & 5 & 2 \\
\hline & 2 & $6 / 20 / 2019$ & 18.3 & 0.3 & 3 & & 2 & $6 / 20 / 2019$ & 20.0 & 0 & 2 \\
\hline & 3 & $7 / 8 / 2019$ & 23.3 & 0.3 & 2 & & 3 & $7 / 5 / 2019$ & 27.2 & 1.3 & 1 \\
\hline & 4 & $7 / 29 / 2019$ & 27.8 & 1.2 & 1 & & 4 & $7 / 22 / 2019$ & 20.0 & 0.1 & 3 \\
\hline \multirow[t]{4}{*}{$5 a$} & 1 & $5 / 23 / 2019$ & 18.9 & 5 & 1 & $15 \mathrm{a}$ & 1 & $5 / 24 / 2019$ & 15.0 & 5 & 1 \\
\hline & 2 & $6 / 19 / 2019$ & 22.8 & 1 & 1 & & 2 & $6 / 19 / 2019$ & 23.9 & 1.3 & 1 \\
\hline & 3 & $7 / 1 / 2019$ & 20.0 & 1.3 & 0 & & 3 & $7 / 3 / 2019$ & 23.9 & 0.6 & 2 \\
\hline & 4 & $7 / 22 / 2019$ & 17.2 & 0.3 & 3 & & 4 & $7 / 25 / 2019$ & 28.9 & 1.1 & 1 \\
\hline \multirow[t]{4}{*}{$6 a$} & 1 & $5 / 22 / 2019$ & 11.7 & 0 & 0 & $16 \mathrm{a}$ & 1 & $5 / 22 / 2019$ & 13.3 & 1.5 & 0 \\
\hline & 2 & $6 / 10 / 2019$ & 17.8 & 4.2 & 1 & & 2 & $6 / 19 / 2019$ & 24.4 & 1 & 1 \\
\hline & 3 & 7/3/2019 & 22.2 & 0.5 & 2 & & 3 & 7/8/2019 & 23.9 & 0.2 & 1 \\
\hline & 4 & $7 / 25 / 2019$ & 22.2 & 0.8 & 1 & & 4 & $7 / 30 / 2019$ & 29.4 & 0.7 & 0 \\
\hline \multirow[t]{4}{*}{$7 \mathrm{a}$} & 1 & $5 / 31 / 2019$ & 20.0 & 3 & 1 & $17 \mathrm{a}$ & 1 & $5 / 21 / 2019$ & 13.7 & 1.4 & 1 \\
\hline & 2 & $6 / 19 / 2019$ & 23.9 & 1.2 & 1 & & 2 & $6 / 19 / 2019$ & 23.9 & 0.7 & 1 \\
\hline & 3 & $7 / 5 / 2019$ & 27.8 & 1.2 & 1 & & 3 & $7 / 3 / 2019$ & 25.0 & 0.3 & 3 \\
\hline & 4 & $7 / 26 / 2019$ & 16.7 & 0.5 & 0 & & 4 & $7 / 25 / 2019$ & 29.4 & 0.9 & 1 \\
\hline \multirow[t]{4}{*}{$8 a$} & 1 & $5 / 24 / 2019$ & 12.8 & 5 & 1 & $18 \mathrm{a}$ & 1 & $5 / 24 / 2019$ & 16.7 & 6 & 1 \\
\hline & 2 & $6 / 10 / 2019$ & 16.1 & 4.1 & 1 & & 2 & $6 / 10 / 2019$ & 18.9 & 4 & 1 \\
\hline & 3 & $7 / 3 / 2019$ & 22.2 & 0.4 & 2 & & 3 & $7 / 10 / 2019$ & 19.4 & 0.6 & 0 \\
\hline & 4 & $7 / 26 / 2019$ & 22.8 & 0.4 & 0 & & 4 & $7 / 30 / 2019$ & 30.6 & 1 & 0 \\
\hline \multirow[t]{4}{*}{$9 a$} & 1 & $5 / 31 / 2019$ & 18.3 & 3.1 & 1 & $19 \mathrm{a}$ & 1 & $5 / 31 / 2019$ & 17.8 & 2.1 & 1 \\
\hline & 2 & $6 / 20 / 2019$ & 18.9 & 0.2 & 2 & & 2 & $6 / 20 / 2019$ & 20.6 & 0 & 2 \\
\hline & 3 & $7 / 8 / 2019$ & 23.3 & 0.6 & 1 & & 3 & $7 / 10 / 2019$ & 20.6 & 0.2 & 0 \\
\hline & 4 & $7 / 30 / 2019$ & 26.1 & 0.5 & 0 & & 4 & $7 / 30 / 2019$ & 30.6 & 0.5 & 1 \\
\hline
\end{tabular}




\begin{tabular}{|c|c|c|c|c|c|c|c|c|c|c|c|}
\hline \multirow[t]{4}{*}{$10 \mathrm{a}$} & 1 & $5 / 31 / 2019$ & 18.3 & 2.3 & 1 & $20 a$ & 1 & $5 / 21 / 2019$ & 13.2 & 5 & 1 \\
\hline & 2 & $6 / 20 / 2019$ & 18.9 & 0.3 & 3 & & 2 & $6 / 18 / 2019$ & 22.2 & 1.3 & 1 \\
\hline & 3 & $7 / 1 / 2019$ & 20.6 & 1.5 & 0 & & 3 & $7 / 1 / 2019$ & 26.7 & 1.1 & 0 \\
\hline & 4 & $7 / 25 / 2019$ & 23.9 & 1.3 & 1 & & 4 & $7 / 22 / 2019$ & 17.8 & 0.2 & 3 \\
\hline \multirow[t]{4}{*}{$21 \mathrm{a}$} & 1 & $5 / 24 / 2019$ & 17.2 & 8 & 1 & $31 \mathrm{a}$ & 1 & $5 / 21 / 2019$ & 20.6 & 2.5 & 1 \\
\hline & 2 & $6 / 10 / 2019$ & 22.8 & 4 & 1 & & 2 & $6 / 21 / 2019$ & 17.2 & 4 & 1 \\
\hline & 3 & 7/8/2019 & 21.7 & 0.2 & 2 & & 3 & $7 / 10 / 2019$ & 27.2 & 0.8 & 1 \\
\hline & 4 & $7 / 30 / 2019$ & 31.7 & 3.4 & 1 & & 4 & $7 / 29 / 2019$ & 26.1 & 1.4 & 0 \\
\hline \multirow[t]{4}{*}{$22 \mathrm{a}$} & 1 & $5 / 22 / 2019$ & 18.1 & 2 & 1 & $32 \mathrm{a}$ & 1 & $5 / 31 / 2019$ & 23.9 & 3 & 1 \\
\hline & 2 & $6 / 18 / 2019$ & 22.8 & 1 & 1 & & 2 & $6 / 19 / 2019$ & 20.6 & 0.5 & 1 \\
\hline & 3 & 7/3/2019 & 23.9 & 0.4 & 2 & & 3 & 7/8/2019 & 20.0 & 0 & 2 \\
\hline & 4 & $7 / 26 / 2019$ & 25.6 & 0.4 & 1 & & 4 & $7 / 29 / 2019$ & 25.6 & 1.4 & 0 \\
\hline \multirow[t]{4}{*}{$23 a$} & 1 & $5 / 22 / 2019$ & 18.3 & 2 & 1 & $33 a$ & 1 & $5 / 21 / 2019$ & 21.7 & 7 & 1 \\
\hline & 2 & $6 / 10 / 2019$ & 17.2 & 3.7 & 1 & & 2 & $6 / 19 / 2019$ & 21.1 & 0.6 & 1 \\
\hline & 3 & $7 / 5 / 2019$ & 25.0 & 1.4 & 1 & & 3 & 7/3/2019 & 20.0 & 0.2 & 3 \\
\hline & 4 & $7 / 22 / 2019$ & 17.2 & 0.3 & 3 & & 4 & $7 / 25 / 2019$ & 22.2 & 1.6 & 0 \\
\hline \multirow[t]{4}{*}{$24 a$} & 1 & $5 / 24 / 2019$ & 16.7 & 4 & 1 & $34 a$ & 1 & $5 / 22 / 2019$ & 23.3 & 1.5 & 2 \\
\hline & 2 & $6 / 20 / 2019$ & 20.6 & 0.4 & 2 & & 2 & $6 / 21 / 2019$ & 17.2 & 4.2 & 1 \\
\hline & 3 & 7/8/2019 & 21.1 & 0.2 & 2 & & 3 & 7/8/2019 & 20.6 & 0.1 & 2 \\
\hline & 4 & $7 / 30 / 2019$ & 32.2 & 1.5 & 1 & & 4 & $7 / 29 / 2019$ & 26.1 & 1.2 & 1 \\
\hline \multirow[t]{4}{*}{$25 \mathrm{a}$} & 1 & $5 / 23 / 2019$ & 18.9 & 5.5 & 2 & $35 a$ & 1 & $5 / 21 / 2019$ & 21.7 & 12 & 1 \\
\hline & 2 & $6 / 18 / 2019$ & 22.2 & 1.5 & 1 & & 2 & $6 / 21 / 2019$ & 17.8 & 4.1 & 1 \\
\hline & 3 & 7/1/2019 & 26.7 & 1.5 & 0 & & 3 & $7 / 5 / 2019$ & 25.0 & 0.4 & 2 \\
\hline & 4 & $7 / 26 / 2019$ & 25.6 & 0.8 & 1 & & 4 & $7 / 22 / 2019$ & 16.7 & 0.3 & 3 \\
\hline \multirow[t]{4}{*}{$26 a$} & 1 & $5 / 23 / 2019$ & 16.1 & 2 & 3 & $36 a$ & 1 & $5 / 31 / 2019$ & 23.3 & 3.1 & 1 \\
\hline & 2 & $6 / 18 / 2019$ & 22.2 & 1.1 & 1 & & 2 & $6 / 21 / 2019$ & 18.3 & 4.3 & 1 \\
\hline & 3 & 7/1/2019 & 27.8 & 1 & 0 & & 3 & $7 / 10 / 2019$ & 28.9 & 0.9 & 1 \\
\hline & 4 & $7 / 26 / 2019$ & 23.9 & 0.4 & 1 & & 4 & $7 / 29 / 2019$ & 26.1 & 1 & 1 \\
\hline \multirow[t]{4}{*}{$27 \mathrm{a}$} & 1 & $5 / 21 / 2019$ & 16.4 & 4.8 & 1 & $37 a$ & 1 & $5 / 23 / 2019$ & 13.3 & 4 & 1 \\
\hline & 2 & $6 / 18 / 2019$ & 21.1 & 1.2 & 1 & & 2 & $6 / 21 / 2019$ & 19.4 & 4.5 & 1 \\
\hline & 3 & $7 / 10 / 2019$ & 22.2 & 1 & 0 & & 3 & $7 / 10 / 2019$ & 30.0 & 0.9 & 1 \\
\hline & 4 & 7/30/2019 & 32.2 & 1.4 & 1 & & 4 & $7 / 29 / 2019$ & 27.8 & 1.3 & 1 \\
\hline \multirow[t]{4}{*}{$28 \mathrm{a}$} & 1 & $5 / 22 / 2019$ & 18.9 & 0 & 1 & $38 \mathrm{a}$ & 1 & $5 / 31 / 2019$ & 22.8 & 3.1 & 1 \\
\hline & 2 & $6 / 10 / 2019$ & 20.0 & 3.5 & 1 & & 2 & $6 / 21 / 2019$ & 20.6 & 4 & 1 \\
\hline & 3 & $7 / 10 / 2019$ & 25.6 & 0.4 & 1 & & 3 & $7 / 5 / 2019$ & 26.1 & 0.2 & 2 \\
\hline & 4 & $7 / 30 / 2019$ & 32.2 & 1.5 & 1 & & 4 & $7 / 22 / 2019$ & 16.7 & 0.2 & 2 \\
\hline \multirow[t]{4}{*}{$29 a$} & 1 & $5 / 23 / 2019$ & 16.7 & 4 & 3 & $39 a$ & 1 & $5 / 22 / 2019$ & 23.9 & 10 & 1 \\
\hline & 2 & $6 / 18 / 2019$ & 20.6 & 1.2 & 2 & & 2 & $6 / 10 / 2019$ & 14.4 & 2 & 3 \\
\hline & 3 & $7 / 1 / 2019$ & 27.2 & 1.4 & 0 & & 3 & 7/3/2019 & 20.0 & 0.4 & 3 \\
\hline & 4 & $7 / 25 / 2019$ & 28.9 & 1.3 & 1 & & 4 & $7 / 25 / 2019$ & 17.2 & 1.1 & 0 \\
\hline $30 \mathrm{a}$ & 1 & $5 / 31 / 2019$ & 16.7 & 1.8 & 0 & $40 \mathrm{a}$ & 1 & $5 / 22 / 2019$ & 21.1 & 2 & 1 \\
\hline
\end{tabular}




\begin{tabular}{|c|c|c|c|c|c|c|c|c|c|c|c|}
\hline & 2 & $6 / 18 / 2019$ & 20.6 & 1.1 & 2 & & 2 & $6 / 21 / 2019$ & 22.2 & 3.8 & 1 \\
\hline \multirow{5}{*}{$1 b$} & 3 & $7 / 1 / 2019$ & 27.8 & 1.6 & 0 & & 3 & $7 / 10 / 2019$ & 31.7 & 0.6 & 1 \\
\hline & 4 & $7 / 25 / 2019$ & 28.9 & 1.1 & 1 & & 4 & $7 / 29 / 2019$ & 28.9 & 1 & 1 \\
\hline & 1 & $5 / 28 / 2019$ & 15.6 & 3.4 & 2 & $11 b$ & 1 & $5 / 28 / 2019$ & 17.2 & 2.1 & 2 \\
\hline & 2 & $6 / 17 / 2019$ & 17.2 & 0.1 & 3 & & 2 & $6 / 12 / 2019$ & 22.2 & 2.2 & 1 \\
\hline & 3 & $7 / 11 / 2019$ & 20.6 & 0.2 & 1 & & 3 & $7 / 11 / 2019$ & 22.2 & 0.2 & 3 \\
\hline \multirow{3}{*}{$2 b$} & 4 & $7 / 31 / 2019$ & 21.1 & 0.4 & 2 & & 4 & $7 / 31 / 2019$ & 25.6 & 0.3 & 1 \\
\hline & 1 & $5 / 27 / 2019$ & 19.4 & 0 & 0 & $12 b$ & 1 & $5 / 30 / 2019$ & 16.7 & 0 & 3 \\
\hline & 2 & $6 / 14 / 2019$ & 16.7 & 3.6 & 1 & & 2 & $6 / 14 / 2019$ & 18.3 & 3.5 & 1 \\
\hline \multirow{5}{*}{$3 b$} & 3 & $7 / 11 / 2019$ & 23.9 & 0.3 & 1 & & 3 & $7 / 11 / 2019$ & 23.9 & 0.4 & 2 \\
\hline & 4 & $7 / 31 / 2019$ & 23.9 & 0.3 & 2 & & 4 & $7 / 31 / 2019$ & 23.9 & 0.3 & 2 \\
\hline & 1 & $5 / 30 / 2019$ & 18.3 & 0 & 3 & $13 b$ & 1 & $5 / 26 / 2019$ & 23.9 & 3 & 1 \\
\hline & 2 & $6 / 14 / 2019$ & 17.2 & 3.4 & 1 & & 2 & $6 / 12 / 2019$ & 20.6 & 2.1 & 1 \\
\hline & 3 & $7 / 12 / 2019$ & 23.9 & 0.3 & 2 & & 3 & $7 / 11 / 2019$ & 22.8 & 0.6 & 2 \\
\hline \multirow{3}{*}{$4 b$} & 4 & $7 / 31 / 2019$ & 23.9 & 0.3 & 2 & & 4 & $7 / 31 / 2019$ & 23.9 & 0.3 & 1 \\
\hline & 1 & $5 / 26 / 2019$ & 18.9 & 1 & 1 & $14 b$ & 1 & $5 / 28 / 2019$ & 16.7 & 2 & 3 \\
\hline & 2 & $6 / 11 / 2019$ & 14.4 & 2.7 & 0 & & 2 & $6 / 14 / 2019$ & 19.4 & 3 & 1 \\
\hline \multirow{5}{*}{$5 b$} & 3 & $7 / 11 / 2019$ & 23.3 & 0.4 & 3 & & 3 & $7 / 2 / 2019$ & 30.0 & 0.9 & 1 \\
\hline & 4 & $7 / 31 / 2019$ & 22.8 & 0.3 & 2 & & 4 & $7 / 24 / 2019$ & 23.9 & 0.9 & 1 \\
\hline & 1 & $5 / 27 / 2019$ & 18.9 & 0 & 0 & $17 b$ & 1 & $5 / 30 / 2019$ & 17.8 & 1 & 2 \\
\hline & 2 & $6 / 12 / 2019$ & 21.1 & 1.4 & 1 & & 2 & $6 / 13 / 2019$ & 17.8 & 2 & 2 \\
\hline & 3 & 7/2/2019 & 26.7 & 0.4 & 2 & & 3 & 7/2/2019 & 22.2 & 0.7 & 2 \\
\hline \multirow{3}{*}{$6 \mathrm{~b}$} & 4 & $7 / 23 / 2019$ & 18.3 & 1.2 & 1 & & 4 & $7 / 23 / 2019$ & 17.2 & 0.3 & 1 \\
\hline & 1 & $5 / 26 / 2019$ & 18.9 & 2 & 1 & $18 b$ & 1 & $5 / 26 / 2019$ & 24.4 & 3 & 2 \\
\hline & 2 & $6 / 12 / 2019$ & 22.2 & 1.8 & 1 & & 2 & $6 / 17 / 2019$ & 17.2 & 0 & 2 \\
\hline \multirow{5}{*}{$7 b$} & 3 & $7 / 2 / 2019$ & 26.7 & 0.8 & 2 & & 3 & 7/9/2019 & 20.0 & 0.1 & 2 \\
\hline & 4 & $7 / 23 / 2019$ & 19.4 & 1.2 & 1 & & 4 & $8 / 1 / 2019$ & 24.4 & 0.2 & 1 \\
\hline & 1 & $5 / 27 / 2019$ & 16.1 & 0 & 0 & $19 b$ & 1 & $5 / 26 / 2019$ & 23.3 & 4 & 3 \\
\hline & 2 & $6 / 14 / 2019$ & 18.3 & 2.8 & 1 & & 2 & $6 / 12 / 2019$ & 18.1 & 0.9 & 1 \\
\hline & 3 & $7 / 2 / 2019$ & 28.9 & 0.3 & 2 & & 3 & $7 / 4 / 2019$ & 22.2 & 0.2 & 1 \\
\hline \multirow{3}{*}{$8 b$} & 4 & $7 / 24 / 2019$ & 26.1 & 1 & 1 & & 4 & $7 / 23 / 2019$ & 17.2 & 0.9 & 1 \\
\hline & 1 & $5 / 26 / 2019$ & 22.2 & 2 & 1 & $20 \mathrm{~b}$ & 1 & $5 / 26 / 2019$ & 24.4 & 2 & 3 \\
\hline & 2 & $6 / 17 / 2019$ & 17.8 & 0.4 & 2 & & 2 & $6 / 12 / 2019$ & 20.0 & 1 & 1 \\
\hline \multirow{5}{*}{$9 b$} & 3 & 7/2/2019 & 30.0 & 0.8 & 1 & & 3 & $7 / 2 / 2019$ & 21.7 & 0.8 & 2 \\
\hline & 4 & $7 / 24 / 2019$ & 26.1 & 0.9 & 1 & & 4 & $7 / 24 / 2019$ & 22.8 & 1.2 & 1 \\
\hline & 1 & $5 / 28 / 2019$ & 16.7 & 3.2 & 2 & $21 b$ & 1 & $5 / 30 / 2019$ & 17.2 & 1 & 2 \\
\hline & 2 & $6 / 14 / 2019$ & 19.4 & 2.8 & 1 & & 2 & $6 / 12 / 2019$ & 20.0 & 2.1 & 1 \\
\hline & 3 & $7 / 2 / 2019$ & 30.0 & 0.9 & 2 & & 3 & $7 / 12 / 2019$ & 28.9 & 0.9 & 1 \\
\hline \multirow{3}{*}{$10 \mathrm{~b}$} & 4 & $7 / 24 / 2019$ & 25.0 & 0.9 & 1 & & 4 & 8/1/2019 & 26.7 & 0.3 & 1 \\
\hline & 1 & $5 / 26 / 2019$ & 22.8 & 2.5 & 1 & $22 b$ & 1 & $5 / 27 / 2019$ & 19.4 & 0 & 1 \\
\hline & 2 & $6 / 12 / 2019$ & 22.8 & 2.1 & 1 & & 2 & $6 / 13 / 2019$ & 16.7 & 1.9 & 2 \\
\hline
\end{tabular}




\begin{tabular}{|c|c|c|c|c|c|c|c|c|c|c|c|}
\hline & 3 & $7 / 11 / 2019$ & 23.3 & 0.4 & 2 & & 3 & $7 / 4 / 2019$ & 28.3 & 0.2 & 1 \\
\hline & 4 & $7 / 31 / 2019$ & 25.6 & 0.7 & 1 & & 4 & $7 / 23 / 2019$ & 21.7 & 0.8 & 2 \\
\hline \multirow[t]{4}{*}{$23 b$} & 1 & $5 / 27 / 2019$ & 20.0 & 0 & 1 & $33 b$ & 1 & $5 / 29 / 2019$ & 23.9 & 2.1 & 1 \\
\hline & 2 & $6 / 13 / 2019$ & 17.8 & 1.7 & 2 & & 2 & $6 / 11 / 2019$ & 23.3 & 3.2 & 0 \\
\hline & 3 & $7 / 4 / 2019$ & 30.6 & 0.2 & 1 & & 3 & 7/9/2019 & 28.3 & 1.1 & 1 \\
\hline & 4 & $7 / 23 / 2019$ & 21.7 & 0.8 & 2 & & 4 & $8 / 2 / 2019$ & 21.7 & 0.3 & 1 \\
\hline \multirow[t]{4}{*}{$24 b$} & 1 & $5 / 30 / 2019$ & 17.2 & 1 & 2 & $34 b$ & 1 & $5 / 29 / 2019$ & 23.3 & 2.1 & 1 \\
\hline & 2 & $6 / 17 / 2019$ & 18.8 & 0.2 & 2 & & 2 & $6 / 17 / 2019$ & 19.4 & 0.5 & 3 \\
\hline & 3 & 7/9/2019 & 20.0 & 0 & 2 & & 3 & 7/9/2019 & 28.3 & 1.2 & 1 \\
\hline & 4 & $8 / 1 / 2019$ & 21.7 & 0.2 & 1 & & 4 & $8 / 2 / 2019$ & 17.8 & 0.1 & 0 \\
\hline \multirow[t]{4}{*}{$25 b$} & 1 & $5 / 28 / 2019$ & 15.6 & 1 & 2 & $35 b$ & 1 & $5 / 29 / 2019$ & 23.3 & 1.9 & 1 \\
\hline & 2 & $6 / 17 / 2019$ & 18.3 & 0.3 & 2 & & 2 & $6 / 11 / 2019$ & 24.4 & 5 & 1 \\
\hline & 3 & 7/9/2019 & 17.8 & 0 & 2 & & 3 & 7/4/2019 & 26.1 & 0.4 & 2 \\
\hline & 4 & $8 / 1 / 2019$ & 20.0 & 0.2 & 1 & & 4 & $7 / 23 / 2019$ & 22.8 & 0.4 & 2 \\
\hline \multirow[t]{4}{*}{$26 b$} & 1 & $5 / 28 / 2019$ & 14.4 & 1 & 2 & $36 b$ & 1 & $5 / 30 / 2019$ & 17.8 & 0 & 3 \\
\hline & 2 & $6 / 14 / 2019$ & 15.0 & 3.6 & 1 & & 2 & $6 / 13 / 2019$ & 16.1 & 1.8 & 2 \\
\hline & 3 & $7 / 12 / 2019$ & 23.3 & 0.9 & 1 & & 3 & $7 / 9 / 2019$ & 28.9 & 0.9 & 1 \\
\hline & 4 & $8 / 1 / 2019$ & 28.3 & 0.4 & 1 & & 4 & $8 / 1 / 2019$ & 28.3 & 0.2 & 1 \\
\hline \multirow[t]{4}{*}{$27 \mathrm{~b}$} & 1 & $5 / 29 / 2019$ & 22.8 & 2.1 & 2 & $37 b$ & 1 & $5 / 30 / 2019$ & 18.3 & 1 & 2 \\
\hline & 2 & $6 / 11 / 2019$ & 21.7 & 2.9 & 0 & & 2 & $6 / 13 / 2019$ & 15.6 & 1.6 & 3 \\
\hline & 3 & $7 / 12 / 2019$ & 20.6 & 2.2 & 1 & & 3 & $7 / 4 / 2019$ & 27.8 & 0.6 & 3 \\
\hline & 4 & 8/2/2019 & 26.1 & 0.3 & 1 & & 4 & $7 / 24 / 2019$ & 18.9 & 0.2 & 0 \\
\hline \multirow[t]{4}{*}{$28 b$} & 1 & $5 / 28 / 2019$ & 16.7 & 2 & 3 & $38 b$ & 1 & $5 / 29 / 2019$ & 22.8 & 1.9 & 1 \\
\hline & 2 & $6 / 17 / 2019$ & 17.8 & 0 & 3 & & 2 & $6 / 11 / 2019$ & 22.2 & 3.5 & 1 \\
\hline & 3 & $7 / 11 / 2019$ & 22.8 & 0.2 & 2 & & 3 & $7 / 4 / 2019$ & 22.8 & 0.6 & 3 \\
\hline & 4 & $7 / 31 / 2019$ & 26.7 & 0.4 & 1 & & 4 & $7 / 24 / 2019$ & 20.0 & 0.6 & 0 \\
\hline \multirow[t]{4}{*}{$29 b$} & 1 & $5 / 27 / 2019$ & 15.0 & 0 & 0 & $39 b$ & 1 & $5 / 27 / 2019$ & 22.8 & 1.6 & 1 \\
\hline & 2 & $6 / 17 / 2019$ & 17.8 & 0 & 3 & & 2 & $6 / 11 / 2019$ & 23.3 & 4.2 & 1 \\
\hline & 3 & $7 / 11 / 2019$ & 22.8 & 0.2 & 2 & & 3 & 7/9/2019 & 25.6 & 0.2 & 1 \\
\hline & 4 & $7 / 31 / 2019$ & 26.7 & 0.5 & 1 & & 4 & $8 / 1 / 2019$ & 28.9 & 0.2 & 1 \\
\hline \multirow[t]{4}{*}{$30 \mathrm{~b}$} & 1 & $5 / 28 / 2019$ & 15.0 & 1 & 2 & $40 \mathrm{~b}$ & 1 & $5 / 30 / 2019$ & 17.8 & 1 & 2 \\
\hline & 2 & $6 / 14 / 2019$ & 13.9 & 3.9 & 1 & & 2 & $6 / 13 / 2019$ & 14.4 & 2 & 3 \\
\hline & 3 & 7/9/2019 & 18.3 & 0 & 2 & & 3 & 7/9/2019 & 25.0 & 0.4 & 1 \\
\hline & 4 & $8 / 1 / 2019$ & 22.8 & 0.2 & 1 & & 4 & $8 / 1 / 2019$ & 27.2 & 0.1 & 1 \\
\hline \multirow[t]{4}{*}{$31 b$} & 1 & $5 / 29 / 2019$ & 20.0 & 2.4 & 2 & $41 b$ & 1 & $5 / 29 / 2019$ & 20.6 & 1.6 & 1 \\
\hline & 2 & $6 / 11 / 2019$ & 22.2 & 2.8 & 0 & & 2 & $6 / 13 / 2019$ & 13.9 & 1.9 & 3 \\
\hline & 3 & $7 / 12 / 2019$ & 20.6 & 1.4 & 1 & & 3 & 7/9/2019 & 25.0 & 0.4 & 1 \\
\hline & 4 & $8 / 2 / 2019$ & 26.1 & 0.5 & 1 & & 4 & $8 / 1 / 2019$ & 26.1 & 0.2 & 1 \\
\hline \multirow[t]{3}{*}{$32 b$} & 1 & $5 / 27 / 2019$ & 21.7 & 2 & 1 & $42 b$ & 1 & $5 / 29 / 2019$ & 21.7 & 1.8 & 1 \\
\hline & 2 & $6 / 11 / 2019$ & 22.2 & 3.1 & 0 & & 2 & $6 / 13 / 2019$ & 15.6 & 1.7 & 3 \\
\hline & 3 & $7 / 4 / 2019$ & 26.1 & 0.4 & 2 & & 3 & 7/4/2019 & 22.8 & 0.6 & 3 \\
\hline
\end{tabular}




\begin{tabular}{|c|c|c|c|c|c|c|c|c|c|c|c|}
\hline & 4 & $7 / 23 / 2019$ & 22.2 & 0.7 & 2 & & 4 & $7 / 24 / 2019$ & 16.1 & 0.3 & 0 \\
\hline \multirow[t]{4}{*}{$1 \mathrm{a}$} & 1 & $5 / 22 / 2020$ & 16.7 & 2 & 2 & $11 \mathrm{a}$ & 1 & $5 / 18 / 2020$ & 11.7 & 0.1 & 2 \\
\hline & 2 & $6 / 11 / 2020$ & 19.4 & 6 & 1 & & 2 & $6 / 13 / 2020$ & 13.9 & 3.5 & 1 \\
\hline & 3 & $7 / 13 / 2020$ & 20.0 & 1.5 & 0 & & 3 & $7 / 12 / 2020$ & 23.9 & 2.5 & 0 \\
\hline & 4 & $7 / 29 / 2020$ & 23.9 & 4 & 1 & & 4 & $7 / 27 / 2020$ & 23.3 & 3 & 0 \\
\hline \multirow[t]{4}{*}{$2 \mathrm{a}$} & 1 & $5 / 18 / 2020$ & 14.4 & 2 & 2 & $12 \mathrm{a}$ & 1 & $5 / 20 / 2020$ & 11.7 & 1.5 & 1 \\
\hline & 2 & $6 / 11 / 2020$ & 19.4 & 3 & 1 & & 2 & $6 / 8 / 2020$ & 16.1 & 2 & 0 \\
\hline & 3 & $7 / 13 / 2020$ & 20.6 & 1.5 & 0 & & 3 & $7 / 12 / 2020$ & 24.4 & 2.5 & 0 \\
\hline & 4 & $7 / 29 / 2020$ & 25.6 & 4 & 1 & & 4 & $7 / 31 / 2020$ & 22.8 & 2 & 1 \\
\hline \multirow[t]{4}{*}{$3 a$} & 1 & $5 / 22 / 2020$ & 16.7 & 2 & 2 & $13 \mathrm{a}$ & 1 & $5 / 24 / 2020$ & 17.8 & 2 & 2 \\
\hline & 2 & $6 / 11 / 2020$ & 20.6 & 4 & 2 & & 2 & $6 / 8 / 2020$ & 16.1 & 3 & 0 \\
\hline & 3 & $7 / 13 / 2020$ & 21.1 & 1.5 & 0 & & 3 & $7 / 9 / 2020$ & 23.9 & 1.5 & 0 \\
\hline & 4 & $7 / 24 / 2020$ & 26.1 & 4 & 1 & & 4 & $7 / 27 / 2020$ & 24.4 & 3 & 0 \\
\hline \multirow[t]{4}{*}{$4 a$} & 1 & $5 / 24 / 2020$ & 21.7 & 5 & 1 & $14 \mathrm{a}$ & 1 & $5 / 24 / 2020$ & 17.2 & 2 & 1 \\
\hline & 2 & $6 / 9 / 2020$ & 29.4 & 3 & 0 & & 2 & $6 / 8 / 2020$ & 17.2 & 3 & 0 \\
\hline & 3 & $7 / 12 / 2020$ & 22.2 & 2 & 0 & & 3 & $7 / 9 / 2020$ & 24.4 & 1 & 0 \\
\hline & 4 & $7 / 31 / 2020$ & 27.2 & 2 & 1 & & 4 & $7 / 31 / 2020$ & 23.3 & 2.5 & 1 \\
\hline \multirow[t]{4}{*}{$5 a$} & 1 & $5 / 22 / 2020$ & 21.1 & 1 & 1 & $15 \mathrm{a}$ & 1 & $5 / 24 / 2020$ & 17.8 & 2.5 & 1 \\
\hline & 2 & $6 / 13 / 2020$ & 16.7 & 3 & 1 & & 2 & $6 / 8 / 2020$ & 18.3 & 3 & 0 \\
\hline & 3 & $7 / 12 / 2020$ & 21.7 & 2 & 0 & & 3 & $7 / 12 / 2020$ & 25.0 & 3 & 0 \\
\hline & 4 & $7 / 31 / 2020$ & 27.2 & 2 & 1 & & 4 & $7 / 27 / 2020$ & 24.4 & 3 & 0 \\
\hline \multirow[t]{4}{*}{$6 a$} & 1 & $5 / 20 / 2020$ & 18.3 & 6 & 1 & $16 \mathrm{a}$ & 1 & $5 / 20 / 2020$ & 12.2 & 3 & 1 \\
\hline & 2 & $6 / 8 / 2020$ & 21.7 & 2 & 0 & & 2 & $6 / 13 / 2020$ & 11.7 & 2 & 1 \\
\hline & 3 & $7 / 12 / 2020$ & 20.6 & 2 & 0 & & 3 & $7 / 12 / 2020$ & 25.6 & 3 & 0 \\
\hline & 4 & $7 / 29 / 2020$ & 27.8 & 4 & 1 & & 4 & $7 / 27 / 2020$ & 25.6 & 3.5 & 0 \\
\hline \multirow[t]{4}{*}{$7 a$} & 1 & $5 / 20 / 2020$ & 11.7 & 1 & 1 & $17 \mathrm{a}$ & 1 & $5 / 18 / 2020$ & 13.3 & 0.1 & 2 \\
\hline & 2 & 6/9/2020 & 18.3 & 2 & 0 & & 2 & $6 / 10 / 2020$ & 17.2 & 3 & 0 \\
\hline & 3 & $7 / 12 / 2020$ & 21.7 & 2 & 0 & & 3 & $7 / 9 / 2020$ & 24.4 & 1 & 1 \\
\hline & 4 & $7 / 31 / 2020$ & 20.6 & 3 & 0 & & 4 & $7 / 27 / 2020$ & 26.7 & 3.5 & 1 \\
\hline \multirow[t]{4}{*}{$8 a$} & 1 & $5 / 22 / 2020$ & 21.1 & 1 & 2 & $18 \mathrm{a}$ & 1 & $5 / 18 / 2020$ & 15.0 & 2 & 2 \\
\hline & 2 & $6 / 13 / 2020$ & 15.6 & 3 & 1 & & 2 & $6 / 10 / 2020$ & 18.3 & 3 & 0 \\
\hline & 3 & $7 / 9 / 2020$ & 22.2 & 0 & 0 & & 3 & $7 / 9 / 2020$ & 25.6 & 2 & 1 \\
\hline & 4 & $7 / 31 / 2020$ & 26.1 & 2 & 1 & & 4 & $7 / 31 / 2020$ & 24.4 & 3.5 & 1 \\
\hline \multirow[t]{4}{*}{$9 a$} & 1 & $5 / 24 / 2020$ & 15.6 & 2 & 2 & $19 a$ & 1 & $5 / 18 / 2020$ & 15.0 & 0.2 & 2 \\
\hline & 2 & $6 / 13 / 2020$ & 15.0 & 3.5 & 1 & & 2 & $6 / 10 / 2020$ & 18.3 & 3 & 0 \\
\hline & 3 & $7 / 9 / 2020$ & 23.3 & 0 & 0 & & 3 & $7 / 12 / 2020$ & 26.1 & 4 & 0 \\
\hline & 4 & $7 / 31 / 2020$ & 20.6 & 3 & 0 & & 4 & $7 / 27 / 2020$ & 27.8 & 3.5 & 1 \\
\hline \multirow[t]{4}{*}{$10 \mathrm{a}$} & 1 & $5 / 22 / 2020$ & 20.0 & 2 & 2 & $20 \mathrm{a}$ & 1 & $5 / 24 / 2020$ & 18.3 & 2 & 1 \\
\hline & 2 & $6 / 9 / 2020$ & 19.4 & 3 & 0 & & 2 & $6 / 9 / 2020$ & 21.1 & 3 & 0 \\
\hline & 3 & $7 / 9 / 2020$ & 23.3 & 0 & 0 & & 3 & $7 / 12 / 2020$ & 26.7 & 4 & 1 \\
\hline & 4 & $7 / 31 / 2020$ & 20.6 & 3 & 0 & & 4 & $7 / 31 / 2020$ & 24.4 & 3.5 & 1 \\
\hline
\end{tabular}




\begin{tabular}{|c|c|c|c|c|c|c|c|c|c|c|c|}
\hline \multirow[t]{4}{*}{$21 \mathrm{a}$} & 1 & $5 / 20 / 2020$ & 13.3 & 5 & 1 & $31 \mathrm{a}$ & 1 & $5 / 18 / 2020$ & 18.3 & 1.2 & 2 \\
\hline & 2 & 6/9/2020 & 23.9 & 2 & 0 & & 2 & $6 / 11 / 2020$ & 21.7 & 3 & 1 \\
\hline & 3 & $7 / 12 / 2020$ & 26.7 & 2 & 1 & & 3 & $7 / 13 / 2020$ & 22.2 & 2 & 1 \\
\hline & 4 & $7 / 31 / 2020$ & 25.0 & 3.5 & 1 & & 4 & $7 / 29 / 2020$ & 27.8 & 4.5 & 1 \\
\hline \multirow[t]{4}{*}{$22 \mathrm{a}$} & 1 & $5 / 24 / 2020$ & 21.1 & 4 & 1 & $32 \mathrm{a}$ & 1 & $5 / 18 / 2020$ & 17.8 & 0 & 2 \\
\hline & 2 & $6 / 13 / 2020$ & 10.6 & 1 & 1 & & 2 & $6 / 11 / 2020$ & 21.1 & 3 & 1 \\
\hline & 3 & $7 / 9 / 2020$ & 26.1 & 2 & 1 & & 3 & $7 / 13 / 2020$ & 21.7 & 2 & 0 \\
\hline & 4 & $7 / 31 / 2020$ & 25.0 & 3.5 & 1 & & 4 & $7 / 29 / 2020$ & 27.2 & 4 & 1 \\
\hline \multirow[t]{4}{*}{$23 \mathrm{a}$} & 1 & $5 / 24 / 2020$ & 21.1 & 4 & 1 & $33 a$ & 1 & $5 / 22 / 2020$ & 17.2 & 2 & 2 \\
\hline & 2 & $6 / 13 / 2020$ & 11.1 & 3 & 1 & & 2 & $6 / 11 / 2020$ & 21.1 & 4 & 1 \\
\hline & 3 & $7 / 9 / 2020$ & 26.1 & 2 & 1 & & 3 & $7 / 13 / 2020$ & 21.7 & 2 & 0 \\
\hline & 4 & $7 / 31 / 2020$ & 25.0 & 3 & 1 & & 4 & $7 / 29 / 2020$ & 26.7 & 4 & 1 \\
\hline \multirow[t]{4}{*}{$24 \mathrm{a}$} & 1 & $5 / 24 / 2020$ & 23.3 & 3 & 1 & $34 \mathrm{a}$ & 1 & $5 / 22 / 2020$ & 17.2 & 2 & 2 \\
\hline & 2 & $6 / 8 / 2020$ & 20.0 & 3 & 1 & & 2 & $6 / 11 / 2020$ & 21.7 & 3 & 1 \\
\hline & 3 & $7 / 12 / 2020$ & 26.7 & 2 & 1 & & 3 & $7 / 13 / 2020$ & 22.8 & 2 & 1 \\
\hline & 4 & $7 / 27 / 2020$ & 28.9 & 4 & 1 & & 4 & $7 / 29 / 2020$ & 27.8 & 5 & 1 \\
\hline \multirow[t]{4}{*}{$25 \mathrm{a}$} & 1 & $5 / 24 / 2020$ & 22.2 & 4 & 1 & $35 a$ & 1 & $5 / 18 / 2020$ & 18.3 & 1.2 & 2 \\
\hline & 2 & $6 / 8 / 2020$ & 20.6 & 2.5 & 0 & & 2 & $6 / 11 / 2020$ & 22.8 & 3 & 1 \\
\hline & 3 & $7 / 9 / 2020$ & 27.2 & 3.5 & 1 & & 3 & $7 / 13 / 2020$ & 23.3 & 2 & 1 \\
\hline & 4 & $7 / 27 / 2020$ & 28.9 & 4 & 1 & & 4 & $7 / 29 / 2020$ & 27.8 & 5 & 1 \\
\hline \multirow[t]{4}{*}{$26 \mathrm{a}$} & 1 & $5 / 20 / 2020$ & 17.8 & 3 & 1 & $36 a$ & 1 & $5 / 22 / 2020$ & 17.2 & 2 & 2 \\
\hline & 2 & $6 / 9 / 2020$ & 24.4 & 2.5 & 0 & & 2 & $6 / 11 / 2020$ & 22.2 & 5 & 1 \\
\hline & 3 & $7 / 12 / 2020$ & 28.9 & 3 & 1 & & 3 & $7 / 13 / 2020$ & 23.3 & 2 & 1 \\
\hline & 4 & $7 / 27 / 2020$ & 29.4 & 4 & 1 & & 4 & $7 / 29 / 2020$ & 23.9 & 4 & 1 \\
\hline \multirow[t]{4}{*}{$27 \mathrm{a}$} & 1 & $5 / 20 / 2020$ & 16.7 & 4 & 1 & $37 \mathrm{a}$ & 1 & $5 / 22 / 2020$ & 18.9 & 2 & 2 \\
\hline & 2 & $6 / 9 / 2020$ & 26.1 & 3 & 0 & & 2 & $6 / 11 / 2020$ & 22.2 & 5 & 1 \\
\hline & 3 & $7 / 12 / 2020$ & 29.4 & 2 & 1 & & 3 & $7 / 13 / 2020$ & 23.9 & 6 & 1 \\
\hline & 4 & $7 / 27 / 2020$ & 30.6 & 4 & 1 & & 4 & $7 / 29 / 2020$ & 22.2 & 2 & 0 \\
\hline \multirow[t]{4}{*}{$28 \mathrm{a}$} & 1 & $5 / 20 / 2020$ & 17.8 & 4 & 1 & $38 \mathrm{a}$ & 1 & $5 / 18 / 2020$ & 18.9 & 2.1 & 2 \\
\hline & 2 & $6 / 9 / 2020$ & 27.8 & 3 & 0 & & 2 & $6 / 11 / 2020$ & 22.2 & 5 & 1 \\
\hline & 3 & $7 / 9 / 2020$ & 28.9 & 2.5 & 1 & & 3 & $7 / 13 / 2020$ & 23.9 & 3 & 1 \\
\hline & 4 & $7 / 27 / 2020$ & 31.1 & 4 & 1 & & 4 & $7 / 29 / 2020$ & 22.2 & 2 & 0 \\
\hline \multirow[t]{4}{*}{$29 a$} & 1 & $5 / 20 / 2020$ & 17.8 & 4 & 1 & $39 a$ & 1 & $5 / 18 / 2020$ & 18.9 & 2.5 & 2 \\
\hline & 2 & $6 / 9 / 2020$ & 28.9 & 3 & 0 & & 2 & $6 / 11 / 2020$ & 22.2 & 5 & 1 \\
\hline & 3 & $7 / 9 / 2020$ & 29.4 & 3 & 1 & & 3 & $7 / 13 / 2020$ & 26.1 & 2 & 1 \\
\hline & 4 & $7 / 27 / 2020$ & 32.8 & 4 & 1 & & 4 & $7 / 29 / 2020$ & 21.1 & 2.5 & 0 \\
\hline \multirow[t]{4}{*}{$30 \mathrm{a}$} & 1 & $5 / 20 / 2020$ & 17.8 & 4 & 1 & $40 a$ & 1 & $5 / 22 / 2020$ & 19.4 & 1 & 2 \\
\hline & 2 & $6 / 9 / 2020$ & 28.9 & 3 & 0 & & 2 & $6 / 11 / 2020$ & 23.3 & 4.5 & 1 \\
\hline & 3 & $7 / 9 / 2020$ & 28.9 & 2 & 1 & & 3 & $7 / 13 / 2020$ & 26.1 & 2 & 1 \\
\hline & 4 & $7 / 31 / 2020$ & 26.1 & 2 & 1 & & 4 & $7 / 29 / 2020$ & 20.6 & 1 & 0 \\
\hline $1 \mathrm{~b}$ & 1 & $5 / 25 / 2020$ & 15.6 & 0 & 2 & $11 \mathrm{~b}$ & 1 & $5 / 21 / 2020$ & 15.6 & 1 & 0 \\
\hline
\end{tabular}




\begin{tabular}{|c|c|c|c|c|c|c|c|c|c|c|c|}
\hline & 2 & $6 / 12 / 2020$ & 22.2 & 2 & 0 & & 2 & $6 / 14 / 2020$ & 15.0 & 2 & 0 \\
\hline \multirow{5}{*}{$2 b$} & 3 & $7 / 14 / 2020$ & 17.8 & 1 & 0 & & 3 & $7 / 14 / 2020$ & 25.0 & 2 & 1 \\
\hline & 4 & $8 / 1 / 2020$ & 16.7 & 0 & 1 & & 4 & $8 / 1 / 2020$ & 23.3 & 1 & 1 \\
\hline & 1 & $5 / 21 / 2020$ & 10.0 & 2 & 0 & $12 b$ & 1 & $5 / 19 / 2020$ & 15.6 & 3.1 & 1 \\
\hline & 2 & $6 / 12 / 2020$ & 21.7 & 1.5 & 0 & & 2 & $6 / 14 / 2020$ & 11.1 & 2 & 0 \\
\hline & 3 & $7 / 14 / 2020$ & 16.7 & 2.5 & 0 & & 3 & $7 / 14 / 2020$ & 17.8 & 2.5 & 0 \\
\hline \multirow{3}{*}{$3 b$} & 4 & $8 / 1 / 2020$ & 17.2 & 0 & 1 & & 4 & $8 / 1 / 2020$ & 17.8 & 0 & 1 \\
\hline & 1 & $5 / 25 / 2020$ & 15.0 & 0 & 2 & $13 b$ & 1 & $5 / 19 / 2020$ & 16.1 & 2 & 1 \\
\hline & 2 & $6 / 14 / 2020$ & 12.2 & 2 & 0 & & 2 & $6 / 12 / 2020$ & 21.1 & 1 & 0 \\
\hline \multirow{5}{*}{$4 b$} & 3 & $7 / 14 / 2020$ & 17.2 & 2.5 & 0 & & 3 & $7 / 10 / 2020$ & 26.1 & 2.5 & 1 \\
\hline & 4 & $8 / 1 / 2020$ & 17.2 & 0 & 1 & & 4 & $7 / 28 / 2020$ & 22.2 & 2 & 1 \\
\hline & 1 & $5 / 19 / 2020$ & 14.4 & 3.2 & 1 & $14 b$ & 1 & $5 / 21 / 2020$ & 13.3 & 2 & 0 \\
\hline & 2 & $6 / 14 / 2020$ & 10.0 & 2 & 0 & & 2 & $6 / 12 / 2020$ & 22.2 & 2 & 1 \\
\hline & 3 & $7 / 10 / 2020$ & 28.3 & 3 & 2 & & 3 & $7 / 14 / 2020$ & 23.9 & 2 & 1 \\
\hline \multirow{3}{*}{$5 b$} & 4 & $7 / 28 / 2020$ & 21.1 & 2 & 2 & & 4 & $8 / 1 / 2020$ & 23.9 & 0 & 1 \\
\hline & 1 & $5 / 19 / 2020$ & 15.0 & 3.4 & 1 & $17 \mathrm{~b}$ & 1 & $5 / 23 / 2020$ & 25.0 & 5 & 1 \\
\hline & 2 & $6 / 12 / 2020$ & 20.0 & 1.5 & 0 & & 2 & $6 / 10 / 2020$ & 30.0 & 3 & 2 \\
\hline \multirow{5}{*}{$6 b$} & 3 & $7 / 10 / 2020$ & 28.9 & 3 & 2 & & 3 & $7 / 11 / 2020$ & 25.6 & 4 & 1 \\
\hline & 4 & $7 / 28 / 2020$ & 21.1 & 2 & 1 & & 4 & $7 / 30 / 2020$ & 23.9 & 0 & 2 \\
\hline & 1 & $5 / 25 / 2020$ & 16.1 & 0 & 2 & $18 \mathrm{~b}$ & 1 & $5 / 23 / 2020$ & 26.1 & 5 & 1 \\
\hline & 2 & $6 / 12 / 2020$ & 20.0 & 1.5 & 0 & & 2 & $6 / 10 / 2020$ & 31.1 & 4 & 2 \\
\hline & 3 & $7 / 10 / 2020$ & 26.1 & 2.5 & 2 & & 3 & $7 / 11 / 2020$ & 26.1 & 4 & 2 \\
\hline \multirow{3}{*}{$7 b$} & 4 & $7 / 28 / 2020$ & 21.1 & 2 & 2 & & 4 & $7 / 30 / 2020$ & 23.9 & 0 & 1 \\
\hline & 1 & $5 / 25 / 2020$ & 16.7 & 0 & 2 & $19 b$ & 1 & $5 / 23 / 2020$ & 23.9 & 5 & 1 \\
\hline & 2 & $6 / 12 / 2020$ & 22.8 & 2 & 1 & & 2 & $6 / 10 / 2020$ & 27.8 & 1.5 & 1 \\
\hline \multirow{5}{*}{$8 b$} & 3 & $7 / 14 / 2020$ & 21.7 & 1.5 & 0 & & 3 & $7 / 11 / 2020$ & 24.4 & 0 & 2 \\
\hline & 4 & $8 / 1 / 2020$ & 22.8 & 2 & 1 & & 4 & $7 / 30 / 2020$ & 22.8 & 0 & 2 \\
\hline & 1 & $5 / 25 / 2020$ & 18.3 & 0 & 2 & $20 \mathrm{~b}$ & 1 & $5 / 23 / 2020$ & 26.7 & 4 & 1 \\
\hline & 2 & $6 / 14 / 2020$ & 12.8 & 3 & 0 & & 2 & $6 / 10 / 2020$ & 30.0 & 2 & 1 \\
\hline & 3 & $7 / 14 / 2020$ & 22.8 & 2.5 & 1 & & 3 & $7 / 11 / 2020$ & 26.1 & 4 & 1 \\
\hline \multirow{3}{*}{$9 b$} & 4 & $8 / 1 / 2020$ & 22.8 & 1 & 1 & & 4 & $7 / 30 / 2020$ & 24.4 & 0 & 1 \\
\hline & 1 & $5 / 21 / 2020$ & 12.8 & 2 & 0 & $21 b$ & 1 & $5 / 23 / 2020$ & 24.4 & 1 & 1 \\
\hline & 2 & $6 / 14 / 2020$ & 13.3 & 2 & 0 & & 2 & $6 / 10 / 2020$ & 26.7 & 1.5 & 1 \\
\hline \multirow{5}{*}{$10 \mathrm{~b}$} & 3 & $7 / 14 / 2020$ & 23.3 & 1 & 1 & & 3 & $7 / 11 / 2020$ & 21.1 & 0 & 1 \\
\hline & 4 & $8 / 1 / 2020$ & 23.9 & 0 & 1 & & 4 & $7 / 30 / 2020$ & 21.7 & 0 & 2 \\
\hline & 1 & $5 / 21 / 2020$ & 15.0 & 1.5 & 0 & $22 b$ & 1 & $5 / 23 / 2020$ & 18.9 & 0 & 2 \\
\hline & 2 & $6 / 12 / 2020$ & 25.0 & 3 & 1 & & 2 & $6 / 12 / 2020$ & 23.9 & 3 & 1 \\
\hline & 3 & $7 / 14 / 2020$ & 23.9 & 2 & 1 & & 3 & $7 / 11 / 2020$ & 23.9 & 3 & 1 \\
\hline \multirow{3}{*}{$23 b$} & 4 & $8 / 1 / 2020$ & 23.3 & 1 & 1 & & 4 & $7 / 30 / 2020$ & 24.4 & 1 & 2 \\
\hline & 1 & $5 / 21 / 2020$ & 18.3 & 1.5 & 0 & $33 b$ & 1 & $5 / 19 / 2020$ & 19.4 & 4 & 1 \\
\hline & 2 & $6 / 12 / 2020$ & 23.3 & 3 & 1 & & 2 & $6 / 10 / 2020$ & 26.1 & 5 & 2 \\
\hline
\end{tabular}




\begin{tabular}{|c|c|c|c|c|c|c|c|c|c|c|c|}
\hline & 3 & $7 / 11 / 2020$ & 22.2 & 1 & 1 & & 3 & $7 / 10 / 2020$ & 21.7 & 1 & 2 \\
\hline & 4 & $7 / 30 / 2020$ & 24.4 & 1 & 2 & & 4 & $7 / 28 / 2020$ & 23.9 & 2.5 & 1 \\
\hline \multirow[t]{4}{*}{$24 b$} & 1 & $5 / 23 / 2020$ & 21.1 & 1 & 2 & $34 \mathrm{~b}$ & 1 & $5 / 19 / 2020$ & 19.4 & 5 & 1 \\
\hline & 2 & $6 / 10 / 2020$ & 22.8 & 1.5 & 1 & & 2 & $6 / 10 / 2020$ & 26.7 & 2 & 2 \\
\hline & 3 & $7 / 11 / 2020$ & 23.3 & 1 & 1 & & 3 & $7 / 10 / 2020$ & 22.8 & 1 & 2 \\
\hline & 4 & $7 / 30 / 2020$ & 21.1 & 0 & 2 & & 4 & $7 / 27 / 2020$ & 24.4 & 2.5 & 1 \\
\hline \multirow[t]{4}{*}{$25 b$} & 1 & $5 / 23 / 2020$ & 22.2 & 1 & 1 & $35 b$ & 1 & $5 / 21 / 2020$ & 18.3 & 1 & 0 \\
\hline & 2 & $6 / 10 / 2020$ & 23.3 & 1.5 & 1 & & 2 & $6 / 14 / 2020$ & 18.9 & 2 & 1 \\
\hline & 3 & $7 / 11 / 2020$ & 23.3 & 1 & 1 & & 3 & $7 / 11 / 2020$ & 23.9 & 3 & 1 \\
\hline & 4 & $7 / 30 / 2020$ & 21.1 & 0 & 2 & & 4 & $7 / 28 / 2020$ & 24.4 & 2 & 1 \\
\hline \multirow[t]{4}{*}{$26 b$} & 1 & $5 / 23 / 2020$ & 23.3 & 2 & 1 & $36 \mathrm{~b}$ & 1 & $5 / 21 / 2020$ & 18.3 & 2 & 0 \\
\hline & 2 & $6 / 10 / 2020$ & 28.3 & 1.5 & 1 & & 2 & $6 / 14 / 2020$ & 17.8 & 2 & 1 \\
\hline & 3 & $7 / 11 / 2020$ & 21.1 & 0 & 1 & & 3 & $7 / 10 / 2020$ & 25.6 & 1 & 2 \\
\hline & 4 & $7 / 30 / 2020$ & 21.7 & 0 & 2 & & 4 & $7 / 28 / 2020$ & 24.4 & 2 & 1 \\
\hline \multirow[t]{4}{*}{$27 b$} & 1 & $5 / 23 / 2020$ & 19.4 & 0 & 2 & $37 b$ & 1 & $5 / 23 / 2020$ & 18.9 & 0 & 1 \\
\hline & 2 & $6 / 12 / 2020$ & 22.8 & 3 & 1 & & 2 & $6 / 10 / 2020$ & 26.7 & 5 & 1 \\
\hline & 3 & $7 / 11 / 2020$ & 25.6 & 4 & 1 & & 3 & $7 / 10 / 2020$ & 26.1 & 1 & 2 \\
\hline & 4 & $7 / 30 / 2020$ & 24.4 & 1 & 2 & & 4 & $7 / 28 / 2020$ & 23.9 & 0 & 1 \\
\hline \multirow[t]{4}{*}{$28 b$} & 1 & $5 / 19 / 2020$ & 16.1 & 4 & 1 & $38 b$ & 1 & $5 / 19 / 2020$ & 20.0 & 5 & 1 \\
\hline & 2 & $6 / 12 / 2020$ & 22.8 & 3 & 1 & & 2 & $6 / 10 / 2020$ & 27.8 & 2 & 1 \\
\hline & 3 & $7 / 10 / 2020$ & 26.7 & 3 & 1 & & 3 & $7 / 10 / 2020$ & 26.1 & 3 & 2 \\
\hline & 4 & $7 / 28 / 2020$ & 24.4 & 2 & 1 & & 4 & $7 / 28 / 2020$ & 24.4 & 1 & 1 \\
\hline \multirow[t]{4}{*}{$29 b$} & 1 & $5 / 19 / 2020$ & 16.1 & 4 & 1 & $39 b$ & 1 & $5 / 21 / 2020$ & 21.7 & 3 & 0 \\
\hline & 2 & $6 / 12 / 2020$ & 22.8 & 3 & 1 & & 2 & $6 / 13 / 2020$ & 19.4 & 2 & 1 \\
\hline & 3 & $7 / 10 / 2020$ & 26.7 & 3 & 1 & & 3 & $7 / 11 / 2020$ & 23.9 & 3 & 1 \\
\hline & 4 & $7 / 28 / 2020$ & 24.4 & 2 & 1 & & 4 & $7 / 28 / 2020$ & 25.0 & 2 & 1 \\
\hline \multirow[t]{4}{*}{$30 \mathrm{~b}$} & 1 & $5 / 23 / 2020$ & 20.6 & 1 & 2 & $40 \mathrm{~b}$ & 1 & $5 / 23 / 2020$ & 17.8 & 0 & 3 \\
\hline & 2 & $6 / 10 / 2020$ & 22.2 & 1.5 & 1 & & 2 & $6 / 10 / 2020$ & 27.8 & 2 & 1 \\
\hline & 3 & $7 / 11 / 2020$ & 22.2 & 1 & 1 & & 3 & $7 / 10 / 2020$ & 27.2 & 2 & 1 \\
\hline & 4 & $7 / 20 / 2020$ & 21.1 & 0 & 2 & & 4 & $7 / 28 / 2020$ & 25.6 & 1 & 1 \\
\hline \multirow[t]{4}{*}{$31 b$} & 1 & $5 / 23 / 2020$ & 20.0 & 1 & 2 & $41 b$ & 1 & $5 / 23 / 2020$ & 17.8 & 0 & 3 \\
\hline & 2 & $6 / 14 / 2020$ & 14.4 & 2 & 1 & & 2 & $6 / 13 / 2020$ & 18.9 & 3 & 1 \\
\hline & 3 & $7 / 10 / 2020$ & 22.8 & 1 & 2 & & 3 & $7 / 10 / 2020$ & 27.2 & 2 & 1 \\
\hline & 4 & $7 / 30 / 2020$ & 25.0 & 1 & 2 & & 4 & $7 / 28 / 2020$ & 26.1 & 2.5 & 1 \\
\hline \multirow[t]{4}{*}{$32 b$} & 1 & $5 / 19 / 2020$ & 18.9 & 5 & 1 & $42 b$ & 1 & $5 / 21 / 2020$ & 18.3 & 1 & 0 \\
\hline & 2 & $6 / 14 / 2020$ & 15.0 & 2 & 1 & & 2 & $6 / 13 / 2020$ & 20.6 & 2 & 1 \\
\hline & 3 & $7 / 11 / 2020$ & 26.1 & 3 & 3 & & 3 & $7 / 10 / 2020$ & 27.2 & 2 & 1 \\
\hline & 4 & $7 / 30 / 2020$ & 24.4 & 1 & 1 & & 4 & $7 / 28 / 2020$ & 26.7 & 1 & 1 \\
\hline
\end{tabular}


Appendix D: Coverboard encounters. For each encountered individual, the site, location, and board type is shown, in addition to the species. Data are organized by species.

\begin{tabular}{|c|c|c|c|c|}
\hline Site & Date & Location & Board Type & Species \\
\hline $10 \mathrm{~A}$ & $5 / 22 / 2020$ & $10 \mathrm{~m}$ & Plywood & Diadophis punctatus \\
\hline $33 B$ & $7 / 28 / 2020$ & $30 \mathrm{~m}$ & Plywood & Diadophis punctatus \\
\hline $18 \mathrm{~B}$ & $6 / 10 / 2020$ & Edge & Array & Diadophis punctatus \\
\hline $41 B$ & $6 / 13 / 2020$ & Edge & Plywood & Diadophis punctatus \\
\hline $9 \mathrm{~B}$ & $6 / 14 / 2020$ & Edge & Plywood & Diadophis punctatus \\
\hline $13 \mathrm{~A}$ & $7 / 9 / 2020$ & ROW & Plywood & Diadophis punctatus \\
\hline $25 B$ & $7 / 30 / 2020$ & ROW & Plywood & Diadophis punctatus \\
\hline $30 \mathrm{~B}$ & $6 / 10 / 2020$ & ROW & Array & Diadophis punctatus \\
\hline $7 \mathrm{~B}$ & $6 / 12 / 2020$ & Edge & Array & Lampropeltis triangulum \\
\hline $38 \mathrm{~B}$ & $5 / 19 / 2020$ & Edge & Plywood & Microtus pennsylvanicus \\
\hline $7 \mathrm{~A}$ & $5 / 20 / 2020$ & Edge & Plywood & Microtus pennsylvanicus \\
\hline $39 \mathrm{~A}$ & $6 / 11 / 2020$ & Edge & Plywood & Microtus pennsylvanicus \\
\hline $7 \mathrm{~A}$ & $7 / 31 / 2020$ & Edge & Plywood & Microtus pennsylvanicus \\
\hline $21 \mathrm{~A}$ & $7 / 31 / 2020$ & Edge & Plywood & Microtus pennsylvanicus \\
\hline $39 \mathrm{~A}$ & $7 / 29 / 2020$ & Edge & Plywood & Microtus pennsylvanicus \\
\hline $2 \mathrm{~A}$ & $7 / 29 / 2020$ & Edge & Plywood & Microtus pennsylvanicus \\
\hline $32 \mathrm{~A}$ & $5 / 18 / 2020$ & ROW & Plywood & Microtus pennsylvanicus \\
\hline $5 \mathrm{~B}$ & $5 / 19 / 2020$ & ROW & Plywood & Microtus pennsylvanicus \\
\hline $28 \mathrm{~B}$ & $5 / 19 / 2020$ & ROW & Plywood & Microtus pennsylvanicus \\
\hline $38 \mathrm{~B}$ & $5 / 19 / 2020$ & ROW & Plywood & Microtus pennsylvanicus \\
\hline $28 \mathrm{~A}$ & $5 / 20 / 2020$ & ROW & Plywood & Microtus pennsylvanicus \\
\hline $37 \mathrm{~A}$ & $5 / 22 / 2020$ & ROW & Plywood & Microtus pennsylvanicus \\
\hline $19 B$ & $5 / 23 / 2020$ & ROW & Plywood & Microtus pennsylvanicus \\
\hline $24 B$ & $5 / 23 / 2020$ & ROW & Plywood & Microtus pennsylvanicus \\
\hline $23 \mathrm{~A}$ & $5 / 24 / 2020$ & ROW & Plywood & Microtus pennsylvanicus \\
\hline $2 \mathrm{~A}$ & $6 / 11 / 2020$ & ROW & Plywood & Microtus pennsylvanicus \\
\hline $2 \mathrm{~A}$ & $6 / 11 / 2020$ & ROW & Plywood & Microtus pennsylvanicus \\
\hline $2 \mathrm{~A}$ & $6 / 11 / 2020$ & ROW & Plywood & Microtus pennsylvanicus \\
\hline $23 \mathrm{~B}$ & $6 / 12 / 2020$ & ROW & Plywood & Microtus pennsylvanicus \\
\hline $39 B$ & $6 / 13 / 2020$ & ROW & Plywood & Microtus pennsylvanicus \\
\hline $39 B$ & $6 / 13 / 2020$ & ROW & Plywood & Microtus pennsylvanicus \\
\hline $12 \mathrm{~A}$ & $7 / 12 / 2020$ & ROW & Plywood & Microtus pennsylvanicus \\
\hline $7 \mathrm{~A}$ & $7 / 12 / 2020$ & ROW & Plywood & Microtus pennsylvanicus \\
\hline $21 \mathrm{~B}$ & $7 / 11 / 2020$ & ROW & Plywood & Microtus pennsylvanicus \\
\hline $38 \mathrm{~B}$ & $7 / 10 / 2020$ & ROW & Plywood & Microtus pennsylvanicus \\
\hline $18 \mathrm{~A}$ & $7 / 31 / 2020$ & ROW & Plywood & Microtus pennsylvanicus \\
\hline $21 \mathrm{~A}$ & $7 / 31 / 2020$ & ROW & Plywood & Microtus pennsylvanicus \\
\hline
\end{tabular}




\begin{tabular}{|c|c|c|c|c|}
\hline $33 \mathrm{~A}$ & $7 / 29 / 2020$ & ROW & Plywood & Microtus pennsylvanicus \\
\hline $33 \mathrm{~A}$ & $7 / 29 / 2020$ & ROW & Array & Microtus pennsylvanicus \\
\hline $26 \mathrm{~A}$ & $7 / 27 / 2020$ & ROW & Plywood & Microtus pennsylvanicus \\
\hline $36 \mathrm{~B}$ & $7 / 28 / 2020$ & Edge & Plywood & Microtus pennsylvanicus \\
\hline $31 \mathrm{~A}$ & $5 / 18 / 2020$ & $30 \mathrm{~m}$ & Array & Nopthalmus Viridescens \\
\hline $1 \mathrm{~A}$ & $7 / 13 / 2020$ & $30 \mathrm{~m}$ & Array & Nopthalmus Viridescens \\
\hline $2 \mathrm{~A}$ & $7 / 13 / 2020$ & Edge & Array & Nopthalmus Viridescens \\
\hline $41 \mathrm{~B}$ & $7 / 10 / 2020$ & Edge & Array & Nopthalmus Viridescens \\
\hline 39B & $5 / 21 / 2020$ & ROW & Array & Nopthalmus Viridescens \\
\hline 39B & $5 / 21 / 2020$ & ROW & Array & Nopthalmus Viridescens \\
\hline $2 \mathrm{~A}$ & $6 / 11 / 2020$ & ROW & Array & Nopthalmus Viridescens \\
\hline $33 \mathrm{~A}$ & $7 / 13 / 2020$ & ROW & Array & Nopthalmus Viridescens \\
\hline $2 \mathrm{~A}$ & $7 / 13 / 2020$ & ROW & Array & Nopthalmus Viridescens \\
\hline $34 \mathrm{~B}$ & $6 / 10 / 2020$ & ROW & Plywood & Nopthalmus Viridescens \\
\hline $9 \mathrm{~A}$ & $6 / 13 / 2020$ & ROW & Plywood & Nopthalmus Viridescens \\
\hline $1 \mathrm{~A}$ & $7 / 13 / 2020$ & ROW & Plywood & Nopthalmus Viridescens \\
\hline $8 \mathrm{~A}$ & $7 / 9 / 2020$ & ROW & Plywood & Opheodrys vernalis \\
\hline 13B & $5 / 19 / 2020$ & $10 \mathrm{~m}$ & Array & Plethodon cinereus \\
\hline $14 \mathrm{~A}$ & $7 / 9 / 2020$ & $10 \mathrm{~m}$ & Array & Plethodon cinereus \\
\hline $16 \mathrm{~A}$ & $5 / 20 / 2020$ & $10 \mathrm{~m}$ & Array & Plethodon cinereus \\
\hline $16 \mathrm{~A}$ & $7 / 12 / 2020$ & $10 \mathrm{~m}$ & Array & Plethodon cinereus \\
\hline $16 \mathrm{~A}$ & $5 / 20 / 2020$ & $10 \mathrm{~m}$ & Plywood & Plethodon cinereus \\
\hline $18 \mathrm{~A}$ & $5 / 18 / 2020$ & $10 \mathrm{~m}$ & Plywood & Plethodon cinereus \\
\hline $18 \mathrm{~A}$ & $5 / 18 / 2020$ & $10 \mathrm{~m}$ & Plywood & Plethodon cinereus \\
\hline 19A & $5 / 18 / 2020$ & $10 \mathrm{~m}$ & Array & Plethodon cinereus \\
\hline 19B & $7 / 11 / 2020$ & $10 \mathrm{~m}$ & Array & Plethodon cinereus \\
\hline $20 \mathrm{~A}$ & $7 / 31 / 2020$ & $10 \mathrm{~m}$ & Array & Plethodon cinereus \\
\hline $20 \mathrm{~B}$ & $5 / 23 / 2020$ & $10 \mathrm{~m}$ & Array & Plethodon cinereus \\
\hline $21 \mathrm{~A}$ & $7 / 12 / 2020$ & $10 \mathrm{~m}$ & Array & Plethodon cinereus \\
\hline $21 \mathrm{~A}$ & $7 / 12 / 2020$ & $10 \mathrm{~m}$ & Plywood & Plethodon cinereus \\
\hline $22 \mathrm{~A}$ & $5 / 24 / 2020$ & $10 \mathrm{~m}$ & Plywood & Plethodon cinereus \\
\hline $23 \mathrm{~A}$ & $6 / 13 / 2020$ & $10 \mathrm{~m}$ & Array & Plethodon cinereus \\
\hline $24 \mathrm{~B}$ & $5 / 23 / 2020$ & $10 \mathrm{~m}$ & Array & Plethodon cinereus \\
\hline $25 \mathrm{~A}$ & $5 / 24 / 2020$ & $10 \mathrm{~m}$ & Array & Plethodon cinereus \\
\hline $26 \mathrm{~B}$ & $6 / 10 / 2020$ & $10 \mathrm{~m}$ & Array & Plethodon cinereus \\
\hline $29 \mathrm{~A}$ & $5 / 20 / 2020$ & $10 \mathrm{~m}$ & Array & Plethodon cinereus \\
\hline $29 \mathrm{~A}$ & $5 / 20 / 2020$ & $10 \mathrm{~m}$ & Array & Plethodon cinereus \\
\hline $2 \mathrm{~A}$ & $6 / 11 / 2020$ & $10 \mathrm{~m}$ & Array & Plethodon cinereus \\
\hline $2 \mathrm{~A}$ & $6 / 11 / 2020$ & $10 \mathrm{~m}$ & Array & Plethodon cinereus \\
\hline $30 \mathrm{~A}$ & $5 / 20 / 2020$ & $10 \mathrm{~m}$ & Array & Plethodon cinereus \\
\hline $30 \mathrm{~A}$ & $5 / 20 / 2020$ & $10 \mathrm{~m}$ & Array & Plethodon cinereus \\
\hline
\end{tabular}




\begin{tabular}{|c|c|c|c|c|}
\hline $30 \mathrm{~A}$ & $5 / 20 / 2020$ & $10 \mathrm{~m}$ & Array & Plethodon cinereus \\
\hline $30 \mathrm{~A}$ & $5 / 20 / 2020$ & $10 \mathrm{~m}$ & Array & Plethodon cinereus \\
\hline $30 \mathrm{~A}$ & $5 / 20 / 2020$ & $10 \mathrm{~m}$ & Array & Plethodon cinereus \\
\hline $32 \mathrm{~A}$ & $5 / 18 / 2020$ & $10 \mathrm{~m}$ & Array & Plethodon cinereus \\
\hline $32 \mathrm{~A}$ & $7 / 13 / 2020$ & $10 \mathrm{~m}$ & Array & Plethodon cinereus \\
\hline $34 \mathrm{~A}$ & $5 / 22 / 2020$ & $10 \mathrm{~m}$ & Array & Plethodon cinereus \\
\hline $34 \mathrm{~A}$ & $5 / 22 / 2020$ & $10 \mathrm{~m}$ & Array & Plethodon cinereus \\
\hline $34 \mathrm{~A}$ & $5 / 22 / 2020$ & $10 \mathrm{~m}$ & Array & Plethodon cinereus \\
\hline $34 \mathrm{~B}$ & $5 / 19 / 2020$ & $10 \mathrm{~m}$ & Array & Plethodon cinereus \\
\hline $34 \mathrm{~B}$ & $5 / 19 / 2020$ & $10 \mathrm{~m}$ & Plywood & Plethodon cinereus \\
\hline $35 \mathrm{~A}$ & $6 / 11 / 2020$ & $10 \mathrm{~m}$ & Array & Plethodon cinereus \\
\hline $37 \mathrm{~B}$ & $5 / 23 / 2020$ & $10 \mathrm{~m}$ & Plywood & Plethodon cinereus \\
\hline $4 B$ & $6 / 14 / 2020$ & $10 \mathrm{~m}$ & Array & Plethodon cinereus \\
\hline $4 B$ & $6 / 14 / 2020$ & $10 \mathrm{~m}$ & Array & Plethodon cinereus \\
\hline $5 \mathrm{~A}$ & $7 / 12 / 2020$ & $10 \mathrm{~m}$ & Array & Plethodon cinereus \\
\hline $6 \mathrm{~A}$ & $5 / 20 / 2020$ & $10 \mathrm{~m}$ & Array & Plethodon cinereus \\
\hline $6 \mathrm{~A}$ & $6 / 8 / 2020$ & $10 \mathrm{~m}$ & Array & Plethodon cinereus \\
\hline $6 \mathrm{~A}$ & $5 / 20 / 2020$ & $10 \mathrm{~m}$ & Plywood & Plethodon cinereus \\
\hline $6 \mathrm{~A}$ & $6 / 8 / 2020$ & $10 \mathrm{~m}$ & Plywood & Plethodon cinereus \\
\hline $7 \mathrm{~A}$ & $7 / 31 / 2020$ & $10 \mathrm{~m}$ & Array & Plethodon cinereus \\
\hline $8 B$ & $7 / 14 / 2020$ & $10 \mathrm{~m}$ & Array & Plethodon cinereus \\
\hline $9 \mathrm{~A}$ & $5 / 24 / 2020$ & $10 \mathrm{~m}$ & Array & Plethodon cinereus \\
\hline $9 \mathrm{~A}$ & $6 / 13 / 2020$ & $10 \mathrm{~m}$ & Array & Plethodon cinereus \\
\hline $10 \mathrm{~A}$ & $5 / 22 / 2020$ & $30 \mathrm{~m}$ & Array & Plethodon cinereus \\
\hline $10 \mathrm{~A}$ & $5 / 22 / 2020$ & $30 \mathrm{~m}$ & Array & Plethodon cinereus \\
\hline $10 \mathrm{~A}$ & $7 / 9 / 2020$ & $30 \mathrm{~m}$ & Array & Plethodon cinereus \\
\hline $11 \mathrm{~A}$ & $5 / 18 / 2020$ & $30 \mathrm{~m}$ & Plywood & Plethodon cinereus \\
\hline $12 \mathrm{~A}$ & $5 / 20 / 2020$ & $30 \mathrm{~m}$ & Plywood & Plethodon cinereus \\
\hline $13 \mathrm{~A}$ & $6 / 8 / 2020$ & $30 \mathrm{~m}$ & Array & Plethodon cinereus \\
\hline $13 \mathrm{~A}$ & $7 / 9 / 2020$ & $30 \mathrm{~m}$ & Array & Plethodon cinereus \\
\hline $14 \mathrm{~A}$ & $6 / 8 / 2020$ & $30 \mathrm{~m}$ & Array & Plethodon cinereus \\
\hline $14 \mathrm{~A}$ & $7 / 31 / 2020$ & $30 \mathrm{~m}$ & Array & Plethodon cinereus \\
\hline $16 \mathrm{~A}$ & $5 / 20 / 2020$ & $30 \mathrm{~m}$ & Array & Plethodon cinereus \\
\hline $16 \mathrm{~A}$ & $5 / 20 / 2020$ & $30 \mathrm{~m}$ & Array & Plethodon cinereus \\
\hline $16 \mathrm{~A}$ & $6 / 13 / 2020$ & $30 \mathrm{~m}$ & Array & Plethodon cinereus \\
\hline $16 \mathrm{~A}$ & $6 / 13 / 2020$ & $30 \mathrm{~m}$ & Array & Plethodon cinereus \\
\hline $18 \mathrm{~A}$ & $7 / 9 / 2020$ & $30 \mathrm{~m}$ & Array & Plethodon cinereus \\
\hline 18B & $6 / 10 / 2020$ & $30 \mathrm{~m}$ & Array & Plethodon cinereus \\
\hline 19A & $6 / 8 / 2020$ & $30 \mathrm{~m}$ & Array & Plethodon cinereus \\
\hline 19B & $5 / 23 / 2020$ & $30 \mathrm{~m}$ & Array & Plethodon cinereus \\
\hline 19B & $5 / 23 / 2020$ & $30 \mathrm{~m}$ & Array & Plethodon cinereus \\
\hline
\end{tabular}




\begin{tabular}{|c|c|c|c|c|}
\hline $1 \mathrm{~A}$ & $6 / 11 / 2020$ & $30 \mathrm{~m}$ & Array & Plethodon cinereus \\
\hline $20 \mathrm{~A}$ & $7 / 31 / 2020$ & $30 \mathrm{~m}$ & Array & Plethodon cinereus \\
\hline $20 \mathrm{~A}$ & $6 / 9 / 2020$ & $30 \mathrm{~m}$ & Plywood & Plethodon cinereus \\
\hline $21 \mathrm{~A}$ & $6 / 9 / 2020$ & $30 \mathrm{~m}$ & Array & Plethodon cinereus \\
\hline $21 \mathrm{~A}$ & $7 / 12 / 2020$ & $30 \mathrm{~m}$ & Array & Plethodon cinereus \\
\hline $21 \mathrm{~A}$ & 20-May & $30 \mathrm{~m}$ & Plywood & Plethodon cinereus \\
\hline $21 \mathrm{~B}$ & $5 / 23 / 2020$ & $30 \mathrm{~m}$ & Array & Plethodon cinereus \\
\hline $22 \mathrm{~A}$ & $7 / 9 / 2020$ & $30 \mathrm{~m}$ & Array & Plethodon cinereus \\
\hline $22 \mathrm{~A}$ & $7 / 9 / 2020$ & $30 \mathrm{~m}$ & Array & Plethodon cinereus \\
\hline $22 \mathrm{~A}$ & $6 / 13 / 2020$ & $30 \mathrm{~m}$ & Plywood & Plethodon cinereus \\
\hline $22 \mathrm{~B}$ & $5 / 23 / 2020$ & $30 \mathrm{~m}$ & Array & Plethodon cinereus \\
\hline $25 \mathrm{~A}$ & $5 / 24 / 2020$ & $30 \mathrm{~m}$ & Array & Plethodon cinereus \\
\hline $25 \mathrm{~B}$ & $5 / 23 / 2020$ & $30 \mathrm{~m}$ & Array & Plethodon cinereus \\
\hline $26 \mathrm{~B}$ & $5 / 23 / 2020$ & $30 \mathrm{~m}$ & Array & Plethodon cinereus \\
\hline 27B & $5 / 23 / 2020$ & $30 \mathrm{~m}$ & Array & Plethodon cinereus \\
\hline $28 \mathrm{~A}$ & $5 / 20 / 2020$ & $30 \mathrm{~m}$ & Array & Plethodon cinereus \\
\hline $28 \mathrm{~A}$ & $5 / 20 / 2020$ & $30 \mathrm{~m}$ & Plywood & Plethodon cinereus \\
\hline $29 \mathrm{~A}$ & $5 / 20 / 2020$ & $30 \mathrm{~m}$ & Array & Plethodon cinereus \\
\hline $2 \mathrm{~A}$ & $5 / 18 / 2020$ & $30 \mathrm{~m}$ & Array & Plethodon cinereus \\
\hline $30 \mathrm{~A}$ & $5 / 20 / 2020$ & $30 \mathrm{~m}$ & Array & Plethodon cinereus \\
\hline $30 \mathrm{~A}$ & $5 / 20 / 2020$ & $30 \mathrm{~m}$ & Plywood & Plethodon cinereus \\
\hline $30 \mathrm{~B}$ & $5 / 23 / 2020$ & $30 \mathrm{~m}$ & Array & Plethodon cinereus \\
\hline 30B & $5 / 23 / 2020$ & $30 \mathrm{~m}$ & Array & Plethodon cinereus \\
\hline $31 \mathrm{~A}$ & $5 / 18 / 2020$ & $30 \mathrm{~m}$ & Array & Plethodon cinereus \\
\hline $31 \mathrm{~A}$ & $5 / 18 / 2020$ & $30 \mathrm{~m}$ & Array & Plethodon cinereus \\
\hline $32 \mathrm{~A}$ & $5 / 18 / 2020$ & $30 \mathrm{~m}$ & Array & Plethodon cinereus \\
\hline $32 \mathrm{~A}$ & $6 / 11 / 2020$ & $30 \mathrm{~m}$ & Array & Plethodon cinereus \\
\hline $32 \mathrm{~A}$ & $7 / 13 / 2020$ & $30 \mathrm{~m}$ & Plywood & Plethodon cinereus \\
\hline $32 \mathrm{~A}$ & $7 / 13 / 2020$ & $30 \mathrm{~m}$ & Plywood & Plethodon cinereus \\
\hline $32 \mathrm{~A}$ & $7 / 29 / 2020$ & $30 \mathrm{~m}$ & Plywood & Plethodon cinereus \\
\hline $34 \mathrm{~A}$ & $7 / 29 / 2020$ & $30 \mathrm{~m}$ & Array & Plethodon cinereus \\
\hline $34 \mathrm{~B}$ & $5 / 19 / 2020$ & $30 \mathrm{~m}$ & Array & Plethodon cinereus \\
\hline $34 \mathrm{~B}$ & $5 / 19 / 2020$ & $30 \mathrm{~m}$ & Array & Plethodon cinereus \\
\hline $34 \mathrm{~B}$ & $5 / 19 / 2020$ & $30 \mathrm{~m}$ & Array & Plethodon cinereus \\
\hline $35 \mathrm{~A}$ & $5 / 18 / 2020$ & $30 \mathrm{~m}$ & Array & Plethodon cinereus \\
\hline $35 \mathrm{~A}$ & $5 / 18 / 2020$ & $30 \mathrm{~m}$ & Plywood & Plethodon cinereus \\
\hline $35 \mathrm{~B}$ & $5 / 21 / 2020$ & $30 \mathrm{~m}$ & Array & Plethodon cinereus \\
\hline $39 \mathrm{~A}$ & $5 / 18 / 2020$ & $30 \mathrm{~m}$ & Array & Plethodon cinereus \\
\hline 39B & $5 / 21 / 2020$ & $30 \mathrm{~m}$ & Array & Plethodon cinereus \\
\hline $3 \mathrm{~A}$ & $5 / 22 / 2020$ & $30 \mathrm{~m}$ & Array & Plethodon cinereus \\
\hline $40 \mathrm{~A}$ & $5 / 22 / 2020$ & $30 \mathrm{~m}$ & Array & Plethodon cinereus \\
\hline
\end{tabular}




\begin{tabular}{|c|c|c|c|c|}
\hline $42 B$ & $5 / 21 / 2020$ & $30 \mathrm{~m}$ & Array & Plethodon cinereus \\
\hline $4 \mathrm{~B}$ & $5 / 19 / 2020$ & $30 \mathrm{~m}$ & Array & Plethodon cinereus \\
\hline $5 \mathrm{~A}$ & $5 / 22 / 2020$ & $30 \mathrm{~m}$ & Array & Plethodon cinereus \\
\hline $5 \mathrm{~A}$ & $6 / 13 / 2020$ & $30 \mathrm{~m}$ & Array & Plethodon cinereus \\
\hline $5 \mathrm{~A}$ & $7 / 12 / 2020$ & $30 \mathrm{~m}$ & Array & Plethodon cinereus \\
\hline $6 \mathrm{~A}$ & $5 / 20 / 2020$ & $30 \mathrm{~m}$ & Array & Plethodon cinereus \\
\hline $6 \mathrm{~A}$ & $6 / 8 / 2020$ & $30 \mathrm{~m}$ & Array & Plethodon cinereus \\
\hline $6 \mathrm{~A}$ & $7 / 12 / 2020$ & $30 \mathrm{~m}$ & Array & Plethodon cinereus \\
\hline $7 \mathrm{~A}$ & $5 / 20 / 2020$ & $30 \mathrm{~m}$ & Array & Plethodon cinereus \\
\hline $7 \mathrm{~A}$ & $5 / 20 / 2020$ & $30 \mathrm{~m}$ & Array & Plethodon cinereus \\
\hline $7 \mathrm{~A}$ & $7 / 12 / 2020$ & $30 \mathrm{~m}$ & Array & Plethodon cinereus \\
\hline $7 \mathrm{~A}$ & $5 / 20 / 2020$ & $30 \mathrm{~m}$ & Plywood & Plethodon cinereus \\
\hline $8 \mathrm{~A}$ & $7 / 9 / 2020$ & $30 \mathrm{~m}$ & Array & Plethodon cinereus \\
\hline $8 B$ & $5 / 24 / 2020$ & $30 \mathrm{~m}$ & Array & Plethodon cinereus \\
\hline $9 \mathrm{~A}$ & $7 / 31 / 2020$ & $30 \mathrm{~m}$ & Array & Plethodon cinereus \\
\hline $9 \mathrm{~A}$ & $7 / 31 / 2020$ & $30 \mathrm{~m}$ & Array & Plethodon cinereus \\
\hline 9B & $5 / 21 / 2020$ & $30 \mathrm{~m}$ & Array & Plethodon cinereus \\
\hline 9B & $6 / 14 / 2020$ & $30 \mathrm{~m}$ & Array & Plethodon cinereus \\
\hline $15 \mathrm{~A}$ & $6 / 8 / 2020$ & Edge & Array & Plethodon cinereus \\
\hline $16 \mathrm{~A}$ & $5 / 20 / 2020$ & Edge & Array & Plethodon cinereus \\
\hline $16 \mathrm{~A}$ & $6 / 13 / 2020$ & Edge & Array & Plethodon cinereus \\
\hline $16 \mathrm{~A}$ & $7 / 12 / 2020$ & Edge & Array & Plethodon cinereus \\
\hline $16 \mathrm{~A}$ & $5 / 20 / 2020$ & Edge & Plywood & Plethodon cinereus \\
\hline 19B & $5 / 23 / 2020$ & Edge & Array & Plethodon cinereus \\
\hline 19B & $6 / 10 / 2020$ & Edge & Array & Plethodon cinereus \\
\hline 19B & $6 / 10 / 2020$ & Edge & Array & Plethodon cinereus \\
\hline $21 \mathrm{~A}$ & $5 / 20 / 2020$ & Edge & Array & Plethodon cinereus \\
\hline $21 \mathrm{~A}$ & $6 / 9 / 2020$ & Edge & Array & Plethodon cinereus \\
\hline $21 \mathrm{~B}$ & $5 / 23 / 2020$ & Edge & Array & Plethodon cinereus \\
\hline $24 \mathrm{~A}$ & $6 / 8 / 2020$ & Edge & Array & Plethodon cinereus \\
\hline $25 \mathrm{~A}$ & $5 / 24 / 2020$ & Edge & Array & Plethodon cinereus \\
\hline $26 \mathrm{~B}$ & $5 / 23 / 2020$ & Edge & Array & Plethodon cinereus \\
\hline $27 \mathrm{~B}$ & $5 / 23 / 2020$ & Edge & Array & Plethodon cinereus \\
\hline $29 \mathrm{~A}$ & $7 / 9 / 2020$ & Edge & Array & Plethodon cinereus \\
\hline $2 \mathrm{~A}$ & $5 / 18 / 2020$ & Edge & Array & Plethodon cinereus \\
\hline $2 \mathrm{~A}$ & $5 / 18 / 2020$ & Edge & Array & Plethodon cinereus \\
\hline $32 \mathrm{~B}$ & $5 / 19 / 2020$ & Edge & Array & Plethodon cinereus \\
\hline $5 \mathrm{~A}$ & $5 / 22 / 2020$ & Edge & Array & Plethodon cinereus \\
\hline $7 \mathrm{~A}$ & $7 / 12 / 2020$ & Edge & Array & Plethodon cinereus \\
\hline $9 \mathrm{~A}$ & $5 / 24 / 2020$ & Edge & Array & Plethodon cinereus \\
\hline $9 \mathrm{~A}$ & $6 / 13 / 2020$ & Edge & Array & Plethodon cinereus \\
\hline
\end{tabular}




\begin{tabular}{|c|c|c|c|c|}
\hline $9 \mathrm{~A}$ & $7 / 9 / 2020$ & Edge & Array & Plethodon cinereus \\
\hline $24 B$ & $5 / 23 / 2020$ & Edge & Array & Plethodon cinereus \\
\hline $9 \mathrm{~B}$ & $5 / 21 / 2020$ & Edge & Array & Plethodon cinereus \\
\hline $17 \mathrm{~A}$ & $6 / 8 / 2020$ & ROW & Array & Plethodon cinereus \\
\hline $18 \mathrm{~A}$ & $5 / 18 / 2020$ & ROW & Array & Plethodon cinereus \\
\hline $19 \mathrm{~A}$ & $5 / 18 / 2020$ & ROW & Array & Plethodon cinereus \\
\hline $21 B$ & $5 / 23 / 2020$ & ROW & Array & Plethodon cinereus \\
\hline $22 \mathrm{~A}$ & $5 / 24 / 2020$ & ROW & Array & Plethodon cinereus \\
\hline $23 \mathrm{~A}$ & $5 / 24 / 2020$ & ROW & Array & Plethodon cinereus \\
\hline $26 \mathrm{~A}$ & $5 / 20 / 2020$ & ROW & Array & Plethodon cinereus \\
\hline $28 \mathrm{~A}$ & $5 / 20 / 2020$ & ROW & Array & Plethodon cinereus \\
\hline $30 \mathrm{~B}$ & $5 / 23 / 2020$ & ROW & Array & Plethodon cinereus \\
\hline $34 \mathrm{~A}$ & $5 / 22 / 2020$ & ROW & Array & Plethodon cinereus \\
\hline $35 \mathrm{~A}$ & $5 / 18 / 2020$ & ROW & Array & Plethodon cinereus \\
\hline $36 \mathrm{~B}$ & $5 / 21 / 2020$ & ROW & Array & Plethodon cinereus \\
\hline 39B & $5 / 21 / 2020$ & ROW & Array & Plethodon cinereus \\
\hline $8 \mathrm{~A}$ & $5 / 22 / 2020$ & ROW & Array & Plethodon cinereus \\
\hline $8 B$ & $5 / 24 / 2020$ & ROW & Array & Plethodon cinereus \\
\hline $8 B$ & $5 / 24 / 2020$ & ROW & Array & Plethodon cinereus \\
\hline $3 \mathrm{~A}$ & $6 / 11 / 2020$ & $30 \mathrm{~m}$ & Array & Plethodon glutinosus \\
\hline $22 \mathrm{~B}$ & $5 / 23 / 2020$ & $10 \mathrm{~m}$ & Plywood & Plethodon glutinosus \\
\hline $22 \mathrm{~B}$ & $5 / 23 / 2020$ & $30 \mathrm{~m}$ & Plywood & Plethodon glutinosus \\
\hline 21B & $7 / 11 / 2020$ & $30 \mathrm{~m}$ & Plywood & Plethodon glutinosus \\
\hline 21B & $7 / 30 / 2020$ & $30 \mathrm{~m}$ & Plywood & Plethodon glutinosus \\
\hline 24B & $7 / 30 / 2020$ & Edge & Array & Storeria dekayi \\
\hline $32 \mathrm{~A}$ & $6 / 11 / 2020$ & ROW & Array & Storeria dekayi \\
\hline $36 \mathrm{~A}$ & $6 / 11 / 2020$ & ROW & Plywood & Storeria dekayi \\
\hline $16 \mathrm{~A}$ & $7 / 27 / 2020$ & ROW & Plywood & Storeria occipitomaculata \\
\hline $26 \mathrm{~A}$ & $7 / 27 / 2020$ & ROW & Array & Storeria occipitomaculata \\
\hline $36 \mathrm{~B}$ & $7 / 28 / 2020$ & ROW & Plywood & Storeria occipitomaculata \\
\hline $35 \mathrm{~A}$ & $5 / 18 / 2020$ & $30 \mathrm{~m}$ & Plywood & Thamnophis sirtalis \\
\hline $36 \mathrm{~B}$ & 21-May & $30 \mathrm{~m}$ & Plywood & Thamnophis sirtalis \\
\hline $22 \mathrm{~A}$ & $7 / 9 / 2020$ & Edge & Plywood & Thamnophis sirtalis \\
\hline $4 \mathrm{~B}$ & $6 / 14 / 2020$ & Edge & Array & Thamnophis sirtalis \\
\hline $1 \mathrm{~A}$ & $6 / 11 / 2020$ & ROW & Plywood & Thamnophis sirtalis \\
\hline $25 \mathrm{~B}$ & $7 / 11 / 2020$ & ROW & Plywood & Thamnophis sirtalis \\
\hline $26 \mathrm{~B}$ & $7 / 11 / 2020$ & ROW & Plywood & Thamnophis sirtalis \\
\hline $26 \mathrm{~B}$ & $7 / 11 / 2020$ & ROW & Plywood & Thamnophis sirtalis \\
\hline $26 \mathrm{~B}$ & $7 / 30 / 2020$ & ROW & Plywood & Thamnophis sirtalis \\
\hline $36 \mathrm{~B}$ & $7 / 10 / 2020$ & ROW & Array & Thamnophis sirtalis \\
\hline $4 \mathrm{~B}$ & $6 / 14 / 2020$ & ROW & Array & Thamnophis sirtalis \\
\hline
\end{tabular}


Appendix E: Right of way vegetation measurements were taken 3 times during each pollinator survey. All plots measured $1 \mathrm{~m}^{2}$, and were randomly placed. The tallest piece of vegetation was measured, as well as percent ground cover, and percent of flowering vegetation.

\begin{tabular}{|c|c|c|c|c|c|c|c|c|c|c|}
\hline & & Height & $(\mathrm{cm})$ & & Cover & $(\%)$ & & Flowering & $(\%)$ & \\
\hline Sites & Survey & Plot 1 & Plot 2 & Plot 3 & Plot 1 & Plot 2 & Plot 3 & Plot 1 & Plot 2 & Plot 3 \\
\hline \multirow[t]{4}{*}{$1 \mathrm{a}$} & 1 & 30.48 & 91.44 & 99.06 & 80 & 60 & 70 & 0 & 0 & 10 \\
\hline & 2 & 81.28 & 33.02 & 35.56 & 90 & 65 & 80 & 0 & 0 & 0 \\
\hline & 3 & 71.12 & 66.04 & 53.34 & 100 & 100 & 80 & 25 & 35 & 30 \\
\hline & 4 & 96.52 & 50.8 & 83.82 & 70 & 60 & 90 & 10 & 15 & 30 \\
\hline \multirow[t]{4}{*}{$2 a$} & 1 & 22.86 & 63.5 & 71.12 & 50 & 60 & 40 & 0 & 10 & 0 \\
\hline & 2 & 35.56 & 30.48 & 50.8 & 45 & 80 & 70 & 10 & 5 & 10 \\
\hline & 3 & 81.28 & 68.58 & 66.04 & 70 & 70 & 80 & 50 & 45 & 35 \\
\hline & 4 & 53.34 & 45.72 & 104.14 & 75 & 75 & 75 & 50 & 0 & 20 \\
\hline \multirow[t]{4}{*}{$3 a$} & 1 & 15.24 & 45.72 & 45.72 & 50 & 80 & 75 & 0 & 0 & 0 \\
\hline & 2 & 45.72 & 35.56 & 86.36 & 80 & 50 & 90 & 0 & 0 & 0 \\
\hline & 3 & 71.12 & 63.5 & 78.74 & 75 & 60 & 60 & 30 & 25 & 40 \\
\hline & 4 & 60.96 & 83.82 & 88.9 & 90 & 80 & 100 & 15 & 0 & 25 \\
\hline \multirow[t]{4}{*}{$4 a$} & 1 & 25.4 & 40.64 & 35.56 & 80 & 50 & 50 & 0 & 0 & 0 \\
\hline & 2 & 53.34 & 63.5 & 66.04 & 100 & 80 & 85 & 0 & 0 & 0 \\
\hline & 3 & 91.44 & 93.98 & 76.2 & 90 & 90 & 100 & 35 & 50 & 30 \\
\hline & 4 & 99.06 & 106.68 & 104.14 & 90 & 75 & 100 & 0 & 0 & 0 \\
\hline \multirow[t]{4}{*}{$5 a$} & 1 & 15.24 & 40.64 & 45.72 & 100 & 100 & 100 & 0 & 0 & 0 \\
\hline & 2 & 60.96 & 60.96 & 50.8 & 60 & 80 & 85 & 0 & 0 & 10 \\
\hline & 3 & 99.06 & 78.74 & 50.8 & 100 & 100 & 90 & 40 & 50 & 35 \\
\hline & 4 & 106.68 & 66.04 & 99.06 & 100 & 100 & 100 & 0 & 10 & 0 \\
\hline \multirow[t]{4}{*}{$6 a$} & 1 & 48.26 & 68.58 & 22.86 & 100 & 100 & 100 & 0 & 10 & 0 \\
\hline & 2 & 20.32 & 25.4 & 25.4 & 90 & 45 & 50 & 15 & 60 & 0 \\
\hline & 3 & 76.2 & 45.72 & 66.04 & 70 & 100 & 90 & 60 & 45 & 45 \\
\hline & 4 & 91.44 & 86.36 & 99.06 & 90 & 70 & 60 & 60 & 70 & 60 \\
\hline \multirow[t]{4}{*}{$7 a$} & 1 & 30.48 & 40.64 & 20.32 & 80 & 90 & 100 & 0 & 0 & 0 \\
\hline & 2 & 63.5 & 15.24 & 25.4 & 100 & 90 & 100 & 5 & 45 & 70 \\
\hline & 3 & 81.28 & 149.86 & 99.06 & 90 & 100 & 100 & 25 & 25 & 60 \\
\hline & 4 & 68.58 & 55.88 & 81.28 & 60 & 100 & 100 & 5 & 0 & 0 \\
\hline \multirow[t]{4}{*}{$8 a$} & 1 & 15.24 & 20.32 & 17.78 & 80 & 75 & 90 & 0 & 0 & 0 \\
\hline & 2 & 30.48 & 33.02 & 30.48 & 100 & 100 & 100 & 65 & 70 & 60 \\
\hline & 3 & 25.4 & 91.44 & 35.56 & 90 & 100 & 100 & 75 & 75 & 50 \\
\hline & 4 & 43.18 & 68.58 & 96.52 & 90 & 80 & 100 & 15 & 5 & 25 \\
\hline \multirow[t]{3}{*}{$9 a$} & 1 & 30.48 & 10.16 & 35.56 & 95 & 20 & 100 & 0 & 0 & 10 \\
\hline & 2 & 53.34 & 25.4 & 40.64 & 90 & 70 & 100 & 30 & 25 & 30 \\
\hline & 3 & 35.56 & 50.8 & 53.34 & 80 & 100 & 100 & 75 & 60 & 65 \\
\hline
\end{tabular}




\begin{tabular}{|c|c|c|c|c|c|c|c|c|c|c|}
\hline & 4 & 17.78 & 50.8 & 45.72 & 90 & 100 & 80 & 0 & 10 & 0 \\
\hline \multirow[t]{4}{*}{$10 \mathrm{a}$} & 1 & 12.7 & 10.16 & 15.24 & 75 & 60 & 90 & 0 & 0 & 0 \\
\hline & 2 & 25.4 & 20.32 & 25.4 & 95 & 100 & 90 & 35 & 50 & 65 \\
\hline & 3 & 20.32 & 45.72 & 53.34 & 75 & 100 & 90 & 40 & 60 & 35 \\
\hline & 4 & 30.48 & 38.1 & 63.5 & 60 & 100 & 100 & 0 & 5 & 20 \\
\hline \multirow[t]{4}{*}{$11 \mathrm{a}$} & 1 & 38.1 & 15.24 & 33.02 & 80 & 95 & 100 & 0 & 0 & 0 \\
\hline & 2 & 81.28 & 45.72 & 81.28 & 90 & 100 & 100 & 10 & 5 & 0 \\
\hline & 3 & 76.2 & 25.4 & 86.36 & 100 & 100 & 100 & 30 & 40 & 30 \\
\hline & 4 & 91.44 & 99.06 & 71.12 & 100 & 100 & 100 & 25 & 20 & 10 \\
\hline \multirow[t]{4}{*}{$12 \mathrm{a}$} & 1 & 45.72 & 7.62 & 5.08 & 80 & 60 & 100 & 0 & 0 & 0 \\
\hline & 2 & 22.86 & 15.24 & 25.4 & 95 & 60 & 100 & 10 & 5 & 10 \\
\hline & 3 & 66.04 & 30.48 & 50.8 & 90 & 75 & 80 & 40 & 0 & 25 \\
\hline & 4 & 60.96 & 66.04 & 27.94 & 95 & 70 & 80 & 15 & 30 & 0 \\
\hline \multirow[t]{4}{*}{$13 a$} & 1 & 12.7 & 15.24 & 12.7 & 90 & 100 & 70 & 0 & 0 & 0 \\
\hline & 2 & 15.24 & 22.86 & 35.56 & 100 & 100 & 100 & 10 & 10 & 0 \\
\hline & 3 & 7.62 & 0 & 25.4 & 30 & 0 & 80 & 15 & 0 & 30 \\
\hline & 4 & 66.04 & 20.32 & 15.24 & 100 & 80 & 80 & 10 & 25 & 30 \\
\hline \multirow[t]{4}{*}{$14 \mathrm{a}$} & 1 & 35.56 & 20.32 & 40.64 & 80 & 85 & 80 & 0 & 0 & 0 \\
\hline & 2 & 60.96 & 71.12 & 63.5 & 90 & 100 & 100 & 0 & 0 & 0 \\
\hline & 3 & 111.76 & 96.52 & 60.96 & 100 & 100 & 100 & 10 & 25 & 50 \\
\hline & 4 & 109.22 & 109.22 & 129.54 & 90 & 100 & 100 & 0 & 0 & 10 \\
\hline \multirow[t]{4}{*}{$15 \mathrm{a}$} & 1 & 35.56 & 15.24 & 27.94 & 80 & 75 & 90 & 0 & 0 & 0 \\
\hline & 2 & 20.32 & 33.02 & 35.56 & 75 & 100 & 100 & 5 & 0 & 0 \\
\hline & 3 & 68.58 & 88.9 & 99.06 & 90 & 100 & 100 & 60 & 60 & 50 \\
\hline & 4 & 81.28 & 99.06 & 45.72 & 70 & 100 & 90 & 15 & 15 & 10 \\
\hline \multirow[t]{4}{*}{$16 a$} & 1 & 38.1 & 25.4 & 12.7 & 85 & 100 & 100 & 100 & 0 & 0 \\
\hline & 2 & 55.88 & 45.72 & 50.8 & 95 & 100 & 100 & 10 & 15 & 0 \\
\hline & 3 & 91.44 & 68.58 & 50.8 & 100 & 100 & 80 & 50 & 75 & 40 \\
\hline & 4 & 86.36 & 76.2 & 43.18 & 100 & 100 & 100 & 25 & 10 & 0 \\
\hline \multirow[t]{4}{*}{$17 \mathrm{a}$} & 1 & 30.48 & 45.72 & 15.24 & 50 & 90 & 80 & 0 & 0 & 0 \\
\hline & 2 & 40.64 & 50.8 & 60.96 & 50 & 45 & 75 & 0 & 10 & 0 \\
\hline & 3 & 91.44 & 71.12 & 76.2 & 100 & 60 & 80 & 15 & 20 & 30 \\
\hline & 4 & 99.06 & 50.8 & 48.26 & 100 & 40 & 100 & 10 & 10 & 30 \\
\hline \multirow[t]{4}{*}{$18 \mathrm{a}$} & 1 & 25.4 & 27.94 & 22.86 & 85 & 85 & 90 & 0 & 0 & 0 \\
\hline & 2 & 25.4 & 50.8 & 20.32 & 100 & 100 & 100 & 15 & 5 & 5 \\
\hline & 3 & 104.14 & 116.84 & 30.48 & 100 & 100 & 100 & 20 & 25 & 50 \\
\hline & 4 & 55.88 & 25.4 & 147.32 & 100 & 100 & 100 & 5 & 0 & 40 \\
\hline \multirow[t]{4}{*}{$19 \mathrm{a}$} & 1 & 35.56 & 58.42 & 55.88 & 100 & 85 & 80 & 0 & 0 & 0 \\
\hline & 2 & 81.28 & 50.8 & 76.2 & 60 & 50 & 75 & 0 & 0 & 0 \\
\hline & 3 & 86.36 & 116.84 & 114.3 & 100 & 100 & 100 & 0 & 20 & 50 \\
\hline & 4 & 114.3 & 93.98 & 40.64 & 90 & 90 & 100 & 20 & 35 & 10 \\
\hline
\end{tabular}




\begin{tabular}{|c|c|c|c|c|c|c|c|c|c|c|}
\hline \multirow[t]{4}{*}{$20 \mathrm{a}$} & 1 & 25.4 & 35.56 & 20.32 & 90 & 100 & 85 & 0 & 0 & 0 \\
\hline & 2 & 35.56 & 25.4 & 27.94 & 90 & 100 & 100 & 60 & 70 & 15 \\
\hline & 3 & 45.72 & 30.48 & 116.84 & 80 & 100 & 100 & 30 & 30 & 40 \\
\hline & 4 & 76.2 & 17.78 & 20.32 & 100 & 90 & 80 & 0 & 20 & 10 \\
\hline \multirow[t]{4}{*}{$21 \mathrm{a}$} & 1 & 25.4 & 35.56 & 20.32 & 100 & 100 & 50 & 5 & 0 & 0 \\
\hline & 2 & 55.88 & 40.64 & 30.48 & 85 & 75 & 80 & 0 & 0 & 5 \\
\hline & 3 & 86.36 & 25.4 & 99.06 & 50 & 50 & 80 & 10 & 20 & 25 \\
\hline & 4 & 109.22 & 93.98 & 50.8 & 80 & 100 & 100 & 20 & 20 & 0 \\
\hline \multirow[t]{4}{*}{$22 \mathrm{a}$} & 1 & 17.78 & 27.94 & 20.32 & 50 & 70 & 100 & 0 & 0 & 0 \\
\hline & 2 & 38.1 & 55.88 & 38.1 & 80 & 90 & 100 & 30 & 20 & 60 \\
\hline & 3 & 78.74 & 58.42 & 96.52 & 80 & 80 & 75 & 75 & 25 & 20 \\
\hline & 4 & 50.8 & 58.42 & 78.74 & 100 & 80 & 100 & 35 & 30 & 30 \\
\hline \multirow[t]{4}{*}{$23 a$} & 1 & 25.4 & 40.64 & 12.7 & 100 & 70 & 100 & 0 & 0 & 0 \\
\hline & 2 & 33.02 & 68.58 & 50.8 & 100 & 100 & 100 & 50 & 0 & 65 \\
\hline & 3 & 119.38 & 83.82 & 35.56 & 100 & 100 & 90 & 30 & 40 & 60 \\
\hline & 4 & 106.68 & 116.84 & 38.1 & 100 & 100 & 90 & 0 & 0 & 0 \\
\hline \multirow[t]{4}{*}{$24 \mathrm{a}$} & 1 & 20.32 & 20.32 & 25.4 & 75 & 60 & 80 & 10 & 10 & 10 \\
\hline & 2 & 55.88 & 66.04 & 78.74 & 70 & 85 & 80 & 0 & 0 & 0 \\
\hline & 3 & 88.9 & 99.06 & 91.44 & 90 & 100 & 100 & 0 & 0 & 0 \\
\hline & 4 & 121.92 & 96.52 & 109.22 & 100 & 100 & 100 & 0 & 0 & 0 \\
\hline \multirow[t]{4}{*}{$25 \mathrm{a}$} & 1 & 30.48 & 20.32 & 50.8 & 100 & 50 & 100 & 0 & 0 & 0 \\
\hline & 2 & 45.72 & 38.1 & 40.64 & 80 & 100 & 70 & 0 & 0 & 5 \\
\hline & 3 & 63.5 & 0 & 71.12 & 80 & 0 & 100 & 15 & 0 & 20 \\
\hline & 4 & 96.52 & 17.78 & 88.9 & 80 & 15 & 70 & 0 & 0 & 15 \\
\hline \multirow[t]{4}{*}{$26 a$} & 1 & 35.56 & 15.24 & 12.7 & 55 & 60 & 15 & 0 & 0 & 0 \\
\hline & 2 & 27.94 & 50.8 & 25.4 & 90 & 60 & 100 & 35 & 5 & 20 \\
\hline & 3 & 22.86 & 25.4 & 66.04 & 90 & 80 & 100 & 30 & 40 & 20 \\
\hline & 4 & 50.8 & 66.04 & 33.02 & 80 & 50 & 70 & 10 & 0 & 20 \\
\hline \multirow[t]{4}{*}{$27 \mathrm{a}$} & 1 & 5.08 & 10.16 & 5.08 & 20 & 65 & 10 & 0 & 0 & 0 \\
\hline & 2 & 17.78 & 25.4 & 15.24 & 55 & 100 & 65 & 30 & 30 & 10 \\
\hline & 3 & 38.1 & 60.96 & 30.48 & 60 & 85 & 90 & 20 & 50 & 20 \\
\hline & 4 & 20.32 & 33.02 & 22.86 & 25 & 25 & 60 & 0 & 10 & 0 \\
\hline \multirow[t]{4}{*}{$28 \mathrm{a}$} & 1 & 15.24 & 10.16 & 40.64 & 50 & 70 & 60 & 0 & 0 & 0 \\
\hline & 2 & 53.34 & 76.2 & 86.36 & 75 & 100 & 80 & 25 & 10 & 30 \\
\hline & 3 & 93.98 & 76.2 & 27.94 & 90 & 100 & 80 & 60 & 30 & 30 \\
\hline & 4 & 73.66 & 48.26 & 66.04 & 90 & 100 & 100 & 0 & 25 & 10 \\
\hline \multirow[t]{4}{*}{$29 a$} & 1 & 0 & 15.24 & 15.24 & 0 & 10 & 50 & 0 & 0 & 0 \\
\hline & 2 & 30.48 & 38.1 & 25.4 & 10 & 20 & 10 & 0 & 0 & 0 \\
\hline & 3 & 0 & 53.34 & 20.32 & 0 & 60 & 10 & 0 & 0 & 0 \\
\hline & 4 & 48.26 & 0 & 27.94 & 80 & 0 & 50 & 0 & 0 & 5 \\
\hline $30 a$ & 1 & 12.7 & 10.16 & 10.16 & 85 & 90 & 50 & 0 & 5 & 0 \\
\hline
\end{tabular}




\begin{tabular}{|c|c|c|c|c|c|c|c|c|c|c|}
\hline & 2 & 30.48 & 53.34 & 45.72 & 80 & 90 & 90 & 25 & 20 & 35 \\
\hline & 3 & 53.34 & 60.96 & 50.8 & 100 & 100 & 80 & 20 & 35 & 35 \\
\hline & 4 & 53.34 & 73.66 & 71.12 & 80 & 100 & 65 & 10 & 0 & 0 \\
\hline \multirow[t]{4}{*}{$31 \mathrm{a}$} & 1 & 66.04 & 152.4 & 124.46 & 70 & 100 & 100 & 0 & 0 & 0 \\
\hline & 2 & 35.56 & 53.34 & 38.1 & 100 & 100 & 80 & 30 & 0 & 0 \\
\hline & 3 & 71.12 & 88.9 & 93.98 & 90 & 100 & 100 & 10 & 0 & 0 \\
\hline & 4 & 104.14 & 91.44 & 78.74 & 100 & 100 & 100 & 10 & 5 & 0 \\
\hline \multirow[t]{4}{*}{$32 \mathrm{a}$} & 1 & 81.28 & 73.66 & 25.4 & 85 & 80 & 45 & 0 & 10 & 0 \\
\hline & 2 & 50.8 & 40.64 & 30.48 & 90 & 75 & 100 & 0 & 0 & 20 \\
\hline & 3 & 81.28 & 91.44 & 96.52 & 70 & 80 & 90 & 10 & 50 & 60 \\
\hline & 4 & 101.6 & 58.42 & 119.38 & 90 & 80 & 100 & 20 & 50 & 15 \\
\hline \multirow[t]{4}{*}{$33 a$} & 1 & 12.7 & 10.16 & 20.32 & 30 & 80 & 50 & 0 & 0 & 10 \\
\hline & 2 & 48.26 & 55.88 & 43.18 & 90 & 100 & 100 & 0 & 0 & 0 \\
\hline & 3 & 30.48 & 35.56 & 40.64 & 50 & 60 & 75 & 20 & 15 & 30 \\
\hline & 4 & 104.14 & 38.1 & 33.02 & 90 & 80 & 75 & 40 & 40 & 30 \\
\hline \multirow[t]{4}{*}{$34 \mathrm{a}$} & 1 & 5.08 & 76.2 & 25.4 & 10 & 70 & 65 & 0 & 10 & 0 \\
\hline & 2 & 76.2 & 33.02 & 10.16 & 90 & 60 & 20 & 20 & 10 & 0 \\
\hline & 3 & 73.66 & 81.28 & 76.2 & 90 & 80 & 40 & 50 & 35 & 10 \\
\hline & 4 & 35.56 & 60.96 & 93.98 & 65 & 35 & 80 & 50 & 35 & 15 \\
\hline \multirow[t]{4}{*}{$35 a$} & 1 & 129.54 & 106.68 & 116.84 & 100 & 90 & 100 & 0 & 0 & 0 \\
\hline & 2 & 60.96 & 101.6 & 86.36 & 100 & 100 & 100 & 0 & 0 & 0 \\
\hline & 3 & 106.68 & 91.44 & 66.04 & 100 & 100 & 80 & 0 & 30 & 20 \\
\hline & 4 & 109.22 & 124.46 & 134.62 & 80 & 80 & 100 & 0 & 0 & 0 \\
\hline \multirow[t]{4}{*}{$36 a$} & 1 & 96.52 & 114.3 & 121.92 & 100 & 100 & 100 & 0 & 0 & 0 \\
\hline & 2 & 48.26 & 66.04 & 60.96 & 80 & 100 & 90 & 0 & 0 & 0 \\
\hline & 3 & 99.06 & 109.22 & 58.42 & 100 & 100 & 80 & 0 & 30 & 30 \\
\hline & 4 & 116.84 & 106.68 & 99.06 & 70 & 100 & 90 & 20 & 70 & 0 \\
\hline \multirow[t]{4}{*}{$37 \mathrm{a}$} & 1 & 60.96 & 38.1 & 76.2 & 45 & 55 & 70 & 0 & 0 & 0 \\
\hline & 2 & 40.64 & 53.34 & 50.8 & 45 & 50 & 80 & 0 & 0 & 0 \\
\hline & 3 & 81.28 & 58.42 & 68.58 & 75 & 60 & 100 & 10 & 25 & 25 \\
\hline & 4 & 86.36 & 93.98 & 66.04 & 50 & 90 & 80 & 5 & 50 & 25 \\
\hline \multirow[t]{4}{*}{$38 \mathrm{a}$} & 1 & 81.28 & 111.76 & 76.2 & 65 & 60 & 35 & 0 & 0 & 0 \\
\hline & 2 & 53.34 & 40.64 & 50.8 & 75 & 60 & 80 & 0 & 0 & 0 \\
\hline & 3 & 66.04 & 60.96 & 63.5 & 80 & 75 & 60 & 0 & 15 & 5 \\
\hline & 4 & 86.36 & 68.58 & 88.9 & 90 & 75 & 80 & 25 & 30 & 20 \\
\hline \multirow[t]{4}{*}{$39 a$} & 1 & 40.64 & 35.56 & 45.72 & 90 & 100 & 100 & 20 & 0 & 10 \\
\hline & 2 & 78.74 & 86.36 & 25.4 & 100 & 100 & 90 & 0 & 0 & 30 \\
\hline & 3 & 81.28 & 71.12 & 63.5 & 95 & 100 & 80 & 25 & 0 & 0 \\
\hline & 4 & 93.98 & 109.22 & 86.36 & 100 & 100 & 100 & 5 & 25 & 35 \\
\hline \multirow[t]{2}{*}{$40 \mathrm{a}$} & 1 & 27.94 & 15.24 & 20.32 & 30 & 20 & 60 & 10 & 0 & 0 \\
\hline & 2 & 45.72 & 58.42 & 45.72 & 80 & 65 & 50 & 0 & 0 & 0 \\
\hline
\end{tabular}




\begin{tabular}{|c|c|c|c|c|c|c|c|c|c|c|}
\hline & 3 & 53.34 & 71.12 & 73.66 & 80 & 60 & 75 & 20 & 10 & 10 \\
\hline & 4 & 78.74 & 86.36 & 91.44 & 80 & 75 & 90 & 25 & 10 & 20 \\
\hline \multirow[t]{4}{*}{$1 b$} & 1 & 66.04 & 78.74 & 30.48 & 80 & 90 & 100 & 0 & 10 & 0 \\
\hline & 2 & 66.04 & 55.88 & 50.8 & 90 & 80 & 100 & 0 & 0 & 0 \\
\hline & 3 & 81.28 & 63.5 & 99.06 & 100 & 100 & 100 & 75 & 60 & 75 \\
\hline & 4 & 99.06 & 106.68 & 114.3 & 100 & 100 & 100 & 50 & 20 & 75 \\
\hline \multirow[t]{4}{*}{$2 b$} & 1 & 33.02 & 35.56 & 78.74 & 50 & 60 & 90 & 0 & 0 & 0 \\
\hline & 2 & 38.1 & 76.2 & 66.04 & 60 & 60 & 75 & 0 & 0 & 10 \\
\hline & 3 & 96.52 & 66.04 & 45.72 & 80 & 70 & 80 & 30 & 0 & 5 \\
\hline & 4 & 124.46 & 30.48 & 22.86 & 100 & 100 & 90 & 30 & 0 & 0 \\
\hline \multirow[t]{4}{*}{$3 b$} & 1 & 25.4 & 20.32 & 30.48 & 80 & 80 & 70 & 0 & 0 & 0 \\
\hline & 2 & 60.96 & 25.4 & 25.4 & 85 & 70 & 80 & 0 & 0 & 0 \\
\hline & 3 & 20.32 & 66.04 & 35.56 & 75 & 80 & 70 & 0 & 0 & 20 \\
\hline & 4 & 50.8 & 25.4 & 48.26 & 80 & 90 & 100 & 5 & 0 & 15 \\
\hline \multirow[t]{4}{*}{$4 b$} & 1 & 38.1 & 20.32 & 73.66 & 80 & 100 & 100 & 5 & 10 & 5 \\
\hline & 2 & 55.88 & 25.4 & 91.44 & 80 & 40 & 60 & 10 & 0 & 15 \\
\hline & 3 & 35.56 & 142.24 & 121.92 & 100 & 90 & 75 & 75 & 75 & 60 \\
\hline & 4 & 142.24 & 124.46 & 132.08 & 90 & 100 & 100 & 60 & 40 & 70 \\
\hline \multirow[t]{4}{*}{$5 b$} & 1 & 43.18 & 50.8 & 10.16 & 100 & 100 & 100 & 0 & 0 & 15 \\
\hline & 2 & 35.56 & 48.26 & 40.64 & 70 & 80 & 60 & 0 & 0 & 0 \\
\hline & 3 & 83.82 & 33.02 & 93.98 & 100 & 60 & 90 & 60 & 10 & 25 \\
\hline & 4 & 76.2 & 50.8 & 83.82 & 80 & 100 & 90 & 10 & 70 & 20 \\
\hline \multirow[t]{4}{*}{$6 b$} & 1 & 27.94 & 86.36 & 93.98 & 60 & 35 & 50 & 0 & 0 & 0 \\
\hline & 2 & 71.12 & 38.1 & 55.88 & 80 & 55 & 90 & 0 & 0 & 0 \\
\hline & 3 & 129.54 & 99.06 & 81.28 & 75 & 100 & 90 & 60 & 0 & 0 \\
\hline & 4 & 83.82 & 76.2 & 35.56 & 100 & 80 & 40 & 0 & 0 & 0 \\
\hline \multirow[t]{4}{*}{$7 b$} & 1 & 43.18 & 25.4 & 40.64 & 100 & 100 & 100 & 0 & 0 & 0 \\
\hline & 2 & 40.64 & 53.34 & 60.96 & 90 & 60 & 75 & 0 & 0 & 10 \\
\hline & 3 & 86.36 & 91.44 & 78.74 & 90 & 100 & 100 & 10 & 35 & 40 \\
\hline & 4 & 137.16 & 147.32 & 127 & 75 & 100 & 80 & 5 & 0 & 15 \\
\hline \multirow[t]{4}{*}{$8 b$} & 1 & 15.24 & 30.48 & 17.78 & 100 & 100 & 100 & 5 & 0 & 0 \\
\hline & 2 & 63.5 & 48.26 & 63.5 & 100 & 100 & 100 & 0 & 20 & 0 \\
\hline & 3 & 45.72 & 76.2 & 81.28 & 80 & 80 & 70 & 30 & 5 & 5 \\
\hline & 4 & 50.8 & 78.74 & 116.84 & 90 & 100 & 80 & 25 & 25 & 10 \\
\hline \multirow[t]{4}{*}{$9 b$} & 1 & 10.16 & 25.4 & 58.42 & 100 & 100 & 100 & 0 & 0 & 0 \\
\hline & 2 & 55.88 & 63.5 & 53.34 & 70 & 50 & 60 & 0 & 0 & 0 \\
\hline & 3 & 86.36 & 43.18 & 66.04 & 100 & 100 & 100 & 0 & 0 & 5 \\
\hline & 4 & 73.66 & 81.28 & 81.28 & 90 & 90 & 90 & 0 & 0 & 0 \\
\hline \multirow[t]{3}{*}{$10 \mathrm{~b}$} & 1 & 30.48 & 96.52 & 76.2 & 100 & 100 & 100 & 0 & 0 & 0 \\
\hline & 2 & 60.96 & 53.34 & 55.88 & 50 & 40 & 65 & 0 & 0 & 0 \\
\hline & 3 & 99.06 & 71.12 & 109.22 & 80 & 90 & 100 & 60 & 0 & 60 \\
\hline
\end{tabular}




\begin{tabular}{|c|c|c|c|c|c|c|c|c|c|c|}
\hline & 4 & 88.9 & 76.2 & 93.98 & 80 & 100 & 100 & 20 & 0 & 0 \\
\hline \multirow[t]{4}{*}{$11 b$} & 1 & 81.28 & 25.4 & 15.24 & 100 & 100 & 100 & 0 & 0 & 0 \\
\hline & 2 & 55.88 & 66.04 & 66.04 & 80 & 75 & 50 & 0 & 0 & 0 \\
\hline & 3 & 96.52 & 106.68 & 91.44 & 80 & 90 & 100 & 0 & 30 & 0 \\
\hline & 4 & 101.6 & 93.98 & 96.52 & 100 & 100 & 90 & 0 & 0 & 0 \\
\hline \multirow[t]{4}{*}{$12 b$} & 1 & 33.02 & 17.78 & 30.48 & 100 & 100 & 100 & 0 & 0 & 0 \\
\hline & 2 & 60.96 & 7.62 & 78.74 & 60 & 20 & 70 & 0 & 0 & 0 \\
\hline & 3 & 53.34 & 45.72 & 76.2 & 60 & 100 & 75 & 0 & 45 & 10 \\
\hline & 4 & 66.04 & 58.42 & 88.9 & 90 & 30 & 80 & 5 & 0 & 10 \\
\hline \multirow[t]{4}{*}{$13 b$} & 1 & 15.24 & 20.32 & 20.32 & 80 & 90 & 85 & 0 & 0 & 0 \\
\hline & 2 & 50.8 & 27.94 & 25.4 & 80 & 70 & 70 & 0 & 0 & 0 \\
\hline & 3 & 60.96 & 45.72 & 68.58 & 40 & 50 & 75 & 0 & 0 & 10 \\
\hline & 4 & 55.88 & 25.4 & 60.96 & 60 & 70 & 50 & 0 & 0 & 0 \\
\hline \multirow[t]{4}{*}{$14 b$} & 1 & 7.62 & 91.44 & 20.32 & 90 & 75 & 90 & 0 & 0 & 0 \\
\hline & 2 & 76.2 & 63.5 & 60.96 & 50 & 60 & 75 & 0 & 0 & 0 \\
\hline & 3 & 86.36 & 93.98 & 81.28 & 90 & 100 & 85 & 0 & 0 & 0 \\
\hline & 4 & 88.9 & 99.06 & 83.82 & 60 & 80 & 75 & 0 & 0 & 0 \\
\hline \multirow[t]{4}{*}{$17 b$} & 1 & 25.4 & 142.24 & 121.92 & 100 & 100 & 100 & 10 & 0 & 0 \\
\hline & 2 & 50.8 & 76.2 & 104.14 & 80 & 90 & 80 & 0 & 0 & 0 \\
\hline & 3 & 81.28 & 144.78 & 177.8 & 80 & 100 & 100 & 0 & 40 & 50 \\
\hline & 4 & 187.96 & 170.18 & 129.54 & 100 & 100 & 100 & 90 & 90 & 50 \\
\hline \multirow[t]{4}{*}{$18 b$} & 1 & 152.4 & 71.12 & 119.38 & 100 & 100 & 100 & 20 & 0 & 0 \\
\hline & 2 & 86.36 & 76.2 & 101.6 & 90 & 75 & 80 & 0 & 25 & 0 \\
\hline & 3 & 99.06 & 109.22 & 101.6 & 100 & 100 & 100 & 60 & 30 & 45 \\
\hline & 4 & 139.7 & 101.6 & 109.22 & 100 & 100 & 80 & 30 & 40 & 40 \\
\hline \multirow[t]{4}{*}{$19 b$} & 1 & 5.08 & 73.66 & 35.56 & 100 & 80 & 100 & 0 & 0 & 10 \\
\hline & 2 & 25.4 & 38.1 & 60.96 & 30 & 75 & 90 & 0 & 30 & 0 \\
\hline & 3 & 101.6 & 99.06 & 45.72 & 60 & 100 & 75 & 0 & 0 & 0 \\
\hline & 4 & 96.52 & 86.36 & 88.9 & 100 & 100 & 100 & 15 & 0 & 0 \\
\hline \multirow[t]{4}{*}{$20 \mathrm{~b}$} & 1 & 121.92 & 78.74 & 25.4 & 100 & 100 & 100 & 10 & 10 & 0 \\
\hline & 2 & 99.06 & 104.14 & 93.98 & 75 & 85 & 100 & 0 & 10 & 5 \\
\hline & 3 & 66.04 & 53.34 & 50.8 & 70 & 50 & 100 & 20 & 0 & 10 \\
\hline & 4 & 96.52 & 96.52 & 104.14 & 80 & 60 & 75 & 20 & 10 & 0 \\
\hline \multirow[t]{4}{*}{$21 b$} & 1 & 5.08 & 91.44 & 53.34 & 100 & 80 & 100 & 0 & 20 & 0 \\
\hline & 2 & 35.56 & 50.8 & 55.88 & 60 & 50 & 80 & 0 & 0 & 50 \\
\hline & 3 & 96.52 & 104.14 & 76.2 & 75 & 90 & 80 & 0 & 50 & 0 \\
\hline & 4 & 101.6 & 109.22 & 96.52 & 100 & 80 & 100 & 0 & 20 & 0 \\
\hline \multirow[t]{4}{*}{$22 b$} & 1 & 25.4 & 35.56 & 73.66 & 100 & 100 & 100 & 0 & 0 & 0 \\
\hline & 2 & 43.18 & 43.18 & 58.42 & 75 & 50 & 80 & 0 & 0 & 20 \\
\hline & 3 & 101.6 & 93.98 & 96.52 & 100 & 100 & 100 & 0 & 0 & 0 \\
\hline & 4 & 99.06 & 93.98 & 104.14 & 100 & 100 & 85 & 0 & 0 & 0 \\
\hline
\end{tabular}




\begin{tabular}{|c|c|c|c|c|c|c|c|c|c|c|}
\hline \multirow[t]{4}{*}{$23 b$} & 1 & 35.56 & 15.24 & 60.96 & 100 & 100 & 100 & 0 & 0 & 0 \\
\hline & 2 & 78.74 & 50.8 & 60.96 & 85 & 40 & 75 & 0 & 0 & 60 \\
\hline & 3 & 81.28 & 50.8 & 40.64 & 80 & 75 & 40 & 0 & 0 & 0 \\
\hline & 4 & 33.02 & 53.34 & 20.32 & 40 & 75 & 50 & 0 & 0 & 0 \\
\hline \multirow[t]{4}{*}{$24 b$} & 1 & 172.72 & 68.58 & 76.2 & 60 & 70 & 65 & 0 & 0 & 0 \\
\hline & 2 & 86.36 & 33.02 & 91.44 & 75 & 60 & 80 & 0 & 0 & 0 \\
\hline & 3 & 71.12 & 53.34 & 81.28 & 80 & 70 & 60 & 0 & 0 & 0 \\
\hline & 4 & 83.82 & 66.04 & 91.44 & 100 & 90 & 100 & 0 & 0 & 0 \\
\hline \multirow[t]{4}{*}{$25 b$} & 1 & 15.24 & 22.86 & 17.78 & 100 & 80 & 85 & 0 & 0 & 0 \\
\hline & 2 & 58.42 & 50.8 & 45.72 & 60 & 80 & 80 & 0 & 5 & 15 \\
\hline & 3 & 58.42 & 66.04 & 76.2 & 80 & 100 & 90 & 0 & 0 & 20 \\
\hline & 4 & 93.98 & 96.52 & 116.84 & 70 & 100 & 100 & 0 & 0 & 25 \\
\hline \multirow[t]{4}{*}{$26 b$} & 1 & 30.48 & 50.8 & 22.86 & 40 & 70 & 50 & 5 & 0 & 0 \\
\hline & 2 & 40.64 & 33.02 & 63.5 & 70 & 80 & 40 & 0 & 0 & 5 \\
\hline & 3 & 66.04 & 111.76 & 129.54 & 40 & 80 & 50 & 0 & 40 & 30 \\
\hline & 4 & 86.36 & 99.06 & 121.92 & 80 & 90 & 100 & 0 & 30 & 30 \\
\hline \multirow[t]{4}{*}{$27 \mathrm{~b}$} & 1 & 99.06 & 20.32 & 30.48 & 85 & 70 & 55 & 5 & 0 & 0 \\
\hline & 2 & 50.8 & 58.42 & 66.04 & 55 & 40 & 50 & 0 & 0 & 0 \\
\hline & 3 & 73.66 & 76.2 & 91.44 & 90 & 100 & 90 & 20 & 0 & 0 \\
\hline & 4 & 81.28 & 93.98 & 106.68 & 90 & 75 & 100 & 0 & 0 & 0 \\
\hline \multirow[t]{4}{*}{$28 b$} & 1 & 15.24 & 10.16 & 17.78 & 100 & 100 & 100 & 0 & 0 & 0 \\
\hline & 2 & 40.64 & 53.34 & 50.8 & 70 & 90 & 60 & 0 & 0 & 0 \\
\hline & 3 & 76.2 & 83.82 & 86.36 & 75 & 90 & 100 & 0 & 0 & 0 \\
\hline & 4 & 111.76 & 109.22 & 81.28 & 90 & 100 & 100 & 0 & 10 & 0 \\
\hline \multirow[t]{4}{*}{$29 b$} & 1 & 10.16 & 15.24 & 15.24 & 50 & 80 & 100 & 0 & 0 & 0 \\
\hline & 2 & 45.72 & 60.96 & 45.72 & 80 & 90 & 60 & 0 & 0 & 0 \\
\hline & 3 & 96.52 & 96.52 & 88.9 & 90 & 100 & 100 & 0 & 0 & 0 \\
\hline & 4 & 106.68 & 88.9 & 66.04 & 100 & 100 & 80 & 0 & 10 & 10 \\
\hline \multirow[t]{4}{*}{$30 \mathrm{~b}$} & 1 & 38.1 & 78.74 & 55.88 & 90 & 65 & 80 & 0 & 0 & 0 \\
\hline & 2 & 35.56 & 40.64 & 60.96 & 100 & 100 & 100 & 0 & 5 & 0 \\
\hline & 3 & 76.2 & 76.2 & 81.28 & 80 & 70 & 60 & 10 & 25 & 25 \\
\hline & 4 & 114.3 & 93.98 & 50.8 & 100 & 100 & 60 & 0 & 20 & 0 \\
\hline \multirow[t]{4}{*}{$31 b$} & 1 & 15.24 & 17.78 & 30.48 & 80 & 70 & 100 & 0 & 15 & 0 \\
\hline & 2 & 63.5 & 50.8 & 12.7 & 85 & 80 & 35 & 0 & 25 & 0 \\
\hline & 3 & 53.34 & 50.8 & 22.86 & 85 & 100 & 65 & 25 & 40 & 50 \\
\hline & 4 & 38.1 & 88.9 & 93.98 & 80 & 90 & 100 & 0 & 5 & 0 \\
\hline \multirow[t]{4}{*}{$32 b$} & 1 & 35.56 & 22.86 & 86.36 & 100 & 100 & 100 & 0 & 0 & 0 \\
\hline & 2 & 71.12 & 63.5 & 68.58 & 90 & 75 & 75 & 0 & 0 & 0 \\
\hline & 3 & 78.74 & 86.36 & 86.36 & 90 & 70 & 75 & 20 & 30 & 30 \\
\hline & 4 & 167.64 & 96.52 & 109.22 & 60 & 80 & 100 & 40 & 0 & 10 \\
\hline $33 b$ & 1 & 144.78 & 83.82 & 30.48 & 100 & 100 & 100 & 0 & 0 & 0 \\
\hline
\end{tabular}




\begin{tabular}{|c|c|c|c|c|c|c|c|c|c|c|}
\hline & 2 & 20.32 & 48.26 & 60.96 & 90 & 60 & 35 & 40 & 0 & 10 \\
\hline & 3 & 43.18 & 78.74 & 66.04 & 100 & 80 & 80 & 40 & 15 & 25 \\
\hline & 4 & 104.14 & 109.22 & 66.04 & 80 & 70 & 90 & 0 & 30 & 15 \\
\hline \multirow[t]{4}{*}{$34 b$} & 1 & 27.94 & 30.48 & 91.44 & 100 & 100 & 100 & 5 & 10 & 0 \\
\hline & 2 & 86.36 & 45.72 & 25.4 & 60 & 50 & 70 & 0 & 0 & 0 \\
\hline & 3 & 96.52 & 83.82 & 96.52 & 75 & 75 & 80 & 0 & 0 & 0 \\
\hline & 4 & 129.54 & 114.3 & 134.62 & 90 & 80 & 60 & 0 & 0 & 20 \\
\hline \multirow[t]{4}{*}{$35 b$} & 1 & 30.48 & 45.72 & 20.32 & 100 & 100 & 100 & 0 & 0 & 0 \\
\hline & 2 & 66.04 & 76.2 & 76.2 & 50 & 80 & 60 & 0 & 0 & 0 \\
\hline & 3 & 93.98 & 99.06 & 101.6 & 90 & 80 & 65 & 25 & 10 & 0 \\
\hline & 4 & 78.74 & 86.36 & 86.36 & 70 & 85 & 60 & 0 & 20 & 0 \\
\hline \multirow[t]{4}{*}{$36 \mathrm{~b}$} & 1 & 30.48 & 53.34 & 96.52 & 80 & 75 & 95 & 0 & 10 & 0 \\
\hline & 2 & 35.56 & 40.64 & 40.64 & 45 & 30 & 65 & 0 & 0 & 10 \\
\hline & 3 & 66.04 & 73.66 & 78.74 & 40 & 60 & 30 & 10 & 0 & 0 \\
\hline & 4 & 76.2 & 93.98 & 93.98 & 90 & 65 & 80 & 10 & 20 & 25 \\
\hline \multirow[t]{4}{*}{$37 b$} & 1 & 78.74 & 60.96 & 25.4 & 80 & 70 & 100 & 0 & 0 & 10 \\
\hline & 2 & 33.02 & 45.72 & 50.8 & 60 & 50 & 75 & 0 & 0 & 10 \\
\hline & 3 & 104.14 & 86.36 & 30.48 & 90 & 50 & 50 & 35 & 0 & 10 \\
\hline & 4 & 68.58 & 33.02 & 58.42 & 80 & 60 & 50 & 10 & 10 & 5 \\
\hline \multirow[t]{4}{*}{$38 b$} & 1 & 40.64 & 27.94 & 35.56 & 45 & 70 & 50 & 0 & 30 & 5 \\
\hline & 2 & 50.8 & 55.88 & 35.56 & 60 & 75 & 80 & 0 & 10 & 5 \\
\hline & 3 & 50.8 & 60.96 & 66.04 & 40 & 80 & 80 & 0 & 50 & 0 \\
\hline & 4 & 63.5 & 53.34 & 55.88 & 75 & 50 & 90 & 20 & 25 & 10 \\
\hline \multirow[t]{4}{*}{$39 b$} & 1 & 66.04 & 25.4 & 78.74 & 100 & 100 & 100 & 0 & 0 & 0 \\
\hline & 2 & 91.44 & 50.8 & 58.42 & 65 & 45 & 70 & 20 & 0 & 0 \\
\hline & 3 & 116.84 & 71.12 & 83.82 & 100 & 80 & 90 & 30 & 40 & 0 \\
\hline & 4 & 63.5 & 96.52 & 73.66 & 80 & 95 & 100 & 10 & 0 & 20 \\
\hline \multirow[t]{4}{*}{$40 \mathrm{~b}$} & 1 & 17.78 & 60.96 & 88.9 & 100 & 100 & 100 & 0 & 0 & 0 \\
\hline & 2 & 53.34 & 60.96 & 40.64 & 80 & 60 & 65 & 0 & 0 & 0 \\
\hline & 3 & 76.2 & 104.14 & 66.04 & 50 & 100 & 60 & 0 & 50 & 0 \\
\hline & 4 & 73.66 & 88.9 & 53.34 & 100 & 90 & 60 & 15 & 10 & 0 \\
\hline \multirow[t]{4}{*}{$41 b$} & 1 & 25.4 & 15.24 & 27.94 & 100 & 100 & 100 & 0 & 0 & 0 \\
\hline & 2 & 60.96 & 71.12 & 60.96 & 80 & 100 & 60 & 0 & 0 & 0 \\
\hline & 3 & 114.3 & 104.14 & 109.22 & 100 & 100 & 100 & 10 & 0 & 0 \\
\hline & 4 & 96.52 & 93.98 & 86.36 & 100 & 100 & 80 & 5 & 10 & 0 \\
\hline \multirow[t]{4}{*}{$42 b$} & 1 & 104.14 & 25.4 & 48.26 & 100 & 100 & 100 & 0 & 0 & 0 \\
\hline & 2 & 68.58 & 81.28 & 71.12 & 65 & 75 & 45 & 0 & 0 & 0 \\
\hline & 3 & 99.06 & 106.68 & 86.36 & 80 & 75 & 50 & 0 & 0 & 0 \\
\hline & 4 & 83.82 & 101.6 & 91.44 & 60 & 90 & 75 & 0 & 0 & 0 \\
\hline
\end{tabular}


Appendix F: Forest structure measurements surrounding cover board sites. Canopy height was measured using a laser rangefinder. Canopy cover was measured using a spherical densitometer, and is the $\%$ of canopy covered. Tree count is the number of trees with a diameter at breast height (dbh) larger than $15.24 \mathrm{~cm}$ within $10 \mathrm{~m}$ of the cover board. Tree DBH is the added dbh of tree count in $\mathrm{cm}$. Stems were counted within an $8 \mathrm{~m}^{2}$ plot around the cover boards.

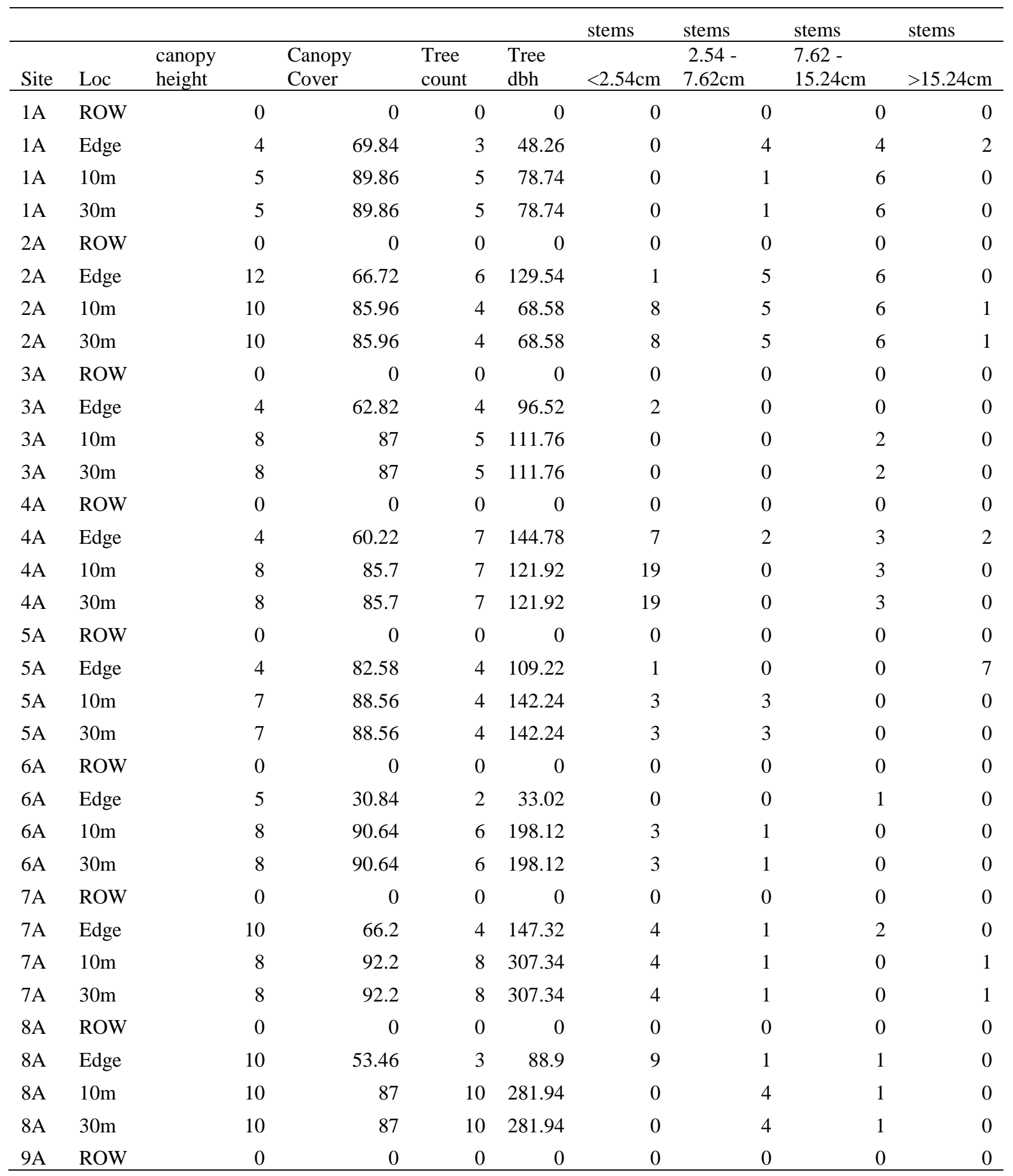




\begin{tabular}{|c|c|c|c|c|c|c|c|c|c|}
\hline $9 \mathrm{~A}$ & Edge & 11 & 86.22 & 6 & 195.58 & 0 & 1 & 0 & 1 \\
\hline $9 \mathrm{~A}$ & $10 \mathrm{~m}$ & 14 & 85.7 & 13 & 353.06 & 11 & 2 & 0 & 4 \\
\hline $9 \mathrm{~A}$ & $30 \mathrm{~m}$ & 14 & 85.7 & 13 & 353.06 & 11 & 2 & 0 & 4 \\
\hline $10 \mathrm{~A}$ & ROW & 0 & 0 & 0 & 0 & 0 & 0 & 0 & 0 \\
\hline $10 \mathrm{~A}$ & Edge & 10 & 90.38 & 7 & 185.42 & 7 & 1 & 3 & 0 \\
\hline $10 \mathrm{~A}$ & $10 \mathrm{~m}$ & 4 & 93.24 & 0 & 0 & 11 & 14 & 2 & 0 \\
\hline $10 \mathrm{~A}$ & $30 \mathrm{~m}$ & 4 & 93.24 & 0 & 0 & 11 & 14 & 2 & 0 \\
\hline $11 \mathrm{~A}$ & ROW & 0 & 0 & 0 & 0 & 0 & 0 & 0 & 0 \\
\hline $11 \mathrm{~A}$ & Edge & 10 & 74 & 5 & 124.46 & 0 & 0 & 0 & 0 \\
\hline $11 \mathrm{~A}$ & $10 \mathrm{~m}$ & 10 & 90.12 & 6 & 198.12 & 1 & 4 & 0 & 1 \\
\hline $11 \mathrm{~A}$ & $30 \mathrm{~m}$ & 10 & 90.12 & 6 & 198.12 & 1 & 4 & 0 & 1 \\
\hline $12 \mathrm{~A}$ & ROW & 0 & 0 & 0 & 0 & 0 & 0 & 0 & 0 \\
\hline $12 \mathrm{~A}$ & Edge & 5 & 72.18 & 2 & 55.88 & 0 & 0 & 0 & 1 \\
\hline $12 \mathrm{~A}$ & $10 \mathrm{~m}$ & 6 & 78.94 & 4 & 88.9 & 2 & 0 & 0 & 1 \\
\hline $12 \mathrm{~A}$ & $30 \mathrm{~m}$ & 6 & 78.94 & 4 & 88.9 & 2 & 0 & 0 & 1 \\
\hline $13 \mathrm{~A}$ & ROW & 0 & 0 & 0 & 0 & 0 & 0 & 0 & 0 \\
\hline $13 \mathrm{~A}$ & Edge & 3 & 68.54 & 1 & 50.8 & 0 & 3 & 1 & 0 \\
\hline $13 \mathrm{~A}$ & $10 \mathrm{~m}$ & 2 & 90.12 & 3 & 55.88 & 2 & 0 & 1 & 0 \\
\hline $13 \mathrm{~A}$ & $30 \mathrm{~m}$ & 2 & 90.12 & 3 & 55.88 & 2 & 0 & 1 & 0 \\
\hline $14 \mathrm{~A}$ & ROW & 0 & 0 & 0 & 0 & 0 & 0 & 0 & 0 \\
\hline $14 \mathrm{~A}$ & Edge & 10 & 70.1 & 3 & 96.52 & 14 & 0 & 0 & 0 \\
\hline $14 \mathrm{~A}$ & $10 \mathrm{~m}$ & 8 & 85.44 & 6 & 226.06 & 1 & 2 & 0 & 2 \\
\hline $14 \mathrm{~A}$ & $30 \mathrm{~m}$ & 8 & 85.44 & 6 & 226.06 & 1 & 2 & 0 & 2 \\
\hline $15 \mathrm{~A}$ & ROW & 0 & 0 & 0 & 0 & 0 & 0 & 0 & 0 \\
\hline $15 \mathrm{~A}$ & Edge & 4 & 32.92 & 2 & 93.98 & 6 & 0 & 0 & 0 \\
\hline $15 \mathrm{~A}$ & $10 \mathrm{~m}$ & 8 & 69.06 & 4 & 157.48 & 3 & 0 & 0 & 0 \\
\hline $15 \mathrm{~A}$ & $30 \mathrm{~m}$ & 8 & 69.06 & 4 & 157.48 & 3 & 0 & 0 & 0 \\
\hline $16 \mathrm{~A}$ & ROW & 0 & 0 & 0 & 0 & 0 & 0 & 0 & 0 \\
\hline $16 \mathrm{~A}$ & Edge & 3 & 87 & 7 & 175.26 & 0 & 1 & 2 & 1 \\
\hline $16 \mathrm{~A}$ & $10 \mathrm{~m}$ & 10 & 76.08 & 10 & 200.66 & 7 & 1 & 2 & 0 \\
\hline $16 \mathrm{~A}$ & $30 \mathrm{~m}$ & 10 & 76.08 & 10 & 200.66 & 7 & 1 & 2 & 0 \\
\hline $17 \mathrm{~A}$ & ROW & 0 & 0 & 0 & 0 & 0 & 0 & 0 & 0 \\
\hline $17 \mathrm{~A}$ & Edge & 8 & 26.68 & 1 & 15.24 & 0 & 6 & 0 & 0 \\
\hline $17 \mathrm{~A}$ & $10 \mathrm{~m}$ & 6 & 92.98 & 3 & 109.22 & 0 & 3 & 0 & 0 \\
\hline $17 \mathrm{~A}$ & $30 \mathrm{~m}$ & 6 & 92.98 & 3 & 109.22 & 0 & 3 & 0 & 0 \\
\hline $18 \mathrm{~A}$ & ROW & 0 & 0 & 0 & 0 & 0 & 0 & 0 & 0 \\
\hline $18 \mathrm{~A}$ & Edge & 0 & 0.16 & 0 & 0 & 0 & 0 & 0 & 0 \\
\hline $18 \mathrm{~A}$ & $10 \mathrm{~m}$ & 5 & 56.84 & 6 & 129.54 & 2 & 1 & 0 & 0 \\
\hline $18 \mathrm{~A}$ & $30 \mathrm{~m}$ & 5 & 56.84 & 6 & 129.54 & 2 & 1 & 0 & 0 \\
\hline $19 \mathrm{~A}$ & ROW & 0 & 0 & 0 & 0 & 0 & 0 & 0 & 0 \\
\hline $19 \mathrm{~A}$ & Edge & 2 & 92.2 & 9 & 185.42 & 7 & 0 & 0 & 2 \\
\hline
\end{tabular}




\begin{tabular}{|c|c|c|c|c|c|c|c|c|c|}
\hline $19 \mathrm{~A}$ & $10 \mathrm{~m}$ & 5 & 89.08 & 20 & 538.48 & 2 & 3 & 0 & 2 \\
\hline $19 \mathrm{~A}$ & $30 \mathrm{~m}$ & 5 & 89.08 & 20 & 538.48 & 2 & 3 & 0 & 2 \\
\hline $20 \mathrm{~A}$ & ROW & 0 & 0 & 0 & 0 & 0 & 0 & 0 & 0 \\
\hline $20 \mathrm{~A}$ & Edge & 6 & 78.94 & 1 & 17.78 & 2 & 1 & 1 & 0 \\
\hline $20 \mathrm{~A}$ & $10 \mathrm{~m}$ & 8 & 90.38 & 6 & 203.2 & 4 & 2 & 0 & 1 \\
\hline $20 \mathrm{~A}$ & $30 \mathrm{~m}$ & 8 & 90.38 & 6 & 203.2 & 4 & 2 & 0 & 1 \\
\hline $21 \mathrm{~A}$ & ROW & 0 & 0 & 0 & 0 & 0 & 0 & 0 & 0 \\
\hline $21 \mathrm{~A}$ & Edge & 2 & 63.08 & 7 & 200.66 & 10 & 1 & 0 & 0 \\
\hline $21 \mathrm{~A}$ & $10 \mathrm{~m}$ & 4 & 89.6 & 18 & 502.92 & 6 & 0 & 2 & 0 \\
\hline $21 \mathrm{~A}$ & $30 \mathrm{~m}$ & 4 & 89.6 & 18 & 502.92 & 6 & 0 & 2 & 0 \\
\hline $22 \mathrm{~A}$ & ROW & 0 & 0 & 0 & 0 & 0 & 0 & 0 & 0 \\
\hline $22 \mathrm{~A}$ & Edge & 5 & 87.78 & 0 & 0 & 8 & 2 & 2 & 0 \\
\hline $22 \mathrm{~A}$ & $10 \mathrm{~m}$ & 5 & 90.64 & 0 & 0 & 0 & 6 & 3 & 0 \\
\hline $22 \mathrm{~A}$ & $30 \mathrm{~m}$ & 5 & 90.64 & 0 & 0 & 0 & 6 & 3 & 0 \\
\hline $23 \mathrm{~A}$ & ROW & 0 & 0 & 0 & 0 & 0 & 0 & 0 & 0 \\
\hline $23 \mathrm{~A}$ & Edge & 5 & 48.52 & 4 & 124.46 & 7 & 1 & 0 & 0 \\
\hline $23 \mathrm{~A}$ & $10 \mathrm{~m}$ & 6 & 88.56 & 6 & 127 & 4 & 0 & 0 & 1 \\
\hline $23 \mathrm{~A}$ & $30 \mathrm{~m}$ & 6 & 88.56 & 6 & 127 & 4 & 0 & 0 & 1 \\
\hline $24 \mathrm{~A}$ & ROW & 0 & 0 & 0 & 0 & 0 & 0 & 0 & 0 \\
\hline $24 \mathrm{~A}$ & Edge & 10 & 63.6 & 4 & 147.32 & 3 & 0 & 2 & 0 \\
\hline $24 \mathrm{~A}$ & $10 \mathrm{~m}$ & 13 & 82.06 & 9 & 271.78 & 2 & 1 & 0 & 4 \\
\hline $24 \mathrm{~A}$ & $30 \mathrm{~m}$ & 13 & 82.06 & 9 & 271.78 & 2 & 1 & 0 & 4 \\
\hline $25 \mathrm{~A}$ & ROW & 0 & 0 & 0 & 0 & 0 & 0 & 0 & 0 \\
\hline $25 \mathrm{~A}$ & Edge & 6 & 48 & 4 & 180.34 & 5 & 1 & 1 & 1 \\
\hline $25 \mathrm{~A}$ & $10 \mathrm{~m}$ & 6 & 90.38 & 4 & 109.22 & 0 & 0 & 2 & 0 \\
\hline $25 \mathrm{~A}$ & $30 \mathrm{~m}$ & 6 & 90.38 & 4 & 109.22 & 0 & 0 & 2 & 0 \\
\hline $26 \mathrm{~A}$ & ROW & 0 & 0 & 0 & 0 & 0 & 0 & 0 & 0 \\
\hline $26 \mathrm{~A}$ & Edge & 0 & 18.1 & 2 & 50.8 & 5 & 1 & 1 & 1 \\
\hline $26 \mathrm{~A}$ & $10 \mathrm{~m}$ & 8 & 16.28 & 2 & 43.18 & 0 & 0 & 0 & 0 \\
\hline $26 \mathrm{~A}$ & $30 \mathrm{~m}$ & 8 & 16.28 & 2 & 43.18 & 0 & 0 & 0 & 0 \\
\hline $27 \mathrm{~A}$ & ROW & 0 & 0 & 0 & 0 & 0 & 0 & 0 & 0 \\
\hline $27 \mathrm{~A}$ & Edge & 13 & 20.7 & 2 & 99.06 & 0 & 0 & 0 & 0 \\
\hline $27 \mathrm{~A}$ & $10 \mathrm{~m}$ & 13 & 32.4 & 3 & 139.7 & 4 & 0 & 0 & 1 \\
\hline $27 \mathrm{~A}$ & $30 \mathrm{~m}$ & 13 & 32.4 & 3 & 139.7 & 4 & 0 & 0 & 1 \\
\hline $28 \mathrm{~A}$ & ROW & 0 & 0 & 0 & 0 & 0 & 0 & 0 & 0 \\
\hline $28 \mathrm{~A}$ & Edge & 6 & 49.56 & 7 & 213.36 & 0 & 1 & 0 & 1 \\
\hline $28 \mathrm{~A}$ & $10 \mathrm{~m}$ & 10 & 76.08 & 10 & 292.1 & 2 & 0 & 0 & 2 \\
\hline $28 \mathrm{~A}$ & $30 \mathrm{~m}$ & 10 & 76.08 & 10 & 292.1 & 2 & 0 & 0 & 2 \\
\hline $29 \mathrm{~A}$ & ROW & 0 & 0 & 0 & 0 & 0 & 0 & 0 & 0 \\
\hline $29 \mathrm{~A}$ & Edge & 10 & 78.16 & 7 & 248.92 & 4 & 1 & 0 & 1 \\
\hline $29 \mathrm{~A}$ & $10 \mathrm{~m}$ & 10 & 90.64 & 11 & 330.2 & 3 & 4 & 0 & 0 \\
\hline
\end{tabular}




\begin{tabular}{|c|c|c|c|c|c|c|c|c|c|}
\hline $29 A$ & $30 \mathrm{~m}$ & 10 & 90.64 & 11 & 330.2 & 3 & 4 & 0 & 0 \\
\hline $30 \mathrm{~A}$ & ROW & 0 & 0 & 0 & 0 & 0 & 0 & 0 & 0 \\
\hline $30 \mathrm{~A}$ & Edge & 6 & 75.56 & 5 & 116.84 & 0 & 8 & 2 & 0 \\
\hline $30 \mathrm{~A}$ & $10 \mathrm{~m}$ & 8 & 75.56 & 3 & 119.38 & 12 & 2 & 0 & 0 \\
\hline $30 \mathrm{~A}$ & $30 \mathrm{~m}$ & 8 & 75.56 & 3 & 119.38 & 12 & 2 & 0 & 0 \\
\hline $31 \mathrm{~A}$ & ROW & 0 & 0 & 0 & 0 & 0 & 0 & 0 & 0 \\
\hline $31 \mathrm{~A}$ & Edge & 5 & 85.18 & 5 & 93.98 & 18 & 0 & 0 & 0 \\
\hline $31 \mathrm{~A}$ & $10 \mathrm{~m}$ & 8 & 91.94 & 6 & 215.9 & 1 & 6 & 1 & 0 \\
\hline $31 \mathrm{~A}$ & $30 \mathrm{~m}$ & 8 & 91.94 & 6 & 215.9 & 1 & 6 & 1 & 0 \\
\hline $32 \mathrm{~A}$ & ROW & 0 & 0 & 0 & 0 & 0 & 0 & 0 & 0 \\
\hline $32 \mathrm{~A}$ & Edge & 5 & 94.28 & 8 & 149.86 & 12 & 3 & 1 & 3 \\
\hline $32 \mathrm{~A}$ & $10 \mathrm{~m}$ & 8 & 89.86 & 10 & 363.22 & 2 & 1 & 0 & 2 \\
\hline $32 \mathrm{~A}$ & $30 \mathrm{~m}$ & 8 & 89.86 & 10 & 363.22 & 2 & 1 & 0 & 2 \\
\hline $33 \mathrm{~A}$ & ROW & 0 & 0 & 0 & 0 & 0 & 0 & 0 & 0 \\
\hline $33 \mathrm{~A}$ & Edge & 6 & 94.8 & 4 & 101.6 & 13 & 0 & 2 & 0 \\
\hline $33 \mathrm{~A}$ & $10 \mathrm{~m}$ & 12 & 94.8 & 6 & 259.08 & 3 & 2 & 0 & 1 \\
\hline $33 \mathrm{~A}$ & $30 \mathrm{~m}$ & 12 & 94.8 & 6 & 259.08 & 3 & 2 & 0 & 1 \\
\hline $34 \mathrm{~A}$ & ROW & 0 & 0 & 0 & 0 & 0 & 0 & 0 & 0 \\
\hline $34 \mathrm{~A}$ & Edge & 6 & 58.66 & 1 & 33.02 & 16 & 4 & 0 & 0 \\
\hline $34 \mathrm{~A}$ & $10 \mathrm{~m}$ & 8 & 84.92 & 5 & 101.6 & 4 & 2 & 5 & 0 \\
\hline $34 \mathrm{~A}$ & $30 \mathrm{~m}$ & 8 & 84.92 & 5 & 101.6 & 4 & 2 & 5 & 0 \\
\hline $35 \mathrm{~A}$ & ROW & 0 & 0 & 0 & 0 & 0 & 0 & 0 & 0 \\
\hline $35 \mathrm{~A}$ & Edge & 0 & 0.16 & 0 & 0 & 0 & 0 & 0 & 0 \\
\hline $35 \mathrm{~A}$ & $10 \mathrm{~m}$ & 0 & 23.04 & 0 & 0 & 43 & 7 & 0 & 0 \\
\hline $35 \mathrm{~A}$ & $30 \mathrm{~m}$ & 0 & 23.04 & 0 & 0 & 43 & 7 & 0 & 0 \\
\hline $36 \mathrm{~A}$ & ROW & 0 & 0 & 0 & 0 & 0 & 0 & 0 & 0 \\
\hline $36 \mathrm{~A}$ & Edge & 0 & 0.16 & 0 & 0 & 0 & 0 & 0 & 0 \\
\hline $36 \mathrm{~A}$ & $10 \mathrm{~m}$ & 0 & 8.22 & 0 & 0 & 0 & 0 & 0 & 0 \\
\hline $36 \mathrm{~A}$ & $30 \mathrm{~m}$ & 0 & 8.22 & 0 & 0 & 0 & 0 & 0 & 0 \\
\hline $37 \mathrm{~A}$ & ROW & 0 & 0 & 0 & 0 & 0 & 0 & 0 & 0 \\
\hline $37 \mathrm{~A}$ & Edge & 0 & 0.16 & 0 & 0 & 0 & 0 & 0 & 0 \\
\hline $37 \mathrm{~A}$ & $10 \mathrm{~m}$ & 0 & 0.16 & 0 & 0 & 0 & 0 & 0 & 0 \\
\hline $37 \mathrm{~A}$ & $30 \mathrm{~m}$ & 0 & 0.16 & 0 & 0 & 0 & 0 & 0 & 0 \\
\hline $38 \mathrm{~A}$ & ROW & 0 & 0 & 0 & 0 & 0 & 0 & 0 & 0 \\
\hline $38 \mathrm{~A}$ & Edge & 0 & 0.16 & 0 & 0 & 0 & 0 & 0 & 0 \\
\hline $38 \mathrm{~A}$ & $10 \mathrm{~m}$ & 10 & 83.62 & 7 & 208.28 & 3 & 0 & 1 & 1 \\
\hline $38 \mathrm{~A}$ & $30 \mathrm{~m}$ & 10 & 83.62 & 7 & 208.28 & 3 & 0 & 1 & 1 \\
\hline 39A & ROW & 0 & 0 & 0 & 0 & 0 & 0 & 0 & 0 \\
\hline $39 \mathrm{~A}$ & Edge & 6 & 66.72 & 1 & 60.96 & 6 & 4 & 0 & 1 \\
\hline 39A & $10 \mathrm{~m}$ & 6 & 87.26 & 6 & 114.3 & 0 & 2 & 4 & 3 \\
\hline $39 \mathrm{~A}$ & $30 \mathrm{~m}$ & 6 & 87.26 & 6 & 114.3 & 0 & 2 & 4 & 3 \\
\hline
\end{tabular}




\begin{tabular}{|c|c|c|c|c|c|c|c|c|c|}
\hline $40 \mathrm{~A}$ & ROW & 0 & 0 & 0 & 0 & 0 & 0 & 0 & 0 \\
\hline $40 \mathrm{~A}$ & Edge & 6 & 57.1 & 1 & 15.24 & 2 & 2 & 3 & 0 \\
\hline $40 \mathrm{~A}$ & $10 \mathrm{~m}$ & 4 & 88.56 & 5 & 223.52 & 7 & 3 & 0 & 1 \\
\hline $40 \mathrm{~A}$ & $30 \mathrm{~m}$ & 4 & 88.56 & 5 & 223.52 & 7 & 3 & 0 & 1 \\
\hline $1 \mathrm{~B}$ & ROW & 0 & 0 & 0 & 0 & 0 & 0 & 0 & 0 \\
\hline 1B & Edge & 0 & 55.54 & 2 & 142.24 & 20 & 1 & 0 & 0 \\
\hline 1B & $10 \mathrm{~m}$ & 6 & 66.98 & 2 & 121.92 & 29 & 2 & 0 & 0 \\
\hline 1B & $30 \mathrm{~m}$ & 6 & 66.98 & 2 & 121.92 & 29 & 2 & 0 & 0 \\
\hline $2 \mathrm{~B}$ & ROW & 0 & 0 & 0 & 0 & 0 & 0 & 0 & 0 \\
\hline $2 \mathrm{~B}$ & Edge & 7 & 59.44 & 5 & 154.94 & 34 & 0 & 0 & 0 \\
\hline $2 B$ & $10 \mathrm{~m}$ & 8 & 73.22 & 13 & 368.3 & 3 & 0 & 1 & 0 \\
\hline $2 B$ & $30 \mathrm{~m}$ & 8 & 73.22 & 13 & 368.3 & 3 & 0 & 1 & 0 \\
\hline $3 B$ & ROW & 0 & 0 & 0 & 0 & 0 & 0 & 0 & 0 \\
\hline $3 B$ & Edge & 5 & 54.76 & 7 & 175.26 & 9 & 0 & 0 & 2 \\
\hline $3 B$ & $10 \mathrm{~m}$ & 7 & 74.26 & 7 & 193.04 & 8 & 0 & 0 & 0 \\
\hline $3 B$ & $30 \mathrm{~m}$ & 7 & 74.26 & 7 & 193.04 & 8 & 0 & 0 & 0 \\
\hline $4 B$ & ROW & 0 & 0 & 0 & 0 & 0 & 0 & 0 & 0 \\
\hline 4B & Edge & 0 & 76.34 & 2 & 60.96 & 25 & 0 & 0 & 0 \\
\hline $4 B$ & $10 \mathrm{~m}$ & 2 & 88.82 & 2 & 119.38 & 22 & 1 & 2 & 0 \\
\hline 4B & $30 \mathrm{~m}$ & 2 & 88.82 & 2 & 119.38 & 22 & 1 & 2 & 0 \\
\hline $5 B$ & ROW & 0 & 0 & 0 & 0 & 0 & 0 & 0 & 0 \\
\hline $5 B$ & Edge & 8 & 61.78 & 4 & 134.62 & 3 & 6 & 2 & 1 \\
\hline $5 B$ & $10 \mathrm{~m}$ & 6 & 82.84 & 4 & 104.14 & 8 & 7 & 0 & 0 \\
\hline $5 B$ & $30 \mathrm{~m}$ & 6 & 82.84 & 4 & 104.14 & 8 & 7 & 0 & 0 \\
\hline $6 B$ & ROW & 0 & 0 & 0 & 0 & 0 & 0 & 0 & 0 \\
\hline $6 B$ & Edge & 8 & 76.86 & 2 & 33.02 & 19 & 0 & 1 & 0 \\
\hline $6 \mathrm{~B}$ & $10 \mathrm{~m}$ & 6 & 80.24 & 1 & 38.1 & 33 & 2 & 0 & 0 \\
\hline $6 \mathrm{~B}$ & $30 \mathrm{~m}$ & 6 & 80.24 & 1 & 38.1 & 33 & 2 & 0 & 0 \\
\hline 7B & ROW & 0 & 0 & 0 & 0 & 0 & 0 & 0 & 0 \\
\hline $7 \mathrm{~B}$ & Edge & 8 & 65.42 & 7 & 182.88 & 10 & 0 & 0 & 1 \\
\hline 7B & $10 \mathrm{~m}$ & 10 & 72.96 & 5 & 132.08 & 33 & 0 & 0 & 0 \\
\hline 7B & $30 \mathrm{~m}$ & 10 & 72.96 & 5 & 132.08 & 33 & 0 & 0 & 0 \\
\hline $8 \mathrm{~B}$ & ROW & 0 & 0 & 0 & 0 & 0 & 0 & 0 & 0 \\
\hline $8 \mathrm{~B}$ & Edge & 4 & 85.44 & 6 & 106.68 & 0 & 0 & 1 & 1 \\
\hline $8 \mathrm{~B}$ & $10 \mathrm{~m}$ & 4 & 88.04 & 9 & 152.4 & 0 & 2 & 2 & 1 \\
\hline $8 \mathrm{~B}$ & $30 \mathrm{~m}$ & 4 & 88.04 & 9 & 152.4 & 0 & 2 & 2 & 1 \\
\hline 9B & ROW & 0 & 0 & 0 & 0 & 0 & 0 & 0 & 0 \\
\hline 9B & Edge & 10 & 69.84 & 2 & 76.2 & 11 & 0 & 0 & 0 \\
\hline $9 B$ & $10 \mathrm{~m}$ & 10 & 86.22 & 6 & 210.82 & 7 & 3 & 0 & 1 \\
\hline 9B & $30 \mathrm{~m}$ & 10 & 86.22 & 6 & 210.82 & 7 & 3 & 0 & 1 \\
\hline $10 \mathrm{~B}$ & ROW & 0 & 0 & 0 & 0 & 0 & 0 & 0 & 0 \\
\hline
\end{tabular}




\begin{tabular}{|c|c|c|c|c|c|c|c|c|c|}
\hline 10B & Edge & 0 & 10.3 & 1 & 86.36 & 0 & 1 & 0 & 0 \\
\hline 10B & $10 \mathrm{~m}$ & 0 & 3.28 & 0 & 0 & 0 & 0 & 0 & 0 \\
\hline 10B & $30 \mathrm{~m}$ & 0 & 3.28 & 0 & 0 & 0 & 0 & 0 & 0 \\
\hline $11 \mathrm{~B}$ & ROW & 0 & 0 & 0 & 0 & 0 & 0 & 0 & 0 \\
\hline $11 \mathrm{~B}$ & Edge & 10 & 66.98 & 4 & 134.62 & 14 & 0 & 0 & 2 \\
\hline $11 \mathrm{~B}$ & $10 \mathrm{~m}$ & 11 & 75.3 & 10 & 330.2 & 5 & 2 & 0 & 0 \\
\hline $11 \mathrm{~B}$ & $30 \mathrm{~m}$ & 11 & 75.3 & 10 & 330.2 & 5 & 2 & 0 & 0 \\
\hline $12 \mathrm{~B}$ & ROW & 0 & 0 & 0 & 0 & 0 & 0 & 0 & 0 \\
\hline $12 \mathrm{~B}$ & Edge & 5 & 49.56 & 3 & 116.84 & 12 & 6 & 0 & 0 \\
\hline $12 \mathrm{~B}$ & $10 \mathrm{~m}$ & 8 & 79.2 & 9 & 271.78 & 24 & 0 & 0 & 0 \\
\hline $12 \mathrm{~B}$ & $30 \mathrm{~m}$ & 8 & 79.2 & 9 & 271.78 & 24 & 0 & 0 & 0 \\
\hline $13 \mathrm{~B}$ & ROW & 0 & 0 & 0 & 0 & 0 & 0 & 0 & 0 \\
\hline $13 \mathrm{~B}$ & Edge & 10 & 74 & 4 & 129.54 & 24 & 3 & 0 & 0 \\
\hline $13 \mathrm{~B}$ & $10 \mathrm{~m}$ & 5 & 82.32 & 8 & 228.6 & 36 & 4 & 0 & 4 \\
\hline $13 \mathrm{~B}$ & $30 \mathrm{~m}$ & 5 & 82.32 & 8 & 228.6 & 36 & 4 & 0 & 4 \\
\hline 14B & ROW & 0 & 0 & 0 & 0 & 0 & 0 & 0 & 0 \\
\hline 14B & Edge & 8 & 80.24 & 5 & 162.56 & 6 & 4 & 1 & 2 \\
\hline $14 \mathrm{~B}$ & $10 \mathrm{~m}$ & 7 & 80.76 & 3 & 83.82 & 8 & 0 & 3 & 0 \\
\hline $14 \mathrm{~B}$ & $30 \mathrm{~m}$ & 7 & 80.76 & 3 & 83.82 & 8 & 0 & 3 & 0 \\
\hline 17B & ROW & 0 & 0 & 0 & 0 & 0 & 0 & 0 & 0 \\
\hline 17B & Edge & 6 & 54.76 & 3 & 73.66 & 4 & 2 & 0 & 0 \\
\hline 17B & $10 \mathrm{~m}$ & 8 & 80.5 & 12 & 287.02 & 22 & 0 & 0 & 0 \\
\hline 17B & $30 \mathrm{~m}$ & 8 & 80.5 & 12 & 287.02 & 22 & 0 & 0 & 0 \\
\hline 18B & ROW & 0 & 0 & 0 & 0 & 0 & 0 & 0 & 0 \\
\hline 18B & Edge & 7 & 55.8 & 3 & 63.5 & 0 & 1 & 3 & 0 \\
\hline $18 \mathrm{~B}$ & $10 \mathrm{~m}$ & 9 & 84.14 & 7 & 203.2 & 9 & 0 & 2 & 0 \\
\hline $18 \mathrm{~B}$ & $30 \mathrm{~m}$ & 9 & 84.14 & 7 & 203.2 & 9 & 0 & 2 & 0 \\
\hline 19B & ROW & 0 & 0 & 0 & 0 & 0 & 0 & 0 & 0 \\
\hline $19 \mathrm{~B}$ & Edge & 4 & 62.56 & 2 & 53.34 & 2 & 0 & 1 & 0 \\
\hline 19B & $10 \mathrm{~m}$ & 8 & 88.04 & 7 & 264.16 & 2 & 1 & 2 & 0 \\
\hline 19B & $30 \mathrm{~m}$ & 8 & 88.04 & 7 & 264.16 & 2 & 1 & 2 & 0 \\
\hline $20 \mathrm{~B}$ & ROW & 0 & 0 & 0 & 0 & 0 & 0 & 0 & 0 \\
\hline $20 \mathrm{~B}$ & Edge & 10 & 59.18 & 7 & 180.34 & 16 & 1 & 1 & 0 \\
\hline $20 \mathrm{~B}$ & $10 \mathrm{~m}$ & 10 & 82.58 & 7 & 233.68 & 21 & 0 & 0 & 0 \\
\hline $20 \mathrm{~B}$ & $30 \mathrm{~m}$ & 10 & 82.58 & 7 & 233.68 & 21 & 0 & 0 & 0 \\
\hline $21 \mathrm{~B}$ & ROW & 0 & 0 & 0 & 0 & 0 & 0 & 0 & 0 \\
\hline $21 \mathrm{~B}$ & Edge & 10 & 56.06 & 3 & 81.28 & 0 & 0 & 0 & 0 \\
\hline $21 \mathrm{~B}$ & $10 \mathrm{~m}$ & 10 & 66.72 & 3 & 83.82 & 0 & 0 & 0 & 0 \\
\hline $21 \mathrm{~B}$ & $30 \mathrm{~m}$ & 10 & 66.72 & 3 & 83.82 & 0 & 0 & 0 & 0 \\
\hline $22 \mathrm{~B}$ & ROW & 0 & 0 & 0 & 0 & 0 & 0 & 0 & 0 \\
\hline $22 \mathrm{~B}$ & Edge & 10 & 69.32 & 7 & 231.14 & 0 & 2 & 2 & 2 \\
\hline
\end{tabular}




\begin{tabular}{|c|c|c|c|c|c|c|c|c|c|}
\hline $22 \mathrm{~B}$ & $10 \mathrm{~m}$ & 10 & 84.14 & 5 & 129.54 & 0 & 1 & 2 & 1 \\
\hline $22 \mathrm{~B}$ & $30 \mathrm{~m}$ & 10 & 84.14 & 5 & 129.54 & 0 & 1 & 2 & 1 \\
\hline $23 \mathrm{~B}$ & ROW & 0 & 0 & 0 & 0 & 0 & 0 & 0 & 0 \\
\hline $23 \mathrm{~B}$ & Edge & 10 & 64.64 & 6 & 180.34 & 0 & 0 & 0 & 0 \\
\hline $23 \mathrm{~B}$ & $10 \mathrm{~m}$ & 10 & 83.1 & 6 & 203.2 & 0 & 0 & 1 & 0 \\
\hline $23 \mathrm{~B}$ & $30 \mathrm{~m}$ & 10 & 83.1 & 6 & 203.2 & 0 & 0 & 1 & 0 \\
\hline $24 \mathrm{~B}$ & ROW & 0 & 0 & 0 & 0 & 0 & 0 & 0 & 0 \\
\hline $24 \mathrm{~B}$ & Edge & 4 & 67.24 & 7 & 165.1 & 2 & 0 & 3 & 0 \\
\hline $24 B$ & $10 \mathrm{~m}$ & 7 & 81.8 & 11 & 327.66 & 3 & 0 & 0 & 0 \\
\hline $24 \mathrm{~B}$ & $30 \mathrm{~m}$ & 7 & 81.8 & 11 & 327.66 & 3 & 0 & 0 & 0 \\
\hline $25 \mathrm{~B}$ & ROW & 0 & 0 & 0 & 0 & 0 & 0 & 0 & 0 \\
\hline $25 \mathrm{~B}$ & Edge & 5 & 68.8 & 5 & 127 & 30 & 0 & 0 & 3 \\
\hline $25 \mathrm{~B}$ & $10 \mathrm{~m}$ & 12 & 78.94 & 8 & 218.44 & 27 & 0 & 0 & 0 \\
\hline $25 \mathrm{~B}$ & $30 \mathrm{~m}$ & 12 & 78.94 & 8 & 218.44 & 27 & 0 & 0 & 0 \\
\hline $26 \mathrm{~B}$ & ROW & 0 & 0 & 0 & 0 & 0 & 0 & 0 & 0 \\
\hline $26 \mathrm{~B}$ & Edge & 8 & 75.82 & 6 & 215.9 & 8 & 0 & 1 & 1 \\
\hline $26 \mathrm{~B}$ & $10 \mathrm{~m}$ & 12 & 88.04 & 6 & 223.52 & 6 & 1 & 0 & 0 \\
\hline $26 \mathrm{~B}$ & $30 \mathrm{~m}$ & 12 & 88.04 & 6 & 223.52 & 6 & 1 & 0 & 0 \\
\hline $27 \mathrm{~B}$ & ROW & 0 & 0 & 0 & 0 & 0 & 0 & 0 & 0 \\
\hline $27 \mathrm{~B}$ & Edge & 0 & 30.84 & 1 & 25.4 & 24 & 1 & 0 & 0 \\
\hline 27B & $10 \mathrm{~m}$ & 10 & 82.84 & 3 & 129.54 & 1 & 4 & 0 & 0 \\
\hline $27 \mathrm{~B}$ & $30 \mathrm{~m}$ & 10 & 82.84 & 3 & 129.54 & 1 & 4 & 0 & 0 \\
\hline $28 \mathrm{~B}$ & ROW & 0 & 0 & 0 & 0 & 0 & 0 & 0 & 0 \\
\hline $28 \mathrm{~B}$ & Edge & 7 & 36.82 & 0 & 0 & 23 & 0 & 0 & 0 \\
\hline $28 \mathrm{~B}$ & $10 \mathrm{~m}$ & 0 & 28.76 & 3 & 60.96 & 38 & 0 & 0 & 0 \\
\hline $28 \mathrm{~B}$ & $30 \mathrm{~m}$ & 0 & 28.76 & 3 & 60.96 & 38 & 0 & 0 & 0 \\
\hline $29 \mathrm{~B}$ & ROW & 0 & 0 & 0 & 0 & 0 & 0 & 0 & 0 \\
\hline $29 \mathrm{~B}$ & Edge & 10 & 49.04 & 8 & 182.88 & 0 & 0 & 0 & 4 \\
\hline $29 \mathrm{~B}$ & $10 \mathrm{~m}$ & 10 & 57.62 & 12 & 304.8 & 17 & 0 & 0 & 1 \\
\hline $29 \mathrm{~B}$ & $30 \mathrm{~m}$ & 10 & 57.62 & 12 & 304.8 & 17 & 0 & 0 & 1 \\
\hline $30 \mathrm{~B}$ & ROW & 0 & 0 & 0 & 0 & 0 & 0 & 0 & 0 \\
\hline $30 \mathrm{~B}$ & Edge & 10 & 45.66 & 6 & 180.34 & 15 & 0 & 0 & 2 \\
\hline $30 \mathrm{~B}$ & $10 \mathrm{~m}$ & 9 & 81.8 & 16 & 426.72 & 7 & 1 & 2 & 1 \\
\hline $30 \mathrm{~B}$ & $30 \mathrm{~m}$ & 9 & 81.8 & 16 & 426.72 & 7 & 1 & 2 & 1 \\
\hline $31 \mathrm{~B}$ & ROW & 0 & 0 & 0 & 0 & 0 & 0 & 0 & 0 \\
\hline $31 \mathrm{~B}$ & Edge & 9 & 86.22 & 3 & 91.44 & 1 & 0 & 0 & 1 \\
\hline $31 \mathrm{~B}$ & $10 \mathrm{~m}$ & 9 & 89.34 & 8 & 294.64 & 45 & 3 & 0 & 0 \\
\hline $31 \mathrm{~B}$ & $30 \mathrm{~m}$ & 9 & 89.34 & 8 & 294.64 & 45 & 3 & 0 & 0 \\
\hline $32 \mathrm{~B}$ & ROW & 0 & 0 & 0 & 0 & 0 & 0 & 0 & 0 \\
\hline $32 \mathrm{~B}$ & Edge & 10 & 67.24 & 2 & 96.52 & 3 & 0 & 0 & 1 \\
\hline $32 \mathrm{~B}$ & $10 \mathrm{~m}$ & 10 & 80.5 & 2 & 86.36 & 9 & 0 & 0 & 0 \\
\hline
\end{tabular}




\begin{tabular}{|c|c|c|c|c|c|c|c|c|c|}
\hline $32 \mathrm{~B}$ & $30 \mathrm{~m}$ & 10 & 80.5 & 2 & 86.36 & 9 & 0 & 0 & 0 \\
\hline $33 B$ & ROW & 0 & 0 & 0 & 0 & 0 & 0 & 0 & 0 \\
\hline $33 B$ & Edge & 0 & 16.02 & 3 & 129.54 & 0 & 0 & 0 & 1 \\
\hline $33 \mathrm{~B}$ & $10 \mathrm{~m}$ & 0 & 24.6 & 0 & 0 & 8 & 0 & 0 & 0 \\
\hline $33 \mathrm{~B}$ & $30 \mathrm{~m}$ & 0 & 24.6 & 0 & 0 & 8 & 0 & 0 & 0 \\
\hline $34 \mathrm{~B}$ & ROW & 0 & 0 & 0 & 0 & 0 & 0 & 0 & 0 \\
\hline $34 \mathrm{~B}$ & Edge & 10 & 77.12 & 8 & 187.96 & 5 & 1 & 1 & 2 \\
\hline 34B & $10 \mathrm{~m}$ & 10 & 85.96 & 9 & 261.62 & 19 & 8 & 0 & 0 \\
\hline 34B & $30 \mathrm{~m}$ & 10 & 85.96 & 9 & 261.62 & 19 & 8 & 0 & 0 \\
\hline $35 \mathrm{~B}$ & ROW & 0 & 0 & 0 & 0 & 0 & 0 & 0 & 0 \\
\hline $35 \mathrm{~B}$ & Edge & 10 & 56.06 & 3 & 86.36 & 18 & 1 & 0 & 0 \\
\hline $35 \mathrm{~B}$ & $10 \mathrm{~m}$ & 10 & 85.7 & 7 & 215.9 & 9 & 0 & 0 & 0 \\
\hline $35 \mathrm{~B}$ & $30 \mathrm{~m}$ & 10 & 85.7 & 7 & 215.9 & 9 & 0 & 0 & 0 \\
\hline $36 \mathrm{~B}$ & ROW & 0 & 0 & 0 & 0 & 0 & 0 & 0 & 0 \\
\hline $36 \mathrm{~B}$ & Edge & 3 & 59.96 & 3 & 55.88 & 17 & 3 & 0 & 1 \\
\hline 36B & $10 \mathrm{~m}$ & 10 & 75.04 & 11 & 314.96 & 37 & 0 & 0 & 0 \\
\hline $36 \mathrm{~B}$ & $30 \mathrm{~m}$ & 10 & 75.04 & 11 & 314.96 & 37 & 0 & 0 & 0 \\
\hline 37B & ROW & 0 & 0 & 0 & 0 & 0 & 0 & 0 & 0 \\
\hline 37B & Edge & 7 & 90.12 & 4 & 129.54 & 0 & 1 & 0 & 1 \\
\hline 37B & $10 \mathrm{~m}$ & 7 & 81.54 & 5 & 149.86 & 17 & 0 & 0 & 0 \\
\hline 37B & $30 \mathrm{~m}$ & 7 & 81.54 & 5 & 149.86 & 17 & 0 & 0 & 0 \\
\hline $38 \mathrm{~B}$ & ROW & 0 & 0 & 0 & 0 & 0 & 0 & 0 & 0 \\
\hline $38 \mathrm{~B}$ & Edge & 0 & 4.84 & 0 & 0 & 14 & 0 & 0 & 0 \\
\hline $38 \mathrm{~B}$ & $10 \mathrm{~m}$ & 2 & 62.3 & 0 & 0 & 25 & 3 & 0 & 0 \\
\hline $38 \mathrm{~B}$ & $30 \mathrm{~m}$ & 2 & 62.3 & 0 & 0 & 25 & 3 & 0 & 0 \\
\hline 39B & ROW & 0 & 0 & 0 & 0 & 0 & 0 & 0 & 0 \\
\hline 39B & Edge & 12 & 56.32 & 2 & 96.52 & 0 & 1 & 0 & 0 \\
\hline 39B & $10 \mathrm{~m}$ & 11 & 76.34 & 6 & 248.92 & 0 & 0 & 0 & 0 \\
\hline 39B & $30 \mathrm{~m}$ & 11 & 76.34 & 6 & 248.92 & 0 & 0 & 0 & 0 \\
\hline 40B & ROW & 0 & 0 & 0 & 0 & 0 & 0 & 0 & 0 \\
\hline 40B & Edge & 10 & 50.08 & 2 & 50.8 & 10 & 3 & 0 & 0 \\
\hline 40B & $10 \mathrm{~m}$ & 11 & 83.36 & 10 & 299.72 & 18 & 1 & 0 & 0 \\
\hline 40B & $30 \mathrm{~m}$ & 11 & 83.36 & 10 & 299.72 & 18 & 1 & 0 & 0 \\
\hline $41 \mathrm{~B}$ & ROW & 0 & 0 & 0 & 0 & 0 & 0 & 0 & 0 \\
\hline 41B & Edge & 8 & 60.48 & 6 & 213.36 & 19 & 0 & 1 & 1 \\
\hline 41B & $10 \mathrm{~m}$ & 8 & 69.84 & 4 & 116.84 & 18 & 2 & 0 & 0 \\
\hline 41B & $30 \mathrm{~m}$ & 8 & 69.84 & 4 & 116.84 & 18 & 2 & 0 & 0 \\
\hline $42 B$ & ROW & 0 & 0 & 0 & 0 & 0 & 0 & 0 & 0 \\
\hline $42 B$ & Edge & 10 & 82.84 & 5 & 119.38 & 7 & 0 & 0 & 1 \\
\hline $42 B$ & $10 \mathrm{~m}$ & 8 & 78.94 & 5 & 104.14 & 17 & 0 & 1 & 0 \\
\hline $42 \mathrm{~B}$ & $30 \mathrm{~m}$ & 8 & 78.94 & 5 & 104.14 & 17 & 0 & 1 & 0 \\
\hline
\end{tabular}


Appendix G: Seed mixes used to reclaim the ROW on the north-western pipeline within the Game Lands 12 site. These mixes were planted in spring 2019. Study sites 4A - 30A were located on this ROW, and the seed mix of each site is shown in appendix A. Each seed mix is numbered 1-16, and the composition of species, percent by weight of each species, and seeding rate (lbs per acre) is shown.

\begin{tabular}{|c|c|c|c|c|}
\hline Mix & Common name & Scientific name & $\% /$ weight & rate \\
\hline \multirow[t]{9}{*}{1} & annual oats - spring & Avena sativa & 61 & 50 \\
\hline & annual ryegrass - fall & loliummultiflorum & 20 & \\
\hline & little bluestem & schizachyrium scoparium & 8 & \\
\hline & indian grass & sorghastrum nutans & 4 & \\
\hline & side oats grama & Bouteloua curtipendula & 2 & \\
\hline & switchgrass & Panicum virgatum & 2 & \\
\hline & black eyed susan & Rudbeckia hirta & 1 & \\
\hline & tall tickseed & Coreopsis tripteris & 1 & \\
\hline & sea oats & uniola paniculata & 2 & \\
\hline \multirow[t]{8}{*}{2} & virginia wildrye & Elymus virginicus & 32 & 15.75 \\
\hline & partridge pea & Chamaecrista fasciculata & 19 & \\
\hline & little bluestem & schizachyrium scoparium & 25 & \\
\hline & indian grass & sorghastrum nutans & 13 & \\
\hline & switchgrass & Panicum virgatum & 6 & \\
\hline & brown eyed susan & Rudbeckia triloba & 2 & \\
\hline & lanceleaf coreopsis & Coreopsis lanceolata & 2 & \\
\hline & purple coneflower & Echinacea purpurea & 2 & \\
\hline \multirow[t]{12}{*}{3} & big bluestem - niagara & Andropogon gerardii & 38 & 8 \\
\hline & eastern gama grass & Tripsacum dactyloides & 25 & \\
\hline & indian grass, PA ecotype & sorghastrum nutans & 19 & \\
\hline & marsh blazing star & Liatris spicata & 5 & \\
\hline & queen annes lace & Daucus carota & 2 & \\
\hline & maximillian sunflower & Helianthus maximilianii & 2 & \\
\hline & smooth blue aster & Aster laevis & 2 & \\
\hline & perennial gaillardia & Gaillardia aristata & 2 & \\
\hline & cup plant & silphium perfoliatum & 2 & \\
\hline & golden alexanders & Zizia aurea & 2 & \\
\hline & ohio spiderwort & Tradescantia ohiensus & 2 & \\
\hline & wild bergamot & Monarda fistulosa & 1 & \\
\hline \multirow[t]{6}{*}{4} & little bluestem, PA ecotype & schizachyrium scoparium & 22 & 8 \\
\hline & broomsedge & Androgen virginicus & 22 & \\
\hline & indiangrass & sorghastrum nutans & 18 & \\
\hline & riverbank wildrye & Elymus riparius & 15 & \\
\hline & purpletop & Tridens flavus & 4 & \\
\hline & tall white beardtongue, PA ecotype & Penstemon digitalis & 2 & \\
\hline
\end{tabular}




\begin{tabular}{|c|c|c|c|c|}
\hline & maximillian sunflower & Helianthus maximilianii & 7 & \\
\hline & swamp milkweed, PA ecotype & Asclepias incarnata & 1 & \\
\hline & common milkweed, PA ecotype & Asclepias syriaca & 1 & \\
\hline & smooth blue aster & Aster laevis & 1 & \\
\hline & new england aster & Aster novae-angliae & 1 & \\
\hline & white avens, PA ecotype & Geum canadense & 1 & \\
\hline & blue false indigo & Baptista australis & 1 & \\
\hline & wild senna & Senna hebecarpa & 1 & \\
\hline & narrow leafed blue-eyed grass & Sisyrinchium angustifolium & 1 & \\
\hline & ohio spiderwort, PA ecotype & Tradescantia ohiensus & 1 & \\
\hline & golden alexanders & Zizia aurea & 1 & \\
\hline & wild bergamot, PA ecotype & Monarda fistulosa & 0.5 & \\
\hline & early goldenrod, PA ecotype & Solidago juncea & 0.2 & \\
\hline & gray goldenrod, PA ecotype & Solidago nemoralis & 0.2 & \\
\hline 5 & side oats grama & Bouteloua curtipendula & 33 & 8 \\
\hline & little bluestem, PA ecotype & schizachyrium scoparium & 33 & \\
\hline & broomsedge & Androgen virginicus & 17 & \\
\hline & purple coneflower & Echinacea purpurea & 4 & \\
\hline & maximillian sunflower & Helianthus maximilianii & 3 & \\
\hline & partridge pea & Chamaecrista fasciculata & 2 & \\
\hline & lance leafed coreopsis & Coreopsis lanceolata & 2 & \\
\hline & black eyed susan & Rudbeckia hirta & 2 & \\
\hline & gray headed coneflower & Ratibida pinnata & 1 & \\
\hline & wild senna & Senna hebecarpa & 1 & \\
\hline 6 & birds-foot trefoil & Lotus corniculatus & 18 & 158 \\
\hline & alsike clover & Trifolium hybridum & 10 & \\
\hline & white clover, Dutch & Trifolium repens & 6 & \\
\hline & white clover, ladino & Trifolium repens & 13 & \\
\hline & medium red clover & Trifolium pratense & 16 & \\
\hline & dwarf essex rape & Brassica napus & 6 & \\
\hline & oats or wheat & & 23 & \\
\hline 7 & little bluestem & schizachyrium scoparium & 40 & 8 \\
\hline & indian grass & sorghastrum nutans & 23 & \\
\hline & wildrye & Elymus spp. & 17 & \\
\hline & maximillian sunflower & Helianthus maximilianii & 2 & \\
\hline & purple coneflower & Echinacea purpurea & 2 & \\
\hline & black eyed susan & Rudbeckia hirta & 2 & \\
\hline & lance leafed coreopsis & Coreopsis lanceolata & 2 & \\
\hline & partridge pea & Chamaecrista fasciculata & 2 & \\
\hline & cup plant & silphium perfoliatum & 2 & \\
\hline & smooth blue aster & Aster laevis & 1 & \\
\hline
\end{tabular}




\begin{tabular}{|c|c|c|c|c|}
\hline & \multirow{5}{*}{$\begin{array}{l}\text { showy trick trefoil } \\
\text { grey headed coneflower } \\
\text { hairy beardtongue } \\
\text { rough gayfeather } \\
\text { wild senna }\end{array}$} & Desmodium canadense & \multicolumn{2}{|l|}{1} \\
\hline & & Ratibida pinnata & \multicolumn{2}{|l|}{1} \\
\hline & & Penstemon hirsutus & \multicolumn{2}{|l|}{1} \\
\hline & & Liatris aspera & \multicolumn{2}{|l|}{1} \\
\hline & & Senna hebecarpa & 1 & \\
\hline \multirow[t]{10}{*}{8} & side oats grama & Bouteloua curtipendula & 33 & 8 \\
\hline & little bluestem & schizachyrium scoparium & 33 & \\
\hline & broomsedge & Androgen virginicus & 17 & \\
\hline & purple coneflower & Echinacea purpurea & 4 & \\
\hline & maximillian sunflower & Helianthus maximilianii & 3 & \\
\hline & partridge pea & Chamaecrista fasciculata & 2 & \\
\hline & lance leafed coreopsis & Coreopsis lanceolata & 2 & \\
\hline & black eyed susan & Rudbeckia hirta & 2 & \\
\hline & grey headed coneflower & Ratibida pinnata & 1 & \\
\hline & wild senna & Senna hebecarpa & 1 & \\
\hline
\end{tabular}

$9 \quad 2+6$

$103+6$

$114+6$

$125+6$

$136+8$

14 wetland

15 virginia wildrye

Elymus virginicus

22

20

big bluestem - niagara

Andropogon gerardii

16

indiangrass

sorghastrum nutans

15

switchgrass

Panicum virgatum

14

partridge pea

Chamaecrista fasciculata 6

autumn bentgrass

Agrostis perennans

6

blue vervain

oxeye sunflower

Verbena hastata

6

Heliopsis helianthoides 3

black eyed susan

Rudbeckia hirta 3

boneset

Eupatorium perfoliatum

2

giant ironweed

Vernonia angustifolia

2

soft rush

Juncus effusus

2

swamp sunflower

Helianthus angustifolius 1

blue false indigo

joe pye weed

Baptisiaaustralis

1

Eupatorium fistulosum 1

Lobelia siphilitca 1

great blue lobelia

wild bergamot

Monarda fistulosa

1

16 Alsike clover

Trifolium hybridum

7

white dutch clover

Trifolium repens 
ladino clover

medium red clover

aspen seedlings

dwarf essex rape

oats or wheat
Trifolium repens

Trifolium pratense

Populus tremuloides

Brassica napus
7

7

0

1 
Appendix H: Butterfly species present in Bradford and Lycoming counties of Pennsylvania from Butterflies of Pennsylvania (Monroe and Wright 2017). Visually similar species which are difficult to distinguish from photographs were grouped together and counted as one species when encountered (ID Group).

\begin{tabular}{|c|c|c|}
\hline Species & scientific name & $\begin{array}{l}\text { ID } \\
\text { group }\end{array}$ \\
\hline Pipevine swallowtail & Battus philenor & 1 \\
\hline black swallowtail & Papilio polyxenes & 2 \\
\hline Giant Swallowtail & Papilio cresphontes & 3 \\
\hline $\begin{array}{l}\text { Eastern Tiger Swallowtail } \\
\text { Canadian Tiger }\end{array}$ & Papilio glaucus & 4 \\
\hline Swallowtail & Papilio canadensis & 4 \\
\hline SpiceBush Swallowtail & Papilio troilus & 5 \\
\hline West Virginia White & Pieris virginiensis & 6 \\
\hline Cabbage White & Pieris rapae & 7 \\
\hline Clouded Sulphur & Colias philodice & 8 \\
\hline Orange Sulphur & Colias eurytheme & 8 \\
\hline Little Yellow & Pyrisitia lisa & 8 \\
\hline Harvester & Feniseca tarquinius & 9 \\
\hline American Copper & Lycaena phlaeas & 10 \\
\hline Bronze Copper & Lycaena hyllus & 10 \\
\hline Bog Copper & Lycaena epixanthe & 11 \\
\hline Coral Hairstreak & Satyrium titus & 12 \\
\hline Acadian Hairstreak & Satyrium acadica & 12 \\
\hline Edwards Hairstreak & Satyrium edwardsii & 12 \\
\hline Banded Hairstreak & Satyrium calanus & 12 \\
\hline Hickory Hairstreak & Satyrium caryaevorus & 12 \\
\hline Striped Hairstreak & Satyrium liparops & 12 \\
\hline Oak Hairstreak & Satyrium favonius & 12 \\
\hline Brown Elfin & Callophrys augustinus & 13 \\
\hline Frosted Elfin & Callophrys irus & 13 \\
\hline Eastern Pine Elfin & Callophrys niphon & 13 \\
\hline Gray Hairstreak & Strymon melinus & 14 \\
\hline Eastern Tailed Blue & Cupido comyntas & 15 \\
\hline Northern Spring Azure & Celastrina lucia & 16 \\
\hline Summer Azure & Celastrina neglecta & 17 \\
\hline Cherry Gall Azure & Celastrina serotina & 17 \\
\hline American Snout & Libytheana carinenta & 18 \\
\hline Monarch & Danaus plexippus & 19 \\
\hline Variegated Fritillary & Euptoieta claudia & 20 \\
\hline Great Spangled Fritillary & Speyeria cybele & 21 \\
\hline
\end{tabular}




\begin{tabular}{|c|c|c|}
\hline Aphrodite Fritillary & Speyeria aphrodite & 21 \\
\hline Atlantis Fritillary & Speyeria atlantis & 21 \\
\hline Regal Fritillary & Speyeria idalia & 21 \\
\hline Silver-bordered fritillary & Boloria selene & 21 \\
\hline Meadow fritillary & Boloria bellona & 21 \\
\hline Harris' checkerspot & Chlosyne harrisii & 22 \\
\hline Baltimore checkerspot & Euphydryas phaeton & 22 \\
\hline Pearl Crescent & Phyciodes tharos & 23 \\
\hline Northern Crescent & Phyciodes cocyta & 23 \\
\hline Common Buckeye & Junonia coenia & 24 \\
\hline Question Mark & Polygonia interrogationis & 25 \\
\hline Eastern Comma & Polygonia comma & 25 \\
\hline Green Comma & Polygonia faunus & 25 \\
\hline Gray Comma & Polygonia progne & 25 \\
\hline Compton Tortoiseshell & Nymphalis l-album & 25 \\
\hline Morning Cloak & Nymphalis antiopa & 26 \\
\hline Milbert's Tortoiseshell & Aglais milberti & 27 \\
\hline American Lady & Vanessa virginiensis & 28 \\
\hline Painted Lady & Vanessa cardui & 29 \\
\hline Red Admiral & Vanessa atalanta & 30 \\
\hline White Admiral & Limenitis arthemis arthemis & 31 \\
\hline Red-spotted Purple & Limenitis arthemis astyanax & 32 \\
\hline Viceroy & Limenitis archippus & 33 \\
\hline Hackberry Emperor & Asterocampa celtis & 34 \\
\hline Tawny Emperor & Asterocampa clyton & 35 \\
\hline Northern Pearly-Eye & Lethe anthedon & 36 \\
\hline Eyed Brown & Lethe eurydice & 36 \\
\hline Appalachian Brown & Leethe appalachia & 36 \\
\hline Little Wood Satyr & Megisto cymela & 37 \\
\hline Common Ringlet & Coenonympha tullia & 38 \\
\hline Common Wood Nymph & Cercyonia pegala & 39 \\
\hline Silver-spotted Skipper & Epargyreus clarus & 40 \\
\hline Hoary Edge & Achalarus lyciades & 40 \\
\hline Northern Cloudywing & Thorybes pylades & 41 \\
\hline Dreamy Duskywing & Erynnis icelus & 41 \\
\hline Sleepy Duskywing & Erynnis brizo & 41 \\
\hline Juvenal's Duskywing & Erynnis juvenalis & 41 \\
\hline Mottled Duskywing & Erynnis martialis & 41 \\
\hline Wild Indigo Duskywing & Erynnis baptisiae & 41 \\
\hline Common Sootywing & Pholisora catullus & 41 \\
\hline
\end{tabular}


common checkered-

\begin{tabular}{lll} 
skipper & Pyrgus communis & 41 \\
\hline Least Skipper & Ancyloxypha numitor & 42 \\
European Skipper & Thymelicus lineola & 42 \\
Leonard's Skipper & Hesperia leonardus & 42 \\
Cobweb Skipper & Hesperia metea & 42 \\
Indian Skipper & Hesperia sassacus & 42 \\
Peck's Skipper & Polites peckius & 42 \\
Tawny-edged Skipper & Polites themistocles & 42 \\
Crossline Skipper & Polites origenes & 42 \\
Long Dash & Polites mystic & 42 \\
Little Glassywing & Pompeius verna & 42 \\
Northern Broken-Dash & Wallengrenia egeremet & 42 \\
Delaware Skipper & Anatrytine logan & 42 \\
Zabulon Skipper & Poanes zabulon & 42 \\
Hobomok Skipper & Poanes hobomok & 42 \\
Dion Skipper & Euphyes dion & 42 \\
Two-Spotted Skipper & Euphyes bimacula & 42 \\
Dun Skippper & Euphyes vestris & 42 \\
Common Roadside- & & 42 \\
Skipper & Amblyscirtes vialis &
\end{tabular}


Appendix I: Pollinator encounters during each survey. Data are broken up by site, survey, and year. Abundance was not recorded during 2019, but was in 2020. ETB is an abbreviation of Eastern tailed blue. Bees were not separated by species or group.

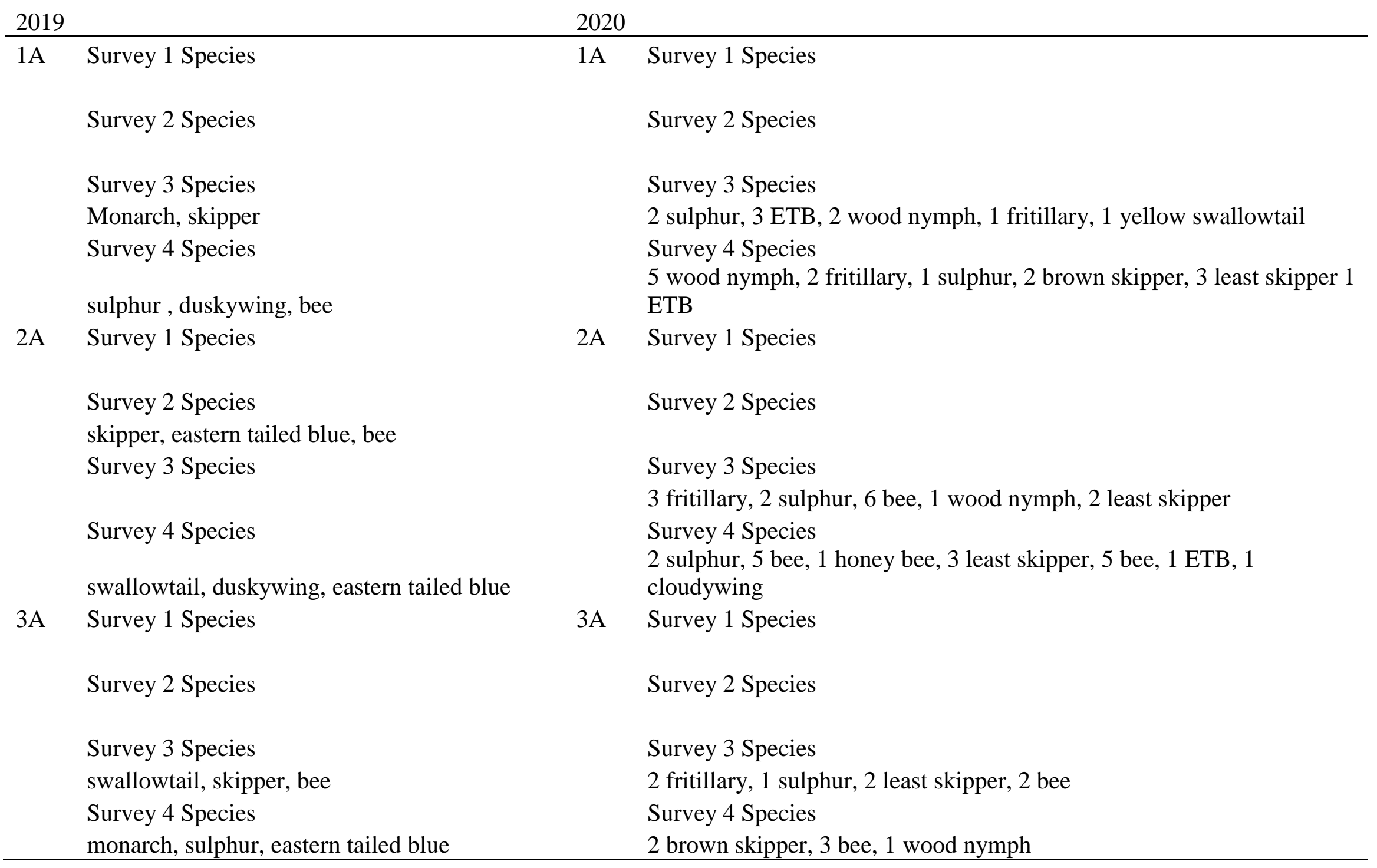




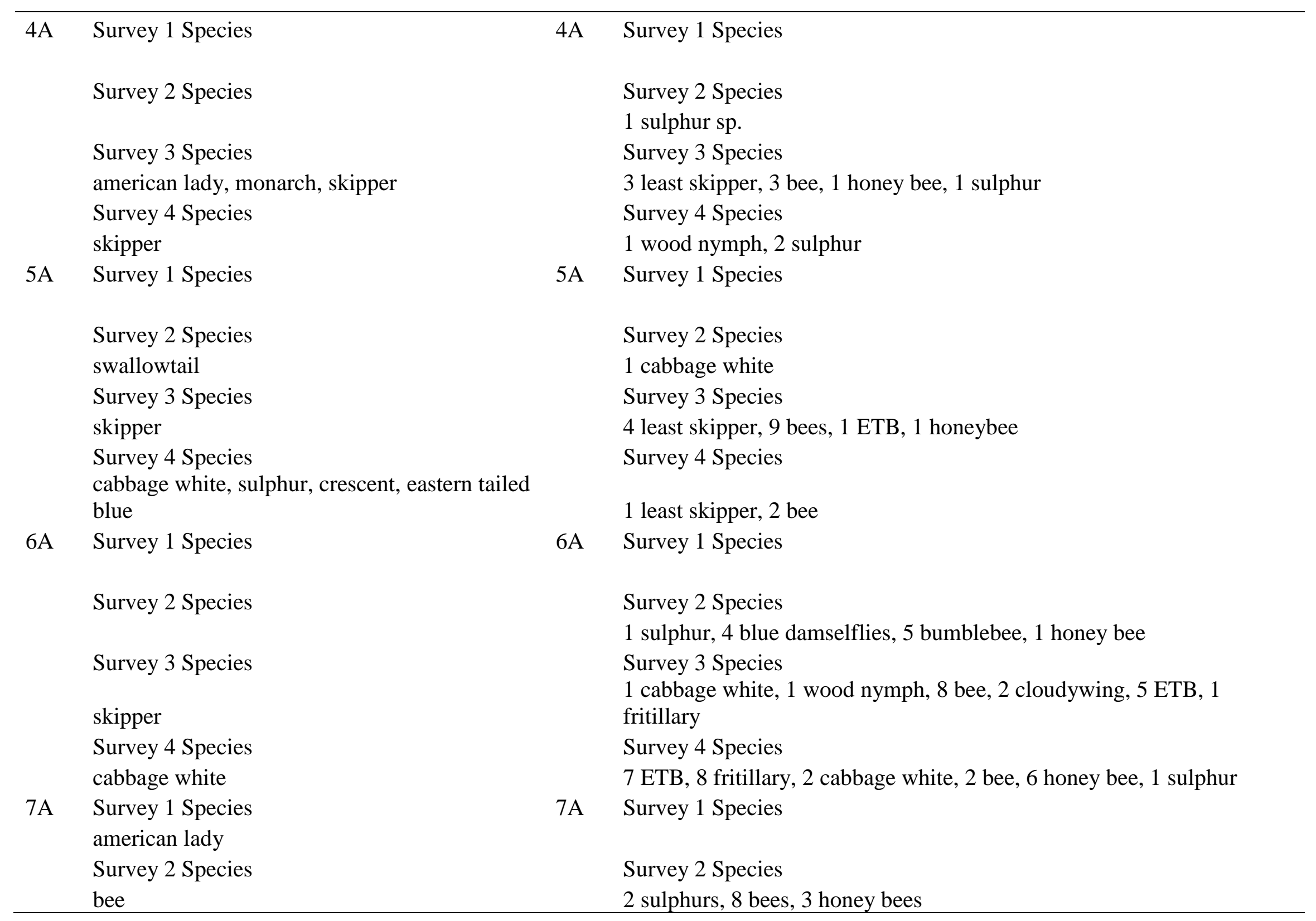




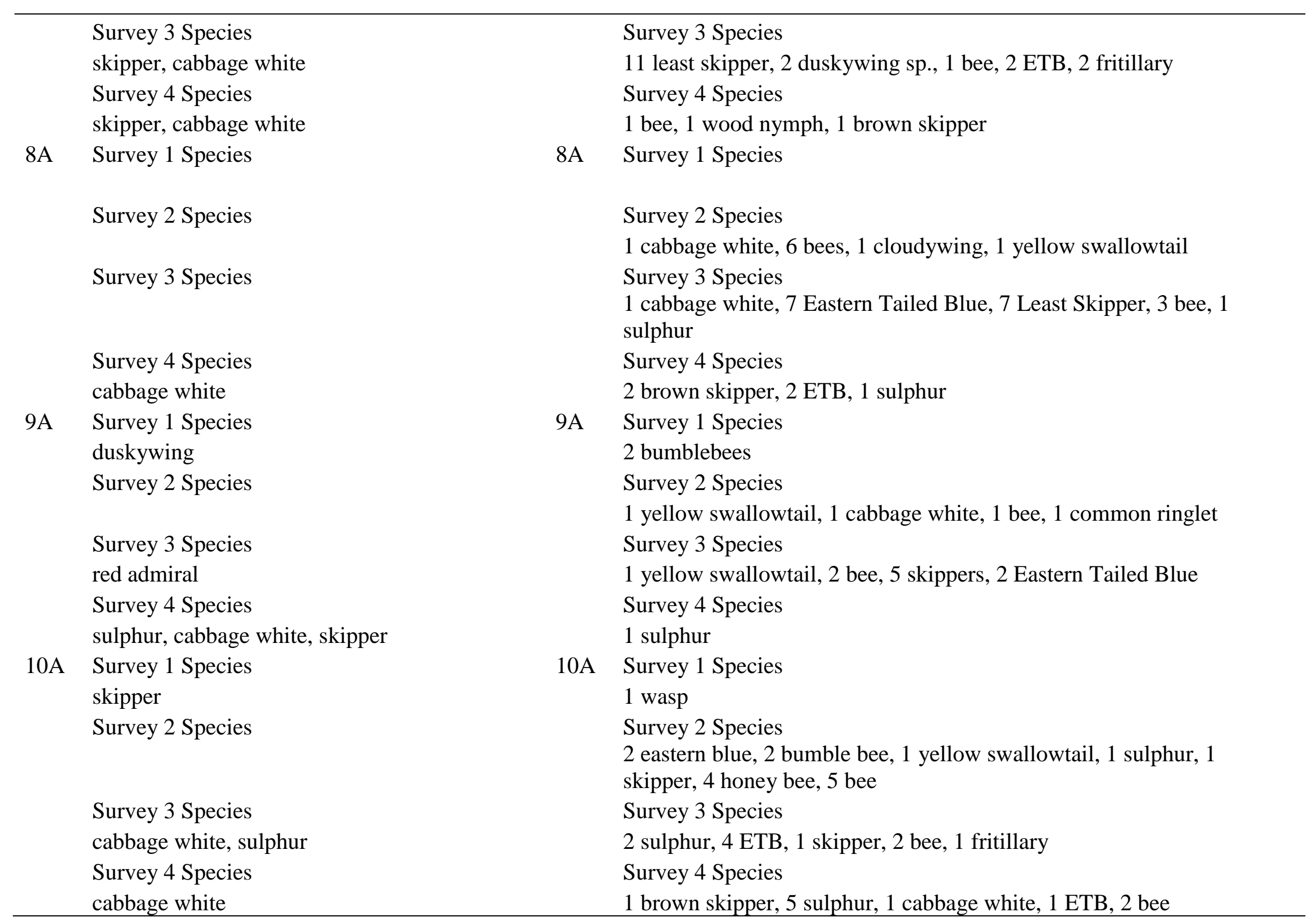




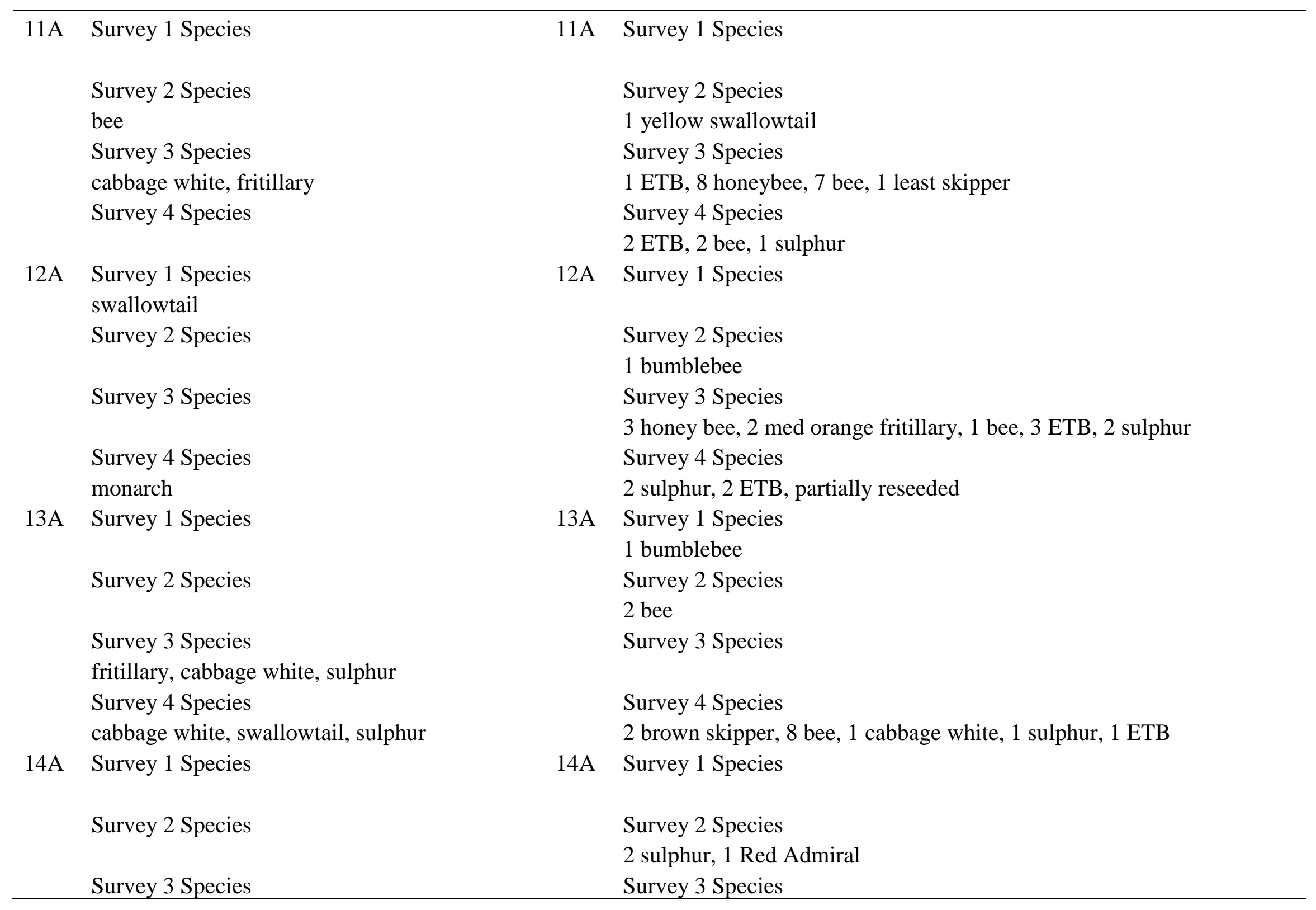




\begin{tabular}{|c|c|c|c|}
\hline & & & 2 bee, 1 sulphur, 1 ETB \\
\hline & Survey 4 Species & & Survey 4 Species \\
\hline & cabbage white, sulphur, swallowtail & & \\
\hline \multirow[t]{8}{*}{$15 \mathrm{~A}$} & Survey 1 Species & $15 \mathrm{~A}$ & Survey 1 Species \\
\hline & red admiral, bee & & \\
\hline & Survey 2 Species & & Survey 2 Species \\
\hline & & & 1 sulphur \\
\hline & Survey 3 Species & & Survey 3 Species \\
\hline & american lady & & 12 bee, 3 least skipper, 3 sulphur, 4 fritillary, 1 honey bee, 1 ETB, \\
\hline & Survey 4 Species & & Survey 4 Species \\
\hline & $\begin{array}{l}\text { american lady, skipper, cabbage white, eastern } \\
\text { tailed blue, sulhpur, bee }\end{array}$ & & 6 ETB, 3 sulphur, 1 bee, $1 \mathrm{lg}$ fritillary \\
\hline \multirow[t]{8}{*}{$16 \mathrm{~A}$} & Survey 1 Species & $16 \mathrm{~A}$ & Survey 1 Species \\
\hline & & & 1 sulphur sp. \\
\hline & Survey 2 Species & & Survey 2 Species \\
\hline & & & 2 bumble bee \\
\hline & Survey 3 Species & & Survey 3 Species \\
\hline & cabbage white & & 10 bee, 4 fritillary, 4 least skipper, 3 honey bee, 1 ETB, 1 sulphur \\
\hline & Survey 4 Species & & Survey 4 Species \\
\hline & cabbage white, sulphur & & 3 sulphur, 5 bee, 1 ETB, 2 brown skipper, 1 cabbage white \\
\hline \multirow[t]{7}{*}{$17 \mathrm{~A}$} & Survey 1 Species & $17 \mathrm{~A}$ & Survey 1 Species \\
\hline & Survey 2 Species & & Survey 2 Species \\
\hline & bee & & 1 bumblebee, 1 swallowtail \\
\hline & Survey 3 Species & & Survey 3 Species \\
\hline & & & 4 fritillary, 1 sulphur, 2 ETB, 3 bee \\
\hline & Survey 4 Species & & Survey 4 Species \\
\hline & & & $\begin{array}{l}1 \text { yellow swallowtail, } 4 \text { sulphur, } 4 \text { fritillary, } 7 \text { brown skipper, } 2 \text { ETB, } 6 \\
\text { bee, } 1 \text { sweat bee, } 3 \text { least skipper }\end{array}$ \\
\hline $18 \mathrm{~A}$ & Survey 1 Species & $18 \mathrm{~A}$ & Survey 1 Species \\
\hline
\end{tabular}


Survey 2 Species

Survey 3 Species

cabbage white, skipper, bee

Survey 4 Species

cabbage white, skipper, bee

19A Survey 1 Species

Survey 2 Species

Survey 3 Species

sulphur, fritillary

Survey 4 Species

cabbage white

20A Survey 1 Species

Survey 2 Species

eastern tailed blue, duskywing

Survey 3 Species

cabbage white, skipper

Survey 4 Species

cabbage white, sulphur, bee

21A Survey 1 Species

Survey 2 Species

Survey 3 Species
Survey 2 Species

1 sulphur, 1 least skipper, 1 yellow swallowtail

Survey 3 Species

3 ETB, 4 bee, 2 fritillary, 2 least skipper

Survey 4 Species

1 sulphur, 1 sweat bee, 1 monarch, 7 fritillary, 17 bee, 2 brown skipper, thistle

19A Survey 1 Species

Survey 2 Species

1 bumblebee, 1 cabbage white

Survey 3 Species

1 fritillary, 12 bees, 1 honey bee

Survey 4 Species

2 fritillary, 2 bee, 6 ETB, 1 sulphur

20A Survey 1 Species

1 sulphur sp., 1 bumblebee

Survey 2 Species

1 sulphur, 15 bee, 6 honey bee, 1 american lady

Survey 3 Species

5 bee, 2 fritillary, 2 least skipper, 2 sulphur, 2 ETB, 4 honeybee Survey 4 Species

1 ETB, 2 sulphur, 3 honey bee, 1 brown skipper, 2 fritillary, 1 bee

21A Survey 1 Species

Survey 2 Species

2 sulphurs, 1 honey bee

Survey 3 Species 


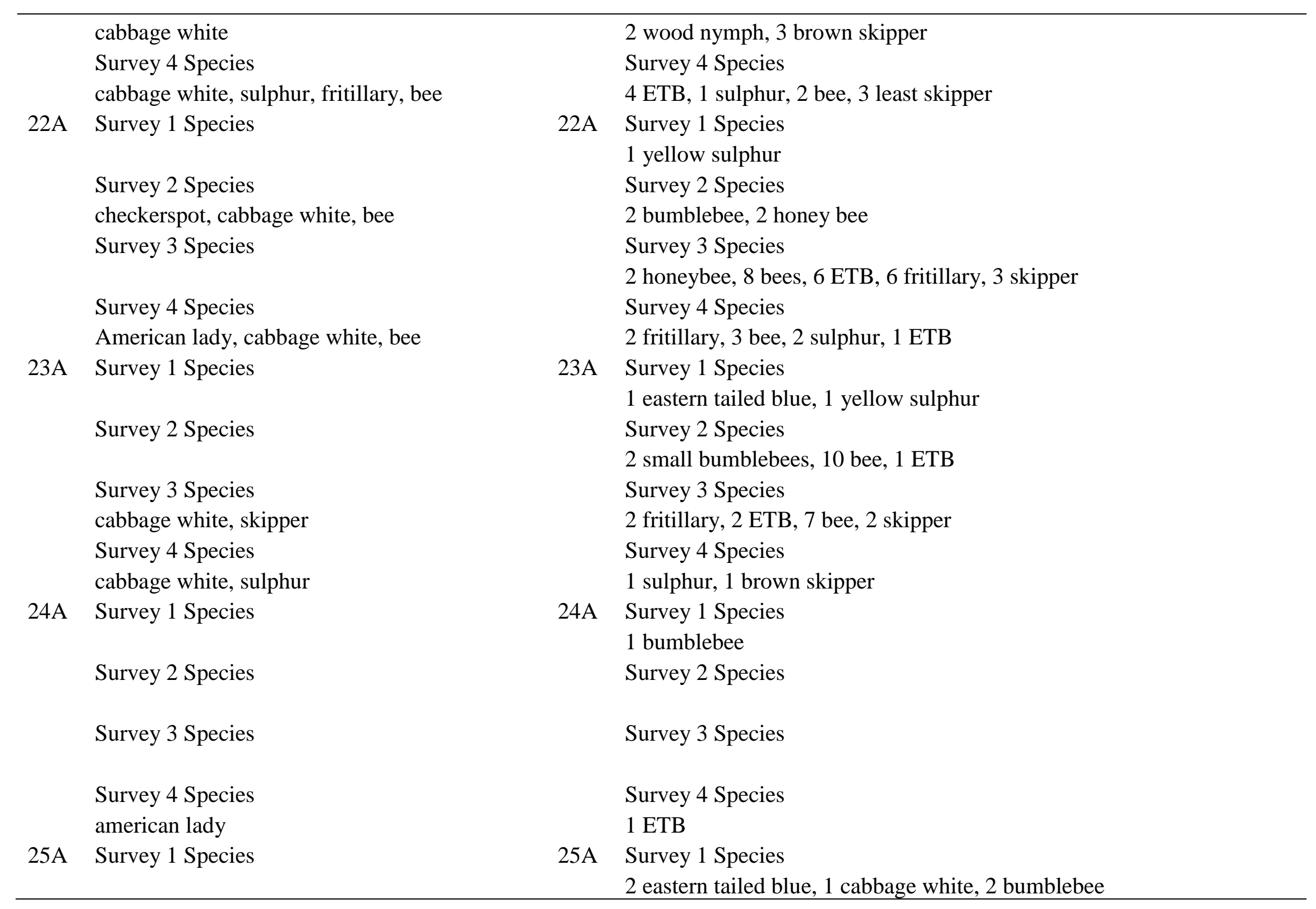




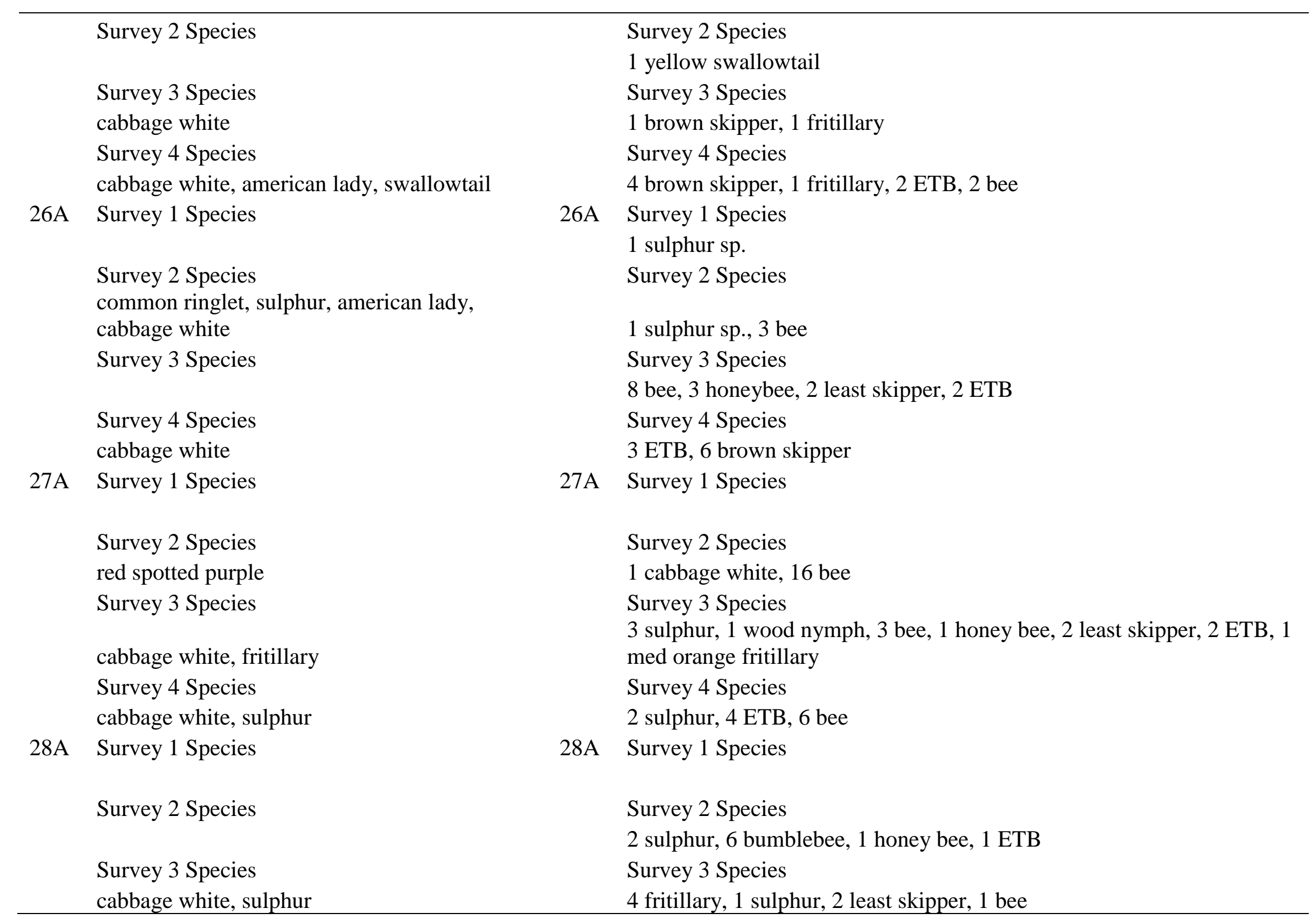




\begin{tabular}{|c|c|c|c|}
\hline \multirow{5}{*}{$29 \mathrm{~A}$} & \multirow{3}{*}{$\begin{array}{l}\text { Survey } 4 \text { Species } \\
\text { cabbage white, sulphur } \\
\text { Survey } 1 \text { Species }\end{array}$} & \multirow{4}{*}{$29 \mathrm{~A}$} & \multirow{3}{*}{$\begin{array}{l}\text { Survey } 4 \text { Species } \\
5 \text { sulphur, } 1 \text { ETB, } 1 \text { cabbage white } \\
\text { Survey } 1 \text { Species }\end{array}$} \\
\hline & & & \\
\hline & & & \\
\hline & Survey 2 Species & & Survey 2 Species \\
\hline & Survey 3 Species & & Survey 3 Species \\
\hline \multirow{4}{*}{$30 \mathrm{~A}$} & Survey 4 Species & & Survey 4 Species \\
\hline & sulphur & & 1 cabbage white, 1 american lady, 1 ETB \\
\hline & Survey 1 Species & $30 \mathrm{~A}$ & Survey 1 Species \\
\hline & Survey 2 Species & & Survey 2 Species \\
\hline \multirow{10}{*}{$31 \mathrm{~A}$} & red admiral, bee & & 1 sulphur, 2 bumblebee, 1 honeybee \\
\hline & Survey 3 Species & & Survey 3 Species \\
\hline & cabbage white & & 3 bee, 2 ETB, 1 fritillary \\
\hline & Survey 4 Species & & Survey 4 Species \\
\hline & cabbage white, sulphur, bee & & 1 fritillary, 2 bee \\
\hline & $\begin{array}{l}\text { Survey } 1 \text { Species } \\
\text { sulphur, american lady }\end{array}$ & $31 \mathrm{~A}$ & Survey 1 Species \\
\hline & Survey 2 Species & & Survey 2 Species \\
\hline & & & 2 honey bee, 1 eastern tailed blue \\
\hline & Survey 3 Species & & Survey 3 Species \\
\hline & fritillary, skipper & & 2 sulphur, 2 ETB \\
\hline \multirow{5}{*}{$32 \mathrm{~A}$} & Survey 4 Species & & Survey 4 Species \\
\hline & monarch, sulphur, bee & & 1 sulphur, 1 sweat bee \\
\hline & Survey 1 Species & $32 \mathrm{~A}$ & Survey 1 Species \\
\hline & black swallowtail & & \\
\hline & Survey 2 Species & & Survey 2 Species \\
\hline
\end{tabular}




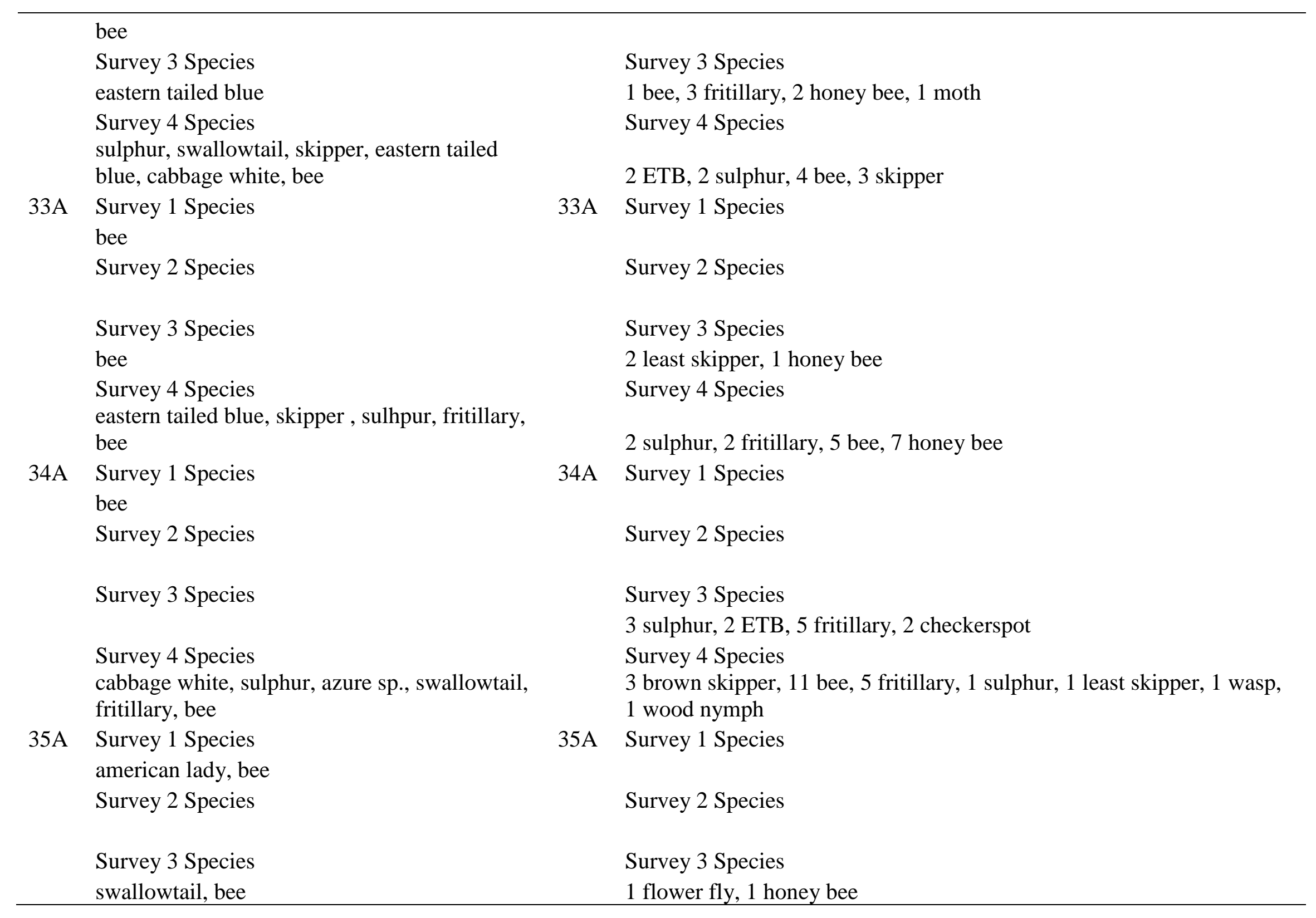




\begin{tabular}{|c|c|c|c|}
\hline & $\begin{array}{l}\text { Survey } 4 \text { Species } \\
\text { bee }\end{array}$ & & Survey 4 Species \\
\hline \multirow[t]{5}{*}{$36 \mathrm{~A}$} & $\begin{array}{l}\text { Survey } 1 \text { Species } \\
\text { azure spp., bee }\end{array}$ & $36 \mathrm{~A}$ & Survey 1 Species \\
\hline & Survey 2 Species & & Survey 2 Species \\
\hline & red spotted purple, skipper, bee & & 1 cabbage white, 1 sulphur \\
\hline & Survey 3 Species & & $\begin{array}{l}\text { Survey } 3 \text { Species } \\
1 \text { yellow swallowtail, } 2 \text { sulphur, } 1 \text { wood nymph, } 1 \text { sweat bee, } 1 \text { brown }\end{array}$ \\
\hline & $\begin{array}{l}\text { Survey } 4 \text { Species } \\
\text { american lady, sulphur, black swallowtail, } \\
\text { eastern tailed blue }\end{array}$ & & $\begin{array}{l}\text { Survey } 4 \text { Species } \\
1 \text { monarch, } 5 \text { bee, } 2 \text { least skipper }\end{array}$ \\
\hline \multirow[t]{4}{*}{$37 \mathrm{~A}$} & $\begin{array}{l}\text { Survey } 1 \text { Species } \\
\text { cabbage white, bee }\end{array}$ & $37 \mathrm{~A}$ & Survey 1 Species \\
\hline & skipper, cabbage white, sulphur, fritillary & & 5 bees, 1 least skipper \\
\hline & Survey 4 Species & & Survey 4 Species \\
\hline & sootywing, sulphur, azure spp. & & 1 bee, 1 wood nymph, 1 monarch \\
\hline \multirow[t]{5}{*}{$38 \mathrm{~A}$} & $\begin{array}{l}\text { Survey } 1 \text { Species } \\
\text { bee }\end{array}$ & $38 \mathrm{~A}$ & Survey 1 Species \\
\hline & $\begin{array}{l}\text { Survey } 2 \text { Species } \\
\text { swallowtail, skipper, painted lady, american } \\
\text { lady, red spotted purple, bee }\end{array}$ & & Survey 2 Species \\
\hline & Survey 3 Species & & Survey 3 Species \\
\hline & swallowtail, eastern tailed blue, skipper, bee & & 1 sulphur, 4 ETB, 1 bee, 1 fritillary \\
\hline & Survey 4 Species & & Survey 4 Species \\
\hline
\end{tabular}




\begin{tabular}{|c|c|c|c|}
\hline & \multicolumn{2}{|l|}{ cabbage white, bee } & 1 cabbage white, 1 flower fly \\
\hline & \multirow{2}{*}{\multicolumn{2}{|c|}{ Survey 2 Species }} & Survey 2 Species \\
\hline & & & 1 honey bee, 1 cabbage white \\
\hline & \multicolumn{2}{|l|}{ Survey 3 Species } & Survey 3 Species \\
\hline & & & 3 brown skipper, 1 sulphur \\
\hline & \multicolumn{2}{|l|}{$\begin{array}{l}\text { Survey } 4 \text { Species } \\
\text { cabbage white, sulphur, skipper, swallowtail, }\end{array}$} & Survey 4 Species \\
\hline & \multicolumn{2}{|l|}{ monarch } & 2 monarch, 2 fritillary, 1 bee, 3 brown skipper, 1 sulphur \\
\hline \multirow[t]{7}{*}{$40 \mathrm{~A}$} & \multirow[t]{2}{*}{ Survey 1 Species } & \multirow[t]{3}{*}{$40 \mathrm{~A}$} & Survey 1 Species \\
\hline & & & 1 red admiral \\
\hline & Survey 2 Species & & Survey 2 Species \\
\hline & \multicolumn{2}{|l|}{ Survey 3 Species } & Survey 3 Species \\
\hline & \multicolumn{2}{|l|}{ cabbage white, sulphur } & 2 least skipper, 1 fritillary \\
\hline & \multicolumn{2}{|l|}{ Survey 4 Species } & Survey 4 Species \\
\hline & \multicolumn{2}{|l|}{ cabbage white, sulphur, azure spp. } & 3 least skipper, 4 bee, 1 wood nymph, 1 yellow swallowtail \\
\hline \multirow[t]{6}{*}{$1 \mathrm{~B}$} & Survey 1 Species & $1 \mathrm{~B}$ & Survey 1 Species \\
\hline & \multicolumn{2}{|l|}{ Survey 2 Species } & Survey 2 Species \\
\hline & \multicolumn{2}{|l|}{ Survey 3 Species } & Survey 3 Species \\
\hline & \multicolumn{2}{|l|}{ monarch, skipper, bee } & $\begin{array}{l}1 \text { wood nymph, } 18 \text { bee, } 2 \text { yellow swallowtail, } 1 \text { ETB, } 4 \text { honey bee, } 1 \\
\text { brown skipper }\end{array}$ \\
\hline & \multirow{2}{*}{\multicolumn{2}{|c|}{ monarch, swallowtail, duskywing, sulphur, bee }} & Survey 4 Species \\
\hline & & & $\begin{array}{l}32 \text { bee, } 2 \text { checkerspot, } 3 \text { black swallowtail, } 2 \text { sulphur, } 3 \text { honey bee, } 3 \\
\text { monarch, } 1 \text { wood nymph, } 2 \text { yellow swallowtail, } 1 \text { cloudywing, invasive } \\
\text { pea plant thing }\end{array}$ \\
\hline 2B & $\begin{array}{l}\text { Survey } 1 \text { Species } \\
\text { crescent, skipper, american lady, red admiral, } \\
\text { bee }\end{array}$ & 2B & Survey 1 Species \\
\hline
\end{tabular}




\begin{tabular}{|c|c|c|c|}
\hline & Survey 2 Species & & Survey 2 Species \\
\hline & little wood satyr & & 1 yellow swallowtail, 2 wood nymph \\
\hline & Survey 3 Species & & Survey 3 Species \\
\hline & red admiral & & 3 wood nymph, 1 cloudywing, 1 least skipper, 1 brown skipper \\
\hline & Survey 4 Species & & Survey 4 Species \\
\hline & $\begin{array}{l}\text { monarch, common ringlet, black swallowtail, } \\
\text { azure spp., bee }\end{array}$ & & 3 ETB, 2 wood nymph, 1 black swallowtail \\
\hline \multirow{6}{*}{$3 \mathrm{~B}$} & Survey 2 Species & & Survey 2 Species \\
\hline & little wood satyr & & 1 bumblebee \\
\hline & Survey 3 Species & & Survey 3 Species \\
\hline & & & 2 wood nymph \\
\hline & Survey 4 Species & & Survey 4 Species \\
\hline & bee & & 1 ETB, 1 sulphur, 1 bee \\
\hline \multirow[t]{4}{*}{$4 \mathrm{~B}$} & $\begin{array}{l}\text { Survey } 1 \text { Species } \\
\text { crescent, duskywing, fritillary }\end{array}$ & 4B & Survey 1 Species \\
\hline & $\begin{array}{l}\text { Survey } 2 \text { Species } \\
\text { crescent }\end{array}$ & & Survey 2 Species \\
\hline & crescent, skipper, monarch, fritillary, bee & & $\begin{array}{l}\text { Survey } 3 \text { Species } \\
29 \text { bees, } 3 \text { sulphur, } 1 \text { ETB, } 2 \text { yellow swallowtail, } 2 \text { duskywing, } 1 \text { med } \\
\text { med orange fritillary, } 2 \text { honey bee, } 1 \text { monarchlots of thistle and } \\
\text { milkweed }\end{array}$ \\
\hline & $\begin{array}{l}\text { Survey } 4 \text { Species } \\
\text { monarch, duskywing, crescent, bee }\end{array}$ & & $\begin{array}{l}\text { Survey } 4 \text { Species } \\
4 \text { monarch, } 2 \text { ETB, } 2 \text { brown skipper, } 35 \text { bees, } 7 \text { honey bee, } 1 \\
\text { cloudywing, } 2 \text { yellow swallowtail, } 1 \text { checkerspot }\end{array}$ \\
\hline \multirow[t]{3}{*}{$5 B$} & $\begin{array}{l}\text { Survey } 1 \text { Species } \\
\text { painted lady, swallowtail, fritillary, bee }\end{array}$ & $5 B$ & Survey 1 Species \\
\hline & Survey 2 Species & & Survey 2 Species \\
\hline & cabbage white, skipper, bee & & 1 duskywing, wood satyr \\
\hline
\end{tabular}




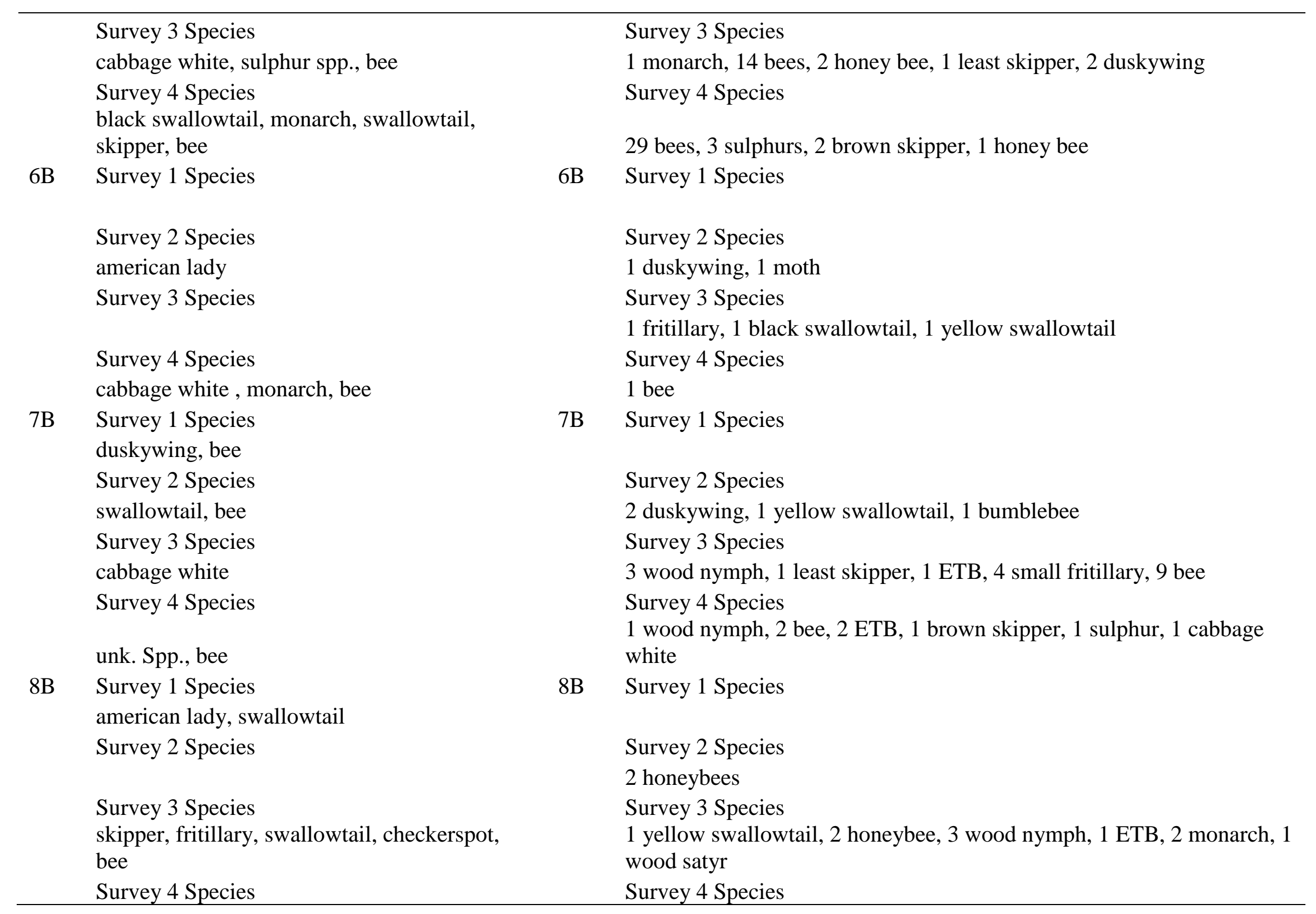




\begin{tabular}{|c|c|c|c|}
\hline & $\begin{array}{l}\text { monarch, swallowtail, common wood nymph, } \\
\text { eyed brown }\end{array}$ & & 13 bee, 1 monarch, 1 black swallowtail, 1 honey bee \\
\hline \multirow[t]{8}{*}{ 9B } & Survey 1 Species & $9 B$ & Survey 1 Species \\
\hline & & & 2 brown duskywings \\
\hline & Survey 2 Species & & Survey 2 Species \\
\hline & little wood satyr & & \\
\hline & Survey 3 Species & & Survey 3 Species \\
\hline & fritillary & & 1 wood nymph, 1 least skipper, 1 ETB \\
\hline & Survey 4 Species & & Survey 4 Species \\
\hline & monarch, black swallowtail, bee & & \\
\hline \multirow[t]{7}{*}{$10 \mathrm{~B}$} & $\begin{array}{l}\text { Survey } 1 \text { Species } \\
\text { american lady, bee }\end{array}$ & $10 \mathrm{~B}$ & Survey 1 Species \\
\hline & Survey 2 Species & & Survey 2 Species \\
\hline & & & 1 duskywing \\
\hline & Survey 3 Species & & Survey 3 Species \\
\hline & skipper, common buckeye, monarch & & $\begin{array}{l}2 \text { monarch, } 22 \text { honey bee, } 6 \text { bee, } 2 \text { black swallowtail, } 2 \text { brown skipper, } \\
1 \text { fritillary, } 1 \text { yellow swallowtail, } 3 \text { ETB }\end{array}$ \\
\hline & Survey 4 Species & & Survey 4 Species \\
\hline & skipper, swallowtail, sulphur, black & & or 1 duckuving 1 hrown skinner \\
\hline \multirow{7}{*}{$11 \mathrm{~B}$} & $\begin{array}{l}\text { Swrvey } 1 \text { Species } \\
\text { Sullow, dee }\end{array}$ & $11 \mathrm{~B}$ & $\begin{array}{l}\text { Survey } 1 \text { Species } \\
\text { Suld }\end{array}$ \\
\hline & Survey 2 Species & & Survey 2 Species \\
\hline & skipper, little wood satyr, duskywing & & 2 wood satyr \\
\hline & Survey 3 Species & & Survey 3 Species \\
\hline & skipner common wood nvmph & & $\begin{array}{l}1 \text { yellow swallowtail, } 1 \text { black swallowtail, } 4 \text { wood nymph, } 2 \text { brown } \\
\text { skinper }\end{array}$ \\
\hline & Survey 4 Species & & Survey 4 Species \\
\hline & monarch & & 1 least skipper \\
\hline $12 \mathrm{~B}$ & Survey 1 Species & $12 \mathrm{~B}$ & Survey 1 Species \\
\hline
\end{tabular}


Survey 2 Species

blue spotted purple, skipper, little wood satyr Survey 3 Species

bee

Survey 4 Species

monarch, bee

13B Survey 1 Species

Survey 2 Species

little wood satyr, bee

Survey 3 Species

skipper, fritillary

Survey 4 Species

eastern tailed blue

14B Survey 1 Species

Survey 2 Species

Survey 3 Species

Survey 4 Species

painted lady, bee

17B Survey 1 Species

Survey 2 Species

Survey 3 Species

swallowtail, bee
Survey 2 Species

Survey 3 Species

5 bee, 1 ETB

Survey 4 Species

2 bee

13B Survey 1 Species

1 bumblebee

Survey 2 Species

2 wood nymph, 1 wood satyr

Survey 3 Species

2 wood nymph, 1 bee

Survey 4 Species

1 flower fly, 1 ETB, 1 wood nymph

14B Survey 1 Species

Survey 2 Species

1 least skipper

Survey 3 Species

Survey 4 Species

1 wood nymph, 1 bee

17B Survey 1 Species

Survey 2 Species

Survey 3 Species

10 bee, 4 med orange fritillary, 1 orange tree frog 


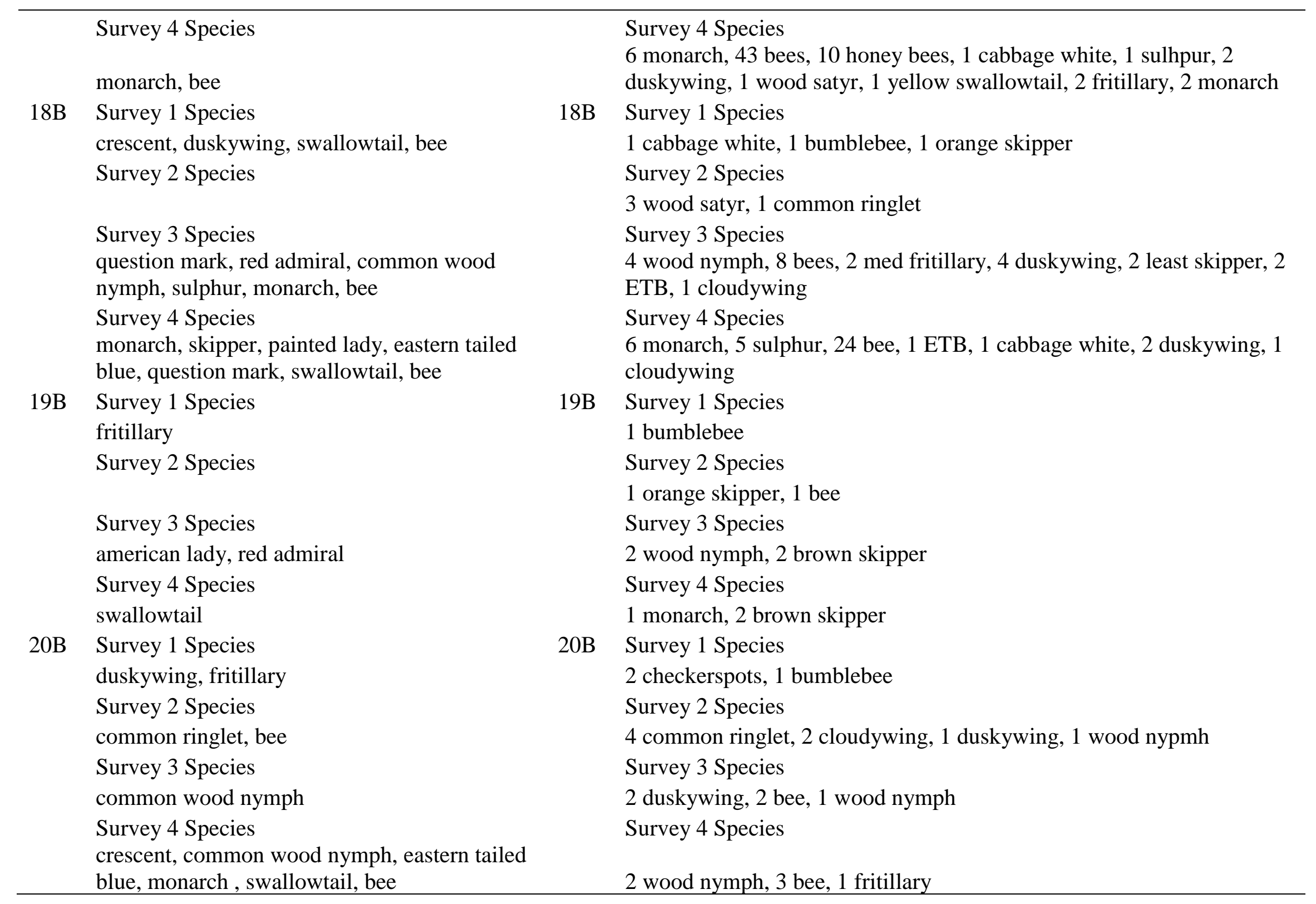




\begin{tabular}{|c|c|c|c|}
\hline \multirow[t]{6}{*}{$21 \mathrm{~B}$} & Survey 1 Species & $21 \mathrm{~B}$ & Survey 1 Species \\
\hline & & & 2 bumblebees \\
\hline & Survey 2 Species & & Survey 2 Species \\
\hline & & & 1 checkerspot \\
\hline & Survey 3 Species & & Survey 3 Species \\
\hline & $\begin{array}{l}\text { swallowtail, common wood nymph, monarch, } \\
\text { bee }\end{array}$ & & 3 monarch, 1 cabbage white, 1 wood nymph, 4 bee \\
\hline \multirow[t]{3}{*}{$22 \mathrm{~B}$} & $\begin{array}{l}\text { Survey } 1 \text { Species } \\
\text { azure spp. }\end{array}$ & $22 \mathrm{~B}$ & Survey 1 Species \\
\hline & Survey 2 Species & & Survey 2 Species \\
\hline & & & 2 wood satyr, 1 bumble bee \\
\hline \multirow[t]{8}{*}{$23 \mathrm{~B}$} & Survey 1 Species & 23B & Survey 1 Species \\
\hline & question mark & & 1 american lady, 1 duskywing \\
\hline & Survey 2 Species & & Survey 2 Species \\
\hline & & & 1 wood nymph, 1 sweat bee \\
\hline & Survey 3 Species & & Survey 3 Species \\
\hline & skipper, monarch & & 1 wood nymph, 1 least skipper \\
\hline & $\begin{array}{l}\text { Survey } 4 \text { Species } \\
\text { swallowtail, fritillary, monarch, black }\end{array}$ & & Survey 4 Species \\
\hline & swallowtail, bee & & 2 wood nymph, 2 ETB \\
\hline $24 \mathrm{~B}$ & Survey 1 Species & 24B & Survey 1 Species \\
\hline
\end{tabular}




\begin{tabular}{|c|c|c|c|}
\hline & Survey 3 Species & & $\begin{array}{l}1 \text { fritillary } \\
\text { Survey } 3 \text { Species } \\
2 \text { wood nymph }\end{array}$ \\
\hline & $\begin{array}{l}\text { Survey } 4 \text { Species } \\
\text { monarch, skipper }\end{array}$ & & Survey 4 Species \\
\hline \multirow[t]{6}{*}{$25 \mathrm{~B}$} & Survey 1 Species & 25B & Survey 1 Species \\
\hline & Survey 2 Species & & Survey 2 Species \\
\hline & Survey 3 Species & & Survey 3 Species \\
\hline & red admiral & & 5 med orange fritillary, 3 wood nymph, 1 monarch \\
\hline & Survey 4 Species & & Survey 4 Species \\
\hline & monarch, bee & & 2 bee, 1 monarch \\
\hline \multirow[t]{8}{*}{$26 \mathrm{~B}$} & Survey 1 Species & 26B & Survey 1 Species \\
\hline & & & 1 bumble bee, 2 cloudywings \\
\hline & Survey 2 Species & & Survey 2 Species \\
\hline & & & 3 cloudywing, 1 wasp \\
\hline & Survey 3 Species & & Survey 3 Species \\
\hline & $\begin{array}{l}\text { monarch, skipper, painted lady, common wood } \\
\text { nymph, checkerspot, bee }\end{array}$ & & 4 honey bee, 1 wood nymph, 1 checkerspot, 2 least skipper, 3 bee \\
\hline & Survey 4 Species & & Survey 4 Species \\
\hline & crescent, monarch, bee & & 2 checkerspot, 1 wood nymph, 2 fritillary, 2 bee, 2 monarch \\
\hline \multirow[t]{7}{*}{ 27B } & Survey 1 Species & 27B & Survey 1 Species \\
\hline & duskwing, fritillary, skipper, bee & & \\
\hline & Survey 2 Species & & Survey 2 Species \\
\hline & swallowtail & & \\
\hline & Survey 3 Species & & Survey 3 Species \\
\hline & nymph, swallowtail & & 3 wood nymph, 1 med orange fritillary \\
\hline & Survey 4 Species & & Survey 4 Species \\
\hline
\end{tabular}




\begin{tabular}{|c|c|c|c|}
\hline \multirow{4}{*}{$28 \mathrm{~B}$} & skipper, bee & \multirow{4}{*}{$28 B$} & \\
\hline & Survey 1 Species & & Survey 1 Species \\
\hline & & & 1 duskywing sp. \\
\hline & Survey 2 Species & & Survey 2 Species \\
\hline \multirow{6}{*}{$29 B$} & Survey 3 Species & \multirow{6}{*}{ 29B } & Survey 3 Species \\
\hline & skipper, bee & & \\
\hline & Survey 4 Species & & Survey 4 Species \\
\hline & monarch, swallowtail, black swallowtail, bee & & 2 bee, 1 wood nymph \\
\hline & Survey 1 Species & & Survey 1 Species \\
\hline & Survey 2 Species & & Survey 2 Species \\
\hline \multirow{10}{*}{ 30B } & Survey 3 Species & \multirow{15}{*}{$30 \mathrm{~B}$} & Survey 3 Species \\
\hline & swallowtail, black swallowtail, skipper, bee & & 1 duskywing \\
\hline & Survey 4 Species & & Survey 4 Species \\
\hline & $\begin{array}{l}\text { black swallowtail, common wood nymph, } \\
\text { swallowtail, cabbage white, sulphur, azure spp. }\end{array}$ & & 1 fritillary, 1 least skipper, 1 bee \\
\hline & Survey 1 Species & & Survey 1 Species \\
\hline & & & 1 bumblebee \\
\hline & Survey 2 Species & & Survey 2 Species \\
\hline & & & 1 bumblebee, 1 cloudywing, 1 purple swallowtail \\
\hline & Survey 3 Species & & Survey 3 Species \\
\hline & skipper, monarch, painted lady, bee & & 1 least skipper, 1 wood nypmh, 1 bee, 1 orange fritillary \\
\hline \multirow{5}{*}{$31 \mathrm{~B}$} & Survey 4 Species & & Survey 4 Species \\
\hline & bee & & 3 bee, 1 wood nymph, 1 monarch \\
\hline & Survey 1 Species & & Survey 1 Species \\
\hline & little wood satyr, fritillary & & 1 cloudy wing, 1 bumblebee \\
\hline & Survey 2 Species & & Survey 2 Species \\
\hline
\end{tabular}




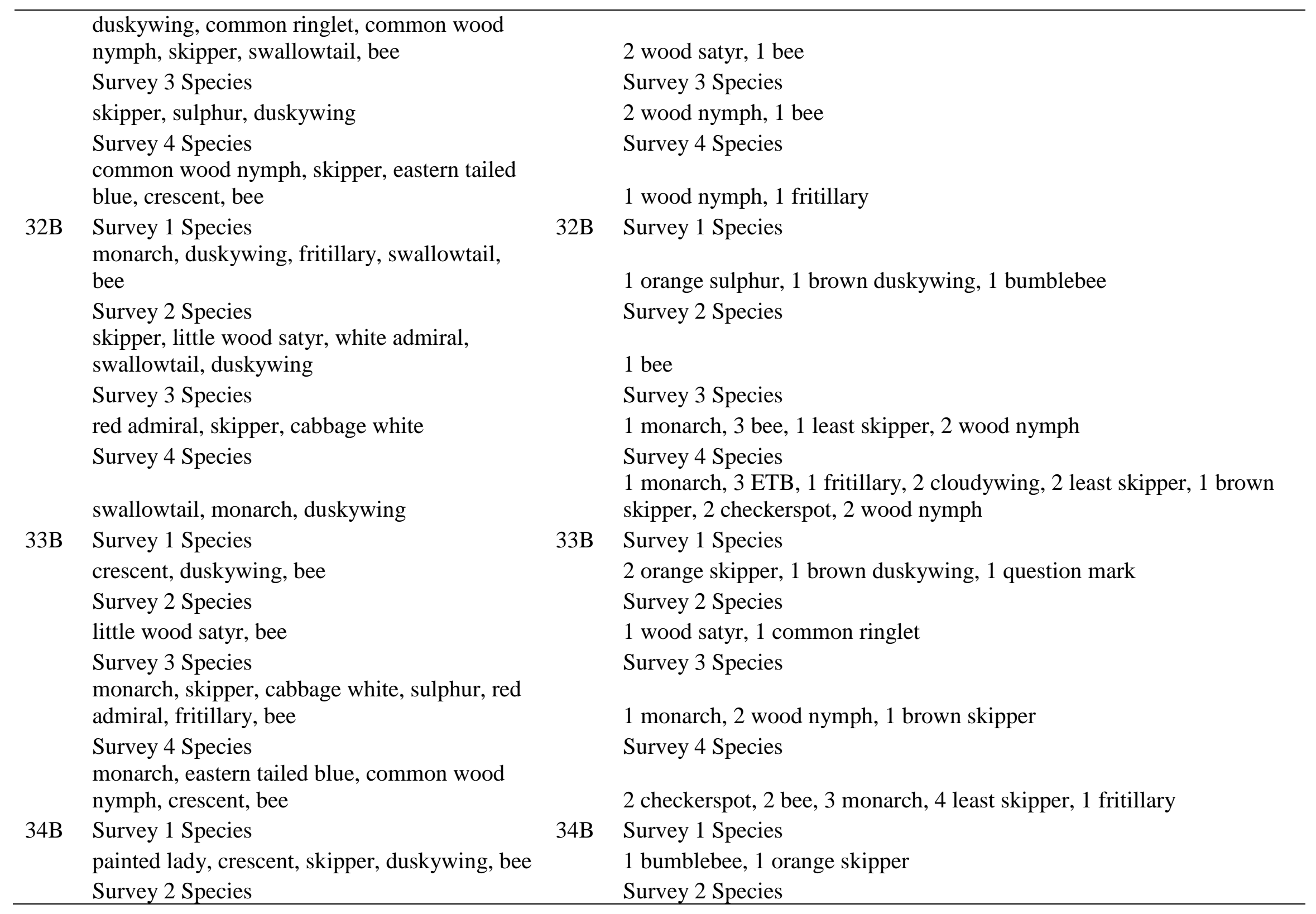




\begin{tabular}{|c|c|c|c|}
\hline \multirow{11}{*}{$35 \mathrm{~B}$} & & & black swallowtail \\
\hline & Survey 3 Species & & Survey 3 Species \\
\hline & skipper, monarch, red admiral, fritillary & & 2 least skipper, 3 fritillary, 1 wood nymph \\
\hline & Survey 4 Species & & Survey 4 Species \\
\hline & azure spp., monarch & & 2 checkerspot, 3 monarch, 1 least skipper, 1 wood nymph, 1 duskywing \\
\hline & $\begin{array}{l}\text { Survey } 1 \text { Species } \\
\text { duskywing }\end{array}$ & $35 \mathrm{~B}$ & Survey 1 Species \\
\hline & Survey 2 Species & & Survey 2 Species \\
\hline & question mark & & 1 common ringlet, 1 bumblebee \\
\hline & Survey 3 Species & & Survey 3 Species \\
\hline & red admiral & & 2 bee, 2 wood nymph, 1 least skipper \\
\hline & Survey 4 Species & & Survey 4 Species \\
\hline \multirow{4}{*}{ 36B } & eastern tailed blue, duskywing & & 2 wood nymph, 3 bee, 1 ETB \\
\hline & Survey 1 Species & $36 \mathrm{~B}$ & Survey 1 Species \\
\hline & & & 3 fritillary \\
\hline & Survey 2 Species & & Survey 2 Species \\
\hline \multirow{11}{*}{$37 \mathrm{~B}$} & & & 1 sulphur, 1 duskywing \\
\hline & Survey 3 Species & & Survey 3 Species \\
\hline & skipper, red admiral, cabbage white, bee & & 1 med orange fritillary \\
\hline & Survey 4 Species & & Survey 4 Species \\
\hline & eastern tailed blue, duskywing & & $\begin{array}{l}1 \text { black swallowtail, } 1 \text { brown skipper, } 3 \text { ETB, } 1 \text { orange skipper, } 2 \text { bee, } 2 \\
\text { sulphur }\end{array}$ \\
\hline & Survey 1 Species & 37B & Survey 1 Species \\
\hline & Survey 2 Species & & Survey 2 Species \\
\hline & & & 1 wood satyr, 1 common ringlet \\
\hline & Survey 3 Species & & Survey 3 Species \\
\hline & red admiral & & 1 least skipper, 1 black swallowtail \\
\hline & Survey 4 Species & & Survey 4 Species \\
\hline
\end{tabular}




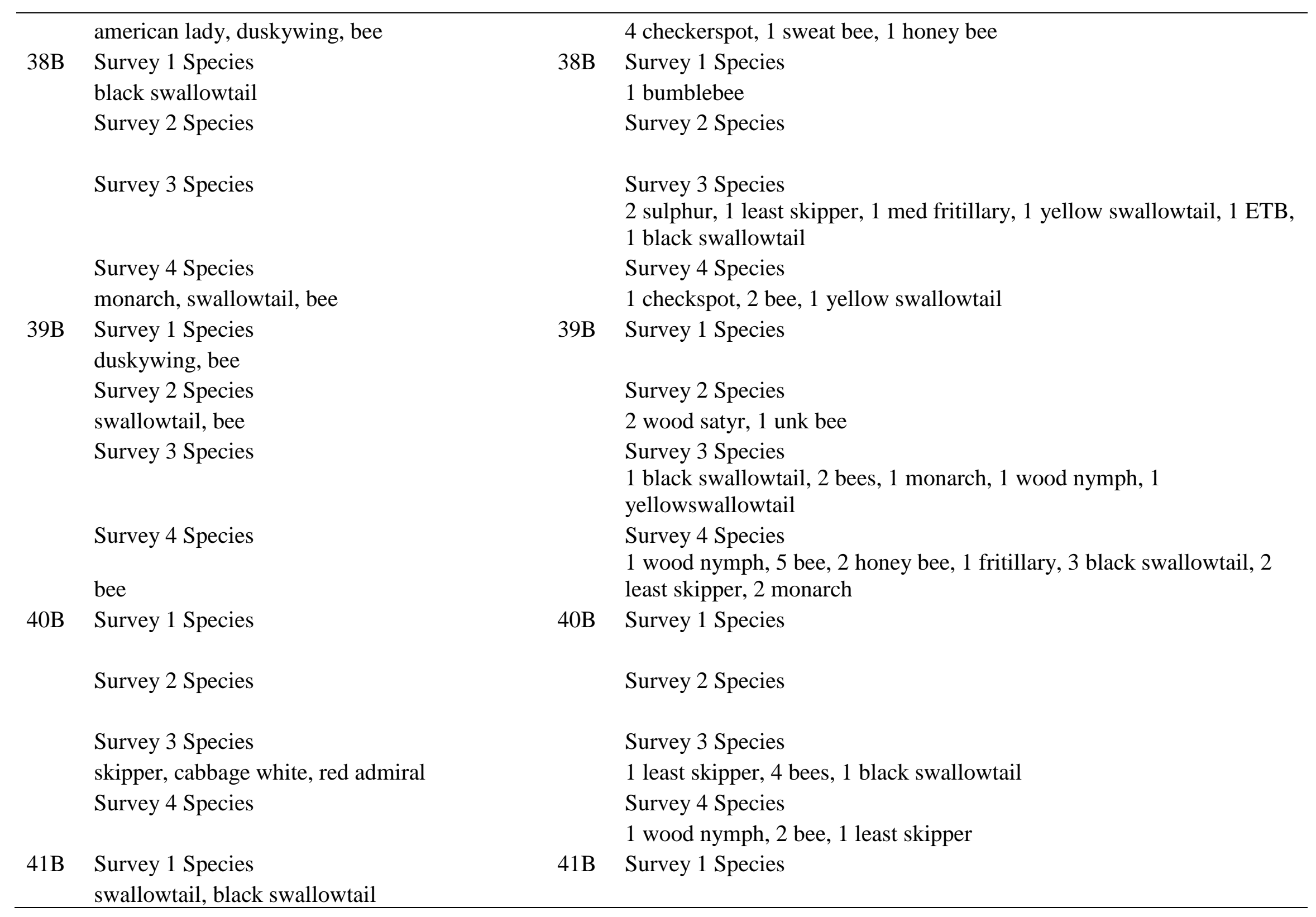




\begin{tabular}{|c|c|c|c|}
\hline & Survey 2 Species & & Survey 2 Species \\
\hline & Survey 3 Species & & Survey 3 Species \\
\hline & red admiral, skipper, swallowtail & & 2 least skipper, 1 bee \\
\hline & Survey 4 Species & & Survey 4 Species \\
\hline & & & 2 fritillary, 1 monarch, 2 bee \\
\hline \multirow[t]{5}{*}{$42 \mathrm{~B}$} & Survey 1 Species & $42 \mathrm{~B}$ & Survey 1 Species \\
\hline & Survey 3 Species & & Survey 3 Species \\
\hline & & & 2 least skipper \\
\hline & Survey 4 Species & & Survey 4 Species \\
\hline & bee & & 1 yellow swallowtail, 1 wood nymph \\
\hline
\end{tabular}

